Caique Fernandes de Souza

Validação do envolvimento dos genes KRT6A, KRT19, MSLN e KLK8 por RT-PCR quantitativa em tempo real em carcinomas epidermóides de cabeça e pescoço

Expression analysis of $K R T 6 A, K R T 19, M S L N$ and $K L K 8$ genes by quantitative real time RT-PCR in head and neck squamous cell carcinomas 
Caique Fernandes de Souza

Validação do envolvimento dos genes KRT6A, KRT19, MSLN e KLK8 por RT-PCR quantitativa em tempo real em carcinomas epidermóides de cabeça e pescoço

Expression analysis of $K R T 6 A, K R T 19, M S L N$ and $K L K 8$ genes by quantitative real time RT-PCR in head and neck squamous cell carcinomas

Dissertação apresentada ao Instituto de Biociências da Universidade de São Paulo, para a obtenção de Título de Mestre em Ciências, na Área de Biologia/Genética.

Orientadora: Eloiza Helena Tajara da Silva 
Fernandes de Souza, Caique

Validação do envolvimento dos gene KRT6A, KRT19, MSLN e KLK8 por RT-PCR quantitativa em tempo real em carcinomas epidermódes de cabeça e pescoço

113 páginas

Dissertação (Mestrado) - Instituto de Biociências da Universidade de São Paulo. Departamento de Genética e Biologia Evolutiva.

1. Expressão gênica. 2. Carcinomas epidermóides de cabeça e pescoço.

Universidade de São Paulo. Instituto de Biociências. Departamento de Genética e Biologia Evolutiva.

\section{Comissão Julgadora:}

$\operatorname{Prof}(\mathrm{a}) . \operatorname{Dr}(\mathrm{a})$.

Prof(a). Dr(a).

Profa. Dra. Eloiza Helena Tajara da SIlva

Orientadora 
À Deus

À minha família

Ao meu avô Benedito (in memorian) 
"Um homem precisa viajar. Por sua conta, não por meio de histórias, imagens, livros ou TV. Precisa viajar por si, com seus olhos e pés, para entender o que é seu. Para um dia plantar as suas próprias árvores e dar-lhes valor. Conhecer o frio para desfrutar o calor. E o oposto. Sentir a distância e o desabrigo para estar bem sob o próprio teto. Um homem precisa viajar para lugares que não conhece para quebrar essa arrogância que nos faz ver o mundo como o imaginamos, e não simplesmente como é ou pode ser. Que nos faz professores e doutores do que não vimos, quando deveríamos ser alunos, e simplesmente ir ver."

(Amyr Klink) 


\section{Agradecimentos}

À minha orientadora, Eloiza Helena Tajara da Silva, por me aceitar como orientado e acreditar em mim. Sempre esteve presente nos momentos de dificuldade, mostranto todos os caminhos possíveis para superá-los. Sua sabedoria, paciência e dedicação são um exemplo para todos. Muito obrigado por essa oportunidade!

Ao Instituto de Biociências da Universidade de São Paulo - IB/USP, por me propiciar uma excelente formação científica.

Aos coordenadores e funcionários do programa de Pós-graduação em Genética do Instituto de Biociências da USP, e em especial a Deisy Santos de Morais, pela competência e disposição, auxiliando sempre que necessário.

À Faculdade de Medicina de São José do Rio Preto (FAMERP), por oferecer a estrutura necessária para realizar esse trabalho.

Aos pesquisadores do grupo GENCAPO (Head and Neck Genome Project), responsáveis pela coleta das amostras biológicas e respectivas análises patológicas, além de disponibilizarem os dados dos pacientes.

Ao Dr. Breno Gutierrez Motta, por gentilmente ceder as amostras de cavidade oral normais para o cultivo de queratinócitos.

Aos pacientes, que voluntariamente doaram as amostras para a pesquisa científica.

Aos amigos do Laboratório de Marcadores Moleculares e Bionformática Médica (LMMBM) pela amizade, carinho, vivência, compreensão. Agradeço à Flávia, Ulises, Flávio, Tiago, Rodrigo, Giovana, Fernanda, Bianca, Natália, Juliana, Jaqueline e Alessandra.

À FAPESP (Fundação de Amparo à Pesquisa Científica do Estado de São Paulo) e ao CNPq (Conselho Nacional de Desenvolvimento Científico e Tecnológico), pelo auxílio financeiro.

Aos meus grandes amigos Pierre, Felipe Knappe e Shester Carlos, por sempre estarem ao meu lado nos momentos bons e ruins.

Aos meus pais Luiz Carlos de Souza e Telma Sumara Fernandes das Neves de Souza por todo o cuidado, carinho, dedicação, compreensão e amor com que me criaram. Agradeço por toda a vida pelos ensinamentos e conselhos, pela palavra amiga que vocês me deram nos momentos difíceis e pela ajuda para tomar as decisões em minha vida. EU AMO VOCÊS!

À minha avó Rosa Kantowitz de Souza e a minha tia Maria Magdalena de Souza por todo apoio que me deram e fizeram com que fosse possível a concretização de mais essa etapa em minha vida. 
Sumário

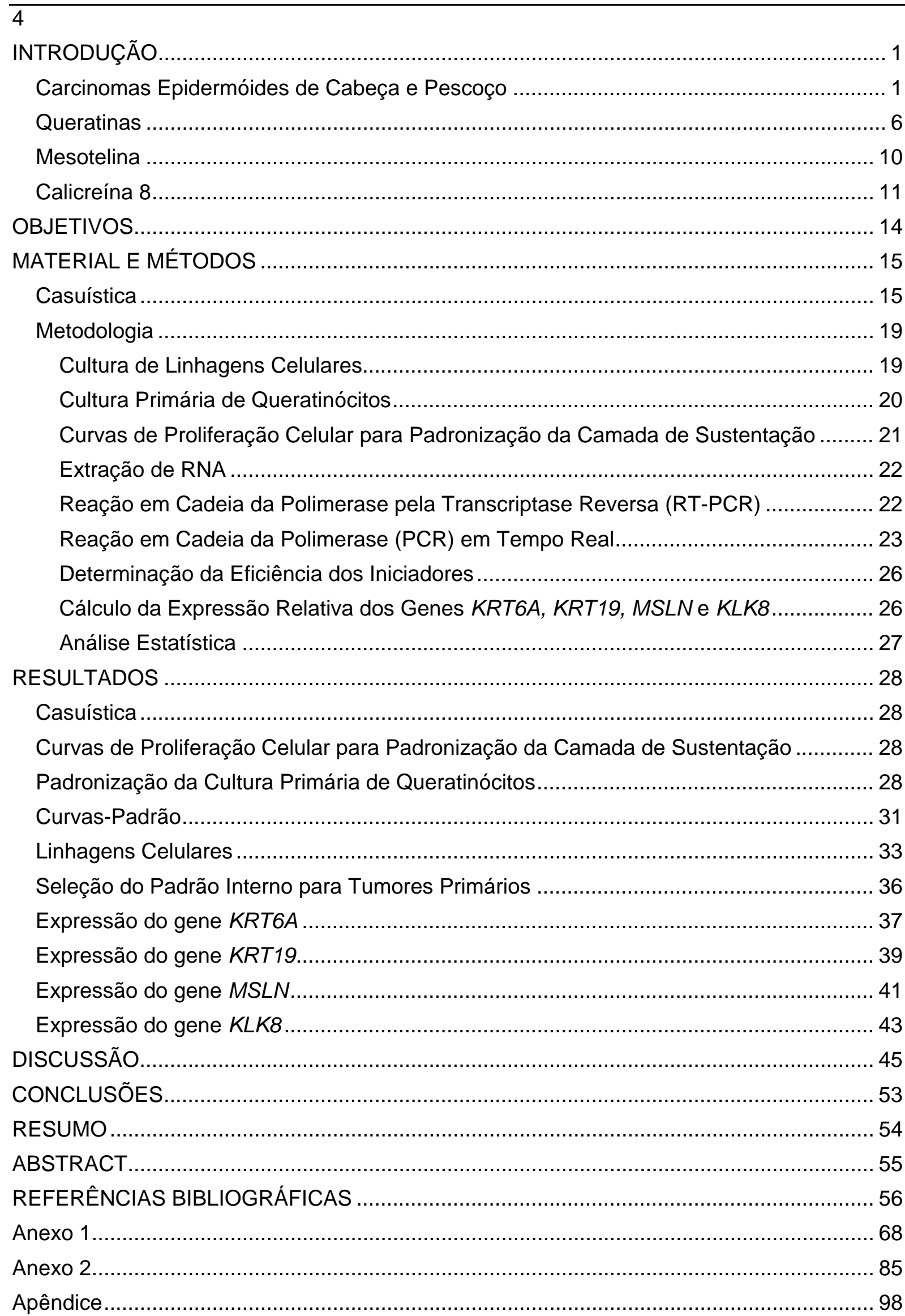




\section{INTRODUÇÃO}

\section{Carcinomas Epidermóides de Cabeça e Pescoço}

Os tumores de cabeça e pescoço compreendem processos malignos que ocorrem em uma variedade de sítios do trato aéreo-digestivo superior, incluindo cavidade oral, orofaringe, hipofaringe e laringe. O tipo histológico mais comum é o carcinoma de células escamosas ou epidermóide (CECP). Esses carcinomas são clinicamente heterogêneos e resultam do acúmulo de mutações somáticas em genes que regulam o crescimento, a proliferação e a morte celular, consequentemente levando a alterações na função dos seus produtos (Ha et al., 2009). Existem evidências de que mudanças epigenéticas também estão relacionadas com a tumorigênese de cabeça e pescoço porque podem conferir vantagens proliferativas para a célula (Calmon et al., 2009).

É estimada uma incidência anual de aproximadamente 500 mil novos casos de CECP no mundo e aproximadamente 300 mil óbitos (Globocan 2002, http://www-dep.iarc.frl; Parkin et al., 2005). Apesar da incidência elevada em alguns países desenvolvidos, como a França (Moriniere, 2006), a taxa de mortalidade é menor do que em países em desenvolvimento (Ferlay et al., 2002). Esse fato é dependente do sub-sítio anatômico afetado, que por sua vez está relacionado com fatores etiológicos regionais (Parkin et al., 2005). Em alguns países, como nos Estados Unidos, a incidência de CECP da maioria dos subsítios está decrescendo gradualmente, comparando-se os dados de 1975 a 2007 (Altekruse et al., 2009), provavelmente em decorrência de diagnósticos mais precoces. No Brasil, são esperados cerca de 14 mil novos casos em 2010, considerando somente os de cavidade oral (Ministério da Saúde, 2009), o que representa a maior taxa de incidência desse subgrupo em países com renda média-alta (Cancela et al., 2009).

Os CECPs compreendem um importante problema de saúde pública porque aumentam significantemente a morbidade e a mortalidade dos afetados (Gilbert, 2008). A taxa geral de sobrevida de 5 anos para os pacientes está entre as mais baixas quando comparada a outros tipos de câncer (Dasgupta et al., 2006), apesar do progresso significativo que ocorreu nos últimos anos em diagnóstico, tratamento local e regimes terapêuticos direcionados para essa doença.

A etiologia dos carcinomas de cabeça e pescoço é complexa, mas os fatores de risco principais são o uso de tabaco e o consumo de álcool (Hunter et al., 2005; Hashibe et al., 2009). Rodriguez e colaboradores (2004) verificaram um valor de odds ratio (OR) de 20,7 para câncer de cavidade oral e faringe em fumantes com consumo superior a 25 cigarros/dia. Os autores também encontraram valores OR entre 1 e 5 para etilistas, proporcional à quantidade de álcool consumida. O efeito combinado dos dois fatores 
resultou em um aumento na OR de cerca de 48 vezes, diretamente relacionado ao nível de tabaco e álcool. Uma conclusão similar foi obtida por Hashibe et al. (2009).

O risco de câncer de cavidade oral também é elevado para outros tipos de tabagismo. Em comunidades da Índia e Indonésia, por exemplo, onde a população masca "betel quid", tabaco e sementes do betel (Areca catechu) embrulhados na folha do betel, a incidência desse câncer está elevada (revisto por Hunter et al., 2005).

A interrupção do hábito de fumar mostra uma importante redução de riscos de tumores de cabeça e pescoço e de outros tumores do trato aerodigestivo superior, com valores cumulativos aos 75 anos iguais a 6,3\% para controles fumantes, e 3,1\% ou 1,2\% para aqueles que pararam de fumar aos 50 ou aos 30 anos de idade, respectivamente (Bosetti et al., 2008; Marron, 2010).

Os carcinógenos produzidos pelo tabaco, como o benzo(a)pireno e as nitrosaminas, produzem tipos característicos de transversão do nucleotídeo guanina em genes cruciais envolvidos no desenvolvimento dos CECPs, como o TP53 (Brennan et al., 1995). No caso do álcool, a carcinogênese de cabeça e pescoço parece ser mediada pelo seu produto de metabolização, o acetaldeído, que pode causar danos ao DNA (Balbo et al., 2008) e seqüestrar glutationa, um peptídeo importante na destoxicação de carcinógenos. O álcool também pode induzir a enzima CYP2E1, que está envolvida na ativação de vários prócarcinógenos encontrados em bebidas alcoólicas e no tabaco (revisto por Hunter et al., 2005).

Zhang e colaboradores (1999) verificaram um aumento do risco de desenvolvimento de câncer de cabeça e pescoço em usuários de maconha (Cannabis sativa), com uma relação dose-resposta para freqüência e duração. Essa associação foi independente de idade, sexo, raça, educação, consumo de álcool e fumo. Resultados contrários a esses foram relatados por vários autores, avaliando diferentes sub-sítios anatômicos (Llewellyn et al., 2004; Rosenblatt et al., 2004; Hashibe et al., 2006; Aldington et al., 2008). O consórcio

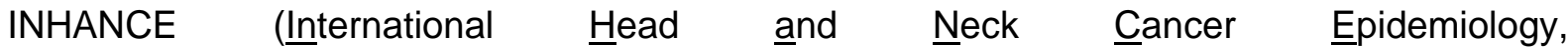
http://inhance.iarc.fr/studies.php), coordenado pela Agência Internacional de Pesquisas em Câncer (International Agency for Research on Cancer - IARC), fez uma revisão de 18 estudos individuais do tipo caso-controle em câncer de cabeça e pescoço, dos quais cinco continham informações sobre o uso de maconha. Com um total de 4085 pacientes e 5125 controles, a análise agrupada dos casos também não detectou uma associação significativa entre o consumo freqüente de maconha e o risco desse câncer (Berthiller et al., 2009).

Em relação a outros fatores de risco, os dados da literatura indicam o envolvimento do papilomavírus humano (HPV) na etiologia dos CECPs, primeiramente proposto por Syrjanen et al. (1983) e recentemente confirmado por vários trabalhos (Herrero et al., 2003; Smith et al., 2004; Kreimer et al., 2005; D'Souza et al., 2007), especialmente para os tumores de 
orofaringe. Os CECPs HPV-positivos aparentemente formam um grupo à parte dos demais CECPS, com menores taxas de recorrência e maior sobrevida (Smith et al., 2008; Lassen et al., 2009; Sedaghat et al., 2009).

A transformação maligna das células epiteliais da cavidade oral por HPVs oncogênicos ou de alto risco, como os tipos 16 e 18, depende da atuação de suas proteínas E6 e E7 (Chow et al., 2010). A oncoproteína E6 interage com a supressora tumoral p53 e dirige sua degradação mediada pelo proteassomo, recrutando a ligase E6AP. Da mesma forma, a oncoproteína E7 liga-se e promove a degradação da proteína retinoblastoma (pRb), impedindo sua interação com o fator de transcrição E2F e, portanto, promovendo a progressão do ciclo celular (Pim et al., 2009; Chow et al., 2010; Pim e Banks, 2010). Assinaturas genéticas de carcinomas epidermóides de orofaringe mostraram-se diferentes quando comparados tumores HPV-positivos e HPV-negativos, além de alterações cromossômicas distintas entre os dois tipos, refletindo possíveis diferenças do desenvolvimento e da progressão do tumor (Klussmann et al., 2009).

Uma associação positiva com risco de CECP foi também encontrada para má higiene bucal e perda de dentes, independentemente do consumo de álcool ou tabaco (Guha et al., 2007; Hiraki et al., 2008), o que sugere a ligação de infecções bacterianas crônicas com a patogênese desse câncer (Curado e Hashibe, 2009). Em relação à dieta, assim como ocorre para outros tipos de tumor, foi observada uma associação inversa entre o total de frutas e vegetais ingeridos e o risco da doença (Boeing et al., 2006; Freedman et al., 2008; Sapkota et al., 2008).

Outros fatores de risco para carcinomas de cabeça e pescoço incluem polimorfismos em enzimas que metabolizam tabaco e álcool (Hashibe et al., 2006; Sturgis e Wei, 2002), história familial (Suarez et al., 2006; Negri et al., 2009) e síndromes de susceptibilidade ao câncer, como Li-Fraumeni, Lynch-II, anemia de Fanconi e ataxia telangectasia (Trizna e Schantz, 1992; Foulks et al., 1996).

Atualmente, algumas variáveis clinicopatológicas são utilizadas para prognóstico de pacientes com CECP, como tamanho do tumor ao diagnóstico, presença de metástases em linfonodos e grau de diferenciação da lesão, o que é frequentemente insuficiente para predizer desfecho clínico. Tem sido sugerido que o status da margem cirúrgica, geralmente avaliado por análise histológica, pode ter também valor prognóstico, tanto para recorrência como para metástase à distância (Martone et al., 2007). Entretanto, a recorrência local pode ser observada em pacientes com margens negativas, reforçando a hipótese proposta por Slaughter e colaboradores (1953) de cancerização de campo e de tecido histologicamente alterado ao redor do carcinoma como causa de falha no tratamento.

As decisões sobre tratamento em CECP são geralmente complexas e dependem de vários especialistas, incluindo cirurgiões de cabeça e pescoço e cirurgiões plásticos, 
oncologistas, radiologistas e dentistas. O sítio primário do tumor, seu estadiamento e outros fatores, como preservação do órgão e da deglutição, são utilizados para guiar a escolha da melhor conduta que, em geral, envolve cirurgia e radioterapia (Argiris et al., 2008).

Recentemente, alguns marcadores derivados de análises moleculares têm sido identificados e empregados com benefícios clínicos, como os inibidores do receptor de fator de crescimento epidérmico (EGFR) (Karamouzis et al., 2007; Argiris et al., 2008). As mudanças no perfil de expressão gênica são potencialmente úteis para detecção precoce e avaliação de agressividade (Hunter et al., 2005) e, se identificadas na fase pré-operatória, também para definição de um tratamento apropriado para o paciente (Gollin, 2001). Entretanto, poucos marcadores moleculares são conhecidos que apresentam características de sensibilidade e especificidade para diagnóstico ou prognóstico em CECP. O entendimento das vias moleculares envolvidas na iniciação e na progressão desses tumores é, portanto, muito importante para o conhecimento de sua biologia e, consequentemente, para o desenvolvimento de abordagens preventivas e terapêuticas eficazes.

Sob uma perspectiva genética, a progressão dos carcinomas de cabeça e pescoço tem sido descrita com alterações e padrões específicos que levam à transformação maligna (Ha et al., 2003). O modelo mais conhecido foi proposto por Califano e colaboradores (1996) e inclui inativação de genes supressores de tumor e ativação de proto-oncogenes, que ocorrem durante o desenvolvimento do processo neoplásico, desde lesões hiperplásicas benignas até displasia, carcinoma in situ e carcinoma invasivo. Os estudos moleculares têm continuamente acrescentado novos elementos ao modelo de Califano, incluindo mudanças epigenéticas e do microambiente tumoral (Argiris et al., 2008) (Figura 1).

Entre as principais alterações que ocorrem na transformação da mucosa normal, está a reativação da telomerase, uma ribozima envolvida na manutenção dos telômeros e na imortalização das células, descrita em $90 \%$ dos casos de CECP e em lesões pré-malignas (McCaul et al., 2002). A perda de segmentos das regiões cromossômicas 9p21 bem como a perda de $3 p$, as mutações de ponto no gene TP53 e a inativação do gene CDKN2A (p16/p14), por deleção homozigótica, mutações de ponto ou metilação do promotor, compreendem os eventos precoces da tumorigênese de cabeça e pescoço (Mao et al., 1996; Rocco e Sidransky, 2001; Balz et al., 2003; Perez-Ordenez et al., 2006). As amplificações da banda 11q13 na forma de regiões homogeneamente coradas e o aumento de expressão da ciclina D1 também são detectados em CECP e têm sido correlacionados com um comportamento tumoral mais agressivo (Pignataro et al., 1998; Capaccio et al., 2000; Martin et al., 2008). 


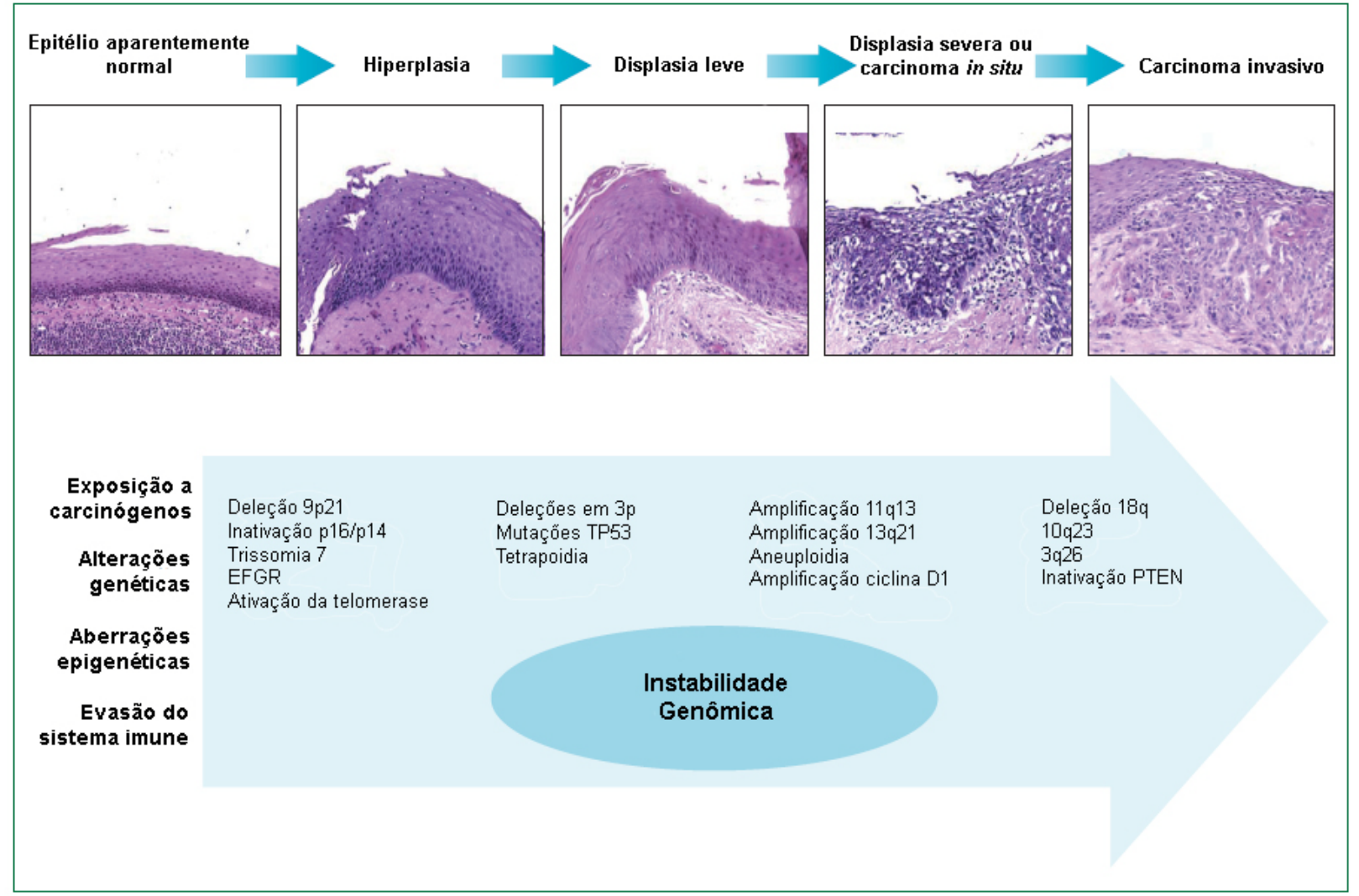

Figura 1. Evolução fenotípica e alterações moleculares que ocorrem na tumorigênese de cabeça e pescoço, segundo revisão de Argiris et al. (2008). 
O aumento de expressão da proteína EGFR, observado em $90 \%$ ou mais dos casos de CECP, está associado com pior prognóstico (Rubin et al., 1998). Esse receptor inicia uma cascata de sinalização após interação com seu ligante e consequente dimerização, e ativa vias que regulam proliferação celular, apoptose, invasão e angiogênese (Karamouzis et al., 2007). Mais recentemente, surgiram evidências de que alguns microRNAs, entre eles mir21, miR-184, miR-133a/133b, miR-137, and miR-193a, participam do desenvolvimento de CECPs, atuando em processos celulares como diferenciação, proliferação e apoptose (Chang et al., 2008; Liu et al., 2009). Essas pequenas moléculas de RNA de aproximadamente 22 nucleotídeos regulam a expressão gênica pós-transcricional ligando-se à região 3' não traduzida de mRNAs alvos e, quando em níveis alterados, podem afetar diferentes vias de sinalização.

Como pode ser deduzido do exposto acima, os tumores de cabeça e pescoço exibem muitas alterações genéticas. Várias técnicas de análise de amplo alcance têm fornecido uma lista crescente de biomarcadores potenciais. Entre essas técnicas, estão a de microarray de cDNA e de análise serial de expressão gênica (SAGE), ambas capazes de analisar a expressão de milhares de genes simultaneamente.

Os dados de microarrays utilizando amostras de CECP têm revelado muitas alterações que permitem, por exemplo, distinguir tumores metastáticos de não-metastáticos (Roepman et al., 2005) e revelar um perfil distinto mesmo entre lesões de subsítios muito próximos (Severino et al., 2008). Esses resultados podem auxiliar a escolha de um tratamento adequado para os pacientes, assim como antecipar a progressão da doença.

Em um estudo prévio de nosso grupo, Silveira et al. (2008) avaliaram dados de SAGE em carcinomas de laringe com o objetivo de identificar eventos envolvidos no desenvolvimento de CECPs. Foram construídas duas bibliotecas, uma a partir de tumor com mestástase em linfonodos regionais e outra de tumor sem evidência de metástases, além de uma biblioteca gerada de um pool de amostras de margens cirúrgicas. Sua análise estatística de aproximadamente 54 mil tags revelou conjuntos de tags diferencialmente expressas em tumor versus tecido normal e em carcinoma metastático versus não metastático. Entre os 60 genes com valores mais discriminativos, estavam os das queratinas 6A (KRT6A) e 19 (KRT19), da mesotelina (MSLN) e da calicreína 8 (KLK8).

\section{Queratinas}

As queratinas são proteínas do grupo dos filamentos intermediários presentes nas células epiteliais de vertebrados (revisto por Bragulla e Homberger, 2009). As análises genômicas recentes têm revelado 13 pseudogenes e 54 genes funcionais das queratinas, 28 do tipo I ou acídicas (K9-K23) e 26 do tipo II ou básico-neutras (K1-K8), mapeados em duas regiões cromossômicas 17q21.2 e 12q13.13, respectivamente, com exceção do gene 
da K18 que está localizado no cromossomo 12 (Schweizer et al. 2006). A unidade mais simples dessas proteínas é um tetrâmero com dois dímeros antiparalelos; cada dímero formado por uma molécula de queratina do tipo I e uma do tipo II (Figura 2).

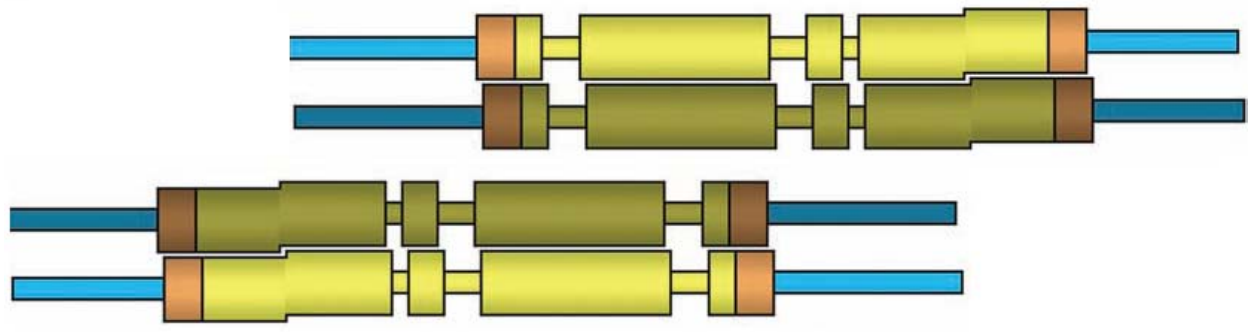

Figura 2. Esquema da molécula de queratina mostrando o alinhamento de heterodímeros I / II e a formação de tetrâmeros (modificado de Bragulla e Homberger, 2009).

As 54 queratinas são divididas em duas categorias, as epiteliais e as queratinas de cabelo (Schweizer et al., 2006). Sua função está relacionada com manutenção da estrutura epitelial, proteção contra traumas mecânicos e, possivelmente, comunicação entre células adjacentes ou componentes do citoplasma (Ishida-Yamamoto et. al., 2002; Oshima, 2002).

Magin et al. (2007) também propuseram uma função regulatória para as citoqueratinas, bem como seu envolvimento em vários aspectos do comportamento celular, como migração, diferenciação e proliferação. Seus argumentos se baseiam no fato de que a reorganização dos filamentos intermediários de queratina em resposta a sinais extra e intracelulares depende de sua fosforilação em resíduos de serina, o que resulta na geração de grânulos e aumento de um pool solúvel de oligômeros. Essa fosforilação cria ao mesmo tempo sítios de ligação para as proteínas adaptadoras 14-3-3 (Ku et al., 1998) que, dependendo da queratina, leva à regulação de síntese protéica via cascata de mTOR (Kim et al., 2006) ou à progressão do ciclo celular (Margolis et al., 2006).

Uma ampla gama de doenças de epitélio tem sido associada com mutações nos genes das queratinas. Em geral essas doenças são causadas por mutações dominante-negativas, a maioria delas do tipo missense ou com pequenas deleções ou inserções que mudam a matriz de leitura, e são caracterizadas por fragilidade do tecido afetado e, em alguns casos, por hiperplasia (Omary et al., 2004).

Nas neoplasias, as queratinas possuem um papel importante em migração celular, invasão e metástase. Sua expressão alterada e/ou desequilíbrio do pareamento das queratinas do tipo I e II podem resultar em resistência a drogas, reparo tecidual deficiente, 
aumento de diferenciação e sobrevivência celular ou apoptose, além de ativação de vias de transdução de sinal responsáveis pela progressão da doença (Bambang et al., 2009).

Em condições de injúria, a transcrição dos genes das queratinas 6, 16 e 17 é induzida, enquanto a expressão do gene da queratina 10 é reduzida, provavelmente para garantir à célula um citoesqueleto que favoreça a migração para o local da lesão (Paladini et al., 1996; Wong e Coulombe, 2003). Os dados de Trost et al. (2010) adicionam uma informação importante a essa questão. Seu estudo concluiu que um desequilíbrio nas proporções do heterodímero K6/K16 reduz o potencial migratório dos queratinócitos bem como a capacidade de regeneração pós-injúria. Esse achado possui importantes implicações para o entendimento de processos de envelhecimento, que mostram perda dessa capacidade, e de doenças neoplásicas, nas quais a migração é uma característica de fenótipos agressivos.

Além de situações de injúria, as K6, K16 e K17 também são alteradas em várias doenças crônicas que afetam a pele, incluído psoríase, carcinomas, infecções, dano induzido por luz ultra-violeta e condições inflamatórias (Trost et al., 2010). Por exemplo, mutações nos genes das citoqueratinas 6a (KRT6A) ou 16 (PC tipo-1, OMIM 167200) e nas citoqueratinas 6b ou 17 (PC tipo-2, OMIM 167210) resultam na doença Paquioniquia Congenita (PC), um distúrbio genético bem caracterizado que afeta principalmente as unhas e a pele e cujos principais sintomas incluem unhas extremamente espessas e queratose palmoplantar (Smith et al., 2006). Recentemente, Hickerson et al. (2009) verificaram que a rampamicina inibe seletivamente o KRT6A em quaratinócitos humanos e promove uma melhoria nos sintomas dessa doença. De modo inverso, a interleucina-1 causa mudanças no citoesqueleto de queratinócitos epidermóides humanos por meio da indução de expressão da queratina 6 (Komine et al., 2001). O hormônio da tireóide T3 possui efeito similar e parece induzir a proliferação de queratinócitos e cicatrização, estimulando a expressão de K6A bem como de K16 e K17 (Safer et al., 2004).

A queratina 6 e seus parceiros K16 e 17 são observados em epitélio estratificado, tais como os de língua e pálato, bem como nas células suprabasais da epiderme plantar e palmar, da unha e da bainha externa do folículo piloso (Takahashi et al., 1995; Barak et al., 2004; Bragulla e Homberger, 2009). Existem três variantes da queratina 6, cada uma codificada por seu próprio gene: KRT6A, KRT6B e KRT6C, cujos RNAs são traduzidos em diferentes produtos por splicing alternativo e modificações pós-traducionais (Schweizer et al., 2006). A função da variante $6 \mathrm{~A}$, como pode ser deduzido do exposto acima, está relacionada com reparo e repopulação de queratinócitos (Van der Velden et al., 1999; Chou e Goldman, 2000). O estudo de Schmelz et al. (2005) sugere que células KRT6A+ de próstata são candidatas a células-tronco desse tecido.

Em câncer, já foi observada a redução de níveis das queratinas 5 e 6 (K5/6) em carcinomas perianais (Lisovsky et al. (2007). Em câncer de mama, por outro lado, sua 
expressão e/ou do receptor do fator de crescimento epidermal (EGFR) parece favorecer um pior prognóstico (Tischkowitz et al., 2007). No grupo de tumores de cabeça e pescoço, os dados são escassos. Entretanto, o papel das citoqueratina 6 nesses casos pode ser previsto considerando os resultados obtidos com camundongos $\mathrm{K} 6$ ou $\mathrm{K} 6 \mathrm{~A} / 6 \mathrm{~B}$ nulos, que mostram alterações específicas da mucosa oral (Wong et al., 2000; Wojcik et al., 2001).

Ao contrário da queratina 6, a K19 é expressa geralmente em epitélio simples, pseudo estratificado. Essa proteína forma filamentos intermediários com K8, K5 e K7 (revisto por Bragulla e Homberger, 2009). Na maioria dos tumores epiteliais, apresenta expressão elevada, como em carcinoma hepatocelular (Uenishi et al., 2003), câncer de mama (Parikh et al., 2008) e pulmão (Chen et al., 2007) e em tumores endócrinos pancreáticos (Schmitt et al., 2007).

Como algumas outras queratinas, a K19 pode ser liberada das células tumorais em diferentes fluidos corporais. Em indivíduos saudáveis, o nível de queratinas na circulação é baixo, ao contrário dos pacientes com carcinomas epiteliais (Barak et al., 2004). Em função dessa característica, a K19 ou seu RNA são utilizados como marcadores de micrometástases na medula óssea (Ozbas et al., 2003; Vincent-Salomon et al., 2007), na corrente sanguínea (Ignatiadis et al., 2007, 2008; Xenidis et al., 2006; Stathopoulou et al., 2002) e em linfonodos de pacientes com CECP (Xu et al., 2008) ou com outros carcinomas (Saintigny et al., 2005).

Essas células tumorais disseminadas podem sobreviver em um estado dormente por períodos prolongados, até que sejam reativadas e colonizem os órgãos alvo. Bambang et al. (2009) observaram que a queratina 19 é um importante modulador desse estado de dormência, capaz de reprogramar o ciclo celular e modular vias de sinalização e, portanto, de contribuir para a sobrevivência da célula tumoral.

Na mucosa oral normal ou hiperplásica, a K19 é somente detectada na camada basal (Zhong et al., 2007). Em carcinomas epidermóides de cavidade oral, sua presença é observada na mucosa com displasia ou no carcinoma in situ, tanto na camada basal como suprabasal (Lindberg et al., 1989). Uma ampla faixa de frequência desses tumores positivos para expressão da proteína é relatada na literatura, desde 29\% (Vora et al., 2003) ou 67\% (Hamakawa et al., 1998) dos carcinomas estudados até $100 \%$ de casos com marcação positiva (Nie et al., 2002). No nível de mRNA, Zhong et al. (2007) também observaram aumento de expressão nos carcinomas orais e os dados permitiram a detecção de uma correlação significativa com o grau de diferenciação, sendo os tumores menos diferenciados aqueles com maiores níveis de transcritos.

Vários fatores extracelulares induzem a expressão dos genes das queratinas quando ligados aos seus receptores nas membranas de queratinócitos. Por exemplo, o fator de necrose tumoral 1 ativa o gene da K6 (revisto por Bragulla e Homberger, 2009). Efeito 
similar sobre os genes de K6, K16 ou K17 é observado para interleucina-1, fator de crescimento epidérmico e fator de crescimento transformante. Sob a ação do ácido retinóico, os níveis de K6 e K17 diminuem e os de K19 aumentam.

Os mecanismos que regulam a expressão de KRT19 em câncer parecem ser dependentes do contexto celular e tecido-específicos (Bambang et al., 2009). Por exemplo, em câncer de mama, sua expressão é regulada por estrógenos (Choi et al., 2000) e já foi associada com a sinalização do HER-2/neu (Zhang et al. 2005). Em câncer pancreático, essa regulação é realizada pelo fator Kruppel-like GKLF/KLF4 e pelo Sp1 (Brembeck e Rustgi, 2000).

\section{Mesotelina}

A mesotelina é um antígeno de diferenciação cuja expressão em tecidos normais está restrita a células mesoteliais que limitam a pleura, o pericárdio e o peritônio. O gene da mesotelina (MSLN) está localizado em 16 p13.3 e codifica uma proteína precursora de 71 $\mathrm{kDa}$, cuja porção amino origina a citocina secretada conhecida como fator de potencialização de megacariócito - MPF (Kojima et al., 1995) e um fragmento de 40kD, a mesotelina, que é ligado à membrana por glicosil-fosfatidilinositol (revisto por Hassan e Ho, 2008) (Figura 3).

O aumento de expressão do gene $M S L N$ já foi observado em vários tumores, como câncer pancreático, de ovário e mesotelioma (Chang e Pastan, 1996), bem como em câncer de cabeça e pescoço, vulva, endométrio, pulmão, fígado e esôfago (Chang et al., 1992; Ordonez, 2003; Miettinen e Sarlomo-Rikala, 2003).

Em uma análise de sequências genômicas ao redor do gene MSLN, Hucl et al. (2007) descobriram um elemento estimulador modular (enhancer), responsável pelo aumento de níveis câncer-específicos da mesotelina. A atividade desse elemento foi dependente da ligação de um de seus sítios ativos, o MCAT, ao fator de transcrição TEF-1.

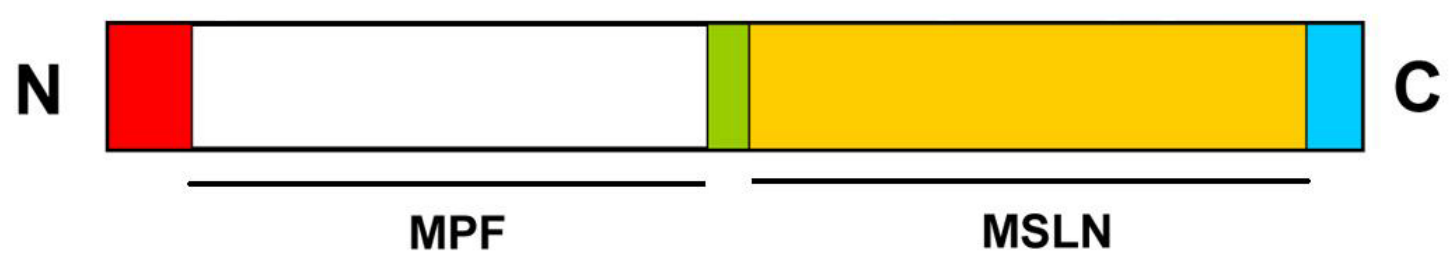

Figura 3. Esquema do produto do gene MSLN mostrando o precursor de 622 aminoácidos e as regiões que originam os dois produtos MPF e MSLN (modificado de Hassan e Ho, 2008). 
A elevada expressão da mesotelina em algumas neoplasias humanas e sua limitada expressão nos tecidos normais somadas à existência de formas relacionadas solúveis, como o MPF, permitem métodos de diagnóstico e imunoterapia. Além disso, a presença de anticorpos específicos para a proteína em uma parcela significativa de pacientes abre a possibilidade de desenvolvimento de vacinas. Vários protocolos relacionados com essas terapias estão em andamento (Ho et al., 2005; Hassan e Ho, 2008; Uehara et al., 2008).

O entendimento da função biológica da mesotelina é ainda incompleto, especialmente porque camundongos knockout para o gene não exibem anomalias anatômicas ou histológicas em qualquer dos tecidos nos quais está normalmente expressa (Bera e Pastan, 2000). Recentemente, Uehara et al. (2008), avaliando linhagens celulares de câncer de mama, mostraram que o aumento de expressão de MSLN está implicado na promoção de crescimento independente de ancoragem. Esse achado é concordante com os dados sobre a ligação da mesotelina com a mucina 16 (ou CA125) e uma provável estimulação e disseminação de células neoplásicas (Gubbels et al., 2006). Outros estudos in vitro também revelaram que a mesotelina é induzida pela via de sinalização do Wnt, responsável pela regulação de uma variedade de processos biológicos, incluindo proliferação, diferenciação e apoptose (Prieve e Moon, 2003).

Em relação à proliferação celular, Bharadwaj et al. (2008) verificaram que níveis elevados da mesotelina promovem a ativação do fator de transcrição Stat3, o que leva ao aumento de expressão da ciclina $\mathrm{E}$ e de complexos ciclina E/quinase CDK2 e à indução da transição G1-S.

\section{Calicreína 8}

As calicreínas são serino-proteases codificadas, na espécie humana, por 15 genes localizados em tandem, especificamente em 19q13.4, com 5 exons codificadores similares (Yousef e Diamandis, 2001). Seu transcritoma é amplo, com mais de 50 isoformas geradas por splicing alternativo. Todos os genes das calicreínas humanas são traduzidos em préproenzimas, que são clivadas para proenzimas. Após secreção, são processadas por proteases ou mesmo por calicreínas e tornam-se enzimas extracelulares ativas (Yousef e Diamandis, 2001; Borgoño et al., 2004) (Figura 4). O membro mais conhecido dessa família é a calicreína 3 - também conhecida como antígeno próstata-específico ou PSA - que é um marcador do câncer de próstata. 


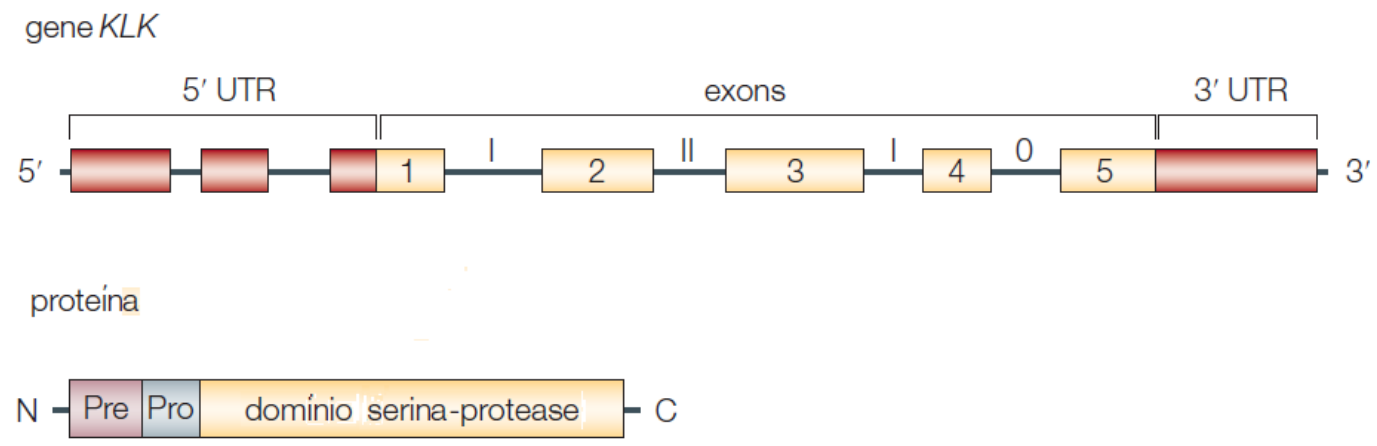

Figura 4. Esquema do gene e da proteína das calicreínas segundo Borgoño e Diamandis (2004).

O gene da calicreína 8 (KLK8), também conhecido como neuropsina ou ovasina, foi clonado por Yoshida et al. (1998) utilizando inicialmente análise de dados de ESTs, seguida por avaliação de expressão em hipocampo e queratinócitos. Mitsui et al. (1999) observaram que a calicerína 8 ocorre em duas isoformas (tipo 1 e 2) idênticas exceto pelo fato de que a segunda possui uma inserção de 135 bp no segundo éxon codificante. Essa última é preferencialmente expressa no cérebro humano adulto e no hipocampo, mas ambas estão presentes no cérebro fetal. Na doença de Alzheimer, os níveis de mRNA da KLK8 no hipocampo mostram elevação de 11,5 vezes (Shimizu-Okabe et al., 2001).

Diferentes tecidos e fluidos biológicos de indivíduos saudáveis também mostram a presença de KLK8, como esôfago, pele, testículo, tonsila, rim, mama, glândula salivar, leite, líquido amniótico, plasma seminal e soro (Gan et al., 2000; Kishi T et al., 2003).

$\mathrm{Na}$ pele, a KLK8 está localizada na camada espinhosa superior do estrato córneo. Uma expressão elevada de seu transcrito e proteína foi observada em doenças de pele, como psoríase, liquen planus e dermatite atópica, o que sugere seu envolvimento na etiologia de doenças de pele inflamatórias (Kuwae et al., 2002; Komatsu et al., 2005). Os camundongos knockout para o gene $K L K 8$, embora sem diferença histológica de pele em relação ao selvagem, mostram recuperação lenta da epiderme após inflamação induzida por raios UVB (Kirihara et al., 2003). Em um modelo animal de psoríase, que causa proliferação da epiderme e hiperqueratose, ocorre um aumento de KLK8 tanto em animais knockout como selvagens, mas esses últimos exibem maior proliferação e descamação de células do epitélio que os primeiros (Kishibe et al., 2007). Portanto, a ausência de KLK8 pode contribuir para um fenótipo hiperqueratótico.

A caracterização bioquímica da calicreína 8 mostrou que ela é uma protease com especificidade semelhante à tripsina. Rajapakse e colaboradores (2005) verificaram a 
capacidade da KLK8 em degradar fibronectina e colágeno tipo IV, componentes da matriz extracelular e da membrana basal, respectivamente. Geralmente a degradação de ambas as proteínas são descritas como uma etapa crítica para as células cancerosas invadirem outros tecidos e formarem metástases. Esses dados sugerem que a KLK8 pode estar envolvida no fenótipo invasivo da célula neoplásica.

Os mesmos autores também observaram que a calicreína 8 foi capaz de convertar o ativador de plaminogênio tecidual de cadeia única (tPA) para sua forma protéica de cadeia dupla (Rajapakse et al., 2005). O tPA de cadeia única tem atividade limitada para produção de plasmina, exceto se o cofator fibrina estiver presente, enquanto o tPA de cadeia dupla exibe atividade mesmo na ausência de fibrina (Stubbs et al., 1998). Portanto, a KLK8 pode iniciar, na ausência de fibrina, o sistema tPA/plasmina, que catalisa a degradação de proteínas da membrana basal e da matriz extracelular, facilitando a invasão de tecidos adjacentes pelas células neoplásicas (Andreasen et al., 2000). Nesse mesmo contexto, Ohler et al. (2010) demonstraram que a KLK8 é capaz de ativar metaloproteases, como a meprina- $\beta$, aparentemente envolvida na diferenci̧ãão terminal de queratinócitos ( BeckerPauly et al., 2007). Provavelmente como um mecanismo de controle, a calicreína 8 é inibida em queratinócitos pela proteína serpina $\mathrm{B} 6$, um importante regulador da proteólise (Scott et al., 2007).

Em processos neoplásicos, já foram observados níveis reduzidos da KLK8 em carcinoma de mama (Yousef et al., 2004) e níveis elevados em líquido ascítico, soro e células de carcinoma de ovário (Gan et al., 2000; Kishi et al., 2003; Underwood et al., 1999), e em tecido tumoral de pacientes com câncer de cólon (Yousef et al., 2004) e cervical (Cané et al., 2004). Em carcinomas de cabeça e pescoço, os dados são ainda controversos, com diminuição de expressão da calicreína 8 em metástases linfonodais, referida por Liu et al. (2008), e aumento de sua expressão bem como de outras KLKs em tecidos tumorais (Pettus et al., 2009).

Os genes de várias calicreínas, entre elas a 8, apresentam elementos de resposta a glicocorticóides e a STAT-5. A presença desses elementos pode explicar a modulação da expressão dessas KLKs pela dexametasona em células de carcinoma cervical e de mama (Shaw e Diamandis, 2008). Considerando o papel antiinflamatório dos glicocorticóides, tanto em câncer como em doenças de pele, os mecanismos envolvidos nessa regulação merecem investigação detalhada. 


\section{OBJETIVOS}

Considerando os dados da literatura e aqueles obtidos previamente por nosso grupo, o presente projeto investigou o envolvimento de queratinas, mesotelina e calicreína na tumorigênese de cabeça e pescoço. Os objetivos específicos do presente projeto compreenderam:

a) Estabelecer a cultura primária de queratinócitos bucais humanos normais para avaliação de expressão de genes de interesse e posterior comparação com células neoplásicas de mucosa oral.

b) Com a utilização do método de RT-PCR quantitativa, analisar o padrão de expressão dos genes KRT6A, KRT19, MSLN e KLK8 em linhagens celulares procedentes de tumores epidermóides de cabeça e pescoço comparando-o com o de células normais correspondentes.

c) Com a utilização do método de RT-PCR quantitativa, analisar o padrão de expressão dos genes KRT6A, KRT19, MSLN e KLK8 em tumores primários desse sítio anatômico com características agressivas ou menos agressivas e compará-lo com tecidos normais correspondentes.

d) Investigar o potencial dos genes de interesse como marcadores do fenótipo metastático. 


\section{MATERIAL E MÉTODOS}

\section{Casuística}

No presente trabalho, foi analisado um total de 63 casos de carcinomas epidermóides primários de cabeça e pescoço, que incluíram 29 pares de tumor-margem procedentes de carcinoma de laringe (15 No e $14 \mathrm{~N}+$ ), 10 pares de carcinoma de língua (4 N0 e $6 \mathrm{~N}+$ ) e 24 de soalho de boca (14 No e $10 \mathrm{~N}+$ ). Na Tabela 1 estão apresentados os dados de cada caso sobre idade, sexo, exposição a fumo e álcool, sítio primário do carcinoma e características anatomopatológicas.

De cada paciente, foram obtidas amostras do tumor e de sua respectiva margem após ressecção cirúrgica no Instituto Arnaldo Vieira de Carvalho, SP, no Hospital Heliópolis, SP, no Hospital das Clínicas, SP e em hospitais de São José dos Campos, SP. O material foi colhido pela equipe do Projeto Genoma de Cabeça e Pescoço (GENCAPO), um consórcio colaborativo com mais de 50 pesquisadores de nove instituições do Estado de São Paulo, cujo objetivo foi desenvolver análises clínicas, genéticas e epidemiológicas de carcinomas epidermóides de cabeça e pescoço. Esse material faz parte do banco de amostras do projeto temático FAPESP 04/12054-9 "Busca de marcadores de agressividade em tumores de cabeça e pescoço", aprovado pela Comissão Nacional de Ética em Pesquisa (CONEP: parecer n⿳01763/05 - processo 25000). Como novos objetivos foram acrescentados, 0 presente estudo foi avaliado e recebeu aprovação como aditivo do projeto acima citado.

Imediatamente após a cirurgia, as amostras foram armazenadas em nitrogênio líquido e posteriormente submetidas à macrodissecção por um médico patologista que confirmou, em seções coradas por hematoxilina-eosina de todos os casos, a presença de pelo menos $70 \%$ de células tumorais nos carcinomas e ausência dessas células nas margens cirúrgicas.

O conjunto de amostras foi derivado de três sub-sítios anatômicos (língua, soalho de boca e laringe (C02, C04 e C32, respectivamente, segundo o Código Internacional de Doenças / CID-10). Os casos foram classificados em dois sub-grupos principais: aqueles com presença $(\mathrm{N}+)$ ou ausência (N0) de metástases em linfonodos regionais, utilizando os dados do sistema TNM (Tumor-Node-Metastasis) da Union Internationale Contre le Câncer - UICC (http://www.uicc.org/). 
Tabela 1. Lista de amostras de CECP e suas respectivas características.

\begin{tabular}{|c|c|c|c|c|c|c|c|c|c|c|c|c|c|}
\hline Caso & Sexo & Idade & Fuma & Etilista & Sítio & TNM & Estádio & $\begin{array}{l}\text { Diferenciação } \\
\text { Histológica }\end{array}$ & $\begin{array}{l}\text { Infiltração } \\
\text { Vascular } \\
\text { Sanguínea }\end{array}$ & $\begin{array}{c}\text { Infiltração } \\
\text { Linfática }\end{array}$ & $\begin{array}{l}\text { Invasão } \\
\text { Perineural }\end{array}$ & $\begin{array}{l}\text { Infiltrado } \\
\text { Inflamatorio } \\
\text { peri-tumoral }\end{array}$ & Óbito \\
\hline CP1/0021 & M & 43 & Sim & Sim & Língua & T3 NO MO & III & Moderadamente & Presente & Presente & Ausente & Moderado & Nao \\
\hline CP1/0024 & $\mathrm{F}$ & 48 & Sim & Nunca & $\begin{array}{l}\text { Soalho de } \\
\text { Boca }\end{array}$ & T1 NO MO & 1 & Moderadamente & Ausente & Ausente & Ausente & Moderado & Nao \\
\hline CP1/0032 & $\mathrm{M}$ & 64 & Sim & Sim & $\begin{array}{l}\text { Soalho de } \\
\text { Boca }\end{array}$ & T4 N2C M0 & IV & $\begin{array}{c}\text { Pouco } \\
\text { diferenciado }\end{array}$ & Ausente & Presente & Presente & Moderado & $\begin{array}{c}\text { Pela } \\
\text { Neoplasia }\end{array}$ \\
\hline CP1/0055 & M & 56 & Sim & Sim & $\begin{array}{l}\text { Soalho de } \\
\text { Boca }\end{array}$ & T4 N2B M0 & IV & Bem diferenciado & Ausente & Ausente & Ausente & Moderado & $\begin{array}{c}\text { Pela } \\
\text { Neoplasia }\end{array}$ \\
\hline CP1/0056 & $\mathrm{F}$ & 54 & $\begin{array}{c}\text { No } \\
\text { passado }\end{array}$ & No passado & Laringe & T3 NO MO & III & Moderadamente & Ausente & Ausente & Presente & Moderado & Nao \\
\hline CP1/0057 & M & 57 & Sim & No passado & Língua & T4 N2B M0 & IV & Moderadamente & Ausente & Ausente & Presente & Escasso & $\begin{array}{l}\text { Outras } \\
\text { Causas }\end{array}$ \\
\hline CP1/0075 & M & 54 & Sim & Sim & $\begin{array}{l}\text { Soalho de } \\
\text { Boca }\end{array}$ & T3 NO MO & III & Moderadamente & Ausente & Ausente & Ausente & Escasso & Nao \\
\hline CP1/0080 & $M$ & 67 & Sim & Sim & $\begin{array}{l}\text { Soalho de } \\
\text { Boca }\end{array}$ & T3 NO MO & III & Bem diferenciado & Ausente & Ausente & Ausente & Escasso & Nao \\
\hline CP1/0083 & M & 72 & $\begin{array}{c}\text { No } \\
\text { passado }\end{array}$ & No passado & $\begin{array}{l}\text { Soalho de } \\
\text { Boca }\end{array}$ & T2 NO MO & II & Bem diferenciado & Ausente & Ausente & Ausente & Escasso & Nao \\
\hline CP1/0089 & M & 72 & $\begin{array}{c}\text { No } \\
\text { passado }\end{array}$ & No passado & $\begin{array}{c}\text { Soalho de } \\
\text { Boca }\end{array}$ & T2 NO MO & II & Moderadamente & Ausente & Ausente & Presente & Moderado & Nao \\
\hline CP1/0151 & M & 47 & Sim & Sim & Língua & T3 NO MO & III & Moderadamente & Ausente & Ausente & Presente & Moderado & $\begin{array}{c}\text { Pela } \\
\text { Neoplasia }\end{array}$ \\
\hline CP1/0191 & M & 63 & Sim & Sim & $\begin{array}{l}\text { Soalho de } \\
\text { Boca }\end{array}$ & T3 NO MO & III & Moderadamente & Ausente & Ausente & Presente & Escasso & Nao \\
\hline CP1/0200 & $\mathrm{M}$ & 55 & Sim & Sim & Língua & T3 NO MO & III & Moderadamente & Ausente & Presente & Presente & Escasso & Nao \\
\hline CP1/0213 & $M$ & 68 & Sim & Sim & $\begin{array}{l}\text { Soalho de } \\
\text { Boca }\end{array}$ & T4 N1 M0 & IV & Bem diferenciado & Ausente & Presente & Ausente & Escasso & Nao \\
\hline CP1/0228 & M & 40 & Sim & Sim & $\begin{array}{l}\text { Soalho de } \\
\text { Boca }\end{array}$ & T4 N2C M0 & IV & Moderadamente & Ausente & Presente & Presente & Escasso & Nao \\
\hline CP1/0233 & $\mathrm{F}$ & 39 & Nunca & Nunca & $\begin{array}{c}\text { Soalho de } \\
\text { Boca }\end{array}$ & T4 N2C M0 & & $\begin{array}{c}\text { Pouco } \\
\text { diferenciado }\end{array}$ & Ausente & Presente & Presente & Escasso & $\begin{array}{c}\text { Pela } \\
\text { Neoplasia }\end{array}$ \\
\hline CP1/0240 & M & 75 & Sim & Sim & $\begin{array}{l}\text { Soalho de } \\
\text { Boca }\end{array}$ & T2 NO MO & II & Moderadamente & Ausente & Ausente & Ausente & Escasso & $\mathrm{NaO}$ \\
\hline CP1/0255 & M & 50 & $\begin{array}{c}\text { No } \\
\text { passado }\end{array}$ & Sim & $\begin{array}{l}\text { Soalho de } \\
\text { Boca }\end{array}$ & T2 NO MO & II & Moderadamente & Ausente & Ausente & Presente & Escasso & Nao \\
\hline CP1/0258 & $\mathrm{M}$ & 46 & Sim & Sim & $\begin{array}{l}\text { Soalho de } \\
\text { Boca }\end{array}$ & T1 N2B M0 & IV & Bem diferenciado & Ausente & Presente & Ausente & Escasso & Nao \\
\hline CP1/0262 & $\mathrm{M}$ & 62 & $\begin{array}{c}\text { No } \\
\text { passado }\end{array}$ & Sim & Língua & T3 NO MO & III & Moderadamente & Ausente & Ausente & Presente & Escasso & Nao \\
\hline CP1/0348 & $\mathrm{M}$ & 51 & Sim & Sim & Laringe & T4 NO MO & IV & Bem Diferenciado & Ausente & Ausente & Presente & Escasso & Nao \\
\hline CP1/0357 & $\mathrm{M}$ & 76 & Nunca & Nunca & Laringe & T4 NO MO & IV & Bem Diferenciado & Ausente & Ausente & Presente & Escasso & Nao \\
\hline CP1/0359 & $\mathrm{M}$ & 55 & Sim & Sim & Laringe & T4 NO MO & IV & Moderadamente & Ausente & Ausente & Presente & Escasso & Nao \\
\hline CP1/0363 & $M$ & 64 & Sim & Sim & $\begin{array}{c}\text { Soalho de } \\
\text { Boca }\end{array}$ & T2 N2C M0 & IV & Moderadamente & Ausente & Presente & Presente & Escasso & Nao \\
\hline
\end{tabular}




\begin{tabular}{|c|c|c|c|c|c|c|c|c|c|c|c|c|c|}
\hline CP1/0366 & M & 49 & $\begin{array}{c}\text { No } \\
\text { passado }\end{array}$ & Sim & $\begin{array}{l}\text { Soalho de } \\
\text { Boca }\end{array}$ & T4 N0 MO & IV & Bem Diferenciado & Ausente & Ausente & Presente & & Nao \\
\hline CP1/0370 & M & 55 & Sim & Sim & $\begin{array}{l}\text { Soalho de } \\
\text { Boca }\end{array}$ & T4 NO MO & IV & Bem Diferenciado & Ausente & Ausente & Presente & Escasso & Nao \\
\hline CP1/0384 & M & 46 & $\begin{array}{c}\text { No } \\
\text { passado }\end{array}$ & Sim & $\begin{array}{l}\text { Soalho de } \\
\text { Boca }\end{array}$ & T3 NO MO & III & Moderadamente & Ausente & Ausente & Presente & Moderado & Nao \\
\hline CP1/0385 & M & 39 & Nunca & Nunca & Laringe & T4 NO MO & IV & Bem Diferenciado & Ausente & Ausente & Presente & Escasso & Nao \\
\hline CP2/0051 & M & 46 & Sim & Sim & $\begin{array}{l}\text { Soalho de } \\
\text { Boca }\end{array}$ & T2 N2B M0 & IV & Bem diferenciado & Ausente & Ausente & Ausente & Moderado & $\begin{array}{c}\text { Pela } \\
\text { Neoplasia }\end{array}$ \\
\hline CP2/0096 & M & 46 & Sim & Sim & Laringe & T2 N1 M0 & III & Bem diferenciado & Ausente & Ausente & Ausente & Moderado & Nao \\
\hline CP2/0122 & M & 56 & Sim & Sim & $\begin{array}{l}\text { Soalho de } \\
\text { Boca }\end{array}$ & T2 N2B M0 & IV & Moderadamente & Ausente & Ausente & Ausente & Moderado & $\begin{array}{c}\text { Pela } \\
\text { Neoplasia }\end{array}$ \\
\hline CP2/0168 & $\mathrm{F}$ & 70 & $\begin{array}{c}\text { No } \\
\text { passado }\end{array}$ & Nunca & $\begin{array}{l}\text { Soalho de } \\
\text { Boca }\end{array}$ & T2 NO MO & II & Moderadamente & Ausente & Ausente & Ausente & Moderado & $\begin{array}{l}\text { Outras } \\
\text { Causas }\end{array}$ \\
\hline CP2/1002 & M & 59 & Sim & Sim & Língua & T2 N2C M0 & IV & Bem diferenciado & Ausente & Ausente & Ausente & Intenso & $\begin{array}{c}\text { Pela } \\
\text { Neoplasia }\end{array}$ \\
\hline CP3/0018 & M & 61 & Sim & No passado & Laringe & T4 N2B M0 & IV & Moderadamente & Ausente & Ausente & Ausente & Moderado & $\begin{array}{c}\text { Pela } \\
\text { Neoplasia }\end{array}$ \\
\hline CР3/0019 & M & 54 & Sim & Sim & Laringe & T4 NO MO & IV & Moderadamente & Ausente & Ausente & Ausente & Escasso & Nao \\
\hline CP3/0031 & M & 54 & Sim & Sim & Laringe & T4 N2C MO & IV & Moderadamente & Ausente & Ausente & Presente & Moderado & $\begin{array}{c}\text { Pela } \\
\text { Neoplasia }\end{array}$ \\
\hline CP3/0033 & M & 51 & Sim & No passado & $\begin{array}{l}\text { Soalho de } \\
\text { Boca }\end{array}$ & T3 NO MO & III & Moderadamente & Ausente & Ausente & Presente & Moderado & Nao \\
\hline CP3/0035 & M & 54 & Sim & Sim & Laringe & T4 NO MO & IV & Moderadamente & Ausente & Ausente & Ausente & Moderado & Nao \\
\hline CP3/0049 & M & 62 & $\begin{array}{c}\text { No } \\
\text { passado }\end{array}$ & No passado & Língua & T2 N2B M0 & IV & Moderadamente & Ausente & Ausente & Presente & Moderado & Nao \\
\hline CP3/0050 & $\mathrm{F}$ & 44 & Sim & No passado & Língua & T2 N1 M0 & III & Bem diferenciado & Ausente & Ausente & Presente & Moderado & $\begin{array}{c}\text { Pela } \\
\text { Neoplasia }\end{array}$ \\
\hline CP3/0076 & M & 64 & $\begin{array}{c}\text { No } \\
\text { passado }\end{array}$ & No passado & Laringe & T4 N2B M0 & IV & $\begin{array}{c}\text { Pouco } \\
\text { diferenciado }\end{array}$ & Ausente & Ausente & Presente & Escasso & Nao \\
\hline CP3/0085 & M & 59 & Sim & Sim & Laringe & T4 N3 M0 & IV & $\begin{array}{c}\text { Pouco } \\
\text { diferenciado }\end{array}$ & Ausente & Ausente & Ausente & Moderado & Nao \\
\hline CP3/0087 & M & 52 & Sim & Sim & Língua & T2 N2C M0 & IV & Moderadamente & Ausente & Ausente & Presente & Moderado & Nao \\
\hline CP3/0096 & M & 54 & Sim & Nunca & Laringe & T4 NO MO & IV & & Ausente & Ausente & Ausente & Escasso & Nao \\
\hline CP3/0102 & M & 49 & Sim & Sim & Laringe & T2 N1 M0 & III & Bem diferenciado & Presente & Ausente & Ausente & Escasso & $\mathrm{NaO}$ \\
\hline CP3/0105 & M & 67 & $\begin{array}{c}\text { No } \\
\text { passado }\end{array}$ & Sim & Laringe & T4 N2C M0 & IV & Moderadamente & Ausente & Ausente & Presente & Moderado & $\begin{array}{c}\text { Pela } \\
\text { Neoplasia }\end{array}$ \\
\hline CP3/0118 & M & 45 & Sim & Sim & Língua & T4 N3 M0 & IV & Moderadamente & Ausente & Ausente & Ausente & Escasso & Nao \\
\hline СР3/0119 & M & 67 & Sim & Sim & Laringe & T4 N2C M0 & IV & Bem diferenciado & Ausente & Presente & Presente & & $\begin{array}{c}\text { Pela } \\
\text { Neoplasia }\end{array}$ \\
\hline CP3/0120 & $\mathrm{F}$ & 46 & Sim & Sim & $\begin{array}{l}\text { Soalho de } \\
\text { Boca }\end{array}$ & T2 NO MO & II & Bem diferenciado & Ausente & Ausente & Ausente & Moderado & $\begin{array}{c}\text { Pela } \\
\text { Neoplasia }\end{array}$ \\
\hline CP3/0125 & M & 63 & $\begin{array}{c}\text { No } \\
\text { passado }\end{array}$ & No passado & Laringe & T4 N3 M0 & IV & $\begin{array}{c}\text { Pouco } \\
\text { diferenciado }\end{array}$ & Presente & Presente & Presente & Moderado & Nao \\
\hline CP3/0136 & M & 65 & Sim & Sim & Laringe & T4 N2B M0 & IV & Bem diferenciado & Ausente & Ausente & Ausente & Escasso & $\begin{array}{c}\text { Pela } \\
\text { Neoplasia }\end{array}$ \\
\hline CP3/0153 & M & 49 & Sim & No passado & Laringe & T3 N3 MO & IV & Moderadamente & Presente & Presente & Presente & Moderado & $\begin{array}{c}\text { Pela } \\
\text { Neoplasia }\end{array}$ \\
\hline
\end{tabular}




\begin{tabular}{|c|c|c|c|c|c|c|c|c|c|c|c|c|c|}
\hline CP3/0199 & M & 74 & Sim & Nunca & Laringe & T4 NO MO & IV & Bem diferenciado & Ausente & Ausente & Ausente & Moderado & Nao \\
\hline CP3/0249 & M & 61 & Sim & Sim & Laringe & T2 NO M-X & & Moderadamente & Ausente & Ausente & Ausente & & Nao \\
\hline CP3/0280 & M & 52 & Sim & Sim & $\begin{array}{l}\text { Soalho de } \\
\text { Boca }\end{array}$ & T1 N2B M-X & & Moderadamente & Ausente & Ausente & Presente & & Nao \\
\hline CP3/0377 & M & 78 & $\begin{array}{c}\text { No } \\
\text { passado }\end{array}$ & No passado & Laringe & T4 N0 M-X & & Moderadamente & Ausente & Ausente & Presente & & $\begin{array}{l}\text { Outras } \\
\text { Causas }\end{array}$ \\
\hline CP3/0390 & M & 55 & Sim & Sim & Laringe & T4 N0 M-X & & Moderadamente & Ausente & Ausente & Ausente & Intenso & Nao \\
\hline CP3/0411 & M & 49 & Sim & Sim & Laringe & T4 N2B M-X & & Moderadamente & Presente & Ausente & Presente & Intenso & $\begin{array}{l}\text { Outras } \\
\text { Causas }\end{array}$ \\
\hline CP3/0433 & M & 56 & Sim & Sim & Laringe & T4 NO M-X & & Bem Diferenciado & Ausente & & Ausente & Escasso & Nao \\
\hline CP3/0464 & M & 79 & Sim & No passado & Laringe & T4 N2B M-X & & Moderadamente & Ausente & Ausente & Ausente & Intenso & $\begin{array}{c}\text { Pela } \\
\text { Neoplasia }\end{array}$ \\
\hline CP4/0001 & M & 52 & $\begin{array}{c}\text { No } \\
\text { passado }\end{array}$ & No passado & Laringe & T3 N2C M-X & & Moderadamente & Ausente & Presente & Ausente & Moderado & Nao \\
\hline CP4/0016 & $\mathrm{F}$ & 52 & Sim & Sim & Laringe & T1 N0 M-X & & Bem diferenciado & Ausente & Ausente & Ausente & Escasso & Nao \\
\hline CP4/0024 & M & 45 & Sim & No passado & Laringe & T4 NO M-X & & Bem diferenciado & Ausente & Ausente & Ausente & Intenso & \\
\hline
\end{tabular}


No presente estudo, foram também estudadas as linhagens celulares Hep-2 (uma linhagem originalmente descrita como sendo de laringe), FaDu (procedente de carcinoma de orofaringe), UM-SCC-38 (carcinoma de tonsila pilar) e SCC9 (carcinoma de língua). As duas primeiras linhagens foram gentilmente cedidas pela Profa. Dra. Otávia Luisa Silva Damas de Caballero, Instituto Ludwig, NY. A linhagem UM-SCC-38 foi cedida pelo Prof. Dr. Thomas Carey da Universidade de Michigan e a linhagem SCC9 foi cedida pelo Prof. Dr. Márcio Mateus Beloti, da Faculdade de Odontologia de Ribeirão Preto, Universidade de São Paulo (Tabela 2).

Como controle, foram estudados queratinócitos bucais humanos normais, cedidos pela Profa. Dra. Mônica Beatriz Mathor, do Instituto de Pesquisas Energéticas e Nucleares, Universidade de São Paulo, ou procedentes de cultura primária desenvolvida em nosso laboratório a partir de amostras de gengiva, obtidas em cirurgias estéticas ou para retirada de terceiro molar e realizadas pelo Dr. Breno Gutierrez Motta. Além dos queratinócitos, foram utilizados fibroblastos murinos (ATCC No catálogo CCL-92 3T3-Swiss albino), gentilmente cedidos pela Profa. Dra. Mônica Beatriz Mathor,

Tabela 2. Características das linhagens utilizadas no estudo segundo a American Type Culture Collection (ATCC).

\begin{tabular}{|l|l|c|c|}
\hline \multirow{2}{*}{ Linhagem } & Características & \multicolumn{2}{|c|}{ Dados dos pacientes } \\
\cline { 3 - 4 } Hep-2 & $\begin{array}{l}\text { Linhagem celular epidermóide } \\
\text { originalmente descrita como sendo de } \\
\text { carcinoma de laringe, com } \\
\text { contaminação pela linhagem HeLa } \\
\text { (ATCC: CCL23) }\end{array}$ & Não consta & Não consta \\
\hline FaDu & $\begin{array}{l}\text { Carcinoma epidermóide de células } \\
\text { escamosas de faringe (ATCC: HTB-43) }\end{array}$ & 56 & Masculino \\
\hline SCC-9 & $\begin{array}{l}\text { Carcinoma epidermóide de células } \\
\text { escamosas de língua (ATCC: CRL- } \\
1629)\end{array}$ & 25 & Masculino \\
\hline UM-SCC-38 & $\begin{array}{l}\text { Carcinoma epidermóide de tonsila } \\
\text { T2N2aM0, estágio IV, moderadamente } \\
\text { diferenciado, sem terapia prévia }\end{array}$ & 60 & Masculino \\
\hline
\end{tabular}

\section{Metodologia}

\section{Cultura de Linhagens Celulares}

O meio de cultura Dulbecco's Modified Eagle's Medium (DMEM) (Gibco, Carlsbad, CA, USA) foi utilizado para crescimento e manutenção da linhagem celular UM-SCC-38 e o meio MEM (Cultilab, Campinas, SP, Brasil) foi utilizado para as linhagens Hep-2 e FaDu. Ambos 
foram suplementados com $10 \%$ de soro fetal bovino (Gibco), aminoácidos não essenciais 10mM (Gibco), penicilina 100U/mL (Gibco), estreptomicina 100 $\mathrm{g} / \mathrm{mL}$ (Gibco) e anfotericina B 2,5 $\mathrm{g} / \mathrm{mL}$ (Gibco). Foi também adicionado piruvato de sódio $1 \mathrm{mM}$ (Sigma-Aldrich, St. Louis, MO, USA) aos meios das linhagens Hep-2 e FaDu, e L-glutamina 2mM (Gibco) ao meio da UM-SCC-38. A linhagem SCC9 foi cultivada em meio DMEM suplementado com nutriente F-12 (Gibco) na proporção de 1:1, além de $10 \%$ de soro fetal bovino, hidrocortisona $0,4 \mu \mathrm{g} / \mathrm{mL}$ (Sigma-Aldrich), penicilina $100 \mathrm{U} / \mathrm{mL}$ (Gibco), estreptomicina $100 \mu \mathrm{g} / \mathrm{mL}$ (Gibco) e anfotericina B 2,5 $\mathrm{g} / \mathrm{mL}$ (Gibco). As linhagens foram mantidas a $37^{\circ} \mathrm{C}$ em atmosfera de $5 \%$ de $\mathrm{CO}_{2}$, em frascos plásticos de 25 ou $75 \mathrm{~cm}^{2}$.

Durante a fase de manutenção das linhagens, os meios de cultura foram substituídos a cada três ou quatro dias e, quando uma subconfluência de aproximadamente $70 \%$ foi atingida, as células foram tripsinizadas e subdivididas em duas réplicas. Para isto, o meio de cultura foi removido, as células lavadas com $10 \mathrm{~mL}$ de solução salina tamponada com fosfato $\mathrm{pH} 7,4$ (PBS) e incubadas a $37^{\circ} \mathrm{C}$ com $1 \mathrm{~mL}$ ou $2 \mathrm{~mL}$ de solução de tripsina 0,05\%/EDTA 0,02\% (Gibco), para frascos de $25 \mathrm{~cm}^{2}$ ou $75 \mathrm{~cm}^{2}$, respectivamente. Dependendo da linhagem, as células destacaram-se do soalho do frasco de cultura após um período de 2 e 5 min, o que foi constatado por observação em microscópio inverido. A ação da tripsina foi interrompida pela adição de meio de cultura DMEM com 10\% de soro fetal bovino.

Para manutenção do estoque de linhagens, as células foram tripsinizadas (conforme descrito acima), centrifugadas a $1500 \mathrm{rpm}$ durante 5 min e ressuspendidas em solução de dimetilsulfóxido 10\% (DMSO, Sigma-Aldrich) e 90\% de soro fetal bovino, sendo em seguida congeladas em nitrogênio líquido.

Para os experimentos do presente estudo, as células foram semeadas com uma densidade de $1 \times 10^{6}$ células $/ \mathrm{mL} /$ frasco de $75 \mathrm{~cm}^{2}$ e mantidas em meio completo com $10 \%$ de soro por 24 horas para que ocorresse sua adesão ao frasco. Após esse período, o meio de cultura foi trocado por outro sem soro, para que as células entrassem em estado de quiescência e parassem de proliferar. Após mais 24 horas, o meio foi substituído pelo meio completo com $10 \%$ de soro. A partir desse ponto, foram contadas 24,48 e 72 horas para coleta das células.

\section{Cultura Primária de Queratinócitos}

Fragmentos de gengiva de pacientes submetidos a cirurgias estéticas ou para retirada de terceiro molar foram mantidos por até 12 horas antes de seu processamento em meio de transporte DMEM, sem soro, com penicilina (200 U/mL), streptomicina $(200 \mu \mathrm{g} / \mathrm{mL})$, gentamicina $(80 \mu \mathrm{g} / \mathrm{mL})$ e anfotericina $B(5 \mu \mathrm{g} / \mathrm{mL})$. Em cabine de fluxo laminar, os fragmentos forma lavados em solução balanceada de Hanks (HBSS), por alguns segundos, 
para retirada de resíduos de sangue. Após essa etapa, o material foi mergulhado em álcool etílico $70 \%$ por 15 s, e novamente tratados com HBSS. O procedimento foi repetido por mais duas vezes, sendo que a última solução foi suplementada com penicilina $(100 \mathrm{U} / \mathrm{mL})$, streptomicina $(100 \mu \mathrm{g} / \mathrm{mL})$, gentamicina $(40 \mu \mathrm{g} / \mathrm{mL})$ e anfotericina $B(2.5 \mu \mathrm{g} / \mathrm{mL})$.

Em seguida, foi feita a separação do epitélio com pinça e lâmina de bisturi, sobre uma placa de Petri. O epitélio foi, então, subdividido em fragmentos menores, que foram imersos em solução de tripsina 0,05\%/EDTA $0,02 \%$ e mantidos sobre agitação branda a $37^{\circ} \mathrm{C}$. A cada 30 min, o sobrenadante foi recolhido e a ação da tripsina foi neutralizada com meio DMEM contendo $10 \%$ de soro fetal bovino, penicilina $(100 \mathrm{U} / \mathrm{mL})$, streptomicina $(100 \mu \mathrm{g} / \mathrm{mL})$, gentamicina $(40 \mu \mathrm{g} / \mathrm{mL})$ e anfotericina $B(2.5 \mu \mathrm{g} / \mathrm{mL})$. Ao fragmento original, foi novamente acrescentada a solução de tripsina/EDTA e o procedimento foi repetido 8 vezes. Os sobrenadantes foram reunidos e centrifugados a $1500 \mathrm{rpm}$ por $5 \mathrm{~min}$, e o sedimento com as células foi ressuspendido em meio de cultura próprio para queratinócitos, descrito a seguir.

O total de queratinócitos obtidos foi semeado sobre uma camada de sustentação (feeder-layer) de fibroblastos murinos irradiados. O conjunto queratinócitos/feeder-layer foi nutrido com meio de cultura constituído de DMEM e Ham F12 (proporção 2:1), 10\% de soro fetal bovino, penicilina $100 \mathrm{U} / \mathrm{mL}$, estreptomicina $100 \mu \mathrm{g} / \mathrm{mL}$, anfotericina B $2,5 \mu \mathrm{g} / \mathrm{mL}$, Lglutamina 4mM, adenina 0,18mM (Sigma-Aldrich), insulina $5 \mu \mathrm{g} / \mathrm{mL}$ (Sigma-Aldrich), hidrocortisona $0,4 \mu \mathrm{g} / \mathrm{mL}$ (Sigma-Aldrich), toxina colérica 0,1nM (Sigma-Aldrich) e triiodotironina 20pM (Sigma-Aldrich). A partir da primeira troca de meio, foi adicionado o Fator de Crescimento Epidérmico (EGF, Sigma-Aldrich), na concentração de $10 \mathrm{ng} / \mathrm{mL}$. As células foram mantidas a $37^{\circ} \mathrm{C}$, em atmosfera de $5 \%$ de $\mathrm{CO}_{2}$ até atingirem a subconfluência.

\section{Curvas de Proliferação Celular para Padronização da Camada de Sustentação}

Para verificar o potencial proliferativo dos fibroblastos murinos irradiados, foram comparadas suas curvas de proliferação com as de fibroblastos de mesma origem, porém não irradiados.

Um total de $2 \times 10^{5}$ células irradiadas e não-irradiadas foi semeado em frascos de cultura de $25 \mathrm{~cm}^{2}$ com $3 \mathrm{~mL}$ de meio DMEM, 10\% de soro fetal bovino, L-glutamina (2mM), aminoácidos não essenciais $(10 \mathrm{mM})$, penicilina $100 \mathrm{U} / \mathrm{mL}$, estreptomicina $100 \mu \mathrm{g} / \mathrm{mL}$ e

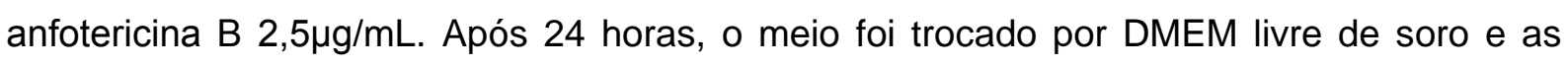
células foram incubadas por mais 24 horas. Para estimular o crescimento celular, o meio foi substituído por DMEM com 10\% de soro. Após 24, 72, 120 e 168 horas, as células de 3 frascos de fibroblastos murinos irradiados com $60 \mathrm{~Gy}, 80$ Gy de raio $X$ e não-irradiados foram lavadas com PBS a $37^{\circ} \mathrm{C}$ e incubadas com $1 \mathrm{~mL}$ de solução de tripsina 0,05\%/EDTA $0,02 \%$, também a $37^{\circ} \mathrm{C}$. Quando completamente separadas do soalho do frasco, foi coletada 
uma amostra para contagem do número de células. A tripsina foi inativada com $1 \mathrm{~mL}$ de meio DMEM com $10 \%$ de soro fetal bovino. O crescimento e a morfologia celular foram avaliados diariamente em microscópio invertido.

\section{Extração de RNA}

Para extração de RNA das amostras de tumores primários, foi utilizado o protocolo de extração sequencial padronizado no laboratório, que permite a separação de DNA e proteína, além de RNA.

As amostras foram adequadamente pulverizadas em cadinhos com nitrogênio líquido. Em seguida, foram adicionados $3 \mathrm{~mL}$ de Trizol (Gibco), que mantém a integridade do RNA enquanto promove a lise celular. O material foi, então, distribuído em três tubos de $1,5 \mathrm{~mL}$ e mantido à temperatura ambiente por $5 \mathrm{~min}$. Foram adicionados $200 \mu \mathrm{L}$ de clorofórmio gelado para cada $\mathrm{mL}$ de amostra em Trizol, os tubos foram homogeneizados por $30 \mathrm{~s}$ e incubados por $3 \mathrm{~min}$ à temperatura ambiente sendo, em seguida, acondicionados em gelo. As amostras foram centrifugadas a $12.000 \mathrm{~g}$, por $20 \mathrm{~min}$ a $4^{\circ} \mathrm{C}$, para separação da fase aquosa que contém RNA, da interfase branca e leitosa que contém principalmente DNA, e da fase orgânica, com proteína. A fase aquosa com RNA foi transferida para um novo tubo com $400 \mu \mathrm{L}$ de isopropanol gelado e $10 \mu \mathrm{g}$ de glicogênio e mantida por 15 min à temperatura ambiente. Após essa etapa de precipitação, as amostras foram centrifugadas a $12.000 \mathrm{~g}$, por 15 min a $4^{\circ} \mathrm{C}$ e o sobrenadante foi descartado por inversão. O sedimento foi lavado três vezes com $1 \mathrm{~mL}$ de etanol $75 \%$ gelado, agitado até se soltar do tubo e centrifugado a $7.500 \mathrm{~g}$ por 5 min a $4^{\circ} \mathrm{C}$. O tubo foi, então, seco sobre papel absorvente à temperatura ambiente, sendo posteriormente ressuspendido em 20-50 $\mu \mathrm{L}$ de água livre de nucleases (dependendo do tamanho do sedimento). As amostras foram colocadas em banho seco a $500 \mathrm{~g}$ por $10 \mathrm{~min}$ a $57^{\circ} \mathrm{C}$. Uma alíquota de RNA foi checada em gel de agarose $1,5 \%$ para avaliar sua qualidade e quantificado posteriormente. O RNA restante foi armazenado a $-80^{\circ} \mathrm{C}$ até seu uso. A síntese de cDNA foi realizada com o High Capacity cDNA Reverse Transcription Kit (Applied Biosystems, Forster City, CA, USA) para promover a transcrição reversa.

A fase orgânica obtida da extração do RNA foi utilizada para separação de DNA e proteínas segundo protocolos padronizados no laboratório. O material foi armazenado para uma possível utilização posterior.

Para as linhagens celulares, a extração de RNA seguiu protocolo padrão, com utilização de Trizol, e não o método sequencial.

\section{$\underline{\text { Reação em Cadeia da Polimerase pela Transcriptase Reversa (RT-PCR) }}$}

As amostras de RNA foram quantificadas no espectrofotômetro NanoDrop ND-1000 (Thermo Scientific, Wilmington, DE, USA). Segundo o resultado da quantificação, as 
amostras foram diluídas para uma concentração final de $1 \mathrm{ug} / \mu \mathrm{L}$. O material foi tratado com RQ1 RNase-Free DNase 1U/ul (Promega, Madison, WI, USA) para eliminação de DNA genômico, e submetido à reação de transcrição reversa com o High Capacity cDNA Reverse Transcription Kit (Applied Biosystems), que permite a inicialização da síntese da molécula de cDNA por random priming, oligo (dT) ou iniciadores específicos, utilizando a transcriptase reversa MultiScribe. As concentrações de reagentes utilizados na reação de transcrição reversa estão apresentadas na Tabela 3. As condições da reação de PCR foram: $25^{\circ} \mathrm{C}$ por $10 \mathrm{~min} ; 37^{\circ} \mathrm{C}$ por $120 \mathrm{~min} ; 85^{\circ} \mathrm{C}$ por $5 \mathrm{~min} ; 4^{\circ} \mathrm{C} \infty$.

Tabela 3. Concentrações de reagentes utilizados na reação de transcrição reversa. Água DEPC foi adicionada até atingir o volume final de $50 \mu \mathrm{l}$.

\begin{tabular}{ll} 
Reagentes & Concentrações/reação de $R T$ \\
\hline RNA & $1 \mathrm{ug} / \mu \mathrm{L}$ \\
\hline Random Primer & $10 \mathrm{X}-5 \mu \mathrm{L}$ \\
\hline dNTPs & $100 \mathrm{mM}-2 \mu \mathrm{L}$ \\
RT Buffer & $10 \mathrm{X}-5 \mu \mathrm{L}$ \\
MultiScribe & $50 \mathrm{U} / \mathrm{ul}-2,5 \mu \mathrm{L}$ \\
Água DEPC & Até $50 \mu \mathrm{L}$
\end{tabular}

\section{$\underline{\text { Reação em Cadeia da Polimerase (PCR) em Tempo Real }}$}

A PCR em tempo real foi a técnica utilizada para análise da expressão dos genes de interesse (KRT6A, KRT19, KLK8 e MSLN) em linhagens celulares, em tumores primários e suas margens cirúrgicas e em queratinócitos bucais humanos normais, obtidos após cultura primária.

As etapas da PCR foram realizadas no equipamento ABI Prism 7500 Fast Sequence Detection System (Appied Biosystems) com utilização do sistema de amplificação TaqMan e do reagente Taqman Universal PCR Master Mix, que contém todos os reagentes necessários para a reação. Esse sistema utiliza sondas marcadas com fluorescência de comprimentos de onda diferentes, o que permite a amplificação de dois genes (alvo e padrão interno) na mesma reação. Todas as sondas utilizadas para o desenvolvimento do projeto foram desenhadas pela própria empresa (Appied Biosystems) e marcadas com o fluoróforo FAM na extremidade 5'. Na extremidade 3', está ligada a molécula chamada "quencher", que produz a transferência de energia ressonante fluorescente, reduzindo assim a fluorescência do repórter quando a sonda está intacta. Durante a reação de PCR ocorre a 
hibridação dos iniciadores e da sonda e, durante a extensão dos iniciadores, a enzima Taq polimerase, por meio de sua atividade 5'-3' exonucleásica, cliva a sonda na sua extremidade 5' (Figura 5).

A fluorescência emitida pelo repórter é detectada continuamente para cada amostra, entre 520 e $670 \mathrm{~nm}$, sendo a intensidade de fluorescência diretamente proporcional à quantidade de cDNA da amostra. Os dados são traduzidos por um software específico e plotados em um gráfico que mostra a intensidade de fluorescência versus o número de ciclos. Quanto maior a quantidade de cDNA molde presente no início da reação, menor é o número de ciclos necessários para detecção de uma intensidade de fluorescência estatisticamente significante. Esse ponto é definido como limiar ou $\mathrm{C}_{t}$ e ocorre durante a fase exponencial de amplificação. Assim, cada amostra apresenta um valor de $C_{t}$ específico.

Os valores $C_{t}$ obtidos para os genes alvo nas linhagens celulares foram normalizados por um fator de normalização calculado para cada amostra pelo programa geNorm (http://medgen.ugent.be/ jvdesomp/genorm/) com base na média geométrica dos dados obtidos para os padrões internos GAPDH, ACTB, HPRT1 e BCR. O cDNA de queratinócitos bucais foi utilizado como controle para todas as linhagens. 

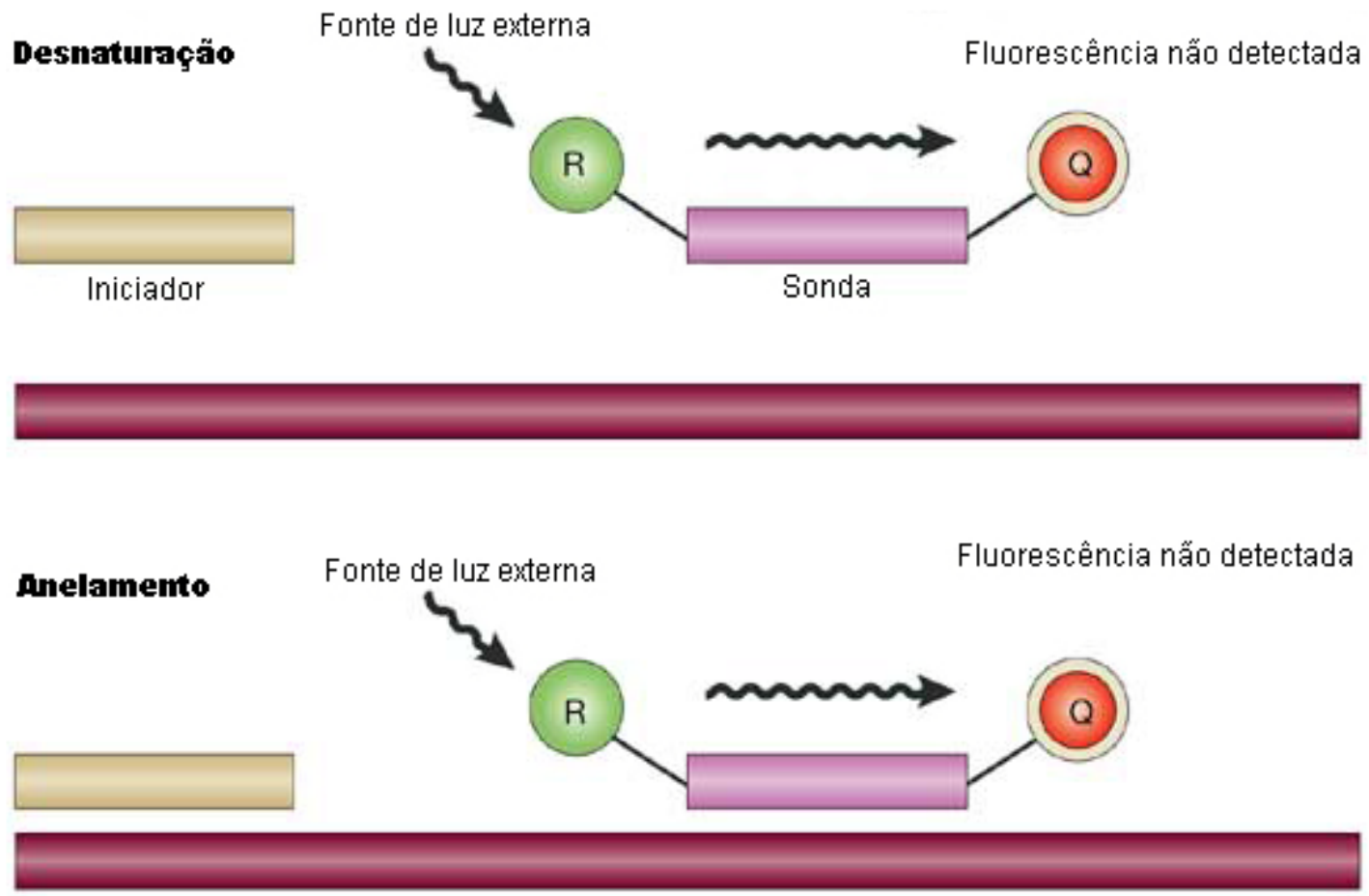

Fonte de luz externa

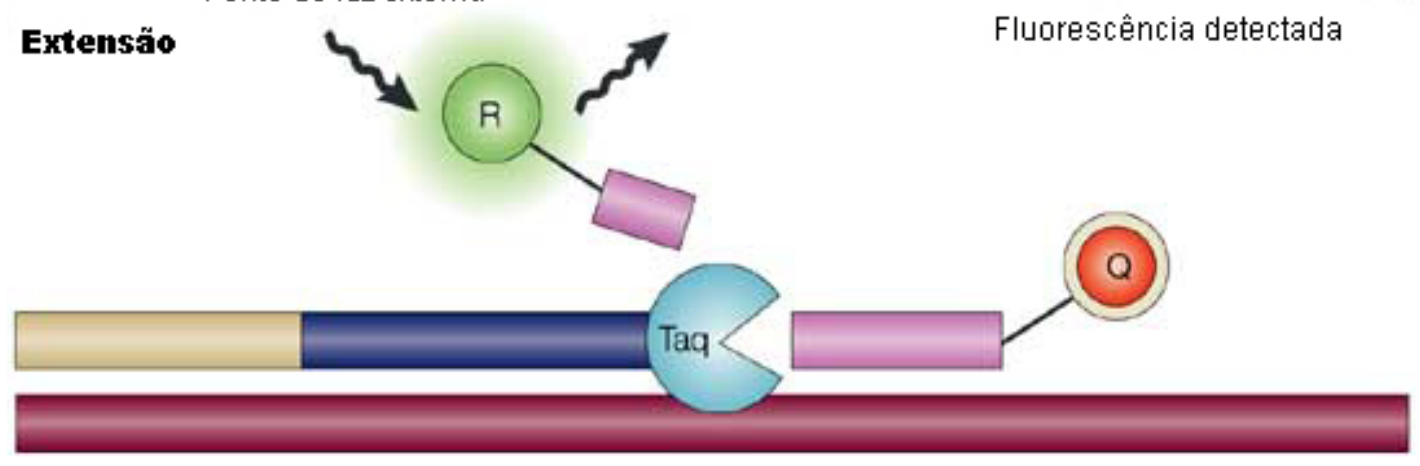

Figura 5. Esquema das etapas da PCR quantitativa. Adaptado de Koch (2004). $R=$ repórter, $\mathrm{Q}=$ quencher, $\mathrm{Taq}=$ Taq polimerase. 
Para as amostras de tumores primários, o programa geNorm calculou a estabilidade dos padrões internos GAPDH, ACTB, HPRT1 e BCR, comparando os valores de sua expressão em amostras de margens cirúrgicas com os valores dos respectivos tumores. Para essa análise, as amostras de margens cirúrgicas foram combinadas em quatro pools específicos para os sítios anatômicos laringe e cavidade oral (língua e soalho de boca) e para os grupos N+e NO. As amostras de tumores não foram combinadas em pools.

Não foi possível a obtenção de um fator de normalização para os tumores primários porque o programa geNorm, para cálculo da média geométrica, necessita de várias amostras para cada controle. Entretanto o estudo faz a comparação de um único tecido investigado com o tecido controle do mesmo paciente, ou seja, a margem cirúrgica.

As reações de PCR foram feitas em triplicata com um volume final de $10 \mu \mathrm{l}$, sendo $5 \mu \mathrm{l}$

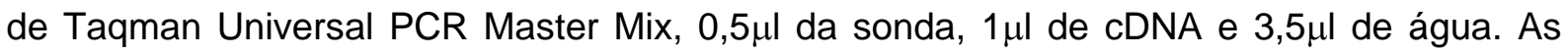
condições da ciclagem foram: $50^{\circ} \mathrm{C}-2 \mathrm{~min} ; 9^{\circ} \mathrm{C}-10 \mathrm{~min} ; 40$ ciclos de: $95^{\circ} \mathrm{C}-15$ s e $60^{\circ} \mathrm{C}$ -1 min.

\section{Determinação da Eficiência dos Iniciadores}

A eficiência de amplificação dos iniciadores foi avaliada pela construção de uma curvapadrão para cada gene investigado. Para os genes KRT19, MSLN, GAPDH, ACTB, HPRT1 e $B C R$, foram realizadas diluições em série de quantidades conhecidas de cDNA (20ng, 10ng, 5ng, 2,5ng, 1,25ng, 0,625 ng) da linhagem celular Hep-2 e, para os genes KRT6A e $K L K 8$, as diluições foram feitas a partir da linhagem celular FaDu. A partir da curva-padrão, foi calculada a equação da reta, permitindo a obtenção do valor de slope. O slope corresponde à inclinação da reta quando é analisada a variação do Ct dos transcritos alvo e do padrão interno em função do log de diferentes quantidades de cDNA. O cálculo da eficiência foi realizado segundo a fórmula: $E=10^{(-1 / \text { slope })}$.

\section{Cálculo da Expressão Relativa dos Genes KRT6A, KRT19, MSLN e KLK8}

No caso de linhagens celulares, a taxa relativa de expressão dos genes de interesse foi calculada com a fórmula abaixo, segundo o programa geNorm, na qual E=eficiência e $\Delta \mathrm{Ct}$ é a diferença entre o $\mathrm{Ct}$ da amostra controle e da amostra tumoral.

$$
\text { Taxa relativa de expressão }=\frac{\left(E_{\text {gene alvo }}\right)^{\Delta C t(\text { amostra controle - amostra tumoral) }}}{\text { Fator de Normalização }}
$$

Para as amostras de tumores primários, os valores de expressão dos genes de interesse foram calculados com a fórmula abaixo (Pfaffl, 2001), utilizando os valores do padrão interno selecionado pelo programa geNorm. 
Taxa relativa de expressão $=\frac{\left(E_{\text {gene alvo }}\right)^{\Delta \mathrm{Ct}(\text { amostra controle - amostra tumoral) }}}{\left(E_{\text {padrão interno }}\right)^{\Delta \mathrm{Ct}(\text { amostra controle - amostra tumoral })}}$

Foram considerados diferencialmente expressos os transcritos que exibiram expressão relativa $\geq 3.0$ ou $\leq-3.0$ em relação ao tecido controle, após a transformação dos valores para logaritmo de base 3. Dessa forma, um valor de expressão relativa igual $a+1$ equivale a um aumento de expressão de 3 vezes, e um valor de -1 equivale a uma diminuição de expressão de 3 vezes.

\section{Análise Estatística}

A análise dos components principais (Bergkvist et al., 2010) foi utilizada para verificar possíveis associações entre as variáveis sexo, idade, consumo de tabaco, consumo de álcool, TNM, estádio, diferenciação histológica, infiltração vascular sanguínea, infiltração linfática, invasão perineural, infiltrado inflamatório peri-tumoral e óbito, com o aumento/diminuição de expressão dos genes estudados, de acordo com o sítio anatômico. Por definição matemática, os componentes principais são extraídos em sucessiva ordem de importância, procurando explicar a informação (variação) nos dados. Essa técnica é muito eficiente em separar efeitos sistemáticos de ruídos.

Também foi utilizado o test $t$ de Student não-pareado para verificar a significância dos dados de expressão dos genes entre as amostras NO e N+ de cada sítio. Essa expressão foi calculada com a fórmula $2^{-\Delta \mathrm{Ct}}$, na qual $\Delta \mathrm{Ct}=\mathrm{Ct}_{\text {gene alvo }}-\mathrm{Ct}_{\mathrm{GAPDH}}$, para cada amostra. Essa abordagem constitui uma alternativa para verificar a variação de expressão de cada gene entre as amostras tumorais, sem a comparação com as respectivas margens. 


\section{RESULTADOS}

\section{Casuística}

Foram analisadas 63 pares de amostras de carcinomas epidermóides de cabeça e pescoço, que incluíram 29 pares de tumor-margem procedentes de carcinoma de laringe (15 NO e $14 \mathrm{~N}+$ ), 10 pares de carcinoma de língua (4 N0 e $6 \mathrm{~N}+$ ) e 24 de soalho de boca (14 N0 e $10 \mathrm{~N}+$ ); 56 pacientes eram do sexo masculino e 7 do sexo feminino, com idades variando de 39 a 79 anos (média $=56,5$ anos); 60 referiram exposição ao tabaco, sendo 14 exfumantes; 56 pacientes faziam uso de álcool, mas 15 haviam abandonado o hábito etílico; 56 relataram exposição ao fumo e ao álcool e apenas 3 pacientes nunca fumaram e não eram etilistas. A classe TNM mais freqüente foi a T4NOMO (Tabela 4).

\section{Curvas de Proliferação Celular para Padronização da Camada de Sustentação}

Após irradiação de fibroblastos murinos (3T3-Swiss albino) com doses de 60 e 80 Gy de raio $X$, foram construídas curvas de proliferação celular para avaliação da eficiência das doses sobre a inibição de proliferação. Foi observada uma freqüência elevada (62,5\% para a dose de 60Gy e 61,25 para a dose de 80Gy) de morte das células irradiadas no tempo de 24 horas e, só após esse período, os fibroblastos entraram em processo de duplicação. Para ambas as doses de radiação, ocorreu um pico de replicação celular entre 24 e 72 horas, mas o crescimento dos fibroblastos irradiados com 60Gy foi significantemente maior. Entre 72 e 120 horas, o número de células irradiadas com 60Gy teve um pequeno aumento, ao contrário daquelas irradiadas com 80Gy. Entre 120 e 168 horas, houve morte celular em ambas as condições (Figuras 6). Em função desses resultados, os fibroblastos irradiados com 60Gy foram escolhidos para a camada de sustentação em culturas de queratinócitos.

\section{Padronização da Cultura Primária de Queratinócitos}

Após desagregação enzimática da camada de queratinócitos bucais humanos normais, as células foram cultivadas sobre a camada de sustentação de fibroblastos. As colônias de queratinócitos foram visualizadas após dez dias de cultivo. À medida que as colônias cresciam, ocorria a morte dos elementos da camada de sustentação (Figura 7). 
Tabela 4. Frequência dos parâmetros sexo, idade, exposição a fumo e álcool, sítio primário e classificação das lesões em 63 pacientes portadores de carcinomas epidermóides de cabeça e pescoço segundo tamanho $(T)$, comprometimento de linfonodos (N1-3) ou não N0), e ausência de metástases (M0) ou não (M1-X).

\begin{tabular}{llc}
\hline \multicolumn{1}{c}{ Parâmetros } & \multicolumn{1}{c}{ Grupos } & Total de pacientes (\%) \\
\hline Sexo & Masculino & $56(88,9 \%)$ \\
& Feminino & $7(11,1 \%)$ \\
Idade* & $\geq 40$ & $61(96,8 \%)$ \\
Fumante & $<40$ & $2(3,2 \%)$ \\
& Sim & \\
& No passado & $46(73,0 \%)$ \\
Etilista & Não & $14(22,2 \%)$ \\
& Sim & $3(4,8 \%)$ \\
Sítio Primário & No Passado & $41(65,1 \%)$ \\
& Não & $15(23,8 \%)$ \\
& Língua (C02) & $7(11,1 \%)$ \\
& Soalho de boca (C04) & $10(15,9 \%)$ \\
Classificação & Laringe (C32) & $24(38,1 \%)$ \\
& & $29(46,0 \%)$ \\
& T1 & $4(6,4 \%)$ \\
& T2 & $16(25,4 \%)$ \\
& T3 & $12(19,0 \%)$ \\
& T4 & $31(49,2 \%)$ \\
& N0 & $33(52,4 \%)$ \\
& N1 & $4(6,35 \%)$ \\
& N2 & $22(34,9 \%)$ \\
& N3 & $4(6,35 \%)$ \\
& M0 & $53(84,1 \%)$ \\
& M1-X & $10(15,9 \%)$ \\
& &
\end{tabular}


A

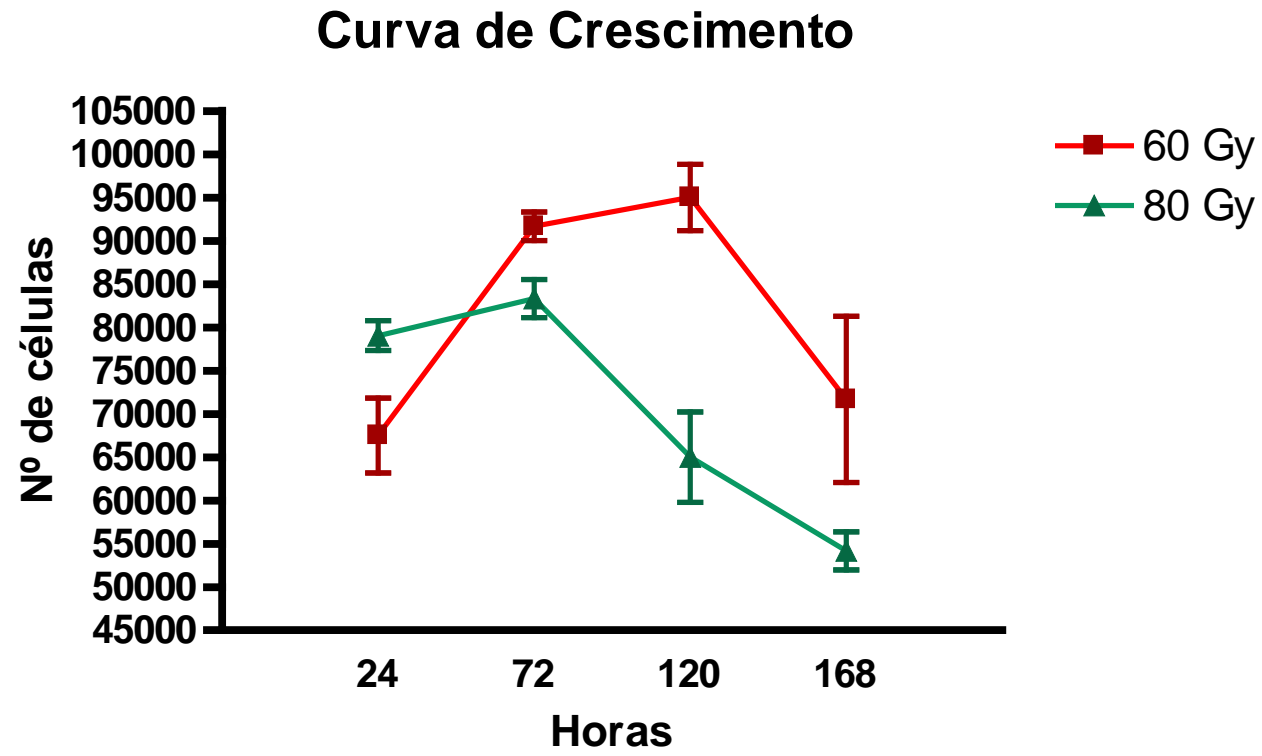

B

\section{Curva de Crescimento}

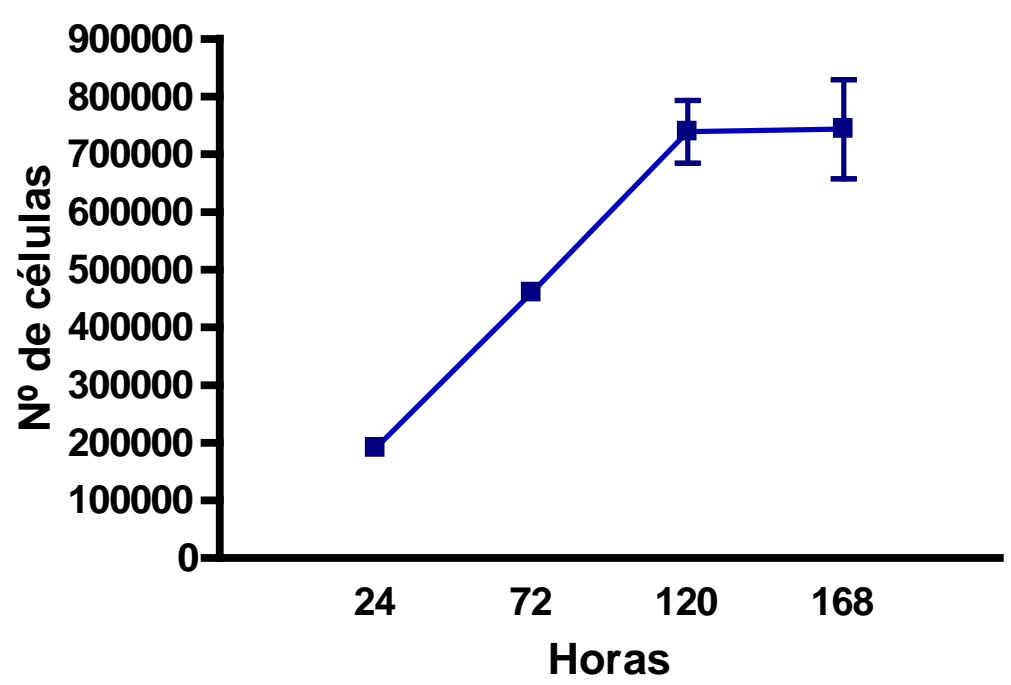

Figura 6. Curvas de crescimento de fibroblastos murinos (3T3-Swiss albino) (A) após irradiação com doses de 60 e 80- Gy e (B) sem irradiação. 


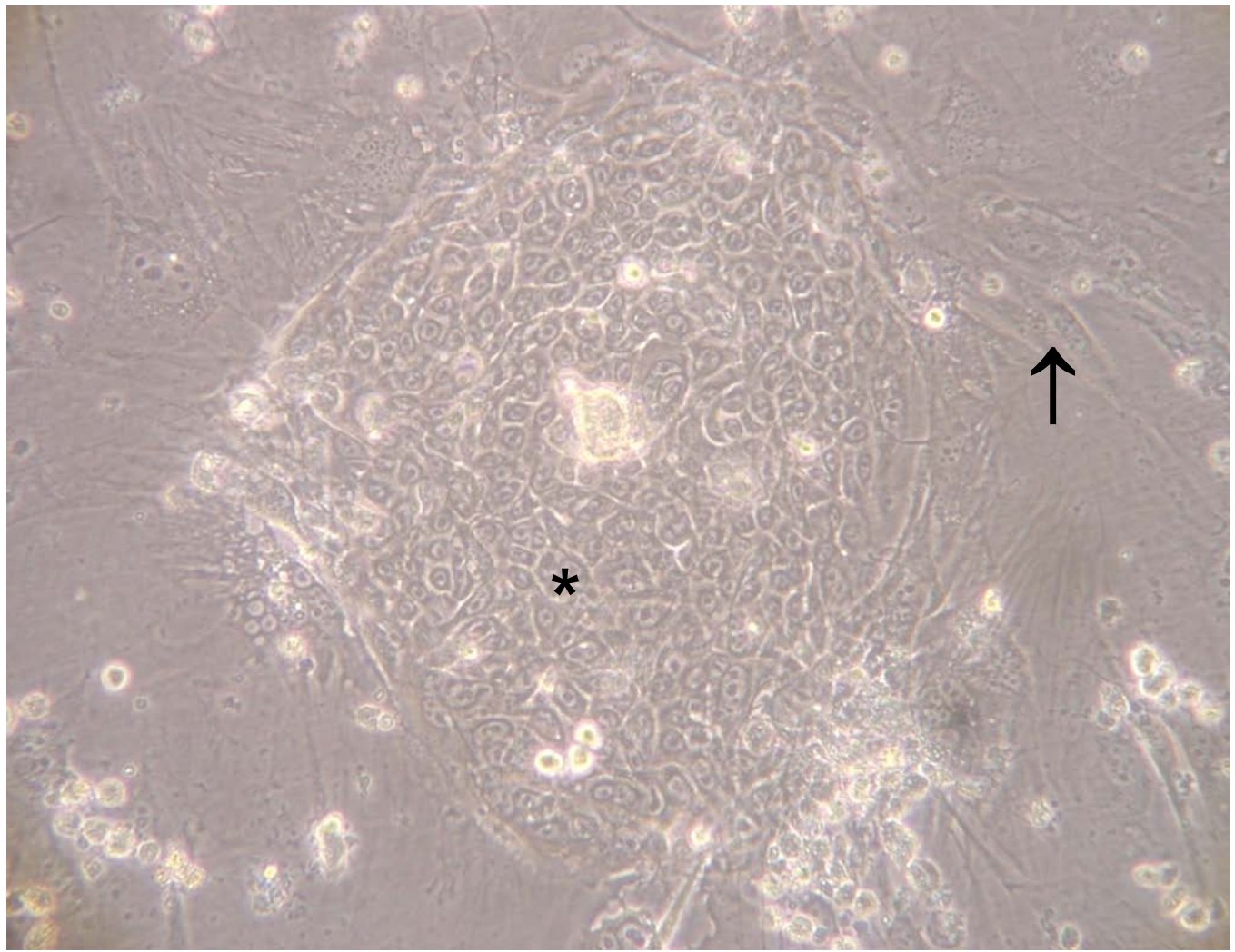

Figura 7. Aspecto morfológico de queratinócitos primários de cavidade oral cultivados sobre camada de sustentação de fibroblastos murinos irradiados. Culturas subconfluentes, observadas em aumento de 100x. Seta. Feeder-layer remanescente. Asterisco (*). Colônia de queratinócitos.

\section{Curvas-Padrão}

As curvas-padrão para os genes de interesse KRT6A, KRT19, MSLN e KLK8 e para os padrões internos BCR, $\beta$-actina, GAPDH e HPRT1 (Figura 8) foram realizadas utilizando diluições de cDNA das linhagens celulares Hep-2 e FaDu. Os valores de slope (coeficiente angular da reta) e da eficiência dos iniciadores, segundo a fórmula: $E=10^{(-1 / \text { slope })}$, estão apresentados na Tabela 5.

Foi verificada uma baixa variação dos valores de eficiência das sondas utilizadas (a diferença entre o maior valor de eficiência observado e o menor foi de apenas 0,04). Todos os valores foram próximos de 100\% (o valor 2 equivale a uma eficiência de 100\%), o que indica uma excelente qualidade das sondas. 
A) $K R T 6 A$

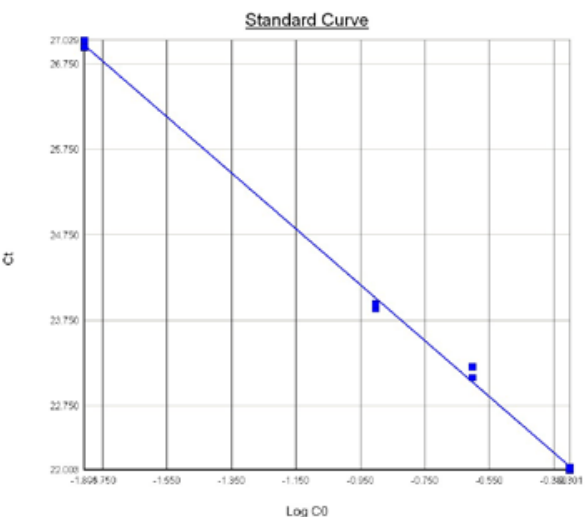

C) $M S L N$

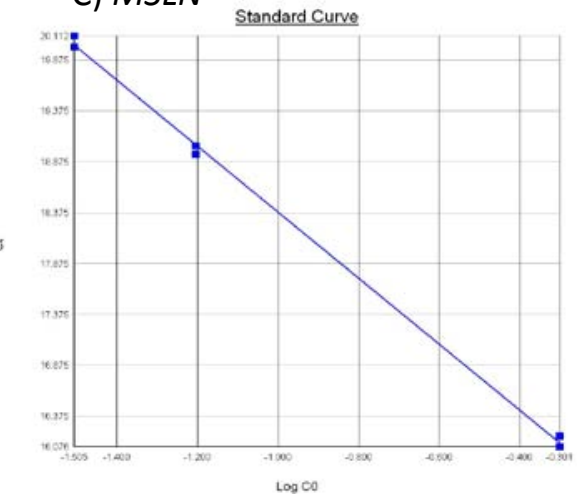

E) GAPDH

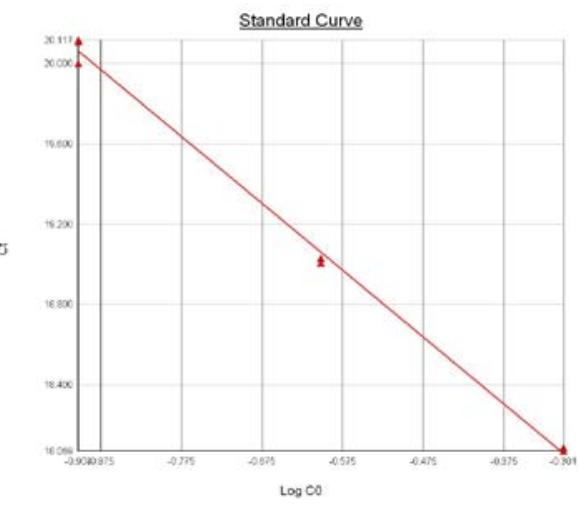

G) HPRT1

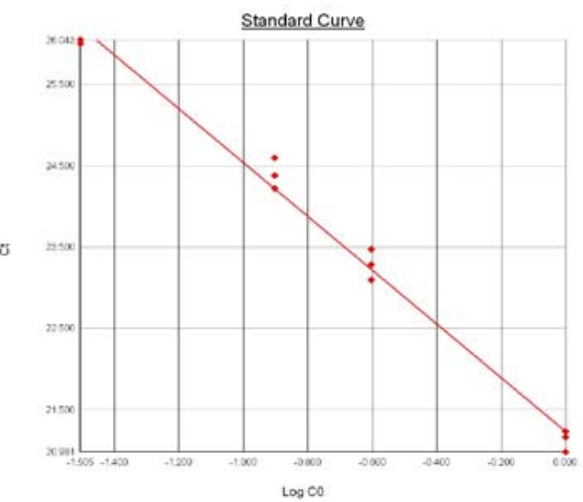

B) $K R T 19$

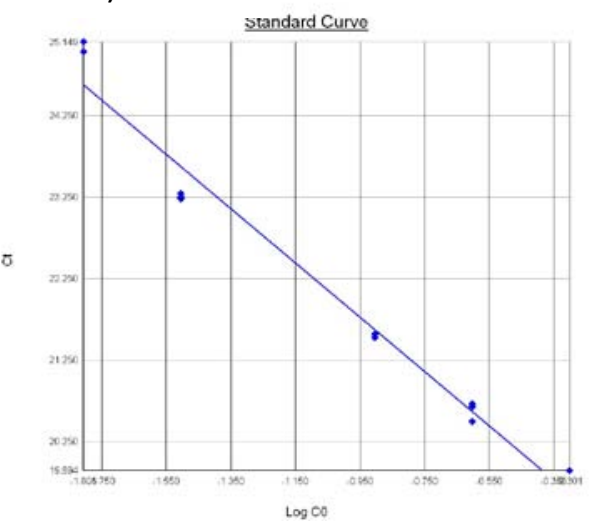

D) $K L K 8$

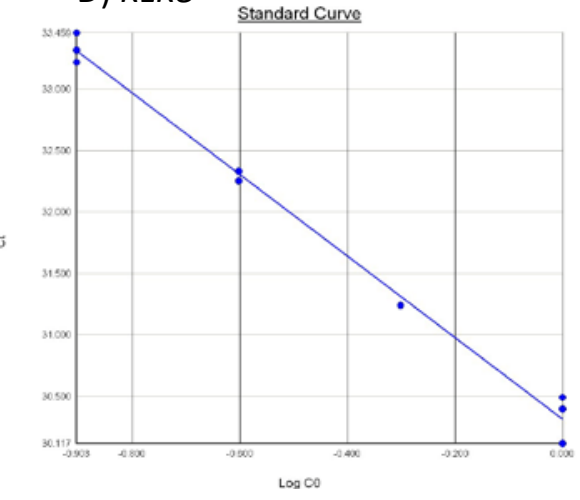

F) b-actina

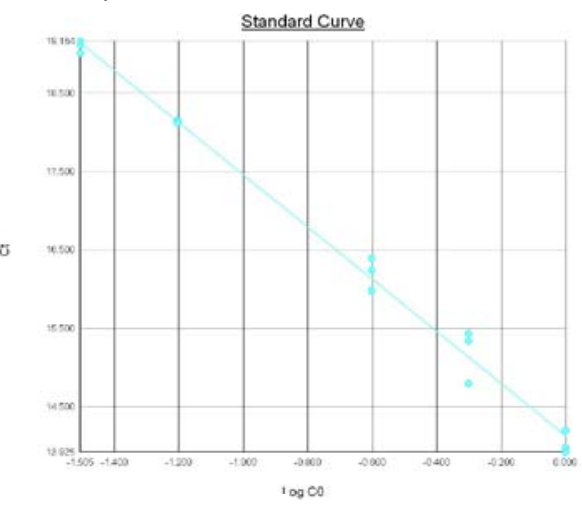

H) $B C R$

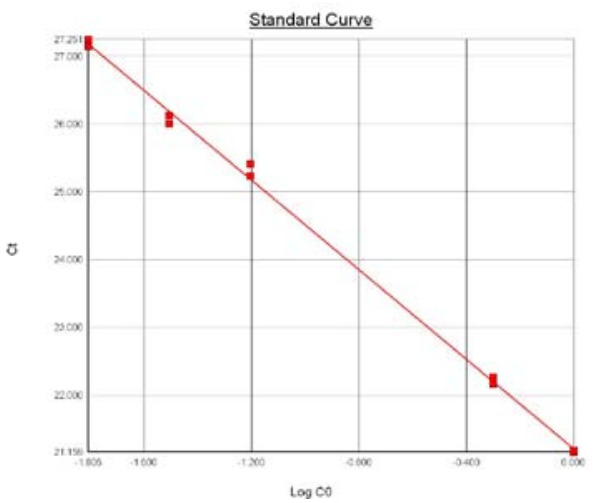

Figura 8. Gráficos ilustrando as curvas-padrão dos genes alvo $\operatorname{KRT6A}(\mathrm{A}), \operatorname{KRT19}(\mathrm{B})$, $\operatorname{MSLN}(\mathrm{C}), K L K 8(\mathrm{D})$ e dos padrões internos GAPDH (E), $\beta$-actina (F), HPRT1 (G), BCR (H). 
Tabela 5. Valores do coeficiente angular da reta (slope) e da eficiência $\left(10^{-1 / s l o p e}\right)$ dos iniciadores para os genes de interesse (KRT6A, KRT19, MSLN, KLK8) e para os padrões internos (GAPDH, $\beta$-actina, HPRT1, BCR).

\begin{tabular}{|c|c|c|c|}
\hline \multicolumn{1}{|c|}{ Gene } & $-3,273659$ & 0,305 & 2,02 \\
\hline KRT6A & $-3,327752$ & 0,300 & 1,99 \\
\hline KRT19 & $-3,242906$ & 0,308 & 2,03 \\
\hline MSLN & $-3,321895$ & 0,301 & 2,00 \\
\hline KLK8 & $-3,328197$ & 0,300 & 1,99 \\
\hline GAPDH & $-3,326278$ & 0,300 & 1,99 \\
\hline$\beta$-actina & $-3,310846$ & 0,302 & 2,00 \\
\hline HPRT1 & $-3,308262$ & 0,302 & 2,00 \\
\hline BCR & & & \\
\hline
\end{tabular}

\section{Linhagens Celulares}

Foi analisada a expressão dos genes de interesse KRT6A, KRT19, MSLN e KLK8 e dos genes constitutivos $\beta$-actina, BCR, GAPDH e HPRT1 nas quatro linhagens celulares (FaDu, Hep-2, SCC9, UM-SCC-38) e nos queratinócitos bucais humanos normais para cálculo do fator de normalização. O programa geNorm concluiu que o gene $B C R$ não é um bom normalizador por não apresentar estabilidade adequada. Por esse motivo, esse gene foi excluído das análises (Tabela 6).

Após a obtenção do fator de normalização, foi calculada a expressão relativa dos genes de interesse pela fórmula referida em Materiais e Métodos, utilizando os queratinócitos normais como controle. A Tabela 7 mostra os valores obtidos. Esses valores, em logaritmo de base 3 para os genes de interesse KRT6A, KRT19, MSLN e KLK8, estão apresentados na Tabela 8 e na Figura 9.

Como pode ser observado, os genes KRT6A e KLK8 não são expressos nas células Hep-2 e exibem baixos níveis nas demais linhagens, independentemente da duração do cultivo. Um padrão paralelo, mas não idêntico, ocorreu com os transcritos de KRT19, que mostrou redução em todas as linhagens e em todos os tempos de cultivo, exceto em UMSCC-38. No caso de MSLN, o perfil foi variável, com níveis reduzidos em UM-SCC-38 e nas culturas de 24 horas de SCC9. Por outro lado, exibiu elevação de expressão em FaDu e Hep-2 com a progressão do cultivo. Em resumo, todos os genes apresentaram ausência ou diminuição de expressão nas linhagens estudadas em comparação com queratinócitos bucais humanos normais, com exceção da mesotelina, que apresentou um padrão irregular de expressão. 
Tabela 6. Resultados obtidos no cálculo do fator de normalização pelo programa geNorm para os transcritos dos genes GAPDH, $\beta$-actina e HPRT1 nas linhagens celulares FaDu, Hep-2, SCC9, UM-SCC-38 cultivadas por 24, 48 e 72 horas em relação aos queratinócitos bucais humanos normais (BHK).

\begin{tabular}{|c|c|c|c|c|c|}
\hline & GAPDH & B-actina & HPRT1 & Normalisation & Factor \\
\hline BHK & $1,00 \mathrm{E}+00$ & $1,00 \mathrm{E}+00$ & $1,00 \mathrm{E}+00$ & \begin{tabular}{|r|}
1,8857 \\
\end{tabular} & \\
\hline Hep2 24h & $8,96 \mathrm{E}-01$ & $7,65 \mathrm{E}-01$ & $1,10 \mathrm{E}+00$ & 1,7182 & \\
\hline Hep2 48h & $3,89 \mathrm{E}-01$ & $1,54 \mathrm{E}-01$ & $5,09 \mathrm{E}-01$ & 0,5888 & \\
\hline Hep2 72h & $5,29 \mathrm{E}-02$ & $2,66 \mathrm{E}-02$ & $2,52 \mathrm{E}-02$ & 0,0619 & \\
\hline Fadu $24 \mathrm{~h}$ & $8,36 \mathrm{E}-01$ & $1,13 \mathrm{E}+00$ & $1,59 \mathrm{E}+00$ & 2,1630 & \\
\hline Fadu 48h & $3,80 \mathrm{E}-01$ & $2,89 \mathrm{E}-01$ & $4,05 \mathrm{E}-01$ & 0,6686 & \\
\hline Fadu $72 \mathrm{~h}$ & $6,35 \mathrm{E}-01$ & $5,03 \mathrm{E}-01$ & $1,07 \mathrm{E}+00$ & 1,3172 & \\
\hline SCC9 24h & $4,54 \mathrm{E}-01$ & $1,14 \mathrm{E}+00$ & $2,50 \mathrm{E}+00$ & 2,0553 & \\
\hline SCC9 48h & $4,48 \mathrm{E}-01$ & $5,97 \mathrm{E}-01$ & $1,44 \mathrm{E}+00$ & 1,3721 & \\
\hline SCC $72 \mathrm{~h}$ & 4,33E-01 & $5,29 \mathrm{E}-01$ & $1,30 \mathrm{E}+00$ & 1,2606 & \\
\hline UM-SCC-38 24h & $5,92 \mathrm{E}-01$ & $3,83 \mathrm{E}-01$ & $7,30 \mathrm{E}-01$ & 1,0345 & \\
\hline UM-SCC-38 48h & $1,11 \mathrm{E}+00$ & $4,20 \mathrm{E}-01$ & $4,90 \mathrm{E}-01$ & 1,1541 & \\
\hline UM-SCC-38 72h & $5,69 \mathrm{E}-01$ & $3,56 \mathrm{E}-01$ & $8,45 \mathrm{E}-01$ & 1,0466 & \\
\hline$M<1,5$ & 0,896 & 0,666 & 0,789 & & \\
\hline
\end{tabular}

Tabela 7. Valores de expressão relativa dos genes alvo KRT6A, KRT19, MSLN e $K L K 8$ nas linhagens celulares FaDu, Hep-2, SCC9, UM-SCC-38 cultivadas por 24, 48 e 72 horas, utilizando queratinócitos bucais normais como controle.

\begin{tabular}{|c|c|c|c|c|}
\hline \multicolumn{2}{|c}{ KRT6A } & KRT19 & MSLN & KLK8 \\
\hline Hep2 24h & Não expressa & $7,01 \mathrm{E}-05$ & 2,588989 & Não expressa \\
\hline Hep2 48h & Não expressa & 0,000239 & 14,29363 & Não expressa \\
\hline Hep2 72h & Não expressa & 0,001235 & 84,8128 & Não expressa \\
\hline Fadu 24h & 0,000145 & 0,020972 & 3,441774 & $7,67 \mathrm{E}-05$ \\
\hline Fadu 48h & 0,000132 & 0,057479 & 8,977142 & 0,000118 \\
\hline Fadu 72h & $2,29 \mathrm{E}-05$ & 0,02266 & 13,3684 & 0,000104 \\
\hline SCC9 24h & 0,003448 & 0,001129 & 0,26138 & 0,000332 \\
\hline SCC9 48h & 0,006767 & 0,002084 & 0,778368 & 0,001262 \\
\hline SCC9 72h & 0,008039 & 0,002768 & 0,653351 & 0,002199 \\
\hline UM-SCC-38 24h & 0,222055 & 0,928205 & 0,032675 & 0,043016 \\
\hline UM-SCC-38 48h & 0,039633 & 0,670183 & 0,021973 & 0,139562 \\
\hline UM-SCC-38 72h & 0,023897 & 0,434244 & 0,041229 & 0,111811 \\
\hline
\end{tabular}


Tabela 8. Valores de expressão relativa em logaritmo de base 3 dos genes alvo KRT6A, KRT19, MSLN e KLK8 nas linhagens celulares FaDu, Hep-2, SCC9, UM-SCC-38 cultivadas por 24, 48 e 72 horas.

\begin{tabular}{|c|c|c|c|c|}
\hline & KRTGA & KRT19 & MSLN & $K L K 8$ \\
\hline Hep2 24h & Não expressa & $-8,70753$ & 0,865881 & Não expressa \\
\hline Hep2 48h & Não expressa & $-7,58871$ & 2,421067 & Não expressa \\
\hline Hep2 72h & Não expressa & $-6,09524$ & 4,041869 & Não expressa \\
\hline Fadu 24h & $-8,04429$ & $-3,5177$ & 1,125044 & $-8,62451$ \\
\hline Fadu 48h & $-8,12933$ & $-2,59994$ & 1,997685 & $-8,23208$ \\
\hline Fadu $72 \mathrm{~h}$ & $-9,72398$ & $-3,44724$ & 2,360154 & $-8,35118$ \\
\hline SCC9 24h & $-5,16109$ & $-6,17751$ & $-1,22134$ & $-7,29095$ \\
\hline SCC9 48h & $-4,54725$ & $-5,61922$ & $-0,22807$ & $-6,07578$ \\
\hline SCC9 72h & $-4,39045$ & $-5,36096$ & $-0,38744$ & $-5,57062$ \\
\hline UM-SCC-38 24h & $-1,36976$ & $-0,06782$ & $-3,11407$ & $-2,86378$ \\
\hline UM-SCC-38 48h & $-2,93833$ & $-0,36428$ & $-3,47523$ & $-1,79249$ \\
\hline UM-SCC-38 72h & $-3,39883$ & $-0,75927$ & $-2,9024$ & $-1,99429$ \\
\hline
\end{tabular}
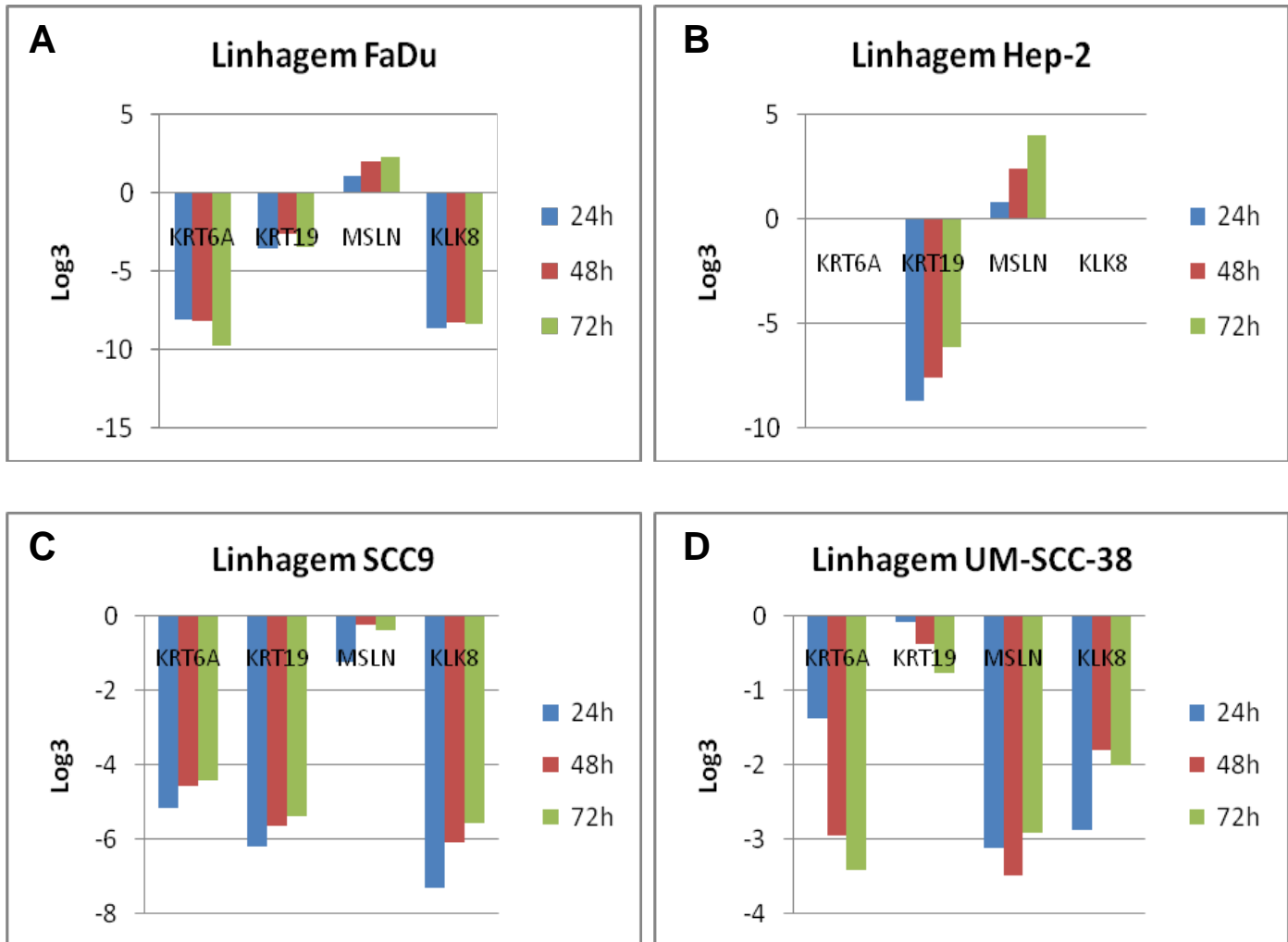

Figura 9. Valores de expressão relativa em logaritmo de base 3 dos genes alvo KRT6A, KRT19, MSLN e KLK8 nas linhagens celulares (A) FaDu, (B) Hep-2, (C) SCC9 e (D) UM-SCC-38 cultivadas por 24,48 e 72 horas. 


\section{Seleção do Padrão Interno para Tumores Primários}

O programa geNorm selecionou, entre os padrões internos GAPDH, ACTB, HPRT1 e $B C R$, dois genes com estabilidade adequada para normalização dos valores de expressão de genes alvo em tumores primários. Como esses dois genes eram diferentes para cada sítio anatômico, exceto o GAPDH, esse gene foi utilizado no cálculo da expressão relativa para o grupo todo (Tabela 9).

Os valores médios de Cts dos padrões internos obtidos de pools de amostras de margens cirúrgicas e de amostras individuais de carcinomas primários e suas margens estão apresentados na Tabela 1 do Anexo 1.

Tabela 9. Genes selecionados pelo programa geNorm como mais estáveis para utilização na normalização da expressão gênica.

\begin{tabular}{|l|c|}
\multicolumn{1}{|c|}{ Sítio anatômico } & Genes Selecionados \\
\hline Língua/Soalho de boca N0 & GAPDH e $\beta$-actina \\
\hline Língua/Soalho de boca N+ & GAPDH e HPRT1 \\
\hline Laringe NO & GAPDH e $\beta$-actina \\
\hline Laringe N+ & GAPDH e $\beta$-actina \\
\hline
\end{tabular}




\section{Expressão do gene $K R T 6 A$}

Os valores médios de Ct e de expressão relativa do gene $K R T 6 A$, bem como o $\log _{3}$ da expressão relativa, estão apresentados na Tabela 2 do Anexo 1.

Os resultados observados em carcinomas de língua, soalho de boca e laringe mostraram que, em média, não houve alteração de expressão do gene $K R T 6 A$ em relação às margens cirúrgicas, embora algumas amostras tenham exibido um aumento ou uma diminuição significativa de níveis de transcritos (Figura 10). De acordo com a presença/ausência de metástases linfonodais, não foi verificada diferença entre os grupos $\mathrm{N}+$ e NO nos carcinomas epidermóides de língua, com 1 amostra N0 e $1 \mathrm{~N}+$ exibindo aumento de expressão, e 1 N0 e 2 N+ com diminuição de expressão (Figura 10 e Tabela 2 do Anexo 1).

Nas amostras de soalho de boca, 8 amostras revelaram aumento de expressão, sendo $4 \mathrm{~N}+$ e 4 No, e 4 diminuição dos níveis dos transcritos, 1 No e $3 \mathrm{~N}+$ (Figura 10 e Tabela 2 do Anexo 1).

Nos carcinomas de laringe, os resultados também foram heterogêneos: 6 amostras N0 e $5 \mathrm{~N}+$ com aumento, e 4 No e $2 \mathrm{~N}+$ com diminuição de expressão (Figura 10 e Tabela 2 do Anexo 1).

A análise dos componentes principais não revelou associação entre os parâmetros analisados e a expressão diferencial da queratina $6 \mathrm{~A}$. $\mathrm{O}$ teste t de Student não identificou diferença significativa entre os valores de expressão dos tumores NO e N+ em cada sito anatômico. 
A

KRT6A

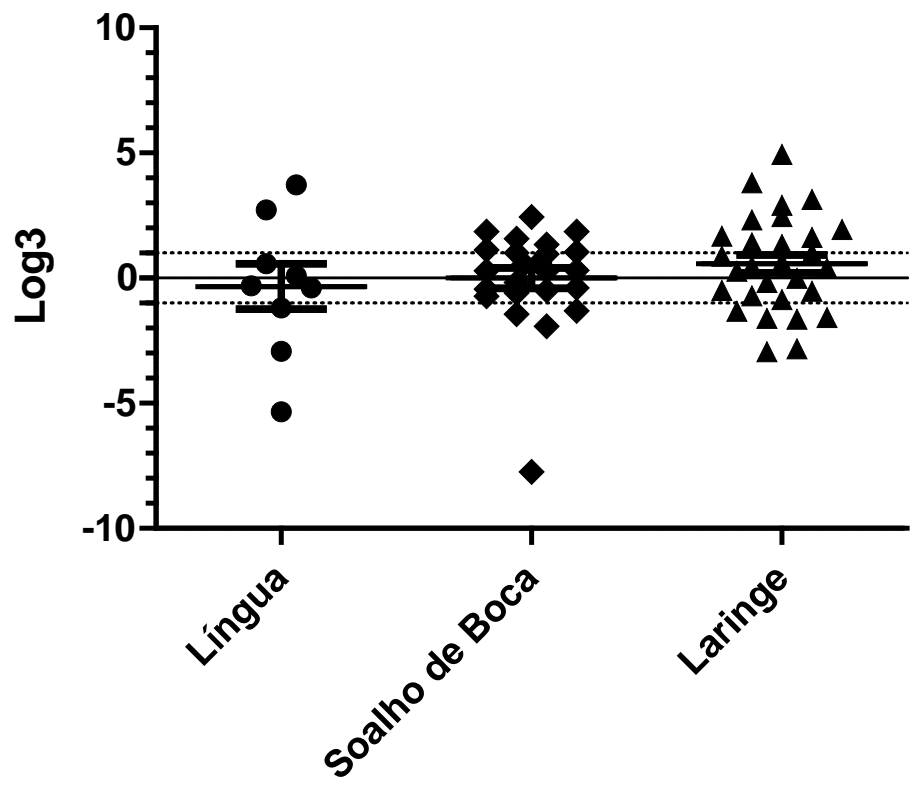

B

KRT6A

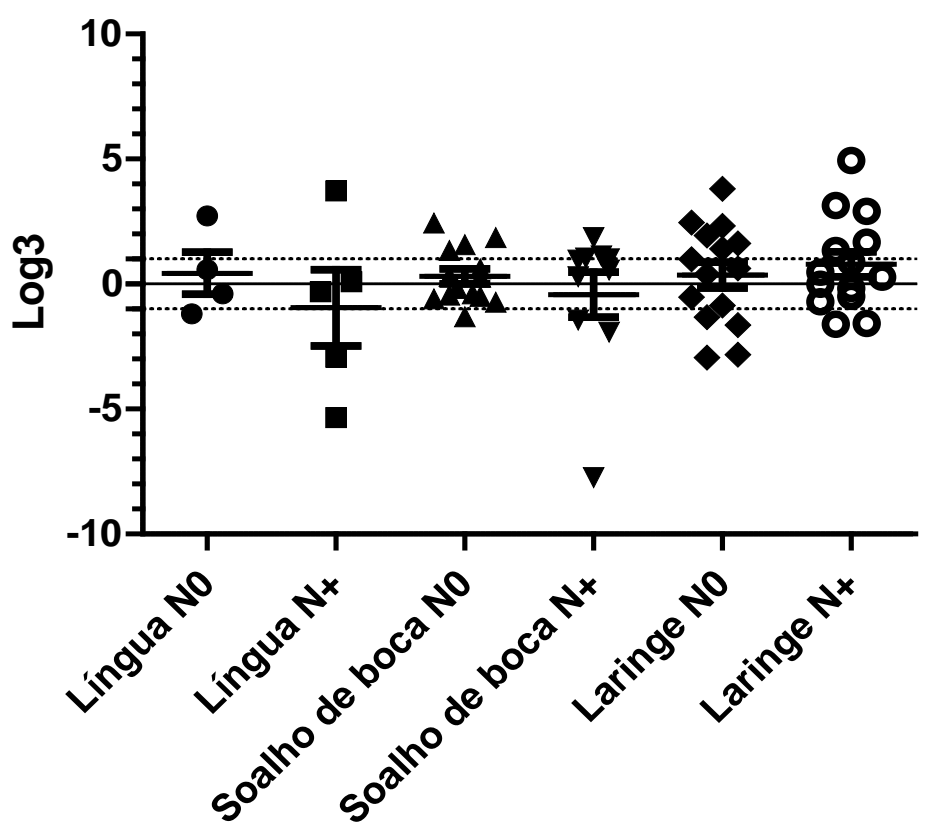

Figura 10. Valores de expressão relativa apresentados em $\log _{3}$, referentes à análise do gene $K R T 6 A$ em amostras $(A)$ de língua, soalho de boca $e$ laringe e (B) NO e N+ de cada sítio anatômico. 


\section{Expressão do gene KRT19}

Os valores médios de Ct e de expressão relativa do gene $K R T 19$, bem como o $\log _{3}$ da expressão relativa, estão apresentados na Tabela 3 do Anexo 1.

Para esse gene, das 63 amostras analisadas, 30 apresentaram redução e 13 aumento de níveis de transcritos (Figura 11). Considerando os casos de carcinoma de língua, 1 amostra mostrou aumento de expressão, sendo que o paciente não possuía metastáses linfonodais, e 3 diminuição de expressão, das quais 1 amostra é N0 e 2 são N+ (Figura 11 e Tabela 3 do Anexo 1).

Foi verificado, em de soalho de boca, 7 amostras com elevação dos níveis dos transcritos (6 amostras N0 e 1 amostra $\mathrm{N}+$ ) e 10 amostras com diminuição de expressão (5 amostras No e $5 \mathrm{~N}+$ ) (Figura 11 e Tabela 3 do Anexo 1).

Os carcinomas de laringe mostraram um padrão mais homogêneo, com tendência à redução de níveis de transcritos: 2 amostras N0 e $2 \mathrm{~N}+$ com aumento, e $9 \mathrm{NO}$ e 8N+ com diminuição de expressão (Figura 11 e Tabela 3 do Anexo 1). Sem levar em conta a presença de metástase, das 29 amostras de laringe analisadas, 17 tiveram redução e apenas 4 tiveram aumento de expressão (Figura 11).

Em resumo, as amostras de língua $\mathrm{N}+$, laringe $\mathrm{NO}$ e $\mathrm{N}+$ mostraram diminuição significativa de expressão do KRT19.

A análise dos componentes principais não revelou associação entre os parâmetros analisado e a expressão diferencial da queratina 19. O teste t de Student não identificou diferença significativa entre os valores de expressão dos tumores $\mathrm{N} 0 \mathrm{e} \mathrm{N}+$, exceto para soalho de boca, que mostraram-se estatisticamente diferentes $(p=0,03)$. 
A

KRT19

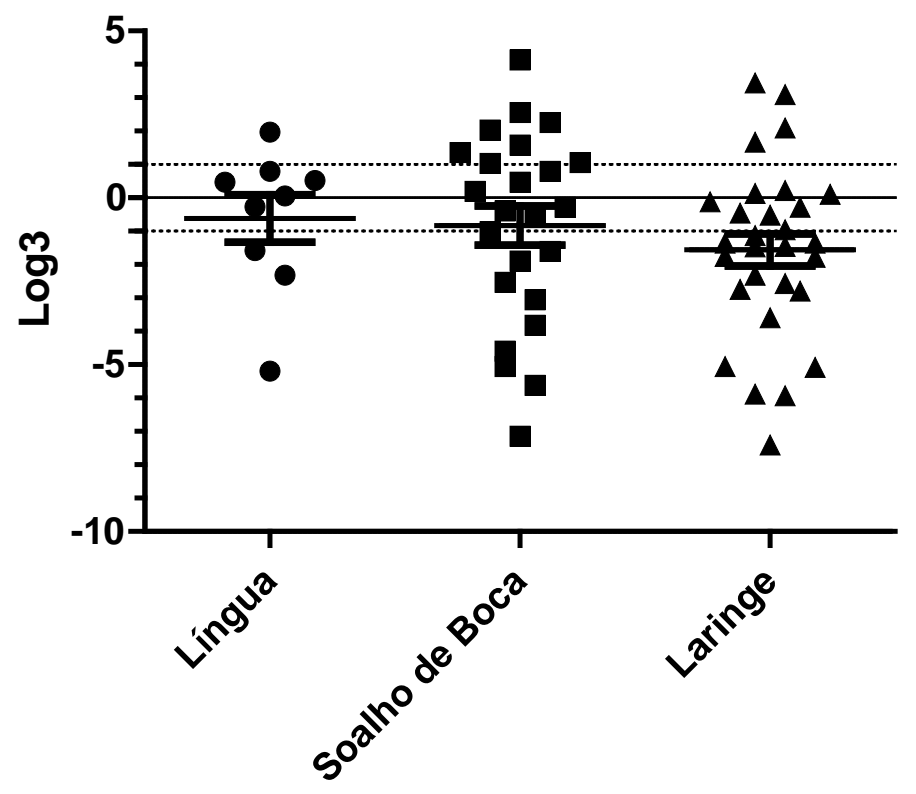

B

KRT19

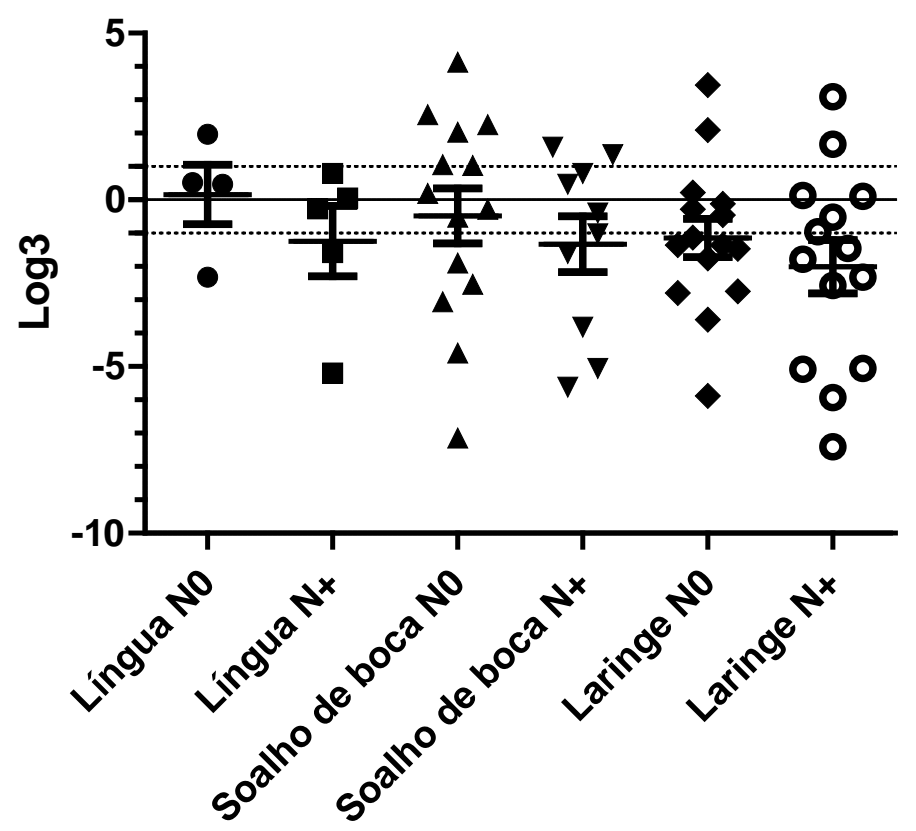

Figura 13. Valores de expressão relativa apresentados em $\log _{3}$, referentes à análise do gene KRT19 em amostras $(\mathrm{A})$ de língua, soalho de boca e laringe e (B) NO e N+ de cada sítio anatômico. 


\section{Expressão do gene MSLN}

Os valores médios de Ct e de expressão relativa do gene $M S L N$, bem como o $\log _{3}$ da expressão relativa, estão apresentados na Tabela 4 do Anexo 1.

Da mesma forma que para o gene KRT19, os resultados obtidos mostraram uma tendência para a redução de expressão de MSLN: 17 casos com expressão elevada e 26 com expressão reduzida, além de duas amostras de tumores (CP1/0056 T e CP3/0199 T) e três de margens (CP1/0255 M, CP1/0370 M e CP3/0019 M) sem presença aparente de transcritos (Figura 12). Essa tendência foi principalmente decorrente dos achados em carcinomas de laringe, que mostraram aumento de expressão em 2 amostras e redução em 5 no grupo NO e 2 casos com aumento e 7 com redução significativa de expressão no grupo $\mathrm{N}+$ (Figura 12 e Tabela 4 do Anexo 1).

Nos carcinomas de língua, 2 amostras revelaram aumento de transcrição do gene $M S L N$, sendo elas de pacientes sem metástases para linfonodos. Foram observadas 3 amostras com diminuição de expressão, sendo 1 No e 2 N+ (Figura 12 e Tabela 4 do Anexo 1).

As amostras de assoalho de boca, ao contrário do que foi encontrado em laringe, exibiram perfil homogêneo, com níveis elevados em 6 amostras NO e $4 \mathrm{~N}+$, e níveis reduzidos em 5 amostras No e $4 \mathrm{~N}+$ (Figura 12 e Tabela 4 do Anexo 1). Sem levar em conta a agressividade do tumor, 10 amostras apresentaram aumento de expressão e 9 com redução dos níveis de mRNA da mesotelina (Figura 12).

Observando a análise dos componentes principais, não houve associação entre os parâmetros analisado e a expressão diferencial da mesotelina. O teste $\mathrm{t}$ de Student não identificou diferença significativa entre os valores de expressão dos tumores $\mathrm{NO}$ e $\mathrm{N}+\mathrm{de}$ cada sítio anatômico. 
A

MSLN

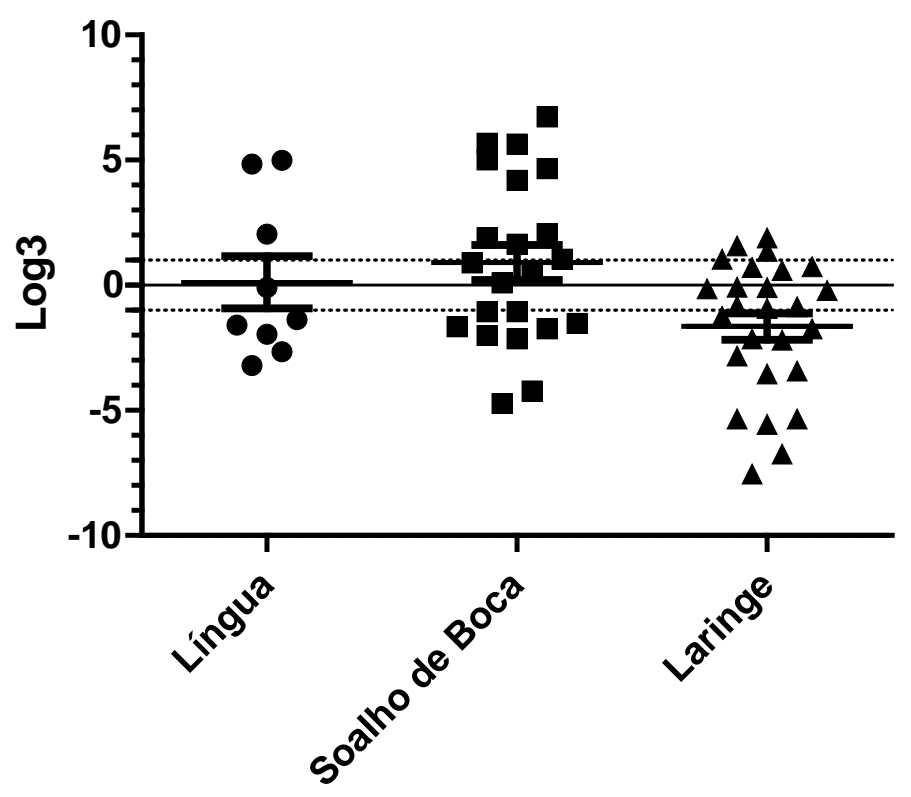

B

MSLN

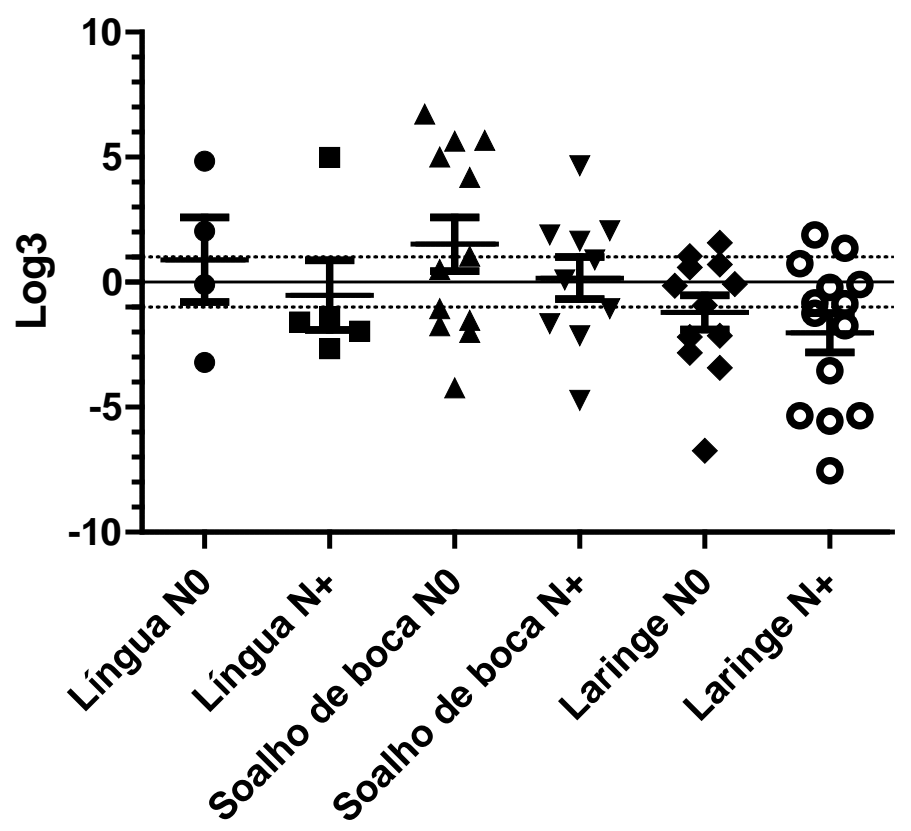

Figura 12. Valores de expressão relativa apresentados em $\log _{3}$, referentes à análise do gene $M S L N$ em amostras (A) de língua, soalho de boca e laringe e (B) No e N+ de cada sítio anatômico. 


\section{Expressão do gene $K L K 8$}

Os valores médios de Ct e de expressão relativa do gene $K L K 8$, bem como o $\log _{3}$ da expressão relativa, estão apresentados na Tabela 5 do Anexo 1.

Em média, as amostras analisadas não exibiram alteração de expressão do gene KLK8 (Figura 13). Individualmente, 16 possuíam aumento e 14 diminuição de expressão; em uma amostra de margem cirúrgica (CP3/0096 M), não foram detectados transcritos de $K L K 8$. As amostras de língua, entretanto, mostraram tendência à redução de níveis dos transcritos: 5 amostras tiveram redução (1 N0 e $4 \mathrm{~N}+$ ) e apenas 1 (N0) teve aumento de expressão (Figura 13 e Tabela 5 do Anexo 1).

Entre os carcinomas de soalho de boca, 9 apresentaram elevação de transcrição do gene KLK8, sendo 5 amostras N0 e $4 \mathrm{~N}+$, enquanto 3 amostras exibiram diminuição de expressão, todas $\mathrm{N}+$ (Figura 13 e Tabela 5 do Anexo 1). Nesse grupo verifica-se uma tendência de elevação da expressão da calicreína 8.

Nas amostras de laringe, 3 amostras NO e 3 N+ exibiram aumento de expressão, e 4 No e $2 \mathrm{~N}+$ exibiram redução de expressão (Figura 13 e Tabela 5 do Anexo 1).

Observando a análise dos componentes principais, não houve associação entre os parâmetros analisado e a expressão diferencial da calicreína 8. O teste $\mathrm{t}$ de Student não identificou diferença significativa entre os valores de expressão dos tumores $\mathrm{N} 0$ e $\mathrm{N}+\mathrm{de}$ cada sítio anatômico. 
A

KLK8

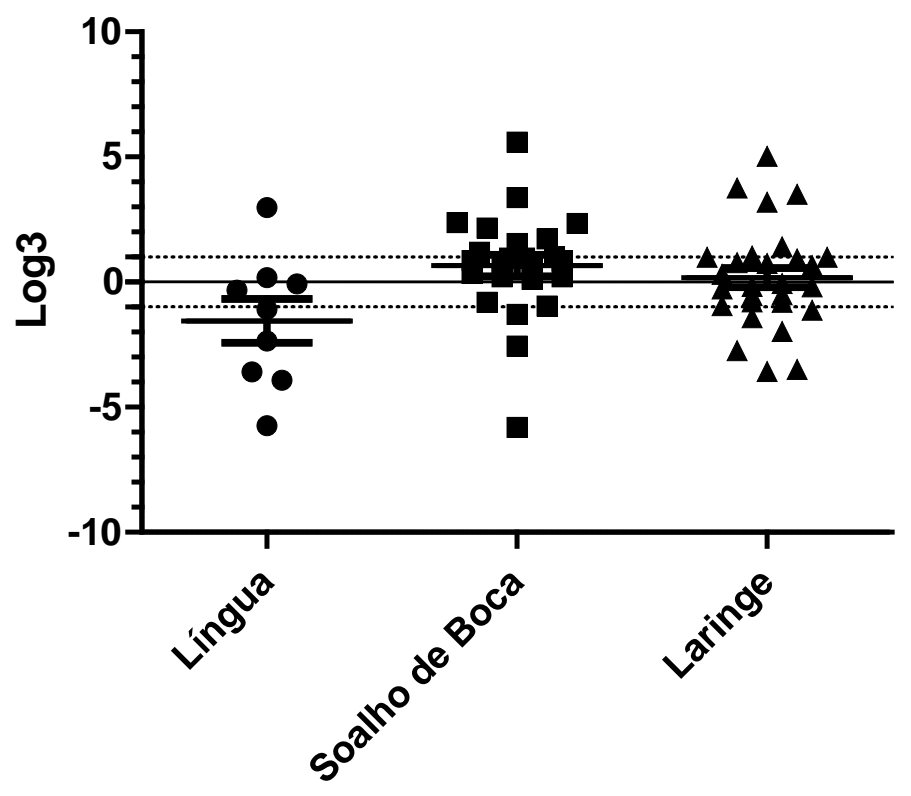

B

$K L K 8$

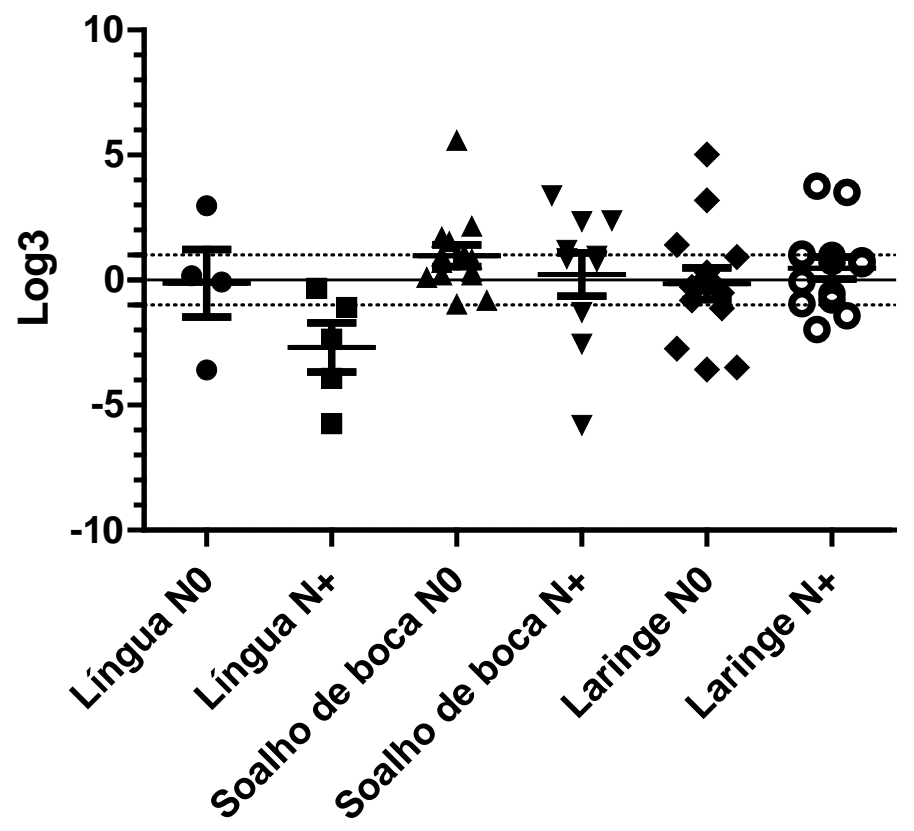

Figura 13. Valores de expressão relativa apresentados em $\log _{3}$, referentes à análise do gene $K L K 8$ em amostras $(\mathrm{A})$ de língua, soalho de boca e laringe e (B) No e N+ de cada sítio anatômico. 


\section{DISCUSSÃO}

O presente trabalho foi proposto com o objetivo de investigar o envolvimento de queratinas, mesotelina e calicreína na tumorigênese de cabeça e pescoço, com foco na busca de diferenças de expressão desses genes entre tumores metastáticos e não metastáticos. As amostras estudadas compreenderam linhagens celulares e amostras de queratinócitos bucais e de carcinomas epidermóides primários de cabeça e pescoço.

Verificando os dados das amostras de carcinomas, é observado que 88,9\% dos pacientes são do sexo masculino. Esse achado é comum nesse grupo de doenças e tem sido confirmado por muitos estudos (Argiris et al., 2008) e nas estatísticas disponíveis envolvendo um grande número de casos, como a Global Cancer Statistics (Parkin et al., 2002) e a SEER Cancer Statistics (Altekruse et al., 2009), ambas com predominância da incidência de CECP em homens, especialmente em portadores de carcinomas de laringe. Uma possível explicação para esse achado é o maior consumo de álcool e tabaco por indivíduos do sexo masculino e a maior resistência para busca de serviços médicos entre eles.

Entre os pacientes, 95,2\% dos casos estudados referiram consumo de tabaco e $88,8 \%$ tanto de tabaco como de álcool. Esses valores reforçam o fato bem conhecido de que o estilo de vida é de extrema importância para o risco de CECP. Diversos estudos da literatura já relataram o uso de tabaco e álcool como fator etiológico da doença e descreveram seu efeito multiplicativo quando ocorre a associação de ambos, que é estimada em $75 \%$ de todos os casos (Vineis et al., 2004; Blot et al., 1988; Argiris et al., 2008).

Outro fator associado ao câncer é a idade. Um aumento de mutações somáticas ocorre com o envelhecimento, resultado da exposição cumulativa a agentes endógenos e exógenos que lesam o DNA. Argiris e colaboradores (2008) citam que a idade média no momento do diagnóstico de CECP é em torno de 60 anos, muito próxima da idade média verificada neste estudo (56,6 anos). Entre as amostras utilizadas, apenas duas foram procedentes de pacientes com idades inferiores a 40 anos. Um fato interessante é que ambos nunca tinham consumido tabaco ou álcool e seus tumores ao diagnóstico foram classificados no estádio IV. Lajer e von Buchwald (2010) relatam que pacientes com CECP associados à infecção por HPV tendem a ser mais jovens, sem histórico de consumo de tabaco e álcool, frequentemente com tumores em estádios mais elevados, grandes linfonodos metastáticos, mas melhor prognóstico. Essa associação entre HPV e CECP explica a incidência desses tumores em pessoas mais jovens, sendo o vírus transmitido principalmente por práticas sexuais, o que infere importantes implicações em prevenção, diagnóstico e tratamento nesses casos. 
O número de casos com tumores metastáticos selecionados para estudos de validação foi aproximadamente o mesmo de não metastáticos (30 e 33, respectivamente). Esse total foi conseqüência da seleção realizada com o objetivo de uma representação equitativa dos dois grupos, que exibem características clínicas e prognósticos distintos. Entre essas diferenças, a presença de metástases em linfonodos regionais permanece como um dos mais importantes fatores prognósticos e representa um achado crítico para o delineamento do tratamento dos pacientes com carcinomas de cabeça e pescoço (Pantel e Brakenhoff, 2004). Tal tratamento inclui esvaziamento cervical nos casos $\mathrm{N}+$ que, dependendo de seu alcance, possui implicações sobre a qualidade de vida e sobre a morbimortalidade, geralmente elevada nesse grupo (Steeg e Theodorescu, 2008).

As amostras de tecido tumoral e margem cirúrgica utilizadas apresentaram boa qualidade de RNA, que é dependente de um procedimento adequado de coleta e armazenamento de amostras e fundamental para análises de expressão gênica. O presente estudo utilizou material obtido com protocolo otimizado pelo consórcio colaborativo GENCAPO (Genoma do Câncer de Cabeça e Pescoço) do projeto temático FAPESP "Busca de marcadores de agressividade em tumores de cabeça e pescoço". Nesse projeto, o tempo entre a retirada do espécime cirúrgico e seu armazenamento inicial em nitrogênio líquido foi padronizado em, no máximo, 30 minutos. Embora o procedimento cirúrgico envolva etapas não controláveis nas quais a peça perde oxigenação por causa do pinçamento de artérias durante sua retirada, a maioria das amostras desse projeto exibe boa qualidade. Além desse cuidado com o processamento e o armazenamento do material, cada caso esteve ligado a um grande número de informações clínicas, anatomopatológicas e de seguimento, que são de grande importância para análises de correlação com os achados de expressão gênica.

Para as etapas de validação dos genes de interesse, além das amostras de tumores primários, foram também utilizadas quatro linhagens celulares, todas procedentes de pacientes com carcinomas de cabeça e pescoço. Para controle normal no caso das linhagens, foram desenvolvidas culturas primárias de queratinócitos bucais humanos obtidos de indivíduos saudáveis, cultivados sobre camada de sustentação de fibroblastos murinos mitoticamente inativados por raio-X.

Os resultados obtidos a partir das curvas de crescimento dos fibroblastos murinos irradiados mostraram que a proliferação das células foi inibida de forma eficaz em ambas as doses utilizadas (60 e $80 \mathrm{~Gy}$ ) e mantiveram-se em cultura por período relativamente longo, confirmando sua potencialidade de utilização como camada de sustentação para a cultura de queratinócitos. Foi escolhida a dose de 60 Gy para a confecção da camada porque as células mantiveram-se mais tempo em cultura. O declínio do número de células irradiadas com a dose de 80 Gy foi maior, conforme evidenciado nos experimentos. 
A utilização da camada de sustentação possibilitou a propagação dos queratinócitos em culturas e contribuiu positivamente para sua adesão e proliferação. A camada de sustentação, além de fornecer suporte físico permitindo o desenvolvimento dos queratinócitos formadores de colônias ou clonogênicos, é capaz de sintetizar substâncias essências para o desenvolvimento de células epiteliais. Dessa maneira, é possível prolongar a cultura dos queratinócitos sem que ocorram etapas de diferenciação celular ou diminuição de potencial proliferativo.

Os queratinócitos orais derivados de indivíduos saudáveis, quando em cultura, apresentam características de normalidade, incluindo tempo finito de vida. Sua longevidade em cultura é variável, com relatos de 4 a 10 passagens em um período de até três meses (Freshney e Freshney, 2002). Para expansão, as células raramente são cultivadas além da terceira ou quarta passagem, porque o número de novas células equipara aquele das células que morrem. A eficiência clonal diminui de 40 a 90\% entre as passagens 1 e 3. Com o meio de cultura adequadamente enriquecido, os queratinócitos crescem em colônias macroscópicas contendo milhares de células, que podem ser usadas em experimentos ou subcultivadas por pelo menos 80 duplicações da população no caso de células de adultos (Freshney e Freshney, 2002) e mais de 140 duplicações se os doadores de tecido forem recém-nascidos (Rheinwald e Green, 1977).

No presente estudo, diversos hormônios e outros fatores solúveis foram adicionados ao meio de cultura de queratinócitos, entre eles hidrocortisona, toxina colérica, fator de crescimento epidérmico, insulina, triiodotironina e adenina. A hidrocortisona é essencial para manter a taxa de crescimento, a morfologia da colônia e a diferenciação de queratinócitos (Rheinwald e Green, 1975), e também previnem a deterioração da camada de sustentação (Pera e Gorman, 1984). A toxina colérica contrapõe a tendência dos queratinócitos de aumentarem o tamanho celular, por meio da elevação dos níveis de AMP cíclico (Green, 1978), possivelmente retardando sua diferenciação terminal (Sun e Green, 1976; Barrandon e Green, 1985). O fator de crescimento epidérmico (EGF) antagoniza a aglomeração das células no centro das colônias de queratinócitos (Rheinwald e Green, 1977), estimulando a duplicação e a migração celular para fora desse centro, consequentemente aumentando a longevidade e a quantidade de células na colônia (Barrandon e Green, 1987). O EGF parece também antagonizar a diferenciação terminal e aumentar o tamanho das populações em divisão e clonogênicas por um mecanismo distinto da toxina colérica (Rheinwald e Green, 1977; Green, 1978), sendo que o efeito desses dois agentes juntos é superior ao de cada um isoladamente (Green, 1978). Com a associação de hidrocortisona, toxina colérica e EGF, ocorre um aumento na fração clonogênica, na taxa de crescimento e no tempo de vida das células (Rheinwald, 1980; Green, 1980), possibilitando um grande número de queratinócitos humanos normais a partir de uma pequena amostra de tecido. A insulina e a 
triiodotironina (T3) reduzem a necessidade de soro fetal bovino de $20 \%$ para $10 \%$ e, mesmo na presença de soro com qualidade não ideal, aumentam a taxa de crescimento (Freshney e Freshney, 2002). A adenina inibe a proliferação de fibroblastos contaminantes e, consequentemente, a presença indesejada dessas células na cultura de queratinócitos (Breidahl et al., 1989).

Os queratinócitos cultivados foram utilizados como referência para as análises de expressão gênica em linhagens celulares procedentes de carcinomas de cabeça e pescoço, da mesma forma que os dados de margens cirúrgicas serviram de comparação para aqueles obtidos de tumores primários.

Para as análises de expressão gênica, foram selecionados genes identificados em um trabalho anterior do grupo, que desenvolveu uma abordagem estatística para análise de dados de bibliotecas SAGE de carcinomas de laringe metastáticos e não metastáticos e de uma biblioteca de tecido normal (Silveira et al., 2008). A partir de um total de mais de 50 mil tags diferencialmente expressas, foi criada uma lista contendo os genes com valores mais discriminativos na comparação de tumores $\mathrm{N}+$ e NO e margens cirúrgicas (Anexo 2). Aqueles com envolvimento potencial no processo ou no fenótipo neoplásico ou com um papel ainda não esclarecido na tumorigênese de cabeça e pescoço foram selecionados. Desses, quatro genes cujas funções estavam relacionadas com diferenciação/estrutura da epiderme e adesão celular seguiram para análises de validação: citoqueratina 6A (KRT6A), citoqueratina 19 (KRT19), mesotelina (MSLN) e calicreína 8 (KLK8). Como os dados de SAGE foram gerados a partir de carcinomas de laringe, os ensaios de validação foram realizados em amostras de tumores de laringe e também em dois grupos externos de outros sítios, língua e soalho de boca, e em linhagens de carcinomas de diferentes sítios.

Segundo os dados obtidos por Silveira e colaboradores (2008), ocorreu um aumento significativo de expressão do gene KRT6A em tumores de laringe N0 em relação aos N+. Para KRT19, esses autores observaram uma situação inversa, com aumento em $\mathrm{N}+$ em relação a No, porém com aumento muito maior em normal versus NO.

No presente estudo, os transcritos de KRT6A não foram expressos nas células Hep-2, uma linhagem celular originalmente descrita como sendo de carcinoma de laringe, e exibiram baixos níveis nas demais linhagens. Também não foram observadas as diferenças esperadas entre tumores de laringe $\mathrm{N}+$ e N0, ou para os demais tipos de tumores, exceto uma redução significativa de transcritos em tumores de língua metastáticos, um grupo com poucas amostras. A explicação para os achados deve estar no fato das bibliotecas SAGE terem sido geradas a partir de apenas uma amostra $\mathrm{N}+$ e uma N0, não representando o que ocorre na maioria dos casos.

$\mathrm{Na}$ comparação do total de amostras de tumores com as amostras de margens cirúrgicas, foi observada elevação e diminuição de expressão de KRT6A em 33\% e 21\% dos 
casos, respectivamente, portanto com uma pequena tendência para o grupo exibindo altos níveis.

Para o gene KRT19, as linhagens mostraram redução de níveis, exceto as células de tonsila que não exibiram diferença em relação aos queratinócitos normais. O mesmo foi observado nos tumores primários, principalmente para os de laringe, soalho de boca $\mathrm{N}+\mathrm{e}$ língua $\mathrm{N}+$, que exibiram redução significativa de expressão em relação às margens cirúrgicas, embora sem diferenças entre casos metastáticos e não metastáticos.

A relação das queratinas com o processo neoplásico pode ser avaliada pela análise de queratinopatias e camundongos knockout, que mostram o impacto dessas proteínas em arquitetura, tamanho e proliferação celular. Seu perfil de fosforilação e a identificação de proteínas associadas também fornecem dados para compreensão dos mecanismos moleculares pelos quais elas atuam (Magin et al., 2007). Por exemplo, os dados da literatura têm referido a conexão dos filamentos de queratina com as adesões focais em lamelipódios e com os sistemas de actina e microtúbulos, sugerindo sua importância na adaptação da célula a mudanças estruturais durante o desenvolvimento, a migração e a formação de metástases (Wöll et al., 2005; Windoffer et al., 2006). Em relação à fosforilação dos polipeptídeos de queratina, seu perfil afeta o status de polimerização (Omary et al., 1998) e também a susceptibilidade a situações adversas e apoptose. Essas características levaram Ku e Omary (2006) a sugerir que as queratinas, durante o estresse, agem como "esponja para fosfato", absorvendo o efeito da quinases ativadas e protegendo a célula de lesões.

Consequências funcionais de alterações transitórias na composição de queratinas também são importantes. Como referido previamente, o desequilíbrio nas proporções de heterodímeros de queratinas, no caso $\mathrm{K} 6 / \mathrm{K} 16$, altera o potencial migratório dos queratinócitos, o que pode ter importantes implicações na sua capacidade migratória (Trost et al., 2010) e em metástases. Seria, portanto, esperado que uma alteração de expressão de KRT6A fosse observado em tumores, especialmente nos mais agressivos. Os resultados obtidos no presente trabalho, embora negativos para essa relação, podem ser conseqüência da presença ou ausência de outras queratinas, ou de sua fosforilação, alternativas que merecem ser melhor investigadas.

Em relação à KRT19, ao contrário dos dados deste estudo, alguns trabalhos mostraram aumento de expressão de transcritos e/ou de seu produto em carcinomas orais e sua correlação com baixo grau de diferenciação (Ram Prassad et al., 2005), recorrência e baixa sobrevida (Zhong et al., 2007). Tao e colaboradores (2006) também observaram níveis elevados de transcritos da citoqueratina 19 em linfonodos de pacientes com carcinomas epidermóides de cabeça e pescoço. No conjunto de 31 pacientes analisados, 
apenas um era portador de lesão de laringe e sete de cavidade oral, o que pode ser responsável pelas diferenças com os resultados do presente estudo, que incluiu 29 casos de laringe e 34 de cavidade oral. De qualquer modo, o estudo de Tao e colaboradores demonstrou a sensibilidade da técnica de PCR em tempo real para detecção de células epiteliais, potencialmente micrometástases, em linfonodos.

Em outros tumores epiteliais, como os carcinomas epidermóides cutâneos, a queratina 19 mostra expressão elevada. Esse resultado parece estar associado com características de célula tronco ou a um estado de descomprometimento com a diferenciação terminal (Chen et al., 2008), um achado que também já foi observado em lesões pré-malignas orais (Lindberg e Rheinwald, 1989).

Outro gene cuja expressão foi avaliada neste trabalho foi o MSLN. De acordo com Silveira e colaboradores (2008), ocorre um aumento de expressão da mesotelina nos tumores de laringe $\mathrm{N}+$ em relação aos NO e aos tecidos normais. Os dados obtidos no presente estudo mostraram um perfil variável em linhagens celulares, com níveis elevados em células de laringe e orofaringe. Em tumores primários, foi observada uma redução de expressão significativa nos tumores de laringe e uma tendência para aumento nos de soalho de boca. Com estratificação quanto ao sítio e à presença de metástases, o aumento se manteve nos casos de soalho de boca NO do mesmo modo que a redução nos casos de laringe.

O aumento de expressão da mesotelina já foi observado em diversos tumores, como câncer pancreático, de ovário e mesotelioma (Chang e Pastan, 1996), bem como em câncer de cabeça e pescoço, vulva, endométrio, pulmão, fígado e esôfago (Chang et al., 1992; Ordonez, 2003; Miettinen e Sarlomo-Rikala, 2003). Uma forte imunorreatividade para a mesotelina em tecidos normais está restrita às células mesoteliais que limitam a pleura, o pericárdio e o peritônio.

Segundo os dados de ESTs do UniGene, não há expressão de mesotelina em tecidos normais de laringe e boca (http://www.ncbi.nlm.nih.gov/unigene?log $\$=$ breadcrumbs). Contudo, nas amostras de margens cirúrgicas analisadas, apenas 3 não exibiram transcritos do gene MSLN. Uma possibilidade é que, apesar da avaliação de todas as amostras por um patologista e da aparente morfologia normal, as margens podem conter alterações genéticas e/ou epigenéticas. Essa possibilidade é explicada pelo conceito de cancerização de campo de Slaughter et al. (1953), que propõe a transformação neoplásica em múltiplos grupos celulares de um mesmo tecido, sob o estresse da atividade regional de um carcinógeno. Segundo esses autores existe um tecido "pré-canceroso" ao redor do tumor primário cuja persistência após ressecção cirúrgica pode explicar o aumento de taxas de recorrência nos pacientes. Realmente, quando um CECP primário é comparado com um segundo tumor em 
outro sítio do trato aerodigestivo superior, padrões idênticos de danos genéticos são detectados (Bedi et al., 1996; Worsham et al., 1995; Scholes et al., 1998; Leong et al., 1998). Provavelmente, em algum momento após a sua transformação, as células que adquiriram alterações em seu DNA migram para preencher espaços adjacentes de mucosa, acumulando outras mutações, adquirindo vantagens adicionais de crescimento e, finalmente, transformando-se em subclones agressivos separados pelo tempo e espaço (Califano et al., 2000).

No momento, os resultados da análise histopatológica convencional de seções congeladas de tecido são utilizados para guiar os clínicos no tratamento e na estimativa de desfechos para o paciente com CECP. Entretanto, a natureza subjetiva dessa análise e a alta taxa de recorrência observada colocam limitações para os resultados. No futuro, quando alterações moleculares específicas e suas contribuições para o fenótipo tumoral forem identificadas, sua detecção poderá ser empregada para avaliar as margens cirúrgicas e o comportamento da lesão (Kim e Califano, 2004). Levando em conta os pontos levantados acima, a margem cirúrgica poderia apresentar expressão elevada de MSLN e interferir nas análises comparativas com as amostras tumorais.

A função biológica da mesotelina ainda não é clara, mas existem indícios de sua participação em processos ligados a proliferação celular, diferenciação, apoptose (Prieve e Moon, 2003; Bharadwaj et al., 2008), adesão (Rump et al., 2004), resistência à quimioterapia (Cheng et al., 2009) e metástase (Gubbels et al., 2006; Uehara et al., 2008)

O quarto gene selecionado para ensaios de validação foi o $K L K 8$. No trabalho de Silveira e colaboradores (2008), esse gene mostrou expressão reduzida em tumor de laringe metastático em relação ao não metastático. Entre as amostras analisadas, a maioria das linhagens celulares mostrou redução significativa de expressão de $K L K 8$, o que também foi observado nas amostras de língua N+, ao contrário de soalho de boca NO.

A calicreína 8 já foi observada com níveis elevados em células e fluidos de diferentes neoplasias (Underwood et al., 1999; Gan et al., 2000; Kishi et al., 2003; Cané et al., 2004; Yousef et al., 2004) e níveis reduzidos em outras (Yousef et al., 2004). Em carcinomas de cabeça e pescoço, os dados são também controversos, com diminuição de expressão em metástases linfonodais (Liu et al., 2008) ou aumento nas amostras tumorais (Pettus et al., 2009).

Embora as enzimas proteolíticas participem geralmente da progressão neoplásica, degradando a matriz extracelular, tem sido observada expressão elevada de calicreína 8 em linhagens celulares de baixa invasividade e associada com bom prognóstico em câncer de pulmão de células não-pequenas (Sher et al., 2006) e em câncer de ovário (Shigemasa et al., 2004; Borgoño et al., 2006). Vários trabalhos referem o efeito dessa protease na adesão 
e migração (Tani et al., 2001), na degradação de algumas proteínas da matriz (Rajapakse et al., 2005) e na ativação de metaloproteases (Ohler et al., 2010).

Sher e colaboradores (2006) sugerem que esse efeito é decorrente da degradação da fibronectina da matriz pela calicreína 8. Os fragmentos dessa clivagem são potentes inibidores de proliferação de células endoteliais, exercendo portanto um efeito antiangiogênico. Além disso, a fibronectina interage com integrinas e, dependendo do tipo de complexo formado, os efeitos sobre migração/invasão podem ser opostos.

Os resultados do presente trabalho em CECPs de língua e soalho de boca também estão de acordo com a idéia de que níveis mais altos de KLK8 em N0 podem indicar melhor prognóstico, considerando que a ausência de metástases em linfonodos regionais é um dos mais importantes fatores para um desfecho favorável (Pantel e Brakenhoff, 2004).

Em resumo, os ensaios de validação em CECP por RT-PCR em tempo real dos genes KRT6A, KRT19, MSLN e KLK8, previamente observados com expressão alterada em análise de bibliotecas SAGE de tumores metastáticos e não metastáticos de laringe, mostraram resultados compatíveis com o esperado em alguns casos, mas revelaram também um perfil diferente daquele descrito na literatura em outros tumores. Considerando a função dos genes de interesse, esses achados merecem ser melhor investigados.

As abordagens utilizadas para identificar eventos metabólicos essenciais em câncer incluem a manipulação da expressão de genes de interesse em linhagens celulares e a determinação de seus efeitos em proliferação, migração, invasividade e em outros processos. Entretanto, o sucesso dessas abordagens depende da seleção de alguns genes promissores a partir de um grande número de candidatos, identificados por técnicas de larga escala. Uma análise alternativa é a identificação de genes que possuem expressão alterada em tecido tumoral versus tecido normal correspondente (Chen et al., 2004). O grande problema é selecionar os parâmetros que definem a amostra normal.

Os tecidos aparentemente normais de margens cirúrgicas são retirados a uma distância de alguns centímetros do tumor e podem estar contaminados por células inflamatórias em diferentes níveis, como ocorre em carcinomas de cabeça e pescoço, ou por células com alterações genéticas ou definitivamente tumorais. Esse último evento não deve ser raro considerando as taxas de recorrência local de 50\% nesses pacientes, mesmo com margens cirúrgicas microscopicamente negativas (Nathan et al., 2002). Se esses tecidos forem utilizados para comparações de expressão gênica, o valor obtido em tumores pode estar sub ou superestimado. Portanto, é importante que a elaboração das conclusões do trabalho seja feita com grande cautela. 


\section{CONCLUSÕES}

As principais conclusões obtidas no presente trabalho estão relacionadas a seguir:

1. A proliferação de fibroblastos murinos é inibida com doses de 60 Gy de raios- $X, 0$ que permite sua utilização como camada alimentadora em culturas de queratinócitos.

2. Os queratinócitos bucais humanos normais crescem em camada de sustentação de fibroblastos irradiados e em meio de cultura enriquecido com hidrocortisona, toxina colérica, fator de crescimento epidérmico, insulina, triiodotironina e adenina.

3. Na comparação pareada de amostras de margens cirúrgicas com amostras de carcinomas epidermóides primários de língua, soalho de boca e laringe procedentes de pacientes, na sua maioria, do sexo masculino, fumantes e etilistas e com idades superiores a 40 anos, ocorre (a) redução de expressão do gene KRT6A em tumores de língua metastáticos; (b) redução de expressão do gene KRT19 em tumores de laringe, independentemente do status linfonodal, bem como em tumores de soalho de boca e língua metastáticos; (c) redução de expressão do gene MSLN nos tumores de laringe, independentemente da presença de metástases regionais, e aumento nos tumores de soalho de boca não metastático; (d) redução de expressão do gene $K L K 8$ em tumores de língua $\mathrm{N}+\mathrm{e}$ aumento em tumores de soalho de boca NO.

4. Na comparação com queratinócitos de gengiva cultivados, as amostras de linhagens celulares procedentes de carcinomas epidermóides de cabeça e pescoço exibem (a) redução ou ausência de expressão do gene KRT6A; (b) redução de expressão do gene KRT19 na maioria das linhagens; (c) perfil variável de expressão para o gene $M S L N$; (d) redução de expressão do gene $K L K 8$ na maioria das linhagens.

5. A metodologia de SAGE é uma importante fonte de informações sobre o câncer, mas seus dados necessitam de validação por outras técnicas em maior número de casos.

6. Os dados obtidos no presente estudo e os dados da literatura sugerem o gene $K L K 8$ como potencial alvo para estudos funcionais posteriores. 


\section{RESUMO}

Os carcinomas de cabeça e pescoço (CECPs) compreendem um grupo de tumores que atingem vários sítios do trato aerodigestivo superior, incluindo cavidade oral, orofaringe, hipofaringe e laringe. Esses carcinomas são clinicamente heterogeneous e resultam de modificações cumulativas em genes que regulam proliferação, migração celular e apoptose. São estimados aproximadamente 500.000 novos casos de CECP anualmente no mundo. No Brasil, cerca de 14.000 novos casos são esperados em 2010, somente para cavidade oral. As taxas de morbidade e mortalidade e as limitações das estratégias terapêuticas enfatizam a necessidade de um melhor entendimento dos padrões moleculares envolvidos na iniciação e na progressão desses tumores, e de abordagens preventivas e terapêuticas efetivas. Infelizmente, apesar da intensa pesquisa nessa área, poucos marcadores moleculares são conhecidos que exibam sensibilidade e especificidade para diagnóstico e prognóstico de CECP. Em um estudo prévio, nós avaliamos dados de três bibliotecas SAGE de carcinoma de laringe com a finalidade de identificar eventos associados ao desenvolvimento e à agressividade de CECP. Utilizando abordagens estatísticas e de Bioinformática, nós identificamos 60 genes com expressão elevada ou reduzida em tumores metastáticos versus não-metastáticos e em ambos os grupos versus tecidos normais. O objetivo do presente estudo foi avaliar a expressão de quatro genes desta lista, os das queratinas $6 \mathrm{~A}$ (KRT6A) e 19 (KRT19), da mesotelina (MSLN) e da calicreína 8 (KLK8), em um conjunto de 63 carcinomas primários de cabeça e pescoço e suas margens cirúrgicas e em quarto linhagens celulares (Hep-2, FaDu, SCC9 e UM-SSC-38) por RT-PCR em tempo real. Como amostra de referência para as linhagens, foram utilizados queratinócitos orais humanos normais, cultivados sobre uma camada de sustentação de fibroblastos irradiados. Todos os genes exibiram níveis de transcritos reduzidos ou ausentes nas linhagens celulares, exceto $M S L N$, que mostrou um padrão irregular de expressão. Em tumores primários, os genes KRT19 e MSLN apresentaram expressão diminuída em laringe, o mesmo sendo observado para o gene $K L K 8$ em tumores de língua metastático. Além disso, foi detectada expressão elevada de MSLN e KLK8 em tumores não metastáticos de soalho de boca e expressão reduzida de KRT19 em tumores de soalho de boca e língua metastáticos. Os resultados levantam questões sobre o papel desses genes em processos biológicos associados com a tumorigênese de cabeça e pescoço e sobre sua participação no fenótipo neoplásico. 


\section{ABSTRACT}

Head and neck squamous cell carcinomas (HNSCCs) encompass a group of tumors that affect a variety of sites in the upper aero-digestive tract, including oral cavity, oropharynx, hypopharynx and larynx. These carcinomas are clinically heterogeneous and result from cumulative changes in genes that regulate cell proliferation, migration and death. It is estimated that approximately 500,000 new cases of HNSCC are diagnosed worldwide each year. In Brazil, about 14,000 new cases are expected in the year 2010, only in oral cavity. The morbidity and mortality rates and the limitations of therapeutic strategies emphasize the need for a better understanding of the molecular pathways involved in the initiation and progression of these tumors and for effective preventive and therapeutic approaches. Unfortunately, despite intense research, few molecular markers are known to exhibit sensitivity and specificity for the diagnosis or prognosis of HNSCC. In a previous study, we evaluated data from three SAGE libraries of larynx carcinoma in order to identify events associated with the development and aggressiveness of HNSCCs. Using statistical and bioinformatic tools, we identified sixty top-up and 60 topdownregulated genes in metastatic versus non-metastatic tumors and in both these tumors versus normal tissues. The objective of the present study was to evaluate the expression of four genes from this list, keratin 6A (KRT6A), keratin 19 (KRT19), mesothelin (MSLN) and kallikrein 8 (KLK8), in a set of 63 primary carcinomas of head and neck and their surgical margins and in four cell lines (Hep-2, FaDu, SCC9 and UM-SSC38) by real time RT-PCR. As a reference sample for cell lines, we used normal human oral keratinocytes grown on irradiated fibroblast feeder layer. All genes exhibited no or decreased levels of transcripts in the cell lines, except MSLN, which displayed an irregular pattern of expression. In primary tumors, KRT19 and MSLN genes were downregulated in larynx, and $K L K 8$ in metastatic tongue tumors. In addition, MSLN and $K L K 8$ were upregulated in non-metastatic floor of the mouth tumors and KRT19 was down regulated in metastatic floor of the mouth and tongue tumors. The results open questions about the role of these genes on biological processes related to head and neck tumorigenesis and on neoplastic phenotype. 


\section{REFERÊNCIAS BIBLIOGRÁFICAS}

Aldington, S., M. Harwood, et al. Cannabis use and cancer of the head and neck: casecontrol study. Otolaryngol Head Neck Surg, v.138, n.3, Mar, p.374-80. 2008.

Altekruse Sf, K. C., Krapcho M, Neyman N, Aminou R, Waldron W, Ruhl J, Howlader N, Tatalovich Z, Cho H, Mariotto a, Eisner Mp, Lewis Dr, Cronin K, Chen Hs, Feuer Ej, Stinchcomb Dg, Edwards Bk. SEER Cancer Statistics Review, 1975-2007. 2010.

Andreasen, P. A., R. Egelund, et al. The plasminogen activation system in tumor growth, invasion, and metastasis. Cell Mol Life Sci, v.57, n.1, Jan 20, p.25-40. 2000.

Argiris, A., M. V. Karamouzis, et al. Head and neck cancer. Lancet, v.371, n.9625, May 17, p.1695-709. 2008.

Balbo, S., M. Hashibe, et al. N2-ethyldeoxyguanosine as a potential biomarker for assessing effects of alcohol consumption on DNA. Cancer Epidemiol Biomarkers Prev, v.17, n.11, Nov, p.3026-32. 2008.

Balz, V., K. Scheckenbach, et al. Is the p53 inactivation frequency in squamous cell carcinomas of the head and neck underestimated? Analysis of p53 exons 2-11 and human papillomavirus 16/18 E6 transcripts in 123 unselected tumor specimens. Cancer Res, v.63, n.6, Mar 15, p.1188-91. 2003.

Bambang, I. F., D. Lu, et al. Cytokeratin 19 regulates endoplasmic reticulum stress and inhibits ERp29 expression via p38 MAPK/XBP-1 signaling in breast cancer cells. Exp Cell Res, v.315, n.11, Jul 1, p.1964-74. 2009.

Barak, V., H. Goike, et al. Clinical utility of cytokeratins as tumor markers. $\underline{\text { Clin Biochem, }}$ v.37, n.7, Jul, p.529-40. 2004.

Barrandon, Y. e H. Green. Cell size as a determinant of the clone-forming ability of human keratinocytes. Proc Natl Acad Sci U S A, v.82, n.16, Aug, p.5390-4. 1985.

Barrandon, Y. e H. Green. Cell migration is essential for sustained growth of keratinocyte colonies: the roles of transforming growth factor-alpha and epidermal growth factor. Cell, v.50, n.7, Sep 25, p.1131-7. 1987.

Becker-Pauly, C., M. Howel, et al. The alpha and beta subunits of the metalloprotease meprin are expressed in separate layers of human epidermis, revealing different functions in keratinocyte proliferation and differentiation. J Invest Dermatol, v.127, n.5, May, p.1115-25. 2007.

Bedi, G. C., W. H. Westra, et al. Multiple head and neck tumors: evidence for a common clonal origin. Cancer Res, v.56, n.11, Jun 1, p.2484-7. 1996.

Bera, T. K. e I. Pastan. Mesothelin is not required for normal mouse development or reproduction. Mol Cell Biol, v.20, n.8, Apr, p.2902-6. 2000.

Bergkvist, A., V. Rusnakova, et al. Gene expression profiling--Clusters of possibilities. Methods, v.50, n.4, Apr, p.323-35.

Berthiller, J., Y. C. Lee, et al. Marijuana smoking and the risk of head and neck cancer: pooled analysis in the INHANCE consortium. Cancer Epidemiol Biomarkers Prev, v.18, n.5, 
May, p.1544-51. 2009.

Bharadwaj, U., M. Li, et al. Mesothelin-induced pancreatic cancer cell proliferation involves alteration of cyclin $\mathrm{E}$ via activation of signal transducer and activator of transcription protein 3. Mol Cancer Res, v.6, n.11, Nov, p.1755-65. 2008.

Blot, W. J., J. K. Mclaughlin, et al. Smoking and drinking in relation to oral and pharyngeal cancer. Cancer Res, v.48, n.11, Jun 1, p.3282-7. 1988.

Boeing, H., T. Dietrich, et al. Intake of fruits and vegetables and risk of cancer of the upper aero-digestive tract: the prospective EPIC-study. Cancer Causes Control, v.17, n.7, Sep, p.957-69. 2006.

Borgoño, C. A. e E. P. Diamandis. The emerging roles of human tissue kallikreins in cancer. Nat Rev Cancer, v.4, n.11, Nov, p.876-90. 2004.

Borgoño, C. A., T. Kishi, et al. Human kallikrein 8 protein is a favorable prognostic marker in

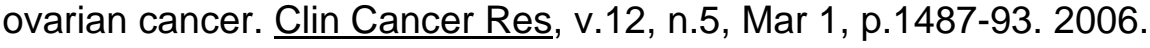

Borgoño, C. A., I. P. Michael, et al. Human tissue kallikreins: physiologic roles and applications in cancer. Mol Cancer Res, v.2, n.5, May, p.257-80. 2004.

Bosetti, C., S. Gallus, et al. Tobacco smoking, smoking cessation, and cumulative risk of upper aerodigestive tract cancers. Am J Epidemiol, v.167, n.4, Feb 15, p.468-73. 2008.

Bragulla, H. H. e D. G. Homberger. Structure and functions of keratin proteins in simple, stratified, keratinized and cornified epithelia. J Anat, v.214, n.4, Apr, p.516-59. 2009.

Breidahl, A. F., R. T. Judson, et al. Review of keratinocyte culture techniques: problems of growing skin. Aust N Z J Surg, v.59, n.6, Jun, p.485-97. 1989.

Brembeck, F. H. e A. K. Rustgi. The tissue-dependent keratin 19 gene transcription is regulated by GKLF/KLF4 and Sp1. J Biol Chem, v.275, n.36, Sep 8, p.28230-9. 2000.

Brennan, J. A., J. O. Boyle, et al. Association between cigarette smoking and mutation of the p53 gene in squamous-cell carcinoma of the head and neck. N Engl J Med, v.332, n.11, Mar 16, p.712-7. 1995.

Califano, J., P. Van Der Riet, et al. Genetic progression model for head and neck cancer: implications for field cancerization. Cancer Res, v.56, n.11, Jun 1, p.2488-92. 1996.

Califano, J., W. H. Westra, et al. Genetic progression and clonal relationship of recurrent

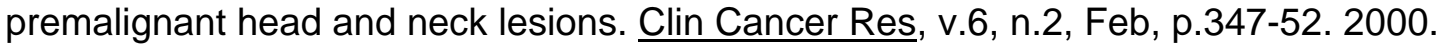

Calmon, M. F., R. V. Rodrigues, et al. Epigenetic silencing of CRABP2 and MX1 in head and neck tumors. Neoplasia, v.11, n.12, Dec, p.1329-39. 2009.

Cancela, M. C., L. Voti, et al. Oral cavity cancer in developed and in developing countries: population-based incidence. Head Neck, v.32, n.3, Mar, p.357-67.

Cané, S., E. Bignotti, et al. The novel serine protease tumor-associated differentially expressed gene-14 (KLK8/Neuropsin/Ovasin) is highly overexpressed in cervical cancer. Am J Obstet Gynecol, v.190, n.1, Jan, p.60-6. 2004. 
Capaccio, P., G. Pruneri, et al. Cyclin D1 expression is predictive of occult metastases in head and neck cancer patients with clinically negative cervical lymph nodes. Head Neck, v.22, n.3, May, p.234-40. 2000.

Chang, K. e I. Pastan. Molecular cloning of mesothelin, a differentiation antigen present on mesothelium, mesotheliomas, and ovarian cancers. Proc Natl Acad Sci U S A, v.93, n.1, Jan 9, p.136-40. 1996.

Chang, K., I. Pastan, et al. Isolation and characterization of a monoclonal antibody, K1, reactive with ovarian cancers and normal mesothelium. Int J Cancer, v.50, n.3, Feb 1, p.37381. 1992.

Chang, S. S., W. W. Jiang, et al. MicroRNA alterations in head and neck squamous cell carcinoma. Int J Cancer, v.123, n.12, Dec 15, p.2791-7. 2008.

Chen, L. C., C. Y. Hao, et al. Alteration of gene expression in normal-appearing colon mucosa of APC(min) mice and human cancer patients. Cancer Res, v.64, n.10, May 15, p.3694-700. 2004.

Chen, S., M. Takahara, et al. Increased expression of an epidermal stem cell marker, cytokeratin 19, in cutaneous squamous cell carcinoma. $\mathrm{Br} \mathrm{J}$ Dermatol, v.159, n.4, Sep, p.952-5. 2008.

Chen, T. F., G. L. Jiang, et al. CK19 mRNA expression measured by reverse-transcription polymerase chain reaction (RT-PCR) in the peripheral blood of patients with non-small cell lung cancer treated by chemo-radiation: an independent prognostic factor. Lung Cancer, v.56, n.1, Apr, p.105-14. 2007.

Cheng, W. F., C. Y. Huang, et al. High mesothelin correlates with chemoresistance and poor survival in epithelial ovarian carcinoma. Br J Cancer, v.100, n.7, Apr 7, p.1144-53. 2009.

Chow, L. T., T. R. Broker, et al. The natural history of human papillomavirus infections of the mucosal epithelia. APMIS, v.118, n.6-7, Jun, p.422-49.

Curado, M. P. e M. Hashibe. Recent changes in the epidemiology of head and neck cancer. Curr Opin Oncol, v.21, n.3, May, p.194-200. 2009.

Dasgupta, S., P. K. Tripathi, et al. Identification of molecular targets for immunotherapy of patients with head and neck squamous cell carcinoma. Oral Oncol, v.42, n.3, Mar, p.306-16. 2006.

D'souza, G., A. R. Kreimer, et al. Case-control study of human papillomavirus and oropharyngeal cancer. N Engl J Med, v.356, n.19, May 10, p.1944-56. 2007.

Ferlay J, B. F., Pisani P, Parkin Dm. Globocan 20022004.

Foulkes, W. D., J. S. Brunet, et al. Familial risks of squamous cell carcinoma of the head and neck: retrospective case-control study. BMJ, v.313, n.7059, Sep 21, p.716-21. 1996.

Freedman, N. D., Y. Park, et al. Fruit and vegetable intake and head and neck cancer risk in a large United States prospective cohort study. Int J Cancer, v.122, n.10, May 15, p.2330-6. 2008.

Freshney, R. I., Freshney, M. G. Culture of epithelial cells. New York: Wiley-Liss. 2002 
Gan, L., I. Lee, et al. Sequencing and expression analysis of the serine protease gene cluster located in chromosome 19q13 region. Gene, v.257, n.1, Oct 17, p.119-30. 2000.

Gilbert, R. W. Innovation in the surgical management of head and neck tumors. Hematol Oncol Clin North Am, v.22, n.6, Dec, p.1181-91, viii-ix. 2008.

Gollin, S. M. Chromosomal alterations in squamous cell carcinomas of the head and neck: window to the biology of disease. Head Neck, v.23, n.3, Mar, p.238-53. 2001.

Green, H. Cyclic AMP in relation to proliferation of the epidermal cell: a new view. Cell, v.15, n.3, Nov, p.801-11. 1978.

Green, H. The keratinocyte as differentiated cell type. Harvey Lect, v.74, p.101-39. 1980.

Gubbels, J. A., J. Belisle, et al. Mesothelin-MUC16 binding is a high affinity, N-glycan dependent interaction that facilitates peritoneal metastasis of ovarian tumors. Mol Cancer, v.5, n.1, p.50. 2006.

Guha, N., P. Boffetta, et al. Oral health and risk of squamous cell carcinoma of the head and neck and esophagus: results of two multicentric case-control studies. Am J Epidemiol, v.166, n.10, Nov 15, p.1159-73. 2007.

Ha, P. K., N. E. Benoit, et al. A transcriptional progression model for head and neck cancer. Clin Cancer Res, v.9, n.8, Aug 1, p.3058-64. 2003.

Ha, P. K., S. S. Chang, et al. Molecular techniques and genetic alterations in head and neck cancer. Oral Oncol, v.45, n.4-5, Apr-May, p.335-9. 2009.

Hamakawa, H., Y. Bao, et al. Cytokeratin expression in squamous cell carcinoma of the lung and oral cavity: an immunohistochemical study with possible clinical relevance. Oral Surg Oral Med Oral Pathol Oral Radiol Endod, v.85, n.4, Apr, p.438-43. 1998.

Hashibe, M., P. Boffetta, et al. Evidence for an important role of alcohol- and aldehydemetabolizing genes in cancers of the upper aerodigestive tract. Cancer Epidemiol Biomarkers Prev, v.15, n.4, Apr, p.696-703. 2006.

Hashibe, M., P. Brennan, et al. Interaction between tobacco and alcohol use and the risk of head and neck cancer: pooled analysis in the International Head and Neck Cancer Epidemiology Consortium. Cancer Epidemiol Biomarkers Prev, v.18, n.2, Feb, p.541-50. 2009.

Hashibe, M., H. Morgenstern, et al. Marijuana use and the risk of lung and upper aerodigestive tract cancers: results of a population-based case-control study. Cancer Epidemiol Biomarkers Prev, v.15, n.10, Oct, p.1829-34. 2006.

Hassan, R. e M. Ho. Mesothelin targeted cancer immunotherapy. Eur J Cancer, v.44, n.1, Jan, p.46-53. 2008.

Herrero, R., X. Castellsague, et al. Human papillomavirus and oral cancer: the International Agency for Research on Cancer multicenter study. J Natl Cancer Inst, v.95, n.23, Dec 3, p.1772-83. 2003.

Hickerson, R. P., D. Leake, et al. Rapamycin selectively inhibits expression of an inducible keratin (K6a) in human keratinocytes and improves symptoms in pachyonychia congenita patients. J Dermatol Sci, v.56, n.2, Nov, p.82-8. 2009. 
Hiraki, A., K. Matsuo, et al. Teeth loss and risk of cancer at 14 common sites in Japanese. Cancer Epidemiol Biomarkers Prev, v.17, n.5, May, p.1222-7. 2008.

Ho, M., R. Hassan, et al. Humoral immune response to mesothelin in mesothelioma and ovarian cancer patients. Clin Cancer Res, v.11, n.10, May 15, p.3814-20. 2005.

Hucl, T., J. R. Brody, et al. High cancer-specific expression of mesothelin (MSLN) is attributable to an upstream enhancer containing a transcription enhancer factor dependent MCAT motif. Cancer Res, v.67, n.19, Oct 1, p.9055-65. 2007.

Hunter, K. D., E. K. Parkinson, et al. Profiling early head and neck cancer. Nat Rev Cancer, v.5, n.2, Feb, p.127-35. 2005.

Ignatiadis, M., V. Georgoulias, et al. Micrometastatic disease in breast cancer: clinical implications. Eur J Cancer, v.44, n.18, Dec, p.2726-36. 2008.

Ignatiadis, M., M. Perraki, et al. Molecular detection and prognostic value of circulating cytokeratin-19 messenger RNA-positive and HER2 messenger RNA-positive cells in the peripheral blood of women with early-stage breast cancer. Clin Breast Cancer, v.7, n.11, Dec, p.883-9. 2007.

Ishida-Yamamoto, A., T. Senshu, et al. Sequential reorganization of cornified cell keratin filaments involving filaggrin-mediated compaction and keratin 1 deimination. $\underline{\mathrm{J}}$ Invest Dermatol, v.118, n.2, Feb, p.282-7. 2002.

Ishida-Yamamoto, A., H. Takahashi, et al. Lessons from disorders of epidermal differentiation-associated keratins. Histol Histopathol, v.17, n.1, Jan, p.331-8. 2002.

Karamouzis, M. V., J. R. Grandis, et al. Therapies directed against epidermal growth factor receptor in aerodigestive carcinomas. JAMA, v.298, n.1, Jul 4, p.70-82. 2007.

Kim, M. M. e J. A. Califano. Molecular pathology of head-and-neck cancer. Int J Cancer, v.112, n.4, Nov 20, p.545-53. 2004.

Kim, S., P. Wong, et al. A keratin cytoskeletal protein regulates protein synthesis and epithelial cell growth. Nature, v.441, n.7091, May 18, p.362-5. 2006.

Kirihara, T., K. Matsumoto-Miyai, et al. Prolonged recovery of ultraviolet B-irradiated skin in neuropsin (KLK8)-deficient mice. Br J Dermatol, v.149, n.4, Oct, p.700-6. 2003.

Kishi, T., L. Grass, et al. Human kallikrein 8, a novel biomarker for ovarian carcinoma. Cancer Res, v.63, n.11, Jun 1, p.2771-4. 2003.

Kishi, T., L. Grass, et al. Human kallikrein 8: immunoassay development and identification in tissue extracts and biological fluids. Clin Chem, v.49, n.1, Jan, p.87-96. 2003.

Kishibe, M., Y. Bando, et al. Kallikrein 8 is involved in skin desquamation in cooperation with other kallikreins. J Biol Chem, v.282, n.8, Feb 23, p.5834-41. 2007.

Klussmann, J. P., J. J. Mooren, et al. Genetic signatures of HPV-related and unrelated oropharyngeal carcinoma and their prognostic implications. Clin Cancer Res, v.15, n.5, Mar 1, p.1779-86. 2009.

Koch, W. H. Technology platforms for pharmacogenomic diagnostic assays. Nat Rev Drug 
Discov, v.3, n.9, Sep, p.749-61. 2004.

Kojima, T., M. Oh-Eda, et al. Molecular cloning and expression of megakaryocyte potentiating factor cDNA. J Biol Chem, v.270, n.37, Sep 15, p.21984-90. 1995.

Komatsu, N., K. Saijoh, et al. Quantification of human tissue kallikreins in the stratum corneum: dependence on age and gender. J Invest Dermatol, v.125, n.6, Dec, p.1182-9. 2005.

Komine, M., L. S. Rao, et al. Interleukin-1 induces transcription of keratin $\mathrm{K} 6$ in human epidermal keratinocytes. J Invest Dermatol, v.116, n.2, Feb, p.330-8. 2001.

Kreimer, A. R., G. M. Clifford, et al. Human papillomavirus types in head and neck squamous cell carcinomas worldwide: a systematic review. Cancer Epidemiol Biomarkers Prev, v.14, n.2, Feb, p.467-75. 2005.

Ku, N. O., J. Liao, et al. Phosphorylation of human keratin 18 serine 33 regulates binding to 14-3-3 proteins. EMBO J, v.17, n.7, Apr 1, p.1892-906. 1998.

Ku, N. O. e M. B. Omary. A disease- and phosphorylation-related nonmechanical function for keratin 8. J Cell Biol, v.174, n.1, Jul 3, p.115-25. 2006.

Kuriakose, M. A., W. T. Chen, et al. Selection and validation of differentially expressed genes in head and neck cancer. Cell Mol Life Sci, v.61, n.11, Jun, p.1372-83. 2004.

Kuwae, K., K. Matsumoto-Miyai, et al. Epidermal expression of serine protease, neuropsin (KLK8) in normal and pathological skin samples. Mol Pathol, v.55, n.4, Aug, p.235-41. 2002.

Lajer, C. B. e C. Von Buchwald. The role of human papillomavirus in head and neck cancer. APMIS, v.118, n.6-7, Jun, p.510-9.

Lassen, P., J. G. Eriksen, et al. Effect of HPV-associated p16INK4A expression on response to radiotherapy and survival in squamous cell carcinoma of the head and neck. $\mathrm{J}$ Clin Oncol, v.27, n.12, Apr 20, p.1992-8. 2009.

Leong, P. P., B. Rezai, et al. Distinguishing second primary tumors from lung metastases in patients with head and neck squamous cell carcinoma. J Natl Cancer Inst, v.90, n.13, Jul 1, p.972-7. 1998.

Lindberg, K. e J. G. Rheinwald. Suprabasal $40 \mathrm{kd}$ keratin (K19) expression as an immunohistologic marker of premalignancy in oral epithelium. Am J Pathol, v.134, n.1, Jan, p.89-98. 1989.

Lisovsky, M., K. Patel, et al. Immunophenotypic characterization of anal gland carcinoma: loss of p63 and cytokeratin 5/6. Arch Pathol Lab Med, v.131, n.8, Aug, p.1304-11. 2007.

Liu, C. J., T. Y. Liu, et al. Differential gene expression signature between primary and metastatic head and neck squamous cell carcinoma. J Pathol, v.214, n.4, Mar, p.489-97. 2008.

Liu, X., Z. Chen, et al. MicroRNA profiling and head and neck cancer. Comp Funct Genomics, p.837514. 2009.

Llewellyn, C. D., N. W. Johnson, et al. Risk factors for oral cancer in newly diagnosed patients aged 45 years and younger: a case-control study in Southern England. J Oral Pathol 
Med, v.33, n.9, Oct, p.525-32. 2004.

Magin, T. M., P. Vijayaraj, et al. Structural and regulatory functions of keratins. Exp Cell Res, v.313, n.10, Jun 10, p.2021-32. 2007.

Mao, L., J. S. Lee, et al. Frequent microsatellite alterations at chromosomes 9p21 and 3p14 in oral premalignant lesions and their value in cancer risk assessment. Nat Med, v.2, n.6, Jun, p.682-5. 1996.

Margolis, S. S., J. A. Perry, et al. Role for the PP2A/B56delta phosphatase in regulating 143-3 release from Cdc25 to control mitosis. Cell, v.127, n.4, Nov 17, p.759-73. 2006.

Marron, M., P. Boffetta, et al. Cessation of alcohol drinking, tobacco smoking and the reversal of head and neck cancer risk. Int J Epidemiol, v.39, n.1, Feb, p.182-96.

Martin, C. L., S. C. Reshmi, et al. Chromosomal imbalances in oral squamous cell carcinoma: examination of 31 cell lines and review of the literature. Oral Oncol, v.44, n.4, Apr, p.369-82. 2008.

Martone, T., A. Gillio-Tos, et al. Association between hypermethylated tumor and paired surgical margins in head and neck squamous cell carcinomas. Clin Cancer Res, v.13, n.17, Sep 1, p.5089-94. 2007.

Mccaul, J. A., K. E. Gordon, et al. Telomerase inhibition and the future management of headand-neck cancer. Lancet Oncol, v.3, n.5, May, p.280-8. 2002.

Miettinen, M. e M. Sarlomo-Rikala. Expression of calretinin, thrombomodulin, keratin 5, and mesothelin in lung carcinomas of different types: an immunohistochemical analysis of 596 tumors in comparison with epithelioid mesotheliomas of the pleura. Am J Surg Pathol, v.27, n.2, Feb, p.150-8. 2003.

Ministério da Saúde: Estimativa 2009: Incidência de Câncer no Brasil. Rio de Janeiro:. Secretaria de Atenção à Saúde. Instituto Nacional do Câncer; 2007.

Mitsui, S., N. Tsuruoka, et al. A novel form of human neuropsin, a brain-related serine protease, is generated by alternative splicing and is expressed preferentially in human adult brain. Eur J Biochem, v.260, n.3, Mar, p.627-34. 1999.

Moriniere, S. [Epidemiology of head and neck cancer]. Rev Prat, v.56, n.15, Oct 15, p.163741. 2006.

Nathan, C. O., N. Amirghahri, et al. Molecular analysis of surgical margins in head and neck squamous cell carcinoma patients. Laryngoscope, v.112, n.12, Dec, p.2129-40. 2002.

Negri, E., P. Boffetta, et al. Family history of cancer: pooled analysis in the International Head and Neck Cancer Epidemiology Consortium. Int J Cancer, v.124, n.2, Jan 15, p.394401. 2009.

Ohler, A., M. Debela, et al. Analyzing the protease web in skin: meprin metalloproteases are activated specifically by KLK4, 5 and 8 vice versa leading to processing of proKLK7 thereby triggering its activation. Biol Chem, v.391, n.4, Apr, p.455-60.

Omary, M. B., P. A. Coulombe, et al. Intermediate filament proteins and their associated diseases. N Engl J Med, v.351, n.20, Nov 11, p.2087-100. 2004. 
Omary, M. B., N. O. Ku, et al. Keratin modifications and solubility properties in epithelial cells and in vitro. Subcell Biochem, v.31, p.105-40. 1998.

Ordonez, N. G. Application of mesothelin immunostaining in tumor diagnosis. Am J Surg Pathol, v.27, n.11, Nov, p.1418-28. 2003.

Oshima, R. G. Apoptosis and keratin intermediate filaments. Cell Death Differ, v.9, n.5, May, p.486-92. 2002.

Ozbas, S., H. Dafydd, et al. Bone marrow micrometastasis in breast cancer. Br J Surg, v.90, n.3, Mar, p.290-301. 2003.

Paladini, R. D., K. Takahashi, et al. Onset of re-epithelialization after skin injury correlates with a reorganization of keratin filaments in wound edge keratinocytes: defining a potential role for keratin 16. J Cell Biol, v.132, n.3, Feb, p.381-97. 1996.

Pantel, K. e R. H. Brakenhoff. Dissecting the metastatic cascade. Nat Rev Cancer, v.4, n.6, Jun, p.448-56. 2004.

Parikh, R. R., Q. Yang, et al. Outcomes in young women with breast cancer of triple-negative phenotype: the prognostic significance of CK19 expression. Int J Radiat Oncol Biol Phys, v.70, n.1, Jan 1, p.35-42. 2008.

Parkin, D. M., F. Bray, et al. Global cancer statistics, 2002. CA Cancer J Clin, v.55, n.2, MarApr, p.74-108. 2005.

Pera, M. F. e P. A. Gorman. In vitro analysis of multistage epidermal carcinogenesis: development of indefinite renewal capacity and reduced growth factor requirements in colony forming keratinocytes precedes malignant transformation. Carcinogenesis, v.5, n.5, May, p.671-82. 1984.

Perez-Ordonez, B., M. Beauchemin, et al. Molecular biology of squamous cell carcinoma of the head and neck. J Clin Pathol, v.59, n.5, May, p.445-53. 2006.

Pettus, J. R., J. J. Johnson, et al. Multiple kallikrein (KLK 5, 7, 8, and 10) expression in squamous cell carcinoma of the oral cavity. Histol Histopathol, v.24, n.2, Feb, p.197-207. 2009.

Pfaffl, M. W. A new mathematical model for relative quantification in real-time RT-PCR. Nucleic Acids Res, v.29, n.9, May 1, p.e45. 2001.

Pignataro, L., G. Pruneri, et al. Clinical relevance of cyclin D1 protein overexpression in laryngeal squamous cell carcinoma. J Clin Oncol, v.16, n.9, Sep, p.3069-77. 1998.

Pim, D. e L. Banks. Interaction of viral oncoproteins with cellular target molecules: infection with high-risk vs low-risk human papillomaviruses. APMIS, v.118, n.6-7, Jun, p.471-93.

Pim, D., V. Tomaic, et al. The human papillomavirus (HPV) E6* proteins from high-risk, mucosal HPVs can direct degradation of cellular proteins in the absence of full-length E6 protein. J Virol, v.83, n.19, Oct, p.9863-74. 2009.

Prieve, M. G. e R. T. Moon. Stromelysin-1 and mesothelin are differentially regulated by Wnt5a and Wnt-1 in C57mg mouse mammary epithelial cells. BMC Dev Biol, v.3, Apr 7, p.2. 2003. 
Rajapakse, S., K. Ogiwara, et al. Biochemical characterization of human kallikrein 8 and its possible involvement in the degradation of extracellular matrix proteins. FEBS Lett, v.579, n.30, Dec 19, p.6879-84. 2005.

Ram Prassad, V. V., N. R. Nirmala, et al. Immunohistochemical evaluation of expression of cytokeratin 19 in different histological grades of leukoplakia and oral squamous cell carcinoma. Indian J Dent Res, v.16, n.1, Jan-Mar, p.6-11. 2005.

Rheinwald, J. G. e H. Green. Serial cultivation of strains of human epidermal keratinocytes: the formation of keratinizing colonies from single cells. Cell, v.6, n.3, Nov, p.331-43. 1975.

Rheinwald, J. G. e H. Green. Epidermal growth factor and the multiplication of cultured human epidermal keratinocytes. Nature, v.265, n.5593, Feb 3, p.421-4. 1977.

Rocco, J. W. e D. Sidransky. p16(MTS-1/CDKN2/INK4a) in cancer progression. Exp Cell

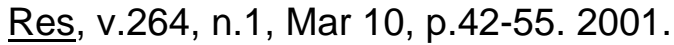

Rodriguez, T., A. Altieri, et al. Risk factors for oral and pharyngeal cancer in young adults. Oral Oncol, v.40, n.2, Feb, p.207-13. 2004.

Roepman, P., L. F. Wessels, et al. An expression profile for diagnosis of lymph node metastases from primary head and neck squamous cell carcinomas. Nat Genet, v.37, n.2, Feb, p.182-6. 2005.

Rosenblatt, K. A., J. R. Daling, et al. Marijuana use and risk of oral squamous cell carcinoma. Cancer Res, v.64, n.11, Jun 1, p.4049-54. 2004.

Rubin Grandis, J., M. F. Melhem, et al. Levels of TGF-alpha and EGFR protein in head and neck squamous cell carcinoma and patient survival. J Natl Cancer Inst, v.90, n.11, Jun 3, p.824-32. 1998.

Rump, A., Y. Morikawa, et al. Binding of ovarian cancer antigen CA125/MUC16 to mesothelin mediates cell adhesion. J Biol Chem, v.279, n.10, Mar 5, p.9190-8. 2004.

Safer, J. D., T. M. Crawford, et al. A role for thyroid hormone in wound healing through keratin gene expression. Endocrinology, v.145, n.5, May, p.2357-61. 2004.

Saintigny, P., S. Coulon, et al. Real-time RT-PCR detection of CK19, CK7 and MUC1 mRNA for diagnosis of lymph node micrometastases in non small cell lung carcinoma. Int J Cancer, v.115, n.5, Jul 10, p.777-82. 2005.

Sapkota, A., C. C. Hsu, et al. Dietary risk factors for squamous cell carcinoma of the upper aerodigestive tract in central and eastern Europe. Cancer Causes Control, v.19, n.10, Dec, p.1161-70. 2008.

Schmelz, M., R. Moll, et al. Identification of a stem cell candidate in the normal human prostate gland. Eur J Cell Biol, v.84, n.2-3, Mar, p.341-54. 2005.

Schmitt, A. M., M. Anlauf, et al. WHO 2004 criteria and CK19 are reliable prognostic markers in pancreatic endocrine tumors. Am J Surg Pathol, v.31, n.11, Nov, p.1677-82. 2007.

Scholes, A. G., J. A. Woolgar, et al. Synchronous oral carcinomas: independent or common clonal origin? Cancer Res, v.58, n.9, May 1, p.2003-6. 1998.

Schweizer, J., P. E. Bowden, et al. New consensus nomenclature for mammalian keratins. $\underline{\mathrm{J}}$ 
Cell Biol, v.174, n.2, Jul 17, p.169-74. 2006.

Scott, F. L., J. Sun, et al. SerpinB6 is an inhibitor of kallikrein-8 in keratinocytes. J Biochem, v.142, n.4, Oct, p.435-42. 2007.

Sedaghat, A. R., Z. Zhang, et al. Prognostic significance of human papillomavirus in oropharyngeal squamous cell carcinomas. Laryngoscope, v.119, n.8, Aug, p.1542-9. 2009.

Severino, P., A. M. Alvares, et al. Global gene expression profiling of oral cavity cancers suggests molecular heterogeneity within anatomic subsites. BMC Res Notes, v.1, p.113. 2008.

Shaw, J. L. e E. P. Diamandis. Regulation of human tissue kallikrein-related peptidase expression by steroid hormones in 32 cell lines. Biol Chem, v.389, n.11, Nov, p.1409-19. 2008.

Sher, Y. P., C. C. Chou, et al. Human kallikrein 8 protease confers a favorable clinical outcome in non-small cell lung cancer by suppressing tumor cell invasiveness. Cancer Res, v.66, n.24, Dec 15, p.11763-70. 2006.

Shigemasa, K., X. Tian, et al. Human kallikrein 8 (hK8/TADG-14) expression is associated with an early clinical stage and favorable prognosis in ovarian cancer. Oncol Rep, v.11, n.6, Jun, p.1153-9. 2004.

Shimizu-Okabe, C., G. M. Yousef, et al. Expression of the kallikrein gene family in normal and Alzheimer's disease brain. Neuroreport, v.12, n.12, Aug 28, p.2747-51. 2001.

Silveira, N. J., L. Varuzza, et al. Searching for molecular markers in head and neck squamous cell carcinomas (HNSCC) by statistical and bioinformatic analysis of larynxderived SAGE libraries. BMC Med Genomics, v.1, p.56. 2008.

Slaughter, D. P., H. W. Southwick, et al. Field cancerization in oral stratified squamous epithelium; clinical implications of multicentric origin. Cancer, v.6, n.5, Sep, p.963-8. 1953.

Smith, E. M., J. M. Ritchie, et al. Age, sexual behavior and human papillomavirus infection in oral cavity and oropharyngeal cancers. Int J Cancer, v.108, n.5, Feb 20, p.766-72. 2004.

Smith, E. M., L. M. Rubenstein, et al. Does pretreatment seropositivity to human papillomavirus have prognostic significance for head and neck cancers? Cancer Epidemiol Biomarkers Prev, v.17, n.8, Aug, p.2087-96. 2008.

Smith Fjd, K. R., Schwartz Me,Mclean Whi, Leachman Sa. Pachyonychia congenita. GeneReviews. 2006.

Stathopoulou, A., I. Vlachonikolis, et al. Molecular detection of cytokeratin-19-positive cells in the peripheral blood of patients with operable breast cancer: evaluation of their prognostic significance. J Clin Oncol, v.20, n.16, Aug 15, p.3404-12. 2002.

Steeg, P. S. e D. Theodorescu. Metastasis: a therapeutic target for cancer. Nat Clin Pract Oncol, v.5, n.4, Apr, p.206-19. 2008.

Stubbs, M. T., M. Renatus, et al. An active zymogen: unravelling the mystery of tissue-type plasminogen activator. Biol Chem, v.379, n.2, Feb, p.95-103. 1998.

Sturgis, E. M. e Q. Wei. Genetic susceptibility--molecular epidemiology of head and neck 
cancer. Curr Opin Oncol, v.14, n.3, May, p.310-7. 2002.

Suarez, C., J. P. Rodrigo, et al. Tumours of familial origin in the head and neck. Oral Oncol, v.42, n.10, Nov, p.965-78. 2006.

Sun, T. T. e H. Green. Differentiation of the epidermal keratinocyte in cell culture: formation of the cornified envelope. Cell, v.9, n.4 Pt 1, Dec, p.511-21. 1976.

Syrjanen, K., S. Syrjanen, et al. Morphological and immunohistochemical evidence suggesting human papillomavirus (HPV) involvement in oral squamous cell carcinogenesis. Int J Oral Surg, v.12, n.6, Dec, p.418-24. 1983.

Takahashi, K., R. D. Paladini, et al. Cloning and characterization of multiple human genes and cDNAs encoding highly related type II keratin 6 isoforms. J Biol Chem, v.270, n.31, Aug 4, p.18581-92. 1995.

Tani, N., K. Matsumoto, et al. Effects of fibronectin cleaved by neuropsin on cell adhesion and migration. Neurosci Res, v.39, n.2, Feb, p.247-51. 2001.

Tao, L., M. Lefevre, et al. Detection of occult carcinomatous diffusion in lymph nodes from head and neck squamous cell carcinoma using real-time RT-PCR detection of cytokeratin 19 mRNA. Br J Cancer, v.94, n.8, Apr 24, p.1164-9. 2006.

Tischkowitz, M., J. S. Brunet, et al. Use of immunohistochemical markers can refine prognosis in triple negative breast cancer. BMC Cancer, v.7, p.134. 2007.

Trizna, Z. e S. P. Schantz. Hereditary and environmental factors associated with risk and progression of head and neck cancer. Otolaryngol Clin North Am, v.25, n.5, Oct, p.1089-103. 1992.

Trost, A., P. Desch, et al. Aberrant heterodimerization of keratin 16 with keratin $6 \mathrm{~A}$ in HaCaT keratinocytes results in diminished cellular migration. Mech Ageing Dev, v.131, n.5, May, p.346-53.

Uehara, N., Y. Matsuoka, et al. Mesothelin promotes anchorage-independent growth and prevents anoikis via extracellular signal-regulated kinase signaling pathway in human breast cancer cells. Mol Cancer Res, v.6, n.2, Feb, p.186-93. 2008.

Underwood, L. J., H. Tanimoto, et al. Cloning of tumor-associated differentially expressed gene-14, a novel serine protease overexpressed by ovarian carcinoma. Cancer Res, v.59, n.17, Sep 1, p.4435-9. 1999.

Van Der Velden, L. A., J. J. Manni, et al. Expression of intermediate filament proteins in benign lesions of the oral mucosa. Eur Arch Otorhinolaryngol, v.256, n.10, p.514-9. 1999.

Vincent-Salomon, A., F. C. Bidard, et al. Bone marrow micrometastasis in breast cancer: review of detection methods, prognostic impact and biological issues. J Clin Pathol, v.61, n.5, May, p.570-6. 2008.

Vineis, P., M. Alavanja, et al. Tobacco and cancer: recent epidemiological evidence. J Natl Cancer Inst, v.96, n.2, Jan 21, p.99-106. 2004.

Vora, H. H., N. G. Shah, et al. Prognostic significance of biomarkers in squamous cell carcinoma of the tongue: multivariate analysis. J Surg Oncol, v.82, n.1, Jan, p.34-50. 2003. 
Windoffer, R., A. Kolsch, et al. Focal adhesions are hotspots for keratin filament precursor formation. J Cell Biol, v.173, n.3, May 8, p.341-8. 2006.

Wojcik, S. M., M. A. Longley, et al. Discovery of a novel murine keratin 6 (K6) isoform explains the absence of hair and nail defects in mice deficient for K6a and K6b. J Cell Biol, v.154, n.3, Aug 6, p.619-30. 2001.

Wöll, S., R. Windoffer, et al. Dissection of keratin dynamics: different contributions of the actin and microtubule systems. Eur J Cell Biol, v.84, n.2-3, Mar, p.311-28. 2005.

Wong, P., E. Colucci-Guyon, et al. Introducing a null mutation in the mouse K6alpha and K6beta genes reveals their essential structural role in the oral mucosa. J Cell Biol, v.150, n.4, Aug 21, p.921-8. 2000.

Wong, P. e P. A. Coulombe. Loss of keratin 6 (K6) proteins reveals a function for intermediate filaments during wound repair. J Cell Biol, v.163, n.2, Oct 27, p.327-37. 2003.

Worsham, M. J., S. R. Wolman, et al. Common clonal origin of synchronous primary head and neck squamous cell carcinomas: analysis by tumor karyotypes and fluorescence in situ hybridization. Hum Pathol, v.26, n.3, Mar, p.251-61. 1995.

Xenidis, N., M. Perraki, et al. Predictive and prognostic value of peripheral blood cytokeratin19 mRNA-positive cells detected by real-time polymerase chain reaction in node-negative breast cancer patients. J Clin Oncol, v.24, n.23, Aug 10, p.3756-62. 2006.

$\mathrm{Xu}, \mathrm{Y} ., \mathrm{M}$. Lefevre, et al. Clinical significance of micrometastases detection in lymph nodes from head and neck squamous cell carcinoma. Otolaryngol Head Neck Surg, v.139, n.3, Sep, p.436-41. 2008.

Yoshida, S., M. Taniguchi, et al. Sequence analysis and expression of human neuropsin cDNA and gene. Gene, v.213, n.1-2, Jun 15, p.9-16. 1998.

Yousef, G. M., C. A. Borgono, et al. In-silico analysis of kallikrein gene expression in pancreatic and colon cancers. Anticancer Res, v.24, n.1, Jan-Feb, p.43-51. 2004.

Yousef, G. M. e E. P. Diamandis. The new human tissue kallikrein gene family: structure, function, and association to disease. Endocr Rev, v.22, n.2, Apr, p.184-204. 2001.

Yousef, G. M., G. M. Yacoub, et al. Kallikrein gene downregulation in breast cancer. $\mathrm{Br} \mathrm{J}$ Cancer, v.90, n.1, Jan 12, p.167-72. 2004.

Zhang, D. H., L. K. Tai, et al. Proteomics of breast cancer: enhanced expression of cytokeratin19 in human epidermal growth factor receptor type 2 positive breast tumors. Proteomics, v.5, n.7, May, p.1797-805. 2005.

Zhang, Z. F., H. Morgenstern, et al. Marijuana use and increased risk of squamous cell carcinoma of the head and neck. Cancer Epidemiol Biomarkers Prev, v.8, n.12, Dec, p.10718. 1999. 
Anexo 1 
Tabela 1. Valores médios de Cts dos padrões internos obtidos de triplicatas de pools de amostras de margens cirúrgicas e de amostras individuais de tumores primários, distribuídos por sítios anatômicos.

\begin{tabular}{|c|c|c|c|c|}
\hline \multicolumn{5}{|c|}{ Genes de Referência } \\
\hline \multicolumn{5}{|c|}{ Pools de Margem Cirúrgica } \\
\hline & GAPDH & $B$-actina & HPRT1 & $B C R$ \\
\hline Língua NO & 22,31 & 22,5318 & 31,75487 & 28,9181 \\
\hline Língua N+ & 22,8399 & 22,5679 & 32,35373 & 30,10287 \\
\hline Laringe NO & 23,5892 & 24,1489 & 33,0073 & 29,3093 \\
\hline Laringe $\mathrm{N}+$ & 23,1691 & 23,94345 & 32,51197 & 28,58153 \\
\hline \multicolumn{5}{|c|}{ Língua } \\
\hline Amostras & GAPDH & $B$-actina & HPRT1 & $B C R$ \\
\hline CP1/0021 T & 22,74347 & 22,1319 & 30,2062 & 25,98607 \\
\hline CP1/0021 M & 22,00467 & 22,28807 & 30,91615 & 27,69877 \\
\hline CP1/0057 T & 19,38033 & 18,56217 & 28,2887 & 26,72127 \\
\hline CP1/0057 M & 19,1326 & 19,3835 & 29,73075 & 26,29843 \\
\hline CP1/0151 T & 25,52553 & 25,493 & 33,8129 & 29,1591 \\
\hline CP1/0151 M & 24,88907 & 23,32613 & 32,7402 & 27,72693 \\
\hline CP1/0200 T & 23,80123 & 22,95957 & 27,7259 & 26,3063 \\
\hline CP1/0200 M & 25,27007 & 27,41553 & 33,81575 & 30,5194 \\
\hline CP1/0262 T & 23,63657 & 27,26953 & 32,93385 & 29,5928 \\
\hline CP1/0262 M & 20,45557 & 20,441 & 26,35053 & 24,78877 \\
\hline CP2/1002 T & 21,6187 & 25,7048 & 31,70837 & 29,92027 \\
\hline CP2/1002 M & 22,9256 & 23,12083 & 29,25303 & 26,5365 \\
\hline СР3/0049 T & 25,49923 & 25,95905 & 32,86697 & 28,34027 \\
\hline CP3/0049 M & 33,3056 & 34,0435 & N/A & 36,7351 \\
\hline CP3/0050 T & 24,46467 & 25,5173 & 33,15885 & 27,20947 \\
\hline CP3/0050 M & 26,3539 & 28,30647 & 34,3323 & 29,8307 \\
\hline CP3/0087 T & 24,63283 & 26,08733 & 32,65447 & 28,80863 \\
\hline CP3/0087 M & N/A & N/A & 29,71413 & 25,7263 \\
\hline CP3/0118 T & 18,2743 & 19,2564 & 27,75207 & 26,51283 \\
\hline CP3/0118 M & 21,19337 & 21,00943 & 30,58703 & 27,65943 \\
\hline \multicolumn{5}{|c|}{ Soalho de Boca } \\
\hline Amostras & GAPDH & $B$-actina & HPRT1 & $B C R$ \\
\hline CP2/0168 T & 24,95405 & 23,9104 & 28,20855 & 25,38993 \\
\hline CP2/0168 M & 25,12685 & 25,55677 & 29,77883 & 28,67557 \\
\hline CP1/0089 T & 21,78983 & 21,67723 & 28,0993 & 26,04685 \\
\hline CP1/0089 M & 27,18683 & 26,1355 & 33,09003 & 30,2544 \\
\hline CP1/0255 T & 21,9962 & 22,24413 & 28,0562 & 26,01285 \\
\hline CP1/0255 M & 33,44743 & 32,22473 & N/A & 35,5094 \\
\hline CP1/0240 T & 22,42433 & 22,2786 & 28,34435 & 25,37577 \\
\hline CP1/0240 M & 25,72567 & 25,50783 & 33,06685 & 28,34637 \\
\hline CP3/0033 T & 21,12103 & 21,9857 & 28,4253 & 25,03107 \\
\hline CP3/0033 M & 24,85897 & 28,92507 & 33,94517 & 31,98085 \\
\hline СР3/0120 T & 26,83117 & 27,6223 & 33,8498 & 30,20203 \\
\hline
\end{tabular}




\begin{tabular}{|c|c|c|c|c|}
\hline CP3/0120 M & 25,171 & 24,2125 & 32,05815 & 28,0622 \\
\hline CP1/0080 T & 22,56733 & F/A & 27,5865 & 24,56877 \\
\hline CP1/0080 M & 23,5823 & F/A & 29,9793 & 28,7785 \\
\hline CP1/0191 T & 22,95 & 22,3084 & 27,63323 & 26,1966 \\
\hline CP1/0191 M & 22,9242 & 23,5004 & 30,55525 & 25,8525 \\
\hline CP1/0024 T & 20,86217 & 21,35137 & 27,46025 & 25,12255 \\
\hline CP1/0024 M & 21,4844 & 22,63003 & 27,99283 & 26,88627 \\
\hline CP1/0075 T & 25,1092 & 23,4792 & 28,9242 & 26,4428 \\
\hline CP1/0075 M & 25,16465 & 24,9188 & 27,97793 & 26,97097 \\
\hline CP1/0083 T & 24,9719 & 26,38065 & 33,1619 & 29,21997 \\
\hline CP1/0083 M & 26,40985 & 27,6316 & 36,3211 & 30,32493 \\
\hline CP1/0384 T & 18,71467 & 19,7819 & 27,436 & 25,308 \\
\hline CP1/0384 M & 21,81937 & 23,49303 & 31,704 & 28,94383 \\
\hline CP1/0366 T & 19,8604 & 20,68913 & 28,827 & 27,68017 \\
\hline CP1/0366 M & 20,88803 & 20,26163 & 29,26347 & 27,23033 \\
\hline CP1/0370 T & 21,53627 & 21,81237 & 30,89313 & 28,82337 \\
\hline CP1/0370 M & 21,2413 & 25,0032 & 33,23685 & 30,6621 \\
\hline CP2/0051 T & 22,3635 & 22,1888 & 27,7329 & 25,64937 \\
\hline CP2/0051 M & 24,1701 & 24,34137 & 30,86743 & 28,35927 \\
\hline CP2/0122 T & 19,22655 & 19,1161 & 27,2361 & 24,3988 \\
\hline CP2/0122 M & 22,14283 & 24,37543 & 31,78693 & 29,45073 \\
\hline CP1/0258 T & 25,27837 & 24,65663 & 31,6325 & 26,8638 \\
\hline CP1/0258 M & 29,5746 & 30,18147 & 36,60733 & 33,12183 \\
\hline СР3/0280 T & 19,01147 & 21,0191 & 28,43417 & 26,5003 \\
\hline CP3/0280 M & 22,19433 & 22,32943 & 30,883 & 28,90483 \\
\hline CP1/0032 T & 20,20197 & 19,71567 & 28,0564 & 24,9807 \\
\hline CP1/0032 M & 23,8245 & 23,68467 & 30,8055 & 27,68993 \\
\hline CP1/0213 T & 20,22103 & 19,67073 & 27,40387 & 25,42317 \\
\hline CP1/0213 M & 20,71407 & 19,22877 & 26,24657 & 25,2202 \\
\hline CP1/0233 T & 20,1105 & 21,00353 & 27,27707 & 25,0098 \\
\hline CP1/0233 M & 23,33703 & 25,12667 & 32,05397 & 27,33057 \\
\hline CP1/0055 T & 34,2565 & 24,3873 & 36,2 & 35,54195 \\
\hline CP1/0055 M & 28,5615 & 28,6144 & 37,11843 & 32,166 \\
\hline CP1/0363 T & 18,10227 & 19,03747 & 28,01603 & 24,8956 \\
\hline CP1/0363 M & 21,38343 & 23,07787 & 31,79367 & 29,1204 \\
\hline CP1/0228 T & 18,73853 & 18,85983 & 27,18307 & 25,43383 \\
\hline CP1/0228 M & 20,61723 & 21,0478 & 30,3154 & 27,5631 \\
\hline \multicolumn{5}{|c|}{ Laringe } \\
\hline & GAPDH & $B$-actina & HPRT1 & $B C R$ \\
\hline СР1/0056 T & 26,24163 & 25,25233 & 31,80195 & 31,1849 \\
\hline CP1/0056 M & 26,35547 & 26,27375 & 34,20343 & 31,4337 \\
\hline CP1/0357 T & 22,75293 & 25,2537 & 31,4019 & 28,67267 \\
\hline CP1/0357 M & 21,78193 & 22,6017 & 28,9993 & 26,0443 \\
\hline CP1/0359 T & 18,75187 & 18,37697 & 23,83497 & 23,59817 \\
\hline CP1/0359 M & 21,37317 & 22,64973 & 29,18977 & 25,7567 \\
\hline CP1/0385 T & 20,07777 & 20,9167 & 26,53307 & 24,0986 \\
\hline
\end{tabular}




\begin{tabular}{|c|c|c|c|c|}
\hline CP1/0385 M & 22,47417 & 24,57693 & 30,78513 & 26,81143 \\
\hline CP3/0035 T & 25,66513 & 26,29237 & 33,00237 & 31,29257 \\
\hline CP3/0035 M & 21,2552 & 22,29523 & 28,23937 & 25,08337 \\
\hline CP1/0348 T & 25,3129 & 25,1589 & 33,28257 & 31,107 \\
\hline CP1/0348 M & 27,04703 & 27,05763 & 34,8922 & 32,865 \\
\hline СР3/0019 T & 26,28637 & 26,87775 & 34,17377 & 31,273 \\
\hline CP3/0019 M & 32,9894 & 32,5996 & $N / A$ & 33,7703 \\
\hline CP3/0096 T & 31,64805 & 32,36165 & $\mathrm{~N} / \mathrm{A}$ & 36,69205 \\
\hline CP3/0096 M & 33,51757 & 33,85043 & $\mathrm{~N} / \mathrm{A}$ & 36,16645 \\
\hline СР3/0199 T & 30,0314 & 29,4649 & 37,89145 & 34,7163 \\
\hline CP3/0199 M & 28,3581 & 27,5325 & 35,38545 & 33,44815 \\
\hline СР3/0249 T & 26,0326 & 25,57187 & 31,4707 & 30,46955 \\
\hline СР3/0249 M & 31,94797 & 31,3752 & $N / A$ & 34,56745 \\
\hline CP4/0016 T & 19,20867 & 21,12633 & 27,25525 & 23,9645 \\
\hline CP4/0016 M & 21,1281 & 24,35223 & 31,39415 & 26,30125 \\
\hline СР3/0377 T & 18,71903 & 20,07903 & 27,87895 & 26,29815 \\
\hline CP3/0377 M & 19,1972 & 25,0271 & 32,23565 & 29,36 \\
\hline CP4/0024 T & 20,31837 & 21,35137 & 28,72645 & 25,9249 \\
\hline CP4/0024 M & 20,76373 & 22,63003 & 30,38695 & 26,9413 \\
\hline CP3/0390 T & 20,03163 & 20,95287 & 25,952 & 24,81075 \\
\hline СР3/0390 M & 25,81037 & 27,6056 & 33,9751 & 28,8787 \\
\hline CP3/0433 T & 18,5484 & 19,84037 & 26,7727 & 25,0825 \\
\hline CP3/0433 M & 23,18563 & 25,3469 & 31,98875 & 27,58865 \\
\hline CP2/0096 T & 20,61253 & 20,39857 & 27,47873 & 24,33083 \\
\hline CP2/0096 M & 24,20477 & 24,20747 & 31,4189 & 26,5818 \\
\hline CP3/0018 T & 23,8894 & 24,40143 & 33,6928 & 29,4177 \\
\hline CP3/0018 M & 21,24847 & 21,99267 & 31,6841 & 27,4792 \\
\hline CP3/0031 T & 21,22193 & 20,7227 & 30,2082 & 26,26887 \\
\hline CP3/0031 M & 19,75697 & 20,0679 & 29,30863 & 25,31987 \\
\hline СР3/0102 T & 19,50703 & 20,58493 & 26,75513 & 25,8197 \\
\hline CP3/0102 M & 21,4772 & 22,5008 & 29,82863 & 26,3128 \\
\hline СР3/0105 T & 23,07267 & 23,27827 & 31,059 & 28,06023 \\
\hline CP3/0105 M & 29,35597 & 32,921 & $N / A$ & 34,02975 \\
\hline CP3/0125 T & 29,24187 & 31,5084 & N/A & 32,97313 \\
\hline CP3/0125 M & 26,5627 & 31,9394 & N/A & 32,3477 \\
\hline CP3/0136 T & 20,3875 & 20,9208 & 27,79805 & 24,2215 \\
\hline CP3/0136 M & 34,2568 & 35,42555 & $\mathrm{~N} / \mathrm{A}$ & 37,63517 \\
\hline СР3/0153 T & 20,02847 & 20,5384 & 29,73755 & 25,37757 \\
\hline CP3/0153 M & 21,57087 & 23,40293 & 31,23957 & 25,7352 \\
\hline $\mathrm{CP} 4 / 0001 \mathrm{~T}$ & 19,2399 & 19,34677 & 27,2692 & 24,711 \\
\hline CP4/0001 M & 25,5842 & 26,73093 & N/A & 30,24683 \\
\hline CP3/0085 T & 20,79913 & 22,37303 & 28,5658 & 24,92445 \\
\hline CP3/0085 M & 21,99337 & 23,1393 & 29,0869 & 25,5986 \\
\hline CP3/0464 T & 22,30003 & 23,7969 & 28,08305 & 24,296 \\
\hline CP3/0464 M & 23,8508 & 25,26627 & 31,141 & 27,01675 \\
\hline СР3/0076 Т & 21,0259 & 24,47843 & 30,7779 & 27,7402 \\
\hline СР3/0076 M & 24,26223 & 26,8304 & 32,7535 & 28,6607 \\
\hline
\end{tabular}




\begin{tabular}{|l|c|c|c|c|}
\hline CP3/0119 T & 24,53923 & 26,12327 & 30,75955 & 26,13855 \\
\hline CP3/0119 M & 25,3065 & 27,96987 & 32,31965 & 28,01435 \\
\hline CP3/0411 T & 20,62263 & 20,97877 & 27,3251 & 25,13705 \\
\hline CP3/0411 M & 22,0148 & 22,8309 & 29,6862 & 25,4584 \\
\hline
\end{tabular}


Tabela 2. Valores de quantificação relativa da expressão do gene $K R T 6 A$, tendo como padrão interno o gene GAPDH.

\begin{tabular}{|c|c|c|c|c|c|}
\hline \multicolumn{6}{|c|}{ Gene KRT6A } \\
\hline \multicolumn{6}{|c|}{ LÍNGUA } \\
\hline Amostras & média Ct $K R T 6 A$ & $\left(E_{K R T G A}\right)^{\Delta C t(M C-A T)}$ & $\left(E_{G A P D H}\right)^{\Delta C t(M C-A T)}$ & $\begin{array}{c}\text { Expressão } \\
\text { Relativa }\end{array}$ & $\log _{3}$ \\
\hline CP1/0021 T & 18,78856667 & 11,89616036 & 0,601460827 & 19,7787783 & 2,7167087 \\
\hline CP1/0021 M & 22,31043333 & & & & \\
\hline CP1/0057 T & 19,92106667 & 0,938879772 & 0,843265109 & 1,113386243 & 0,09776519 \\
\hline CP1/0057 M & 19,83136667 & & & & \\
\hline CP1/0151 T & 23,18436667 & 0,175141957 & 0,645342071 & 0,271393986 & $-1,1871192$ \\
\hline CP1/0151 M & 20,70653333 & & & & \\
\hline CP1/0200 T & 22,07176667 & 1,781371684 & 2,747674988 & 0,648319649 & $-0,3944717$ \\
\hline CP1/0200 M & 22,89296667 & & & & \\
\hline CP1/0262 T & 22,0171 & 0,210558075 & 0,112033619 & 1,879418669 & 0,57432683 \\
\hline CP1/0262 M & 19,8012 & & & & \\
\hline $\mathrm{CP} 2 / 1002 \mathrm{~T}$ & 29,26526667 & 0,006970968 & 2,457938915 & 0,002836103 & $-5,3388483$ \\
\hline CP2/1002 M & 22,20223333 & & & & \\
\hline CP3/0049 T & 21,54826667 & 153,7786248 & 215,2567079 & 0,714396435 & $-0,3061291$ \\
\hline CP3/0049 M & 28,71016667 & & & & \\
\hline СР3/0050 T & 15,66936667 & 220,6190495 & 3,669468752 & 60,12288547 & 3,72869537 \\
\hline CP3/0050 M & 23,3446 & & & & \\
\hline CP3/0087 T & 23,1082 & 0,054522803 & - & - & - \\
\hline CP3/0087 M & 18,9706 & & & & \\
\hline CP3/0118 T & 19,77156667 & 0,301328374 & 7,45370248 & 0,040426671 & $-2,9202892$ \\
\hline CP3/0118 M & 18,06546667 & & & & \\
\hline \multirow{2}{*}{\multicolumn{6}{|c|}{ SOALHO DE BOCA }} \\
\hline & & & & & \\
\hline Amostras & média Ct $K R T 6 A$ & $\left(E_{K R T G A}\right)^{\Delta C t(M C-A T)}$ & $\left(\mathrm{E}_{\mathrm{GAPDH}}\right)^{\Delta \mathrm{Ct}(\mathrm{MC}-\mathrm{AT})}$ & $\begin{array}{c}\text { Expressão } \\
\text { Relativa }\end{array}$ & $\log _{3}$ \\
\hline CP2/0168 T & 21,65066667 & 2,213023253 & 1,126268173 & 1,964916799 & 0,614821 \\
\hline CP2/0168 M & 22,78046667 & & & & \\
\hline CP1/0089 T & 19,76466667 & 26,67115278 & 41,01191545 & 0,650326923 & $-0,3916578$ \\
\hline CP1/0089 M & 24,43483333 & & & & \\
\hline CP1/0255 T & 20,6314 & 1637,723108 & 2643,846948 & 0,619447018 & $-0,4359391$ \\
\hline CP1/0255 M & 31,15776667 & & & & \\
\hline CP1/0240 T & 22,63793333 & 5,641153748 & 9,696469214 & 0,581774007 & $-0,4930522$ \\
\hline CP1/0240 M & 25,0986 & & & & \\
\hline CP3/0033 T & 18,70256667 & 101,6923532 & 13,09461928 & 7,765964863 & 1,8657635 \\
\hline CP3/0033 M & 25,27626667 & & & & \\
\hline CP3/0120 T & 23,28823333 & 0,428770238 & 0,319046573 & 1,343911122 & 0,26905225 \\
\hline CP3/0120 M & 22,0838 & & & & \\
\hline CP1/0080 T & 17,94366667 & 1,049832798 & 2,010601077 & 0,522148729 & $-0,591476$ \\
\hline CP1/0080 M & 18,01283333 & & & & \\
\hline CP1/0191 T & 19,9497 & 0,231289898 & 0,982402798 & 0,235432858 & $-1,3165059$ \\
\hline CP1/0191 M & 17,86736667 & & & & \\
\hline CP1/0024 T & 17,4335 & 8,685252094 & 1,534462735 & 5,660125786 & 1,57785065 \\
\hline CP1/0024 M & 20,50793333 & & & & \\
\hline CP1/0075 T & 21,11923333 & 0,858114743 & 1,038894395 & 0,825988423 & $-0,1740145$ \\
\hline
\end{tabular}




\begin{tabular}{|c|c|c|c|c|c|}
\hline CP1/0075 M & 20,9016 & & & & \\
\hline CP1/0083 T & 21,95566667 & 1,223274382 & 2,689897809 & 0,454766117 & $-0,717243$ \\
\hline CP1/0083 M & 22,2423 & & & & \\
\hline CP1/0384 T & 19,62996667 & 11,97644721 & 8,469331779 & 1,414095884 & 0,31538913 \\
\hline CP1/0384 M & 23,1614 & & & & \\
\hline CP1/0366 T & 19,22756667 & 8,786803302 & 2,028202824 & 4,332309963 & 1,33450253 \\
\hline CP1/0366 M & 22,31853333 & & & & \\
\hline CP1/0370 T & 20,64133333 & 12,02538647 & 0,816297195 & 14,73162782 & 2,44854055 \\
\hline CP1/0370 M & 24,17856667 & & & & \\
\hline CP2/0051 T & 18,7702 & 6,401928599 & 3,466633806 & 1,846727678 & 0,55835462 \\
\hline CP2/0051 M & 21,4108 & & & & \\
\hline CP2/0122 T & 21,30286667 & 57,48259617 & 7,439440006 & 7,726736974 & 1,86115399 \\
\hline CP2/0122 M & 27,0652 & & & & \\
\hline CP1/0258 T & 22,45376667 & 55,04999265 & 19,22837346 & 2,862956285 & 0,95743946 \\
\hline CP1/0258 M & 28,1546 & & & & \\
\hline СР3/0280 T & 23,2411 & 1,086173349 & 8,937365007 & 0,121531721 & $-1,918402$ \\
\hline CP3/0280 M & 23,35866667 & & & & \\
\hline CP1/0032 T & 19,8925 & 2,501078333 & 12,09498213 & 0,206786443 & $-1,4345995$ \\
\hline CP1/0032 M & 21,19633333 & & & & \\
\hline CP1/0213 T & 19,94823333 & 4,391490595 & 1,403927007 & 3,128004928 & 1,03803263 \\
\hline CP1/0213 M & 22,05273333 & & & & \\
\hline CP1/0233 T & 30,26316667 & 0,001855187 & 9,20999539 & 0,000201432 & $-7,7461896$ \\
\hline CP1/0233 M & 21,31736667 & & & & \\
\hline CP1/0055 T & 27,11686667 & 0,068603559 & 0,0198624 & 3,453941 & 1,12825599 \\
\hline CP1/0055 M & 23,306 & & & & \\
\hline CP1/0363 T & 19,23833333 & 28,87459868 & 9,562836985 & 3,019459469 & 1,00588519 \\
\hline CP1/0363 M & 24,0214 & & & & \\
\hline CP1/0228 T & 18,27023333 & 5,058457639 & 3,642967314 & 1,38855422 & 0,29879793 \\
\hline CP1/0228 M & 20,57583333 & & & & \\
\hline \multicolumn{6}{|c|}{ LARINGE } \\
\hline Amostras & média Ct KRT6A & $\left(E_{\text {KRT6A }}\right)^{\Delta \mathrm{Ct}(\mathrm{MC}-\mathrm{AT})}$ & $\left(E_{G A P D H}\right)^{\Delta C t(M C-A T)}$ & $\begin{array}{c}\text { Expressão } \\
\text { Relativa }\end{array}$ & $\log _{3}$ \\
\hline CP1/0056 T & 24,5263 & 0,603173409 & 1,081482364 & 0,557728381 & $-0,5314734$ \\
\hline CP1/0056 M & 23,80726667 & & & & \\
\hline CP1/0357 T & 20,96946667 & 1,51010502 & 0,512641384 & 2,945733735 & 0,98338417 \\
\hline CP1/0357 M & 21,5557 & & & & \\
\hline CP1/0359 T & 16,42383333 & 9,35925498 & 6,072724363 & 1,541195421 & 0,39373159 \\
\hline CP1/0359 M & 19,60456667 & & & & \\
\hline CP1/0385 T & 16,3089 & 31,27327309 & 5,202013948 & 6,011762637 & 1,63271248 \\
\hline CP1/0385 M & 21,20546667 & & & & \\
\hline CP3/0035 T & 25,37906667 & 0,007991775 & 0,048092556 & 0,166174879 & $-1,6336196$ \\
\hline CP3/0035 M & 18,5104 & & & & \\
\hline CP1/0348 T & 23,34153333 & 15,52069106 & 3,298003267 & 4,70608723 & 1,40983024 \\
\hline CP1/0348 M & 27,24166667 & & & & \\
\hline CP3/0019 T & 24,22775 & 4,506651513 & 100,7446826 & 0,044733393 & $-2,8281451$ \\
\hline CP3/0019 M & 26,36906667 & & & & \\
\hline CP3/0096 T & 30,92935 & 0,143364425 & 3,620018644 & 0,039603228 & $-2,9390211$ \\
\hline
\end{tabular}




\begin{tabular}{|c|c|c|c|c|c|}
\hline CP3/0096 M & 28,16676667 & & & & \\
\hline CP3/0199 T & 26,31246667 & 4,685491721 & 0,316176179 & 14,81924328 & 2,4539381 \\
\hline СР3/0199 M & 28,50913333 & & & & \\
\hline CP3/0249 T & 21,82483333 & 116,6767948 & 58,59027365 & 1,991402113 & 0,62700825 \\
\hline CP3/0249 M & 28,59403333 & & & & \\
\hline CP4/0016 T & 18,42475 & 31,70462347 & 3,746524325 & 8,462409615 & 1,9439378 \\
\hline CP4/0016 M & 23,3408 & & & & \\
\hline CP3/0377 T & 19,2991 & 91,76809785 & 1,389637673 & 66,03742804 & 3,81410413 \\
\hline CP3/0377 M & 25,72675 & & & & \\
\hline CP4/0024 T & 22,5073 & 0,316585458 & 1,358623738 & 0,233019231 & $-1,3258857$ \\
\hline CP4/0024 M & 20,87145 & & & & \\
\hline CP3/0390 T & 19,9221 & 20,90414689 & 53,33253591 & 0,391958615 & $-0,8525292$ \\
\hline CP3/0390 M & 24,24575 & & & & \\
\hline CP3/0433 T & 19,28545 & 315,4972714 & 24,31372205 & 12,97609929 & 2,33304249 \\
\hline CP3/0433 M & 27,46945 & & & & \\
\hline CP2/0096 T & 17,30843333 & 287,2376587 & 11,84540688 & 24,24886386 & 2,90217923 \\
\hline CP2/0096 M & 25,35896667 & & & & \\
\hline CP3/0018 T & 21,11096667 & 5,090568429 & 0,162460935 & 31,33410764 & 3,13550762 \\
\hline CP3/0018 M & 23,42556667 & & & & \\
\hline CP3/0031 T & 19,5983 & 1,607620083 & 0,364913731 & 4,40547984 & 1,34974749 \\
\hline CP3/0031 M & 20,27353333 & & & & \\
\hline CP3/0102 T & 17,29516667 & 5,213237526 & 3,87963054 & 1,343745873 & 0,26894032 \\
\hline CP3/0102 M & 19,64363333 & & & & \\
\hline CP3/0105 T & 20,1625 & 126,6095074 & 75,47159615 & 1,67757824 & 0,47091338 \\
\hline CP3/0105 M & 27,0479 & & & & \\
\hline CP3/0125 T & 23,1459 & 0,99819701 & 0,158242378 & 6,308025864 & 1,67649933 \\
\hline CP3/0125 M & 23,14333333 & & & & \\
\hline CP3/0136 T & 16,6846 & 2385,632044 & 13959,92139 & 0,17089151 & $-1,6081436$ \\
\hline CP3/0136 M & 27,74596667 & & & & \\
\hline CP3/0153 T & 18,61526667 & 2,846038018 & 2,890353656 & 0,984667746 & $-0,0140641$ \\
\hline CP3/0153 M & 20,10286667 & & & & \\
\hline CP4/0001 T & 18,2558 & 13,93251248 & 78,7070387 & 0,177017364 & $-1,576086$ \\
\hline CP4/0001 M & 22,0024 & & & & \\
\hline CP3/0085 T & 21,8453 & 1,053110301 & 2,274575231 & 0,462992073 & $-0,7009255$ \\
\hline CP3/0085 M & 21,9189 & & & & \\
\hline CP3/0464 T & 22,2703 & 1,704427288 & 2,907042554 & 0,586309714 & $-0,4859832$ \\
\hline CP3/0464 M & 23,0287 & & & & \\
\hline CP3/0076 T & 20,72335 & 2094,266902 & 9,272314911 & 225,8623572 & 4,93342905 \\
\hline СР3/0076 M & 31,59945 & & & & \\
\hline CP3/0119 T & 21,76195 & 4,445545615 & 1,695508627 & 2,621953994 & 0,87739765 \\
\hline CP3/0119 M & 23,88385 & & & & \\
\hline CP3/0411 T & 20,4754 & 2,15748371 & 2,606473364 & 0,827740555 & $-0,1720857$ \\
\hline CP3/0411 M & 21,56905 & & & & \\
\hline
\end{tabular}


Tabela 3. Valores de quantificação relativa da expressão do gene $K R T 19$, tendo como referência o gene GAPDH.

\begin{tabular}{|c|c|c|c|c|c|}
\hline \multicolumn{6}{|c|}{ Gene KRT19 } \\
\hline \multicolumn{6}{|c|}{ LÍNGUA } \\
\hline Amostras & média Ct KRT19 & $\left(E_{\text {KRT19 }}\right)^{\Delta C t(M C-A T)}$ & $\left(E_{G A P D H}\right)^{\Delta C t(M C-A T)}$ & $\begin{array}{l}\text { Expressão } \\
\text { Relativa }\end{array}$ & $\log _{3}$ \\
\hline CP1/0021 T & 22,8538 & 1,065721947 & 0,601460827 & 1,771889206 & 0,520699 \\
\hline CP1/0021 M & 22,9463 & & & & \\
\hline CP1/0057 T & 22,27703333 & 2,019568062 & 0,843265109 & 2,394938485 & 0,7949643 \\
\hline CP1/0057 M & 23,29846667 & & & & \\
\hline CP1/0151 T & 28,9392 & 0,050754909 & 0,645342071 & 0,078648071 & $-2,314531$ \\
\hline CP1/0151 M & 24,60756667 & & & & \\
\hline CP1/0200 T & 22,76473333 & 4,576306541 & 2,747674988 & 1,665519598 & 0,46434684 \\
\hline CP1/0200 M & 24,9749 & & & & \\
\hline CP1/0262 T & 22,38596667 & 0,978175493 & 0,112033619 & 8,731088977 & 1,97238837 \\
\hline CP1/0262 M & 22,3539 & & & & \\
\hline CP2/1002 T & 31,18893333 & 0,008176005 & 2,457938915 & 0,003326366 & $-5,1937111$ \\
\hline CP2/1002 M & 24,20403333 & & & & \\
\hline СР3/0049 T & 27,06073333 & 38,08495637 & 215,2567079 & 0,176928082 & $-1,5765452$ \\
\hline CP3/0049 M & 32,35013333 & & & & \\
\hline СР3/0050 T & 27,26383333 & 2,737107049 & 3,669468752 & 0,74591371 & $-0,2668324$ \\
\hline CP3/0050 M & 28,72706667 & & & & \\
\hline CP3/0087 T & 29,30986667 & 0,073863975 & - & - & - \\
\hline CP3/0087 M & 25,5235 & & & & \\
\hline СР3/0118 T & 23,71126667 & 7,891090276 & 7,45370248 & 1,058680608 & 0,05190496 \\
\hline СР3/0118 M & 26,7132 & & & & \\
\hline \multicolumn{6}{|c|}{ SOALHO DE BOCA } \\
\hline Amostras & média Ct KRT19 & $\left(E_{K R T 19}\right)^{\Delta C t(M C-A T)}$ & $\left(E_{G A P D H}\right)^{\Delta C t(M C-A T)}$ & $\begin{array}{l}\text { Expressão } \\
\text { Relativa }\end{array}$ & $\log _{3}$ \\
\hline CP2/0168 T & 22,2151 & 13,43939011 & 1,126268173 & 11,93267326 & 2,25673817 \\
\hline CP2/0168 M & 25,9908 & & & & \\
\hline CP1/0089 T & 21,59445 & 23,18120185 & 41,01191545 & 0,565230899 & $-0,5193106$ \\
\hline CP1/0089 M & 26,16236667 & & & & \\
\hline CP1/0255 T & 26,99063333 & 16,92913647 & 2643,846948 & 0,006403221 & $-4,5975766$ \\
\hline CP1/0255 M & 31,1018 & & & & \\
\hline CP1/0240 T & 19,77796667 & 11,97325111 & 9,696469214 & 1,234805252 & 0,19198153 \\
\hline CP1/0240 M & 23,3858 & & & & \\
\hline СР3/0033 T & 19,5516 & 217,4302418 & 13,09461928 & 16,60454857 & 2,55747792 \\
\hline СР3/0033 M & 27,37256667 & & & & \\
\hline СР3/0120 T & 24,9576 & 2,978932574 & 0,319046573 & 9,33698345 & 2,03345917 \\
\hline CP3/0120 M & 26,54386667 & & & & \\
\hline CP1/0080 T & 27,2641 & 0,252298867 & 2,010601077 & 0,125484299 & $-1,8892695$ \\
\hline CP1/0080 M & 25,26283333 & & & & \\
\hline CP1/0191 T & 20,37713333 & 3,052390353 & 0,982402798 & 3,107066022 & 1,03191899 \\
\hline CP1/0191 M & 21,9988 & & & & \\
\hline CP1/0024 T & 17,8418 & 144,1732666 & 1,534462735 & 93,95683801 & 4,13506708 \\
\hline CP1/0024 M & 25,0657 & & & & \\
\hline CP1/0075 T & 21,42666667 & 3,326265105 & 1,038894395 & 3,201735539 & 1,05923903 \\
\hline
\end{tabular}




\begin{tabular}{|c|c|c|c|c|c|}
\hline CP1/0075 M & 23,1732 & & & & \\
\hline CP1/0083 T & 29,05123333 & 1,96879696 & 2,689897809 & 0,731922586 & $-0,2840679$ \\
\hline CP1/0083 M & 30,03566667 & & & & \\
\hline CP1/0384 T & 26,95543333 & 0,295367438 & 8,469331779 & 0,03487494 & $-3,0547508$ \\
\hline CP1/0384 M & 25,1832 & & & & \\
\hline CP1/0366 T & 33,08255 & 0,000790732 & 2,028202824 & 0,000389869 & $-7,1451057$ \\
\hline CP1/0366 M & 22,70296667 & & & & \\
\hline CP1/0370 T & 32,99876667 & 0,050772375 & 0,816297195 & 0,062198395 & $-2,5281222$ \\
\hline CP1/0370 M & 28,66763333 & & & & \\
\hline $\mathrm{CP} 2 / 0051 \mathrm{~T}$ & 23,6884 & 5,839274688 & 3,466633806 & 1,684422127 & 0,47461926 \\
\hline CP2/0051 M & 26,25273333 & & & & \\
\hline CP2/0122 T & 24,24233333 & 2,42034222 & 7,439440006 & 0,325339302 & $-1,0220955$ \\
\hline CP2/0122 M & 25,52683333 & & & & \\
\hline CP1/0258 T & 22,4993 & 109,8570194 & 19,22837346 & 5,713276768 & 1,5863583 \\
\hline CP1/0258 M & 29,32816667 & & & & \\
\hline CP3/0280 T & 22,42733333 & 1,53851576 & 8,937365007 & 0,172144224 & $-1,6014955$ \\
\hline CP3/0280 M & 23,0534 & & & & \\
\hline $\mathrm{CP} 1 / 0032 \mathrm{~T}$ & 21,26256667 & 7,865429462 & 12,09498213 & 0,650305174 & $-0,3916883$ \\
\hline CP1/0032 M & 24,25976667 & & & & \\
\hline CP1/0213 T & 30,1246 & 0,002925191 & 1,403927007 & 0,002083578 & $-5,6195154$ \\
\hline CP1/0213 M & 21,64603333 & & & & \\
\hline CP1/0233 T & 26,98806667 & 0,139627636 & 9,20999539 & 0,015160446 & $-3,8130517$ \\
\hline CP1/0233 M & 24,12703333 & & & & \\
\hline CP1/0055 T & 34,16105 & 0,088054141 & 0,0198624 & 4,43320748 & 1,35545849 \\
\hline CP1/0055 M & 30,63005 & & & & \\
\hline CP1/0363 T & 21,80326667 & 22,91186423 & 9,562836985 & 2,395927513 & 0,79534012 \\
\hline CP1/0363 M & 26,3542 & & & & \\
\hline CP1/0228 T & 31,23423333 & 0,014135418 & 3,642967314 & 0,003880193 & $-5,0535301$ \\
\hline CP1/0228 M & 25,04493333 & & & & \\
\hline \multicolumn{6}{|c|}{ LARINGE } \\
\hline Amostras & média Ct KRT19 & $\left(E_{\text {KRT19 }}\right)^{\Delta C t(M C-A T)}$ & $\left(E_{G A P D H}\right)^{\Delta C t(M C-A T)}$ & $\begin{array}{c}\text { Expressão } \\
\text { Relativa }\end{array}$ & $\log _{3}$ \\
\hline CP1/0056 T & 34,88455 & 0,020780282 & 1,081482364 & 0,019214629 & $-3,5973413$ \\
\hline CP1/0056 M & 29,2552 & & & & \\
\hline CP1/0357 T & 25,0348 & 0,115573036 & 0,512641384 & 0,225446169 & $-1,3559596$ \\
\hline CP1/0357 M & 21,899 & & & & \\
\hline CP1/0359 T & 27,54033333 & 0,009458197 & 6,072724363 & 0,001557488 & $-5,8844061$ \\
\hline CP1/0359 M & 20,76713333 & & & & \\
\hline CP1/0385 T & 21,20906667 & 1,497706642 & 5,202013948 & 0,287909002 & $-1,1333487$ \\
\hline CP1/0385 M & 21,79606667 & & & & \\
\hline CP3/0035 T & 28,31393333 & 0,006938486 & 0,048092556 & 0,144273588 & $-1,7622631$ \\
\hline CP3/0035 M & 21,09053333 & & & & \\
\hline CP1/0348 T & 29,3785 & 0,742329326 & 3,298003267 & 0,225084473 & $-1,3574211$ \\
\hline CP1/0348 M & 28,9455 & & & & \\
\hline CP3/0019 T & 30,4313 & 74,01606508 & 100,7446826 & 0,734689546 & $-0,2806334$ \\
\hline CP3/0019 M & 36,6863 & & & & \\
\hline СР3/0096 T & 32,52195 & 3,167040493 & 3,620018644 & 0,874868559 & $-0,1216823$ \\
\hline
\end{tabular}




\begin{tabular}{|c|c|c|c|c|c|}
\hline CP3/0096 M & 34,1972 & & & & \\
\hline СР3/0199 T & 32,5638 & 0,192092191 & 0,316176179 & 0,607547956 & $-0,4535942$ \\
\hline CP3/0199 M & 30,16633333 & & & & \\
\hline CР3/0249 T & 28,49143333 & 11,64871155 & 58,59027365 & 0,198816473 & $-1,470376$ \\
\hline СР3/0249 M & 32,05933333 & & & & \\
\hline CP4/0016 T & 21,28745 & 4,779173678 & 3,746524325 & 1,275628626 & 0,22158782 \\
\hline CP4/0016 M & 23,56065 & & & & \\
\hline CP3/0377 T & 23,40785 & 61,26973409 & 1,389637673 & 44,0904383 & 3,44638685 \\
\hline CР3/0377 M & 29,3882 & & & & \\
\hline $\mathrm{CP} 4 / 0024 \mathrm{~T}$ & 24,0689 & 13,47040702 & 1,358623738 & 9,914744338 & 2,0881097 \\
\hline CP4/0024 M & 27,84795 & & & & \\
\hline CP3/0390 T & 26,4082 & 2,48823085 & 53,33253591 & 0,046655026 & $-2,7898601$ \\
\hline СР3/0390 M & 27,7329 & & & & \\
\hline CP3/0433 T & 24,3185 & 1,20119761 & 24,31372205 & 0,049404102 & $-2,7377464$ \\
\hline CP3/0433 M & 24,5849 & & & & \\
\hline CP2/0096 T & 21,2896 & 353,6220532 & 11,84540688 & 29,8530947 & 3,09143503 \\
\hline CP2/0096 M & 29,81733333 & & & & \\
\hline CP3/0018 T & 36,76825 & 4,7663E-05 & 0,162460935 & 0,000293381 & $-7,4039206$ \\
\hline CP3/0018 M & 22,3069 & & & & \\
\hline CP3/0031 T & 32,2597 & 0,000536219 & 0,364913731 & 0,00146944 & $-5,9373759$ \\
\hline CP3/0031 M & 21,31566667 & & & & \\
\hline СР3/0102 T & 26,0504 & 0,014914176 & 3,87963054 & 0,003844226 & $-5,0620069$ \\
\hline CP3/0102 M & 19,93903333 & & & & \\
\hline CP3/0105 T & 25,78836667 & 5,868412176 & 75,47159615 & 0,077756566 & $-2,3249078$ \\
\hline CP3/0105 M & 28,35993333 & & & & \\
\hline CP3/0125 T & 32,2555 & 0,032037962 & 0,158242378 & 0,20246133 & $-1,4538399$ \\
\hline CР3/0125 M & 27,25526667 & & & & \\
\hline СР3/0136 T & 23,09716667 & 1959,096868 & 13959,92139 & 0,140337242 & $-1,787443$ \\
\hline CP3/0136 M & 34,1128 & & & & \\
\hline СР3/0153 T & 26,13603333 & 0,010943224 & 2,890353656 & 0,003786119 & $-5,0758705$ \\
\hline CР3/0153 M & 19,57476667 & & & & \\
\hline $\mathrm{CP} 4 / 0001 \mathrm{~T}$ & 19,87496667 & 27,54693965 & 78,7070387 & 0,349993344 & $-0,9556066$ \\
\hline CP4/0001 M & 24,69363333 & & & & \\
\hline CP3/0085 T & 23,25885 & 1,28867173 & 2,274575231 & 0,566554894 & $-0,5171809$ \\
\hline CP3/0085 M & 23,6274 & & & & \\
\hline CP3/0464 T & 21,3764 & 18,26640532 & 2,907042554 & 6,283501179 & 1,67295356 \\
\hline СР3/0464 M & 25,59805 & & & & \\
\hline СР3/0076 T & 22,99925 & 10,4749008 & 9,272314911 & 1,129696403 & 0,1110027 \\
\hline СР3/0076 M & 26,4128 & & & & \\
\hline CP3/0119 T & 26,30845 & 1,95182269 & 1,695508627 & 1,151172373 & 0,12814428 \\
\hline СР3/0119 M & 27,2803 & & & & \\
\hline CP3/0411 T & 26,43485 & 0,154287232 & 2,606473364 & 0,059193865 & $-2,5731893$ \\
\hline CP3/0411 M & 23,7189 & & & & \\
\hline
\end{tabular}


Tabela 4. Valores de quantificação relativa da expressão do gene $M S L N$, tendo como referência o gene GAPDH.

\begin{tabular}{|c|c|c|c|c|c|}
\hline \multicolumn{6}{|c|}{ Gene MSLN } \\
\hline \multicolumn{6}{|c|}{ LÍNGUA } \\
\hline Amostras & Média Ct MSLN & $\left(E_{M S L N}\right)^{\Delta C t(M C-A T)}$ & $\left(E_{G A P D H}\right)^{\Delta C t(M C-A T)}$ & $\begin{array}{c}\text { Expressão } \\
\text { Relativa }\end{array}$ & $\log _{3}$ \\
\hline CP1/0021 T & 29,64463333 & 0,543352805 & 0,601460827 & 0,903388518 & $-0,0924826$ \\
\hline CP1/0021 M & 28,7831 & & & & \\
\hline CP1/0057 T & 27,65476667 & 0,185198168 & 0,843265109 & 0,219620338 & $-1,3797906$ \\
\hline CP1/0057 M & 25,27306667 & & & & \\
\hline CP1/0151 T & 35,71375 & 0,019186168 & 0,645342071 & 0,02973023 & $-3,2000287$ \\
\hline CP1/0151 M & 30,1299 & & & & \\
\hline CP1/0200 T & 25,97203333 & 561,2919669 & 2,747674988 & 204,2788792 & 4,84200493 \\
\hline CP1/0200 M & 34,9126 & & & & \\
\hline CP1/0262 T & 31,3887 & 1,064841941 & 0,112033619 & 9,504664346 & 2,04966091 \\
\hline CP1/0262 M & 31,47743333 & & & & \\
\hline CP2/1002 T & 34,9552 & 0,28720499 & 2,457938915 & 0,116847896 & $-1,9541764$ \\
\hline CP2/1002 M & 33,1932 & & & & \\
\hline CP3/0049 T & 30,90035 & 11,55698848 & 215,2567079 & 0,05368933 & $-2,6620319$ \\
\hline CР3/0049 M & 34,3568 & & & & \\
\hline CP3/0050 T & 25,3378 & 875,6016845 & 3,669468752 & 238,6181062 & 4,98343633 \\
\hline CP3/0050 M & 34,9064 & & & & \\
\hline CP3/0087 T & 34,06575 & 0,653308046 & - & - & - \\
\hline CP3/0087 M & 33,4645 & & & & \\
\hline CP3/0118 T & 31,87153333 & 1,297989832 & 7,45370248 & 0,174140279 & $-1,5910018$ \\
\hline CP3/0118 M & 32,2399 & & & & \\
\hline \multicolumn{6}{|c|}{ SOALHO DE BOCA } \\
\hline Amostras & Média Ct MSLN & $\left(E_{M S L N}\right)^{\Delta C t(M C-A T)}$ & $\left(E_{\text {GAPDH }}\right)^{\Delta C t(M C-A T)}$ & $\begin{array}{l}\text { Expressão } \\
\text { Relativa }\end{array}$ & $\log _{3}$ \\
\hline CP2/0168 T & 33,70125 & 0,124320298 & 1,126268173 & 0,110382501 & $-2,0059885$ \\
\hline CP2/0168 M & 30,75663333 & & & & \\
\hline CP1/0089 T & 29,5653 & 6,068762751 & 41,01191545 & 0,147975599 & $-1,7392013$ \\
\hline CP1/0089 M & 32,112 & & & & \\
\hline CP1/0255 T & 30,82245 & - & 2643,846948 & - & - \\
\hline CP1/0255 M & $\mathrm{N} / \mathrm{A}$ & & & & \\
\hline CP1/0240 T & 26,4413 & 16,94698375 & 9,696469214 & 1,747747905 & 0,50821209 \\
\hline CP1/0240 M & 30,4384 & & & & \\
\hline CP3/0033 T & 23,99063333 & 1308,997187 & 13,09461928 & 99,96450899 & 4,19148344 \\
\hline СР3/0033 M & 34,12715 & & & & \\
\hline CP3/0120 T & 25,3974 & 156,0289696 & 0,319046573 & 489,0476273 & 5,63661989 \\
\hline CP3/0120 M & 32,52986667 & & & & \\
\hline CP1/0080 T & 24,11393333 & 1027,932721 & 2,010601077 & 511,2564264 & 5,67704489 \\
\hline CP1/0080 M & 33,90906667 & & & & \\
\hline CP1/0191 T & 22,67403333 & 1582,178223 & 0,982402798 & 1610,518849 & 6,72149015 \\
\hline CP1/0191 M & 33,07825 & & & & \\
\hline CP1/0024 T & 23,23996667 & 373,4963449 & 1,534462735 & 243,4052886 & 5,00151688 \\
\hline CP1/0024 M & 31,60523333 & & & & \\
\hline CP1/0075 T & 30,12506667 & 3,237713571 & 1,038894395 & 3,11649922 & 1,03467833 \\
\hline
\end{tabular}




\begin{tabular}{|c|c|c|c|c|c|}
\hline CP1/0075 M & 31,7844 & & & & \\
\hline CP1/0083 T & 32,215 & 0,5007695 & 2,689897809 & 0,186166738 & $-1,5302146$ \\
\hline CP1/0083 M & 31,2382 & & & & \\
\hline CP1/0384 T & 32,29925 & 2,656430194 & 8,469331779 & 0,313652867 & $-1,0553936$ \\
\hline CP1/0384 M & 33,6791 & & & & \\
\hline CP1/0366 T & 30,5028 & 0,019725441 & 2,028202824 & 0,009725576 & $-4,2171348$ \\
\hline CP1/0366 M & 24,9581 & & & & \\
\hline CP1/0370 T & 31,16423333 & - & 0,816297195 & - & - \\
\hline CP1/0370 M & $\mathrm{N} / \mathrm{A}$ & & & & \\
\hline CP2/0051 T & 30,08263333 & 1,090169473 & 3,466633806 & 0,314474944 & $-1,053011$ \\
\hline CP2/0051 M & 30,20456667 & & & & \\
\hline CP2/0122 T & 31,09825 & 19,72860773 & 7,439440006 & 2,65189419 & 0,88773281 \\
\hline CP2/0122 M & 35,31 & & & & \\
\hline CP1/0258 T & 26,292 & 117,1082109 & 19,22837346 & 6,090385707 & 1,6445396 \\
\hline CP1/0258 M & 33,0192 & & & & \\
\hline CP3/0280 T & 34,04275 & 1,436378344 & 8,937365007 & 0,160716088 & $-1,6640228$ \\
\hline СР3/0280 M & 34,5542 & & & & \\
\hline CP1/0032 T & 26,84713333 & 13,35804785 & 12,09498213 & 1,104428903 & 0,09041258 \\
\hline CP1/0032 M & 30,50813333 & & & & \\
\hline CP1/0213 T & 32,7947 & 0,007815471 & 1,403927007 & 0,005566864 & $-4,7249821$ \\
\hline CP1/0213 M & 25,94243333 & & & & \\
\hline CP1/0233 T & 22,93743333 & 88,33486997 & 9,20999539 & 9,591195894 & 2,05791034 \\
\hline CP1/0233 M & 29,2664 & & & & \\
\hline CP1/0055 T & 32,3971 & 3,286252786 & 0,0198624 & 165,4509394 & 4,65011612 \\
\hline CP1/0055 M & 34,07745 & & & & \\
\hline CP1/0363 T & 25,0831 & 76,0755998 & 9,562836985 & 7,955337932 & 1,88769338 \\
\hline CP1/0363 M & 31,20105 & & & & \\
\hline CP1/0228 T & 31,50253333 & 0,346963007 & 3,642967314 & 0,095241867 & $-2,140278$ \\
\hline CP1/0228 M & 30,0075 & & & & \\
\hline \multicolumn{6}{|c|}{ LARINGE } \\
\hline Amostras & Média Ct MSLN & $\left(E_{M S L N}\right)^{\Delta C t(M C-A T)}$ & $\left(E_{G A P D H}\right)^{\Delta C t(M C ~-~ A T) ~}$ & $\begin{array}{c}\text { Expressão } \\
\text { Relativa }\end{array}$ & $\log _{3}$ \\
\hline СР1/0056 T & $N / A$ & - & 1,081482364 & - & - \\
\hline CP1/0056 M & 33,96036667 & & & & \\
\hline CP1/0357 T & 27,34643333 & 0,436829173 & 0,512641384 & 0,852114532 & $-0,1456695$ \\
\hline CP1/0357 M & 26,1767 & & & & \\
\hline CP1/0359 T & 27,3002 & 0,551101806 & 6,072724363 & 0,090750341 & $-2,1842492$ \\
\hline CP1/0359 M & 26,45866667 & & & & \\
\hline CP1/0385 T & 23,7951 & 1,877231036 & 5,202013948 & 0,360866206 & $-0,9277595$ \\
\hline CP1/0385 M & 24,6846 & & & & \\
\hline CP3/0035 T & 30,933666667 & 0,151060033 & 0,048092556 & 3,141027365 & 1,04181425 \\
\hline CP3/0035 M & 28,2642 & & & & \\
\hline CP1/0348 T & 33,13385 & 6,283450747 & 3,298003267 & 1,905228782 & 0,58674211 \\
\hline CP1/0348 M & 35,72965 & & & & \\
\hline СР3/0019 T & 34,00993333 & - & 100,7446826 & - & - \\
\hline CP3/0019 M & N/A & & & & \\
\hline СР3/0096 T & 37,3852 & 0,083473745 & 3,620018644 & 0,023058927 & $-3,4313309$ \\
\hline
\end{tabular}




\begin{tabular}{|c|c|c|c|c|c|}
\hline СР3/0096 M & 33,878 & & & & \\
\hline СР3/0199 T & N/A & - & 0,316176179 & - & - \\
\hline СР3/0199 M & 35,876 & & & & \\
\hline СР3/0249 T & 30,43875 & 5,565755753 & 58,59027365 & 0,094994534 & $-2,1426448$ \\
\hline СР3/0249 M & 32,86325 & & & & \\
\hline $\mathrm{CP} 4 / 0016 \mathrm{~T}$ & 25,8388 & 0,168059708 & 3,746524325 & 0,044857498 & $-2,8256233$ \\
\hline CP4/0016 M & 23,31995 & & & & \\
\hline CP3/0377 T & 26,0326 & 7,790848549 & 1,389637673 & 5,606388413 & 1,56916753 \\
\hline CP3/0377 M & 28,9321 & & & & \\
\hline CP4/0024 T & 26,483 & 1,249771171 & 1,358623738 & 0,91988027 & $-0,0760157$ \\
\hline CP4/0024 M & 26,7979 & & & & \\
\hline СР3/0390 T & 26,2665 & 115,5310704 & 53,33253591 & 2,166239959 & 0,70360848 \\
\hline CP3/0390 M & 32,97455 & & & & \\
\hline CP3/0433 T & 29,30835 & 0,014878749 & 24,31372205 & 0,000611949 & $-6,7347346$ \\
\hline CP3/0433 M & 23,3654 & & & & \\
\hline CP2/0096 T & 23,98346667 & 94,29828808 & 11,84540688 & 7,96074707 & 1,88831207 \\
\hline CP2/0096 M & 30,4047 & & & & \\
\hline СР3/0018 T & 36,08805 & 0,000362167 & 0,162460935 & 0,002229258 & $-5,5579996$ \\
\hline СР3/0018 M & 24,89736667 & & & & \\
\hline СР3/0031 T & 28,19346667 & 0,330006659 & 0,364913731 & 0,904341579 & $-0,0915229$ \\
\hline СР3/0031 M & 26,62766667 & & & & \\
\hline СР3/0102 T & 24,18186667 & 0,990346804 & 3,87963054 & 0,255268329 & $-1,2428771$ \\
\hline CP3/0102 M & 24,16816667 & & & & \\
\hline СР3/0105 T & 28,9699 & 11,18783331 & 75,47159615 & 0,148238992 & $-1,7375825$ \\
\hline СР3/0105 M & 32,3805 & & & & \\
\hline СР3/0125 T & 32,4068 & 0,35676153 & 0,158242378 & 2,254525845 & 0,73996959 \\
\hline СР3/0125 M & 30,9511 & & & & \\
\hline СР3/0136 T & 28,08856667 & 285,5443746 & 13959,92139 & 0,020454583 & $-3,5404194$ \\
\hline CP3/0136 M & 36,0746 & & & & \\
\hline СР3/0153 T & 33,2995 & 0,000722514 & 2,890353656 & 0,000249974 & $-7,5496637$ \\
\hline СР3/0153 M & 23,08423333 & & & & \\
\hline $\mathrm{CP} 4 / 0001 \mathrm{~T}$ & 29,5908 & 0,222116678 & 78,7070387 & 0,002822069 & $-5,3433637$ \\
\hline CP4/0001 M & 27,46583333 & & & & \\
\hline СР3/0085 T & 31,4336 & 0,006433693 & 2,274575231 & 0,002828525 & $-5,3412836$ \\
\hline СР3/0085 M & 24,30655 & & & & \\
\hline $\mathrm{CP} 3 / 0464 \mathrm{~T}$ & 29,2978 & 1,132631284 & 2,907042554 & 0,389616341 & $-0,8579849$ \\
\hline CP3/0464 M & 29,4737 & & & & \\
\hline СР3/0076 T & 25,3137 & 3,747100643 & 9,272314911 & 0,40411706 & $-0,8247229$ \\
\hline СР3/0076 M & 27,1794 & & & & \\
\hline СР3/0119 T & 27,5862 & 7,507095999 & 1,695508627 & 4,427636569 & 1,35431394 \\
\hline СР3/0119 M & 30,4333 & & & & \\
\hline СР3/0411 T & 24,86915 & 2,089719526 & 2,606473364 & 0,801742137 & $-0,201134$ \\
\hline CP3/0411 M & 25,9101 & & & & \\
\hline
\end{tabular}


Tabela 5. Valores de quantificação relativa da expressão do gene $K L K 8$, tendo como referência o gene GAPDH.

\begin{tabular}{|c|c|c|c|c|c|}
\hline \multicolumn{6}{|c|}{ Gene $K L K 8$} \\
\hline \multicolumn{6}{|c|}{ LÍNGUA } \\
\hline Amostras & média Ct KLK8 & $\left(\mathrm{E}_{\mathrm{KLK}}\right)_{\mathrm{AT})}^{\Delta \mathrm{Ct}(\mathrm{MC}-}$ & $\left(E_{G A P D H}\right)^{\Delta C t(M C-A T)}$ & $\begin{array}{l}\text { Expressão } \\
\text { Relativa }\end{array}$ & $\log _{3}$ \\
\hline CP1/0021 T & 26,4023 & 15,8865432 & 0,601460827 & 26,41326331 & 2,98000151 \\
\hline CP1/0021 M & 30,39203333 & & & & \\
\hline CP1/0057 T & 27,6336 & 0,590271258 & 0,843265109 & 0,699983021 & $-0,3246816$ \\
\hline CP1/0057 M & 26,87305 & & & & \\
\hline CP1/0151 T & 33,76876667 & 0,012412464 & 0,645342071 & 0,01923393 & $-3,5964275$ \\
\hline CP1/0151 M & 27,4367 & & & & \\
\hline CP1/0200 T & 28,3187 & 3,304808479 & 2,747674988 & 1,202765426 & 0,16805149 \\
\hline CP1/0200 M & 30,04326667 & & & & \\
\hline CP1/0262 T & 28,20633333 & 0,103629022 & 0,112033619 & 0,924981475 & $-0,0709819$ \\
\hline CP1/0262 M & 24,93583333 & & & & \\
\hline CP2/1002 T & 34,781 & 0,00443905 & 2,457938915 & 0,001806005 & $-5,7496517$ \\
\hline CP2/1002 M & 26,96546667 & & & & \\
\hline СР3/0049 T & 30,29666667 & 64,33729312 & 215,2567079 & 0,298886356 & $-1,0992885$ \\
\hline CP3/0049 M & 36,30425 & & & & \\
\hline CP3/0050 T & 31,27876667 & 0,048826223 & 3,669468752 & 0,013306074 & $-3,9318099$ \\
\hline CP3/0050 M & 26,92256667 & & & & \\
\hline CP3/0087 T & 32,30406667 & 0,013478465 & - & - & - \\
\hline CP3/0087 M & 26,09086667 & & & & \\
\hline СР3/0118 T & 26,6656 & 0,554003374 & 7,45370248 & 0,074325931 & $-2,3659806$ \\
\hline CP3/0118 M & 25,81356667 & & & & \\
\hline \multicolumn{6}{|c|}{ SOALHO DE BOCA } \\
\hline Amostras & média Ct KLK8 & $\left(E_{K L K 8}\right)^{\Delta C t(M C ~-~ A T) ~}$ & $\left(\mathrm{E}_{\mathrm{GAPDH}}\right)^{\Delta \mathrm{Ct}(\mathrm{MC}-\mathrm{AT})}$ & $\begin{array}{l}\text { Expressão } \\
\text { Relativa }\end{array}$ & $\log _{3}$ \\
\hline CP2/0168 T & 25,6993 & 3,248409096 & 1,126268173 & 2,884223469 & 0,96417609 \\
\hline CP2/0168 M & 27,39903333 & & & & \\
\hline CP1/0089 T & 26,51813333 & 16,91072569 & 41,01191545 & 0,412336891 & $-0,8063942$ \\
\hline CP1/0089 M & 30,598 & & & & \\
\hline CP1/0255 T & 24,47493333 & 3316,203134 & 2643,846948 & 1,254309799 & 0,20624697 \\
\hline CP1/0255 M & 36,17025 & & & & \\
\hline CP1/0240 T & 26,75703333 & 103,9803183 & 9,696469214 & 10,72352379 & 2,15948778 \\
\hline CP1/0240 M & 33,4572 & & & & \\
\hline CP3/0033 T & 26,0059 & 39,93273553 & 13,09461928 & 3,049553002 & 1,01491221 \\
\hline CP3/0033 M & 31,3254 & & & & \\
\hline CP3/0120 T & 31,56356667 & 2,113132649 & 0,319046573 & 6,623273298 & 1,72088891 \\
\hline CP3/0120 M & 32,64295 & & & & \\
\hline CP1/0080 T & 24,44043333 & 2,511588306 & 2,010601077 & 1,249172864 & 0,2025115 \\
\hline CP1/0080 M & 25,76903333 & & & & \\
\hline CP1/0191 T & 26,3547 & 1,109800225 & 0,982402798 & 1,129679422 & 0,11098901 \\
\hline CP1/0191 M & 26,505 & & & & \\
\hline CP1/0024 T & 26,5269 & 8,355927645 & 1,534462735 & 5,445507052 & 1,54266513 \\
\hline CP1/0024 M & 29,5897 & & & & \\
\hline CP1/0075 T & 28,6509 & 0,364578149 & 1,038894395 & 0,350928978 & $-0,9531765$ \\
\hline
\end{tabular}




\begin{tabular}{|c|c|c|c|c|c|}
\hline CP1/0075 M & 27,1952 & & & & \\
\hline CP1/0083 T & 28,6321 & 3,917138122 & 2,689897809 & 1,456240497 & 0,3421208 \\
\hline CP1/0083 M & 30,6019 & & & & \\
\hline CP1/0384 T & 25,3184 & 18,31897232 & 8,469331779 & 2,162977293 & 0,7022365 \\
\hline CP1/0384 M & 29,51366667 & & & & \\
\hline CP1/0366 T & 26,5348 & 5,127302442 & 2,028202824 & 2,528002812 & 0,84418279 \\
\hline CP1/0366 M & 28,893 & & & & \\
\hline CP1/0370 T & 25,0799 & 381,7188621 & 0,816297195 & 467,6224105 & 5,59584234 \\
\hline CP1/0370 M & 33,65626667 & & & & \\
\hline CP2/0051 T & 24,18666667 & 7,84750114 & 3,466633806 & 2,26372371 & 0,74367557 \\
\hline CP2/0051 M & 27,1589 & & & & \\
\hline CP2/0122 T & 24,6387 & 101,3756017 & 7,439440006 & 13,62677857 & 2,37757842 \\
\hline CP2/0122 M & 31,30226667 & & & & \\
\hline CP1/0258 T & 27,25266667 & 54,62539872 & 19,22837346 & 2,840874649 & 0,95039168 \\
\hline CP1/0258 M & 33,02416667 & & & & \\
\hline CP3/0280 T & 28,6782 & 0,535478294 & 8,937365007 & 0,05991456 & $-2,5621739$ \\
\hline CP3/0280 M & 27,7771 & & & & \\
\hline CP1/0032 T & 26,02296667 & 2,952424158 & 12,09498213 & 0,244103226 & $-1,2835867$ \\
\hline CP1/0032 M & 27,58486667 & & & & \\
\hline CP1/0213 T & 23,45013333 & 57,48047186 & 1,403927007 & 40,94263561 & 3,37896453 \\
\hline CP1/0213 M & 29,29513333 & & & & \\
\hline CP1/0233 T & 33,5638 & 0,015504527 & 9,20999539 & 0,001683446 & $-5,8136184$ \\
\hline CP1/0233 M & 27,55263333 & & & & \\
\hline CP1/0055 T & 34,30733333 & 0,262341266 & 0,0198624 & 13,20793371 & 2,3491615 \\
\hline CP1/0055 M & 32,37685 & & & & \\
\hline CP1/0363 T & 25,12213333 & 35,2243212 & 9,562836985 & 3,683459339 & 1,18681755 \\
\hline CP1/0363 M & 30,26063333 & & & & \\
\hline CP1/0228 T & 24,807 & 9,429840268 & 3,642967314 & 2,588505318 & 0,86571088 \\
\hline CP1/0228 M & 28,04423333 & & & & \\
\hline \multicolumn{6}{|c|}{ LARINGE } \\
\hline Amostras & média Ct KLK8 & $\left(E_{K L K}\right)^{\Delta C t(M C ~-~ A T) ~}$ & $\left(E_{G A P D H}\right)^{\Delta C t(M C-A T)}$ & $\begin{array}{l}\text { Expressão } \\
\text { Relativa }\end{array}$ & $\log _{3}$ \\
\hline CP1/0056 T & 36,72915 & 0,021307424 & 1,081482364 & 0,019702054 & $-3,5745389$ \\
\hline CP1/0056 M & 31,17665 & & & & \\
\hline CP1/0357 T & 28,427 & 0,210717959 & 0,512641384 & 0,411043599 & $-0,8092536$ \\
\hline CP1/0357 M & 26,18038519 & & & & \\
\hline CP1/0359 T & 15,0674 & 1528,145996 & 6,072724363 & 251,6409283 & 5,03180534 \\
\hline CP1/0359 M & 25,64496667 & & & & \\
\hline CP1/0385 T & 24,34503333 & 24,48738253 & 5,202013948 & 4,707288903 & 1,41006263 \\
\hline CP1/0385 M & 28,959 & & & & \\
\hline CP3/0035 T & 36,11835 & 0,00103085 & 0,048092556 & 0,021434708 & $-3,4978161$ \\
\hline CP3/0035 M & 26,1964 & & & & \\
\hline CP1/0348 T & 31,50695 & 2,678174566 & 3,298003267 & 0,812059403 & $-0,1894952$ \\
\hline CP1/0348 M & 32,9282 & & & & \\
\hline CP3/0019 T & 31,30636667 & 57,51767016 & 100,7446826 & 0,570925122 & $-0,5101866$ \\
\hline CP3/0019 M & 37,1523 & & & & \\
\hline СР3/0096 T & 31.60955 & - & 3.620018644 & - & - \\
\hline
\end{tabular}




\begin{tabular}{|c|c|c|c|c|c|}
\hline СР3/0096 M & N/A & & & & \\
\hline СР3/0199 T & 34,40625 & 0,234011283 & 0,316176179 & 0,740129392 & $-0,2739185$ \\
\hline СР3/0199 M & 32,3109 & & & & \\
\hline CP3/0249 T & 32,73895 & 2,882092555 & 58,59027365 & 0,049190631 & $-2,741688$ \\
\hline СР3/0249 M & 34,26606667 & & & & \\
\hline $\mathrm{CP} 4 / 0016 \mathrm{~T}$ & 26,4029 & 3,09127071 & 3,746524325 & 0,825103601 & $-0,1749901$ \\
\hline CP4/0016 M & 28,0311 & & & & \\
\hline CP3/0377 T & 27,4933 & 46,62558754 & 1,389637673 & 33,55233413 & 3,19776728 \\
\hline CP3/0377 M & 33,03635 & & & & \\
\hline CP4/0024 T & 25,38035 & 1,921123146 & 1,358623738 & 1,414021477 & 0,31534124 \\
\hline CP4/0024 M & 26,3223 & & & & \\
\hline СР3/0390 T & 25,81205 & 15,61055581 & 53,33253591 & 0,292702298 & $-1,1183192$ \\
\hline CP3/0390 M & 29,7765 & & & & \\
\hline СР3/0433 T & 24,9333 & 67,24709309 & 24,31372205 & 2,765808252 & 0,92601632 \\
\hline СР3/0433 M & 31,0047 & & & & \\
\hline CP2/0096 T & 24,10673333 & 562,5873617 & 11,84540688 & 47,49413571 & 3,51407524 \\
\hline CP2/0096 M & 33,24266667 & & & & \\
\hline СР3/0018 T & 30,89663333 & 0,483314215 & 0,162460935 & 2,974956502 & 0,99236958 \\
\hline СР3/0018 M & 29,84766667 & & & & \\
\hline СР3/0031 T & 26,132 & 22,80692437 & 0,364913731 & 62,49949635 & 3,76398347 \\
\hline CP3/0031 M & 30,6434 & & & & \\
\hline СР3/0102 T & 27,7922 & 0,80770479 & 3,87963054 & 0,208191162 & $-1,4284371$ \\
\hline СР3/0102 M & 27,4841 & & & & \\
\hline СР3/0105 T & 26,16066667 & 70,18544639 & 75,47159615 & 0,929958421 & $-0,0660974$ \\
\hline СР3/0105 M & 32,29376667 & & & & \\
\hline СР3/0125 T & 34,0206 & 0,495343079 & 0,158242378 & 3,130280818 & 1,03869466 \\
\hline CP3/0125 M & 33,0071 & & & & \\
\hline СР3/0136 T & 23,18926667 & 4944,755027 & 13959,92139 & 0,354210807 & $-0,9447037$ \\
\hline CP3/0136 M & 35,46095 & & & & \\
\hline СР3/0153 T & 25,75616667 & 6,79716589 & 2,890353656 & 2,351672736 & 0,77837003 \\
\hline СР3/0153 M & 28,5211 & & & & \\
\hline $\mathrm{CP} 4 / 0001 \mathrm{~T}$ & 24,23223333 & 32,99708479 & 78,7070387 & 0,419239313 & $-0,7912831$ \\
\hline CP4/0001 M & 29,2765 & & & & \\
\hline СР3/0085 T & 26,7048 & 0,258601043 & 2,274575231 & 0,113692016 & $-1,9790987$ \\
\hline СР3/0085 M & 24,7536 & & & & \\
\hline $\mathrm{CP} 3 / 0464 \mathrm{~T}$ & 28,32465 & 1,597316275 & 2,907042554 & 0,549464359 & $-0,5450616$ \\
\hline CP3/0464 M & 29,0003 & & & & \\
\hline СР3/0076 T & 31,44245 & 21,05440208 & 9,272314911 & 2,270673751 & 0,74646588 \\
\hline СР3/0076 M & 35,8385 & & & & \\
\hline СР3/0119 T & 26,08325 & 5,060394993 & 1,695508627 & 2,984588172 & 0,9953118 \\
\hline СР3/0119 M & 28,4225 & & & & \\
\hline СР3/0411 T & 25,5456 & 5,360063157 & 2,606473364 & 2,056442713 & 0,65626214 \\
\hline CP3/0411 M & 27,96785 & & & & \\
\hline
\end{tabular}


Anexo 2 
Tabela 1. Sessenta tags mais discriminativas com aumento de expressão em laringe $\mathrm{N}+$ versus laringe No, segundo Silveira et al., (2008). São apresentadas as frequências absolutas e normalizadas de cada tag nas bibliotecas de tumor e tecido normal, Unigene ID e símbolo do gene de acordo com a base de dados SAGEmap. A: biblioteca de laringe N+, NA: biblioteca de laringe NO, N: biblioteca de tecido normal.

\begin{tabular}{|c|c|c|c|c|c|c|c|c|}
\hline \multirow[b]{2}{*}{ Tag } & \multicolumn{3}{|c|}{ Frequência Absoluta } & \multicolumn{3}{|c|}{ Frequência Normalizada } & \multicolumn{2}{|c|}{ Anotação SAGEmap } \\
\hline & A & NA & $\mathbf{N}$ & A & NA & A / NA & Unigene ID & Símbolo do gene \\
\hline GTCTCTTGGG & 72 & 1 & 1 & 72 & 0,47 & 151,8 & 594095 & CMIP \\
\hline ATATTCTTTG & 154 & 7 & 4 & 154 & 3,32 & 46,4 & 515947 & NBPF10 \\
\hline ATAATCTTTG & 15 & 1 & 0 & 15 & 0,47 & 31,6 & \multicolumn{2}{|c|}{$\left[{ }^{*}\right.$ TAG NOT FOUNDED IN MAP *] } \\
\hline CCTAGCTGGT & 14 & 1 & 0 & 14 & 0,47 & 29,5 & \multicolumn{2}{|c|}{$\left[{ }^{*}\right.$ TAG NOT FOUNDED IN MAP *] } \\
\hline CACCTAATGG & 67 & 5 & 1 & 67 & 2,37 & 28,2 & \multicolumn{2}{|c|}{ [* TAG NOT FOUNDED IN MAP *] } \\
\hline GACTCTTCAG & 24 & 2 & 1 & 24 & 0,95 & 25,3 & 534293 & SERPINA3 \\
\hline GACCACCTTT & 12 & 1 & 2 & 12 & 0,47 & 25,3 & 389137 & MFAP2 \\
\hline GGTGGTGTCT & 34 & 3 & 19 & 34 & 1,42 & 23,9 & 2704 & GPX2 \\
\hline TGGGTTAATA & 11 & 1 & 0 & 11 & 0,47 & 23,2 & \multicolumn{2}{|c|}{ [* TAG NOT FOUNDED IN MAP *] } \\
\hline GCATAAATAG & 11 & 1 & 2 & 11 & 0,47 & 23,2 & 381123 & RPL21 \\
\hline ССАСТАСАСТ & 11 & 1 & 11 & 11 & 0,47 & 23,2 & 478275 & TNFSF10 \\
\hline GCATTAATAG & 10 & 1 & 1 & 10 & 0,47 & 21,1 & \multicolumn{2}{|c|}{ [ ${ }^{*}$ TAG NOT FOUNDED IN MAP *] } \\
\hline GCTTTCTCAC & 48 & 5 & 48 & 48 & 2,37 & 20,2 & 546269 & RPL10A \\
\hline GATTTTATAA & 9 & 1 & 0 & 9 & 0,47 & 19,0 & 659345 & \\
\hline GACATCAAGT & 9 & 1 & 55 & 9 & 0,47 & 19,0 & 654568 & KRT19 \\
\hline ATGTGAAGAA & 8 & 1 & 3 & 8 & 0,47 & 16,9 & 13662 & TMEM109 \\
\hline GGCACAATCA & 8 & 1 & 3 & 8 & 0,47 & 16,9 & 464416 & USP14 \\
\hline CTGGGTTAAA & 8 & 1 & 4 & 8 & 0,47 & 16,9 & \multicolumn{2}{|c|}{ [* TAG NOT FOUNDED IN MAP *] } \\
\hline GGAACTTTTA & 8 & 1 & 9 & 8 & 0,47 & 16,9 & 162016 & SULF2 \\
\hline TTGGGTCCTC & 7 & 1 & 0 & 7 & 0,47 & 14,8 & 484195 & LOC153222 \\
\hline TAGGGCATCT & 7 & 1 & 0 & 7 & 0,47 & 14,8 & 546298 & SUMO2 \\
\hline TGAGGTTCCC & 7 & 1 & 1 & 7 & 0,47 & 14,8 & 483444 & CXCL14 \\
\hline CCCATCGTGC & 7 & 1 & 3 & 7 & 0,47 & 14,8 & \multicolumn{2}{|c|}{ [* TAG NOT FOUNDED IN MAP *] } \\
\hline CAGAAATGAA & 7 & 1 & 3 & 7 & 0,47 & 14,8 & 81424 & SUMO1 \\
\hline CGGTTTCCAA & 7 & 1 & 3 & 7 & 0,47 & 14,8 & 496255 & PRKCZ \\
\hline TTAАTTCTTT & 7 & 1 & 3 & 7 & 0,47 & 14,8 & 77578 & USP9X \\
\hline AGCGAGAGAG & 7 & 1 & 4 & 7 & 0,47 & 14,8 & 449278 & BRD9 \\
\hline AAAGAACAGA & 7 & 1 & 5 & 7 & 0,47 & 14,8 & 636798 & \\
\hline
\end{tabular}




\begin{tabular}{|l|lll|lll|ll|} 
AAAGTCTAGA & 20 & 3 & 13 & 20 & 1,42 & 14,1 & 523852 & CCND1 \\
CCCCCTGCAG & 18 & 3 & 2 & 18 & 1,42 & 12,6 & 408488 & MSLN \\
GACTCCAAAA & 6 & 1 & 0 & 6 & 0,47 & 12,6 & 595011 & \\
CGCCCTTTCC & 6 & 1 & 0 & 6 & 0,47 & 12,6 & 483444 & CXCL14 \\
GCCACAGTAC & 6 & 1 & 0 & 6 & 0,47 & 12,6 & 55044 & DKFZP586H2123 \\
TTGGAGACTC & 6 & 1 & 0 & 6 & 0,47 & 12,6 & 546271 & PCBP2 \\
ACCCTGGGCA & 6 & 1 & 1 & 6 & 0,47 & 12,6 & 654792 & NADK \\
CGGCTGCCCA & 6 & 1 & 1 & 6 & 0,47 & 12,6 & 349470 & SNCG \\
TTGGGCCTCT & 6 & 1 & 1 & 6 & 0,47 & 12,6 & 632703 & RPL41 \\
GAGGGAGGTT & 6 & 1 & 2 & 6 & 0,47 & 12,6 & 169047 & NCAN \\
GGGAGGGCGC & 6 & 1 & 4 & 6 & 0,47 & 12,6 & 483444 & CXCL14 \\
GCCCCCTTCC & 6 & 1 & 4 & 6 & 0,47 & 12,6 & 212680 & TNFRSF18 \\
GCAAGAAAGT & 6 & 1 & 5 & 6 & 0,47 & 12,6 & 523443 & HBB \\
TTGTTATTGC & 6 & 1 & 6 & 6 & 0,47 & 12,6 & 631827 & ANXA7 \\
AGGCTCCTGG & 31 & 6 & 5 & 31 & 2,85 & 10,9 & 483444 & CXCL14 \\
TAGAAAGGCA & 10 & 2 & 21 & 10 & 0,95 & 10,5 & 503093 & ZFP36L2 \\
TGTCTGAGGG & 5 & 1 & 0 & 5 & 0,47 & 10,5 & 663639 & C6orf148 \\
CTGCCGAGCT & 5 & 1 & 0 & 5 & 0,47 & 10,5 & 93002 & UBE2C \\
TCCTGCTGGC & 5 & 1 & 0 & 5 & 0,47 & 10,5 & 645835 & PSAP \\
CCTTCCAATT & 5 & 1 & 1 & 5 & 0,47 & 10,5 & 659997 & FHAD1 \\
TAAGGAGTGA & 5 & 1 & 1 & 5 & 0,47 & 10,5 & {$\left[{ }^{*}\right.$ TAG NOT FOUNDED IN MAP * $]$} \\
CCTAGCTGGG & 5 & 1 & 1 & 5 & 0,47 & 10,5 & 356331 & PPIA \\
AGGAAGCTGC & 5 & 1 & 1 & 5 & 0,47 & 10,5 & 408018 & RPL36 \\
GAAAAATGGC & 5 & 1 & 1 & 5 & 0,47 & 10,5 & 654675 & CSNK2A1P \\
CGACGAGGAG & 5 & 1 & 1 & 5 & 0,47 & 10,5 & 9999 & EMP3 \\
TTGGGGGTTT & 5 & 1 & 1 & 5 & 0,47 & 10,5 & 524910 & FTH1 \\
CCTGGAATGA & 5 & 1 & 1 & 5 & 0,47 & 10,5 & 400876 & LOC388796 \\
GCTGTTGCAT & 5 & 1 & 1 & 5 & 0,47 & 10,5 & 498548 & RBM17 \\
CAATAAAATG & 5 & 1 & 1 & 5 & 0,47 & 10,5 & 222510 & DAZAP1 \\
CTAAGGCACT & 5 & 1 & 1 & 5 & 0,47 & 10,5 & 695299 & \\
CTCGAGCGGC & 18 & 4 & 1 & 18 & 1,90 & 9,5 & 476052 & SNRK \\
CCGTGCTCAT & 18 & 4 & 17 & 18 & 1,90 & 9,5 & 9857 & DCXR \\
GCATTTTGTG & 9 & 2 & 4 & 9 & 0,95 & 9,5 & 368527 & TOLLIP \\
\hline & & & & & & & & \\
\end{tabular}


Tabela 2. Sessenta tags mais discriminativas com redução de expressão em laringe $\mathrm{N}+$ versus laringe No, segundo Silveira et al., (2008). São apresentadas as frequências absolutas e normalizadas de cada tag nas bibliotecas de tumor e tecido normal, Unigene ID e símbolo do gene de acordo com a base de dados SAGEmap. A: biblioteca de laringe N+, NA: biblioteca de laringe NO, N: biblioteca de tecido normal.

\begin{tabular}{|c|c|c|c|c|c|c|c|c|}
\hline \multirow[b]{2}{*}{ Tag } & \multicolumn{3}{|c|}{ Frenquência Absoluta } & \multicolumn{3}{|c|}{ Frequência Normalizada } & \multicolumn{2}{|c|}{ Anotação SAGEmap } \\
\hline & A & NA & $\mathbf{N}$ & A & NA & NA / N & Unigene ID & Símbolo do gene \\
\hline TAAACCAAAT & 10 & 1063 & 0 & 10 & 504,32 & 50,4 & 382696 & \\
\hline СТСССССААА & 2 & 133 & 138 & 2 & 63,10 & 31,5 & 648398 & IGHA1 \\
\hline СТСССССААG & 4 & 221 & 341 & 4 & 104,85 & 26,2 & 648398 & IGHA1 \\
\hline GTGCCCGTGC & 2 & 94 & 63 & 2 & 44,60 & 22,3 & 524219 & TPI1 \\
\hline GTCTGTGCAG & 1 & 42 & 5 & 1 & 19,93 & 19,9 & 104570 & KLK8 \\
\hline GGAGTGTGCG & 1 & 41 & 16 & 1 & 19,45 & 19,5 & 4944 & C9orf58 \\
\hline TACATAATTA & 2 & 80 & 23 & 2 & 37,95 & 19,0 & 523789 & TncRNA \\
\hline GTGCGCCGGA & 1 & 39 & 2 & 1 & 18,50 & 18,5 & 2785 & KRT17 \\
\hline TACCTGCAAA & 1 & 39 & 46 & 1 & 18,50 & 18,5 & 647047 & NCF1 \\
\hline ACTGAGGAAA & 1 & 37 & 0 & 1 & 17,55 & 17,6 & 450230 & IGFBP3 \\
\hline GCTTTTTTTG & 1 & 37 & 63 & 1 & 17,55 & 17,6 & 654435 & AKR1A1 \\
\hline GGCTTCTAAC & 6 & 210 & 26 & 6 & 99,63 & 16,6 & 568518 & SPRR2E \\
\hline CCTGGGAAGT & 1 & 35 & 18 & 1 & 16,61 & 16,6 & 89603 & MUC1 \\
\hline GCCCTATGCG & 1 & 35 & 156 & 1 & 16,61 & 16,6 & 441280 & LYPD2 \\
\hline AGCTTCCACC & 1 & 32 & 3 & 1 & 15,18 & 15,2 & 490252 & SPRR2F \\
\hline GCGGAGGTGG & 1 & 30 & 66 & 1 & 14,23 & 14,2 & 648398 & IGHA1 \\
\hline СТTCTACTAA & 2 & 55 & 46 & 2 & 26,09 & 13,0 & 522401 & FAM129B \\
\hline TCCAGGGGCC & 1 & 27 & 40 & 1 & 12,81 & 12,8 & 170835 & UCHL5IP \\
\hline AGTCTGCTGG & 1 & 26 & 13 & 1 & 12,34 & 12,3 & 298713 & C10orf99 \\
\hline TTTCCTGCTC & 28 & 706 & 1845 & 28 & 334,95 & 12,0 & 139322 & SPRR3 \\
\hline TGGCTAAAAA & 1 & 23 & 11 & 1 & 10,91 & 10,9 & 535762 & SNHG8 \\
\hline GGGTTGGCTT & 1 & 22 & 21 & 1 & 10,44 & 10,4 & 523084 & SFTPA2B \\
\hline GAATAAATGT & 1 & 21 & 2 & 1 & 9,96 & 10,0 & 103934 & FKBP9 \\
\hline TAAGGCTTAA & 5 & 103 & 55 & 5 & 48,87 & 9,8 & 275464 & KLK10 \\
\hline AGAACCTTCC & 6 & 121 & 27 & 6 & 57,41 & 9,6 & 181244 & HLA-A \\
\hline TACCTGCAGA & 194 & 3907 & 3948 & 194 & 1853,60 & 9,6 & 416073 & S100A8 \\
\hline TATTGACAAC & 1 & 20 & 14 & 1 & 9,49 & 9,5 & 50382 & TJP2 \\
\hline GAAGCACAAG & 4 & 79 & 24 & 4 & 37,48 & 9,4 & 433845 & KRT6A \\
\hline
\end{tabular}




\begin{tabular}{|c|c|c|c|c|c|c|c|c|}
\hline GGGTCTGAGG & 3 & 57 & 218 & 3 & 27,04 & 9,0 & 657412 & \\
\hline СTTAAATCTG & 1 & 19 & 4 & 1 & 9,01 & 9,0 & 445203 & DNAJA1 \\
\hline AGTGCAGGGA & 2 & 37 & 9 & 2 & 17,55 & 8,8 & 449585 & IGL@ \\
\hline TAGAGATTTG & 4 & 72 & 24 & 4 & 34,16 & 8,5 & 181300 & SEL1L \\
\hline GTGCTGGTGC & 1 & 18 & 2 & 1 & 8,54 & 8,5 & 9613 & ANGPTL4 \\
\hline TGCCCCTGAA & 1 & 18 & 2 & 1 & 8,54 & 8,5 & 441975 & XAF1 \\
\hline ТААТТСТТСТ & 1 & 18 & 4 & 1 & 8,54 & 8,5 & 491494 & ССТЗ \\
\hline TGGCTTAAAT & 1 & 18 & 7 & 1 & 8,54 & 8,5 & 433213 & HIG2 \\
\hline TACTGCAGAA & 3 & 54 & 19 & 3 & 25,62 & 8,5 & 534221 & \\
\hline CTTGTAATCC & 3 & 52 & 3 & 3 & 24,67 & 8,2 & 493709 & NOL6 \\
\hline GAAATCCAAA & 2 & 34 & 0 & 2 & 16,13 & 8,1 & 500645 & ALDH18A1 \\
\hline TGGGTGAAAA & 1 & 17 & 1 & 1 & 8,07 & 8,1 & 359698 & DDC \\
\hline TGCCTGCAGA & 1 & 17 & 20 & 1 & 8,07 & 8,1 & 661757 & \\
\hline GTGGCTCACA & 4 & 66 & 14 & 4 & 31,31 & 7,8 & 433381 & C6orf89 \\
\hline TAAATAATTT & 2 & 33 & 3 & 2 & 15,66 & 7,8 & 1197 & HSPE1 \\
\hline CTGCAGGAAA & 1 & 16 & 3 & 1 & 7,59 & 7,6 & 689169 & \\
\hline CTTCTTGCCC & 1 & 16 & 3 & 1 & 7,59 & 7,6 & 449630 & HBA1 \\
\hline TGAGTGGTAG & 1 & 16 & 4 & 1 & 7,59 & 7,6 & 594444 & LMNA \\
\hline TTATGGATCT & 1 & 16 & 5 & 1 & 7,59 & 7,6 & 302963 & SPON2 \\
\hline CGGCTGAATT & 2 & 30 & 85 & 2 & 14,23 & 7,1 & 464071 & PGD \\
\hline GGCTCCTCGA & 1 & 15 & 5 & 1 & 7,12 & 7,1 & 370937 & TAPBP \\
\hline TGCTGCCTTT & 1 & 15 & 22 & 1 & 7,12 & 7,1 & 660027 & CAPNS2 \\
\hline TTGAATCCCC & 4 & 59 & 17 & 4 & 27,99 & 7,0 & 112341 & $\mathrm{PI3}$ \\
\hline GTGCTGGACC & 3 & 44 & 16 & 3 & 20,87 & 7,0 & 434081 & PSME2 \\
\hline GCCCACACAG & 5 & 73 & 36 & 5 & 34,63 & 6,9 & 1690 & FGFBP1 \\
\hline GTGCGGAGGA & 3 & 43 & 1 & 3 & 20,40 & 6,8 & 632144 & SAA1 \\
\hline GTGGCCACGG & 107 & 1515 & 3758 & 107 & 718,76 & 6,7 & 112405 & S100A9 \\
\hline TAGGTGTCTA & 2 & 28 & 4 & 2 & 13,28 & 6,6 & 374596 & TPT1 \\
\hline TTGCTCACAA & 2 & 28 & 13 & 2 & 13,28 & 6,6 & 572830 & \\
\hline CTGCTAAAAG & 1 & 14 & 32 & 1 & 6,64 & 6,6 & 518198 & CSTA \\
\hline TGTGCCAGTG & 1 & 14 & 104 & 1 & 6,64 & 6,6 & 331555 & SPINK5 \\
\hline TGTATGTAAA & 2 & 27 & 25 & 2 & 12,81 & 6,4 & 275464 & KLK10 \\
\hline GGCCCAGGCC & 3 & 40 & 216 & 3 & 18,98 & 6,3 & 531682 & ALDH3A1 \\
\hline
\end{tabular}


Tabela 3. Sessenta tags mais discriminativas com aumento de expressão em laringe $\mathrm{N}+$ versus laringe normal, segundo Silveira et al., (2008). São apresentadas as frequências absolutas e normalizadas de cada tag nas bibliotecas de tumor e tecido normal, Unigene ID e símbolo do gene de acordo com a base de dados SAGEmap. A: biblioteca de laringe N+, NA: biblioteca de laringe NO, N: biblioteca de tecido normal.

\begin{tabular}{|c|c|c|c|c|c|c|c|c|}
\hline \multirow[b]{2}{*}{ Tag } & \multicolumn{3}{|c|}{ Frequência Absoluta } & \multicolumn{3}{|c|}{ Frequencia Normalizada } & \multicolumn{2}{|c|}{ Anotação SAGEmap } \\
\hline & A & NA & $\mathbf{N}$ & A & $\mathbf{N}$ & A / N & Unigene ID & Símbolo do gene \\
\hline GTCTCTTGGG & 72 & 1 & 1 & 72 & 0,44 & 162,2 & 594095 & CMIP \\
\hline CACCTAATGG & 67 & 5 & 1 & 67 & 0,44 & 150,9 & {$\left[{ }^{\star}\right.$ TAG NOT $\mathrm{F}$} & EOUNDED IN MAP *] \\
\hline ATATTCTTTG & 154 & 7 & 4 & 154 & 1,78 & 86,7 & 515947 & NBPF10 \\
\hline GGTTGAAAAA & 36 & 0 & 1 & 36 & 0,44 & 81,1 & 446545 & \\
\hline GACTCTTCAG & 24 & 2 & 1 & 24 & 0,44 & 54,1 & 534293 & SERPINA3 \\
\hline CTCGAGCGGC & 18 & 4 & 1 & 18 & 0,44 & 40,6 & 476052 & SNRK \\
\hline TTCGGTTGGT & 17 & 6 & 1 & 17 & 0,44 & 38,3 & 172928 & COL1A1 \\
\hline GTCATAGCTG & 14 & 9 & 1 & 14 & 0,44 & 31,5 & 459790 & VPS13A \\
\hline TGGCCCCAGG & 13 & 15 & 1 & 13 & 0,44 & 29,3 & 110675 & APOC1 \\
\hline GATCTCTTGT & 12 & 0 & 1 & 12 & 0,44 & 27,0 & {$\left[{ }^{*}\right.$ TAG NOT $\mathrm{F}$} & [OUNDED IN MAP *] \\
\hline CTGGGTTATA & 12 & 3 & 1 & 12 & 0,44 & 27,0 & {$\left[{ }^{\star}\right.$ TAG NOT $\mathrm{F}$} & EOUNDED IN MAP *] \\
\hline СТССТTAAGA & 11 & 4 & 1 & 11 & 0,44 & 24,8 & 699303 & GOSR1 \\
\hline CCTTGACCAA & 11 & 16 & 1 & 11 & 0,44 & 24,8 & 369052 & SELT \\
\hline CCAGGGGAGA & 51 & 186 & 5 & 51 & 2,22 & 23,0 & 532634 & IFI27 \\
\hline GTTATAATAC & 20 & 7 & 2 & 20 & 0,89 & 22,5 & 510078 & SGK \\
\hline CAGCCTGGGG & 10 & 0 & 1 & 10 & 0,44 & 22,5 & 72026 & PRSS21 \\
\hline CCTAGACTGG & 10 & 0 & 1 & 10 & 0,44 & 22,5 & 522746 & CLDN2 \\
\hline GCATTAATAG & 10 & 1 & 1 & 10 & 0,44 & 22,5 & {$\left[{ }^{*}\right.$ TAG NOT $\mathrm{F}$} & [OUNDED IN MAP *] \\
\hline GATAATTCTT & 19 & 0 & 2 & 19 & 0,89 & 21,4 & {$\left[{ }^{*}\right.$ TAG NOT $\mathrm{F}$} & [OUNDED IN MAP *] \\
\hline СССССТGСАG & 18 & 3 & 2 & 18 & 0,89 & 20,3 & 408488 & MSLN \\
\hline CCTATCAGTA & 9 & 0 & 1 & 9 & 0,44 & 20,3 & 255462 & MSMB \\
\hline TTCGGGTGTG & 9 & 4 & 1 & 9 & 0,44 & 20,3 & 592049 & PLK1 \\
\hline GGATTGGCCT & 52 & 30 & 6 & 52 & 2,66 & 19,5 & 437594 & RPLP2 \\
\hline CAGGTTTCAT & 326 & 95 & 40 & 326 & 17,76 & 18,4 & 483444 & CXCL14 \\
\hline TGGAAATGAC & 40 & 28 & 5 & 40 & 2,22 & 18,0 & 172928 & COL1A1 \\
\hline ACСCTGCCAA & 16 & 16 & 2 & 16 & 0,89 & 18,0 & 193832 & GPATCH4 \\
\hline AATTTCCAGT & 8 & 0 & 1 & 8 & 0,44 & 18,0 & 98785 & FGFBP2 \\
\hline CCCATCGCCC & 8 & 2 & 1 & 8 & 0,44 & 18,0 & {$\left[{ }^{*}\right.$ TAG NOT $\mathrm{F}$} & EOUNDED IN MAP *] \\
\hline
\end{tabular}




\begin{tabular}{|l|lll|lll|ll|} 
CTGGGACTGA & 8 & 12 & 1 & 8 & 0,44 & 18,0 & 515255 & LSM4 \\
CCAATAAAGT & 31 & 0 & 4 & 31 & 1,78 & 17,5 & 529571 & RBP1 \\
TGCTGCCTGT & 28 & 91 & 4 & 28 & 1,78 & 15,8 & 118110 & BST2 \\
ATCAAAGGTT & 14 & 7 & 2 & 14 & 0,89 & 15,8 & 357004 & OLFML2A \\
GGAATGAGAA & 7 & 0 & 1 & 7 & 0,44 & 15,8 & 373550 & TGIF1 \\
TGAGGTTCCC & 7 & 1 & 1 & 7 & 0,44 & 15,8 & 483444 & CXCL14 \\
ATAAAGCTAC & 7 & 3 & 1 & 7 & 0,44 & 15,8 & 533543 & F8A1 \\
ATGTGAAGAG & 73 & 44 & 11 & 73 & 4,88 & 15,0 & 111779 & SPARC \\
GCAACTTAGA & 13 & 19 & 2 & 13 & 0,89 & 14,6 & 591484 & LAMC2 \\
CGCCGACGAT & 45 & 552 & 7 & 45 & 3,11 & 14,5 & 523847 & IFI6 \\
AGGCTCCTGG & 31 & 6 & 5 & 31 & 2,22 & 14,0 & 483444 & CXCL14 \\
GCCAGGTTGC & 12 & 0 & 2 & 12 & 0,89 & 13,5 & 374191 & LEPREL1 \\
GACCACCTTT & 12 & 1 & 2 & 12 & 0,89 & 13,5 & 389137 & MFAP2 \\
ACCAAAAACC & 12 & 5 & 2 & 12 & 0,89 & 13,5 & 172928 & COL1A1 \\
ACCCTGGGCA & 6 & 1 & 1 & 6 & 0,44 & 13,5 & 654792 & NADK \\
CGGCTGCCCA & 6 & 1 & 1 & 6 & 0,44 & 13,5 & 349470 & SNCG \\
TTGGGCCTCT & 6 & 1 & 1 & 6 & 0,44 & 13,5 & 632703 & RPL41 \\
AAAAATAAAA & 6 & 2 & 1 & 6 & 0,44 & 13,5 & 396358 & TMEM106B \\
TCAACAGCGT & 6 & 2 & 1 & 6 & 0,44 & 13,5 & 591054 & BID \\
GTCCTGGAGG & 6 & 5 & 1 & 6 & 0,44 & 13,5 & 476697 & \\
GCCCCCTGCT & 6 & 5 & 1 & 6 & 0,44 & 13,5 & {$\left[{ }^{*}\right.$ TAG NOT } & FOUNDED IN MAP *] \\
AGATTCAAAC & 6 & 7 & 1 & 6 & 0,44 & 13,5 & 108029 & SH3BGRL \\
TTTGTTGTAT & 6 & 9 & 1 & 6 & 0,44 & 13,5 & 584957 & TOR3A \\
CCATAATGTT & 6 & 10 & 1 & 6 & 0,44 & 13,5 & 170473 & PLEK2 \\
TTGAATTCCC & 17 & 8 & 3 & 17 & 1,33 & 12,8 & 269109 & SEMA3C \\
TTATGTTTAA & 17 & 17 & 3 & 17 & 1,33 & 12,8 & 406475 & LUM \\
GCATAAATAG & 11 & 1 & 2 & 11 & 0,89 & 12,4 & 381123 & RPL21 \\
TTTCTGTATG & 11 & 9 & 2 & 11 & 0,89 & 12,4 & 180877 & H3F3B \\
CCTTTGAACA & 20 & 7 & 4 & 20 & 1,78 & 11,3 & 444600 & BOLA2 \\
TCAGACTTTG & 10 & 5 & 2 & 10 & 0,89 & 11,3 & 656473 & DTL \\
AGCCTTGGTA & 5 & 0 & 1 & 5 & 0,44 & 11,3 & 533258 & CEL \\
TAATAAAAGG & 5 & 0 & 1 & 5 & 0,44 & 11,3 & 512675 & RPS8 \\
CCTTCCAATT & 5 & 1 & 1 & 5 & 0,44 & 11,3 & 659997 & FHAD1 \\
\hline & & & & & & & &
\end{tabular}


Tabela 4. Sessenta tags mais discriminativas com redução de expressão em laringe $\mathrm{N}+$ versus laringe normal, segundo Silveira et al., (2008). São apresentadas as frequências absolutas e normalizadas de cada tag nas bibliotecas de tumor e tecido normal, Unigene ID e símbolo do gene de acordo com a base de dados SAGEmap. A: biblioteca de laringe N+, NA: biblioteca de laringe NO, N: biblioteca de tecido normal.

\begin{tabular}{|c|c|c|c|c|c|c|c|c|}
\hline \multirow[b]{2}{*}{ Tag } & \multicolumn{3}{|c|}{ Frequência Absoluta } & \multicolumn{3}{|c|}{ Frequência Normalizada } & \multicolumn{2}{|c|}{ Anotação SAGEmap } \\
\hline & A & NA & $\mathbf{N}$ & A & $\mathbf{N}$ & N/A & Unigene ID & Símbolo do gene \\
\hline AAAGCGGGGC & 1 & 6 & 823 & 1 & 365,32 & 365,3 & 654550 & KRT13 \\
\hline GCCCTATGCG & 1 & 35 & 156 & 1 & 69,25 & 69,2 & 441280 & LYPD2 \\
\hline GGAGGTGAGA & 1 & 0 & 112 & 1 & 49,72 & 49,7 & 697198 & \\
\hline СТСТААСТТС & 1 & 0 & 110 & 1 & 48,83 & 48,8 & 408153 & PRR4 \\
\hline TGTGCCAGTG & 1 & 14 & 104 & 1 & 46,16 & 46,2 & 331555 & SPINK5 \\
\hline СТСССССАAG & 4 & 221 & 341 & 4 & 151,37 & 37,8 & 648398 & IGHA1 \\
\hline GGGTCTGAGG & 3 & 57 & 218 & 3 & 96,77 & 32,3 & 657412 & \\
\hline GGCCCAGGCC & 3 & 40 & 216 & 3 & 95,88 & 32,0 & 531682 & ALDH3A1 \\
\hline AAAATAAACC & 1 & 8 & 71 & 1 & 31,52 & 31,5 & 192233 & PPL \\
\hline СТСССССААА & 2 & 133 & 138 & 2 & 61,26 & 30,6 & 648398 & IGHA1 \\
\hline GCGGAGGTGG & 1 & 30 & 66 & 1 & 29,30 & 29,3 & 648398 & IGHA1 \\
\hline TTTCCTGCTC & 28 & 706 & 1845 & 28 & 818,97 & 29,2 & 139322 & SPRR3 \\
\hline TAATTTGCGT & 3 & 0 & 194 & 3 & 86,11 & 28,7 & 696241 & EMP1 \\
\hline CGTGGGGCTG & 1 & 1 & 63 & 1 & 27,96 & 28,0 & 298023 & AQP5 \\
\hline GCTTTTTTTG & 1 & 37 & 63 & 1 & 27,96 & 28,0 & 654435 & AKR1A1 \\
\hline GTGGGCCACG & 1 & 3 & 46 & 1 & 20,42 & 20,4 & 648398 & IGHA1 \\
\hline TACCTGCAAA & 1 & 39 & 46 & 1 & 20,42 & 20,4 & 647047 & NCF1 \\
\hline AGGGTGGTGA & 2 & 4 & 90 & 2 & 39,95 & 20,0 & 451636 & LOC342897 \\
\hline CGGGAGCGCT & 3 & 31 & 131 & 3 & 58,15 & 19,4 & 148590 & CNFN \\
\hline CGGCTGAATT & 2 & 30 & 85 & 2 & 37,73 & 18,9 & 464071 & PGD \\
\hline TCCAGGGGCC & 1 & 27 & 40 & 1 & 17,76 & 17,8 & 170835 & UCHL5IP \\
\hline ATGACAGATG & 1 & 3 & 37 & 1 & 16,42 & 16,4 & 654864 & HOP \\
\hline GTGGCCACGG & 107 & 1515 & 3758 & 107 & 1668,13 & 15,6 & 112405 & S100A9 \\
\hline GTAAAACCCG & 1 & 5 & 34 & 1 & 15,09 & 15,1 & 620532 & A2ML1 \\
\hline CTGCTAAAAG & 1 & 14 & 32 & 1 & 14,20 & 14,2 & 518198 & CSTA \\
\hline GTGCCCGTGC & 2 & 94 & 63 & 2 & 27,96 & 14,0 & 524219 & TPI1 \\
\hline GCTTTTCTGG & 1 & 3 & 30 & 1 & 13,32 & 13,3 & 139322 & SPRR3 \\
\hline TGTAAGGCAG & 1 & 5 & 28 & 1 & 12,43 & 12,4 & 331555 & SPINK5 \\
\hline
\end{tabular}




\begin{tabular}{|l|lll|lll|ll|} 
TGTGAAGCCT & 1 & 0 & 26 & 1 & 11,54 & 11,5 & 331555 & SPINK5 \\
AGAAAGATGT & 57 & 237 & 1337 & 57 & 593,48 & 10,4 & 494173 & ANXA1 \\
CTTCTACTAA & 2 & 55 & 46 & 2 & 20,42 & 10,2 & 522401 & FAM129B \\
CCCTACCCTG & 1 & 0 & 23 & 1 & 10,21 & 10,2 & 522555 & APOD \\
CTCACCGCCC & 1 & 6 & 22 & 1 & 9,77 & 9,8 & 405662 & CRABP2 \\
GTGGCACGTG & 1 & 8 & 22 & 1 & 9,77 & 9,8 & 437191 & PTRF \\
TGCTGCCTTT & 1 & 15 & 22 & 1 & 9,77 & 9,8 & 660027 & CAPNS2 \\
GCGGCCACGG & 1 & 2 & 21 & 1 & 9,32 & 9,3 & 517729 & MLC1 \\
TCAACGGTGT & 1 & 5 & 21 & 1 & 9,32 & 9,3 & 306242 & RANBP9 \\
TGGCGTACGG & 1 & 11 & 21 & 1 & 9,32 & 9,3 & 586701 & \\
GGGTTGGCTT & 1 & 22 & 21 & 1 & 9,32 & 9,3 & 523084 & SFTPA2B \\
CAACTAATTC & 2 & 5 & 41 & 2 & 18,20 & 9,1 & 436657 & CLU \\
TACCTGCAGA & 194 & 3907 & 3948 & 194 & 1752,47 & 9,0 & 416073 & S100A8 \\
GTACGTATTC & 10 & 50 & 200 & 10 & 88,78 & 8,9 & 676758 & \\
TTCCTCCACG & 1 & 2 & 20 & 1 & 8,88 & 8,9 & 436500 & DBNL \\
TACCTTGCAG & 1 & 4 & 20 & 1 & 8,88 & 8,9 & [* TAG NOT FOUNDED IN MAP *] \\
TGCCTGCAGA & 1 & 17 & 20 & 1 & 8,88 & 8,9 & 661757 & \\
AGGTCTGCCA & 1 & 3 & 19 & 1 & 8,43 & 8,4 & 567256 & AKR1C2 \\
ACTTTTTCAA & 10 & 125 & 187 & 10 & 83,01 & 8,3 & [* TAG NOT FOUNDED IN MAP *] \\
AGGATGTGGG & 2 & 12 & 37 & 2 & 16,42 & 8,2 & 435120 & KIF1C \\
ATGAGCTGAC & 23 & 98 & 414 & 23 & 183,77 & 8,0 & 695 & CSTB \\
ATCCCTTGCT & 1 & 3 & 18 & 1 & 7,99 & 8,0 & [* TAG NOT FOUNDED IN MAP *] \\
GGGCAGGCGT & 1 & 7 & 18 & 1 & 7,99 & 8,0 & 501629 & IER2 \\
CCTGGGAAGT & 1 & 35 & 18 & 1 & 7,99 & 8,0 & 89603 & MUC1 \\
CTGATGGCGA & 4 & 20 & 71 & 4 & 31,52 & 7,9 & 655453 & ZFAND1 \\
TGGTTGGTGG & 1 & 0 & 17 & 1 & 7,55 & 7,5 & 632215 & PLLP \\
ACTCGTATAT & 1 & 1 & 17 & 1 & 7,55 & 7,5 & 81134 & IL1RN \\
ACTCAGTAGC & 1 & 2 & 17 & 1 & 7,55 & 7,5 & 318894 & GPR126 \\
GGCCCATATG & 1 & 2 & 17 & 1 & 7,55 & 7,5 & 653859 & EHF \\
AGCCACCACG & 1 & 5 & 17 & 1 & 7,55 & 7,5 & 232054 & SLC47A1 \\
ACTGCCCGCT & 3 & 2 & 50 & 3 & 22,19 & 7,4 & 81071 & ECM1 \\
GGGCGGGTCC & 1 & 2 & 16 & 1 & 7,10 & 7,1 & 381282 & TYRO3 \\
GGAGTGTGCG & 1 & 41 & 16 & 1 & 7,10 & 7,1 & 4944 & C9orf58 \\
\hline & & & & & & & & \\
\hline
\end{tabular}


Tabela 5. Sessenta tags mais discriminativas com aumento de expressão em laringe No versus laringe normal, segundo Silveira et al., (2008). São apresentadas as frequências absolutas e normalizadas de cada tag nas bibliotecas de tumor e tecido normal, Unigene ID e símbolo do gene de acordo com a base de dados SAGEmap. A: biblioteca de laringe N+, NA: biblioteca de laringe NO, N: biblioteca de tecido normal.

\begin{tabular}{|c|c|c|c|c|c|c|c|c|}
\hline \multirow[b]{2}{*}{ Tag } & \multicolumn{3}{|c|}{ Frequência Absoluta } & \multicolumn{3}{|c|}{ Frequência Normalizada } & \multicolumn{2}{|c|}{ Anotação SAGEmap } \\
\hline & A & NA & $\mathbf{N}$ & NA & $\mathbf{N}$ & NA / N & Unigene ID & Símbolo do gene \\
\hline CGCCGACGAT & 45 & 552 & 7 & 261,89 & 3,11 & 84,3 & 523847 & IFI6 \\
\hline GTGCGGAGGA & 3 & 43 & 1 & 20,40 & 0,44 & 46,0 & 632144 & SAA1 \\
\hline ACCATTGGAT & 4 & 38 & 1 & 18,03 & 0,44 & 40,6 & 458414 & IFITM2 \\
\hline CCAGGGGAGA & 51 & 186 & 5 & 88,24 & 2,22 & 39,8 & 532634 & IFI27 \\
\hline TGCTGCCTGT & 28 & 91 & 4 & 43,17 & 1,78 & 24,3 & 118110 & BST2 \\
\hline GTGAAACTAA & 0 & 22 & 1 & 10,44 & 0,44 & 23,5 & 132660 & KIAA1467 \\
\hline CAGCTGGCCC & 4 & 43 & 2 & 20,40 & 0,89 & 23,0 & 654380 & KRT14 \\
\hline AATCTGCGCC & 9 & 85 & 4 & 40,33 & 1,78 & 22,7 & 458485 & ISG15 \\
\hline GTGCGCCGGA & 1 & 39 & 2 & 18,50 & 0,89 & 20,8 & 2785 & KRT17 \\
\hline CTTGTAATCC & 3 & 52 & 3 & 24,67 & 1,33 & 18,5 & 493709 & NOL6 \\
\hline TGGGTGAAAA & 1 & 17 & 1 & 8,07 & 0,44 & 18,2 & 359698 & DDC \\
\hline GATGTGCACG & 40 & 162 & 10 & 76,86 & 4,44 & 17,3 & 654380 & KRT14 \\
\hline CCTTGACCAA & 11 & 16 & 1 & 7,59 & 0,44 & 17,1 & 369052 & SELT \\
\hline TGGCCCCAGG & 13 & 15 & 1 & 7,12 & 0,44 & 16,0 & 110675 & APOC1 \\
\hline СTTCCTGCCT & 0 & 15 & 1 & 7,12 & 0,44 & 16,0 & \multicolumn{2}{|c|}{ [* TAG NOT FOUNDED IN MAP *] } \\
\hline CACTTCAAGG & 15 & 88 & 6 & 41,75 & 2,66 & 15,7 & 521903 & LY6E \\
\hline GAGCAGCGCC & 40 & 239 & 17 & 113,39 & 7,55 & 15,0 & 112408 & S100A7 \\
\hline GTACTAGTGT & 0 & 14 & 1 & 6,64 & 0,44 & 15,0 & 303649 & CCL2 \\
\hline ТСАТTTТССА & 0 & 14 & 1 & 6,64 & 0,44 & 15,0 & 540696 & SLC6A8 \\
\hline AGTGTGGAAG & 0 & 14 & 1 & 6,64 & 0,44 & 15,0 & 654380 & KRT14 \\
\hline AGCССТTCCT & 5 & 13 & 1 & 6,17 & 0,44 & 13,9 & 237856 & SLC15A3 \\
\hline AAAGCAGTTT & 5 & 26 & 2 & 12,34 & 0,89 & 13,9 & 114309 & APOL1 \\
\hline TCACAGTGCC & 4 & 26 & 2 & 12,34 & 0,89 & 13,9 & 476448 & FLNB \\
\hline АССТССАСТG & 2 & 13 & 1 & 6,17 & 0,44 & 13,9 & 112457 & KRTDAP \\
\hline GAGATAAAGC & 2 & 13 & 1 & 6,17 & 0,44 & 13,9 & \multicolumn{2}{|c|}{ [* TAG NOT FOUNDED IN MAP *] } \\
\hline TTTTATGGAA & 1 & 13 & 1 & 6,17 & 0,44 & 13,9 & 77269 & GNAI2 \\
\hline GTGCTGATTC & 10 & 38 & 3 & 18,03 & 1,33 & 13,5 & 476218 & COL7A1 \\
\hline CTGGGTGCCT & 10 & 88 & 7 & 41,75 & 3,11 & 13,4 & 89545 & PSMB4 \\
\hline
\end{tabular}




\begin{tabular}{|c|c|c|c|c|c|c|c|c|}
\hline CTGGGACTGA & 8 & 12 & 1 & 5,69 & 0,44 & 12,8 & 515255 & LSM4 \\
\hline CTATGAGCAG & 0 & 12 & 1 & 5,69 & 0,44 & 12,8 & 516301 & IL1F5 \\
\hline TGGATCAGTC & 0 & 12 & 1 & 5,69 & 0,44 & 12,8 & 53454 & TOPBP1 \\
\hline TGGTGACAAA & 0 & 12 & 1 & 5,69 & 0,44 & 12,8 & \multicolumn{2}{|c|}{ [* TAG NOT FOUNDED IN MAP *] } \\
\hline CAGCTGGCAA & 3 & 23 & 2 & 10,91 & 0,89 & 12,3 & {$\left[{ }^{*}\right.$ TAG $\wedge$} & OUNDED IN MAP *] \\
\hline TCСТCAAGAT & 5 & 11 & 1 & 5,22 & 0,44 & 11,8 & 509791 & $\mathrm{ERH}$ \\
\hline GCAAAAAAAT & 0 & 11 & 1 & 5,22 & 0,44 & 11,8 & 522310 & NANS \\
\hline АСТСССАААА & 0 & 11 & 1 & 5,22 & 0,44 & 11,8 & 406683 & RPS15 \\
\hline AAGCTAATAA & 0 & 11 & 1 & 5,22 & 0,44 & 11,8 & 201978 & PTGS1 \\
\hline TAAATAATTT & 2 & 33 & 3 & 15,66 & 1,33 & 11,8 & 1197 & HSPE1 \\
\hline AGCTTCCACC & 1 & 32 & 3 & 15,18 & 1,33 & 11,4 & 490252 & SPRR2F \\
\hline GAATAAATGT & 1 & 21 & 2 & 9,96 & 0,89 & 11,2 & 103934 & FKBP9 \\
\hline CCATAATGTT & 6 & 10 & 1 & 4,74 & 0,44 & 10,7 & 170473 & PLEK2 \\
\hline GGGGGAATTT & 1 & 10 & 1 & 4,74 & 0,44 & 10,7 & 522257 & \\
\hline GCAGGCCTCA & 1 & 10 & 1 & 4,74 & 0,44 & 10,7 & 301350 & FXYD3 \\
\hline GAAAAATAGT & 1 & 10 & 1 & 4,74 & 0,44 & 10,7 & 521461 & NEFL \\
\hline GAGGGAGCAC & 0 & 10 & 1 & 4,74 & 0,44 & 10,7 & \multicolumn{2}{|c|}{ [ ${ }^{*}$ TAG NOT FOUNDED IN MAP *] } \\
\hline TGAAATCTTT & 0 & 10 & 1 & 4,74 & 0,44 & 10,7 & 527193 & RPS23 \\
\hline СTTCTTGCСТ & 0 & 10 & 1 & 4,74 & 0,44 & 10,7 & 449630 & HBA1 \\
\hline TGGAGATCTC & 0 & 10 & 1 & 4,74 & 0,44 & 10,7 & 50098 & NDUFA4 \\
\hline TGCTAAAAAA & 9 & 30 & 3 & 14,23 & 1,33 & 10,7 & 474751 & MYH9 \\
\hline GCAACTTAGA & 13 & 19 & 2 & 9,01 & 0,89 & 10,2 & 591484 & LAMC2 \\
\hline GAGATAATGA & 5 & 19 & 2 & 9,01 & 0,89 & 10,2 & 415762 & LY6D \\
\hline GTCATAGCTG & 14 & 9 & 1 & 4,27 & 0,44 & 9,6 & 459790 & VPS13A \\
\hline TTTGTTGTAT & 6 & 9 & 1 & 4,27 & 0,44 & 9,6 & 584957 & TOR3A \\
\hline CAGCTCATCT & 2 & 9 & 1 & 4,27 & 0,44 & 9,6 & 6396 & JTB \\
\hline TCCGTGGTTG & 2 & 18 & 2 & 8,54 & 0,89 & 9,6 & 201641 & BASP1 \\
\hline AAGATAAATG & 1 & 9 & 1 & 4,27 & 0,44 & 9,6 & \multicolumn{2}{|c|}{ [* TAG NOT FOUNDED IN MAP *] } \\
\hline AAAATAAACA & 1 & 9 & 1 & 4,27 & 0,44 & 9,6 & 676357 & MEPE \\
\hline GTGCTGGTGC & 1 & 18 & 2 & 8,54 & 0,89 & 9,6 & 9613 & ANGPTL4 \\
\hline TGCCCCTGAA & 1 & 18 & 2 & 8,54 & 0,89 & 9,6 & 441975 & XAF1 \\
\hline ATGTCTCAAA & 0 & 9 & 1 & 4,27 & 0,44 & 9,6 & 495961 & CXorf38 \\
\hline CTGTCACCTG & 0 & 9 & 1 & 4,27 & 0,44 & 9,6 & 46320 & SPRR1A \\
\hline
\end{tabular}


Tabela 6. Sessenta tags mais discriminativas com redução de expressão em laringe No versus laringe normal, segundo Silveira et al., (2008). São apresentadas as frequências absolutas e normalizadas de cada tag nas bibliotecas de tumor e tecido normal, Unigene ID e símbolo do gene de acordo com a base de dados SAGEmap. A: biblioteca de laringe N+, NA: biblioteca de laringe NO, N: biblioteca de tecido normal.

\begin{tabular}{|c|c|c|c|c|c|c|c|c|}
\hline \multirow[b]{2}{*}{ Tag } & \multicolumn{3}{|c|}{ Frequência Absoluta } & \multicolumn{3}{|c|}{ Frequência Normalizada } & \multicolumn{2}{|c|}{ Anotação SAGEmap } \\
\hline & A & NA & $\mathbf{N}$ & NA & $\mathbf{N}$ & N / NA & Unigene ID & Símbolo do gene \\
\hline GTGGAAGACG & 0 & 1 & 468 & 0,47 & 207,74 & 437,9 & 80395 & MAL \\
\hline AAAGCGGGGC & 1 & 6 & 823 & 2,85 & 365,32 & 128,3 & 654550 & KRT13 \\
\hline GGCAGAGAAG & 0 & 4 & 531 & 1,90 & 235,70 & 124,2 & 697198 & \\
\hline GCTTCCTCGG & 0 & 1 & 127 & 0,47 & 56,37 & 118,8 & 459284 & RHCG \\
\hline CGTGGGGCTG & 1 & 1 & 63 & 0,47 & 27,96 & 58,9 & 298023 & AQP5 \\
\hline GACATCAAGT & 9 & 1 & 55 & 0,47 & 24,41 & 51,5 & 654568 & KRT19 \\
\hline GTGGCCCACG & 0 & 1 & 46 & 0,47 & 20,42 & 43,0 & 695954 & IL6R \\
\hline TAAAGCCTGA & 0 & 1 & 35 & 0,47 & 15,54 & 32,7 & 146239 & LOC374569 \\
\hline TCTGGAGGAG & 0 & 1 & 30 & 0,47 & 13,32 & 28,1 & 665267 & KRT78 \\
\hline ACTGCCCGCT & 3 & 2 & 50 & 0,95 & 22,19 & 23,4 & 81071 & ECM1 \\
\hline AGGGTGGTGA & 2 & 4 & 90 & 1,90 & 39,95 & 21,1 & 451636 & LOC342897 \\
\hline CAATGTACTT & 0 & 1 & 21 & 0,47 & 9,32 & 19,6 & 201877 & TMPRSS11E \\
\hline TGTGAGGTCT & 0 & 1 & 19 & 0,47 & 8,43 & 17,8 & 331555 & SPINK5 \\
\hline ATGGGGGTGA & 4 & 1 & 17 & 0,47 & 7,55 & 15,9 & 654660 & MFSD5 \\
\hline ATCGTGGCGG & 2 & 1 & 17 & 0,47 & 7,55 & 15,9 & 699253 & CLDN4 \\
\hline ACTCGTATAT & 1 & 1 & 17 & 0,47 & 7,55 & 15,9 & 81134 & IL1RN \\
\hline CCAGCGCCAA & 5 & 2 & 32 & 0,95 & 14,20 & 15,0 & 631594 & LYPD3 \\
\hline TTAGATCGTT & 1 & 1 & 16 & 0,47 & 7,10 & 15,0 & 43233 & TSPAN6 \\
\hline GTGGGCCACG & 1 & 3 & 46 & 1,42 & 20,42 & 14,3 & 648398 & IGHA1 \\
\hline GCGGCCATCC & 2 & 1 & 14 & 0,47 & 6,21 & 13,1 & 79625 & C20orf149 \\
\hline GCTGTGCCTG & 0 & 1 & 14 & 0,47 & 6,21 & 13,1 & 654513 & PRSS3 \\
\hline ATAATTGGAA & 0 & 1 & 14 & 0,47 & 6,21 & 13,1 & 643431 & IGJ \\
\hline СССТТСТАТА & 1 & 1 & 13 & 0,47 & 5,77 & 12,2 & 632641 & TMED4 \\
\hline GACGTTCACT & 0 & 1 & 13 & 0,47 & 5,77 & 12,2 & 464071 & PGD \\
\hline GGTGGGCCAC & 0 & 1 & 13 & 0,47 & 5,77 & 12,2 & 644326 & PACS1 \\
\hline ATGTAAAAAA & 9 & 8 & 103 & 3,80 & 45,72 & 12,0 & 695929 & LYZ \\
\hline CGTGGGACAC & 0 & 12 & 149 & 5,69 & 66,14 & 11,6 & 110196 & CRCT1 \\
\hline ATGACAGATG & 1 & 3 & 37 & 1,42 & 16,42 & 11,5 & 654864 & HOP \\
\hline
\end{tabular}




\begin{tabular}{|c|c|c|c|c|c|c|c|c|}
\hline AGACATAAAT & 0 & 3 & 36 & 1,42 & 15,98 & 11,2 & \multicolumn{2}{|c|}{ [* TAG NOT FOUNDED IN MAP *] } \\
\hline GGCTGCCTGC & 2 & 1 & 12 & 0,47 & 5,33 & 11,2 & 569809 & ARHGAP27 \\
\hline АСАСАСТССА & 2 & 2 & 24 & 0,95 & 10,65 & 11,2 & 408061 & FABP5 \\
\hline TCCTTCAACG & 0 & 1 & 12 & 0,47 & 5,33 & 11,2 & 139322 & SPRR3 \\
\hline GTCTGGGGGA & 0 & 1 & 12 & 0,47 & 5,33 & 11,2 & 277035 & MGLL \\
\hline GCTAACCCCT & 0 & 1 & 12 & 0,47 & 5,33 & 11,2 & 534458 & TPPP3 \\
\hline TACCCTGCAG & 0 & 2 & 24 & 0,95 & 10,65 & 11,2 & 468415 & PIGF \\
\hline GACCTCCGGG & 0 & 3 & 35 & 1,42 & 15,54 & 10,9 & 2022 & TGM3 \\
\hline GTGGCGTGCA & 0 & 3 & 35 & 1,42 & 15,54 & 10,9 & 445387 & RPS6KA3 \\
\hline GGCGTCTGCC & 0 & 9 & 101 & 4,27 & 44,83 & 10,5 & 512469 & MGC59937 \\
\hline ССАСТАСАСТ & 11 & 1 & 11 & 0,47 & 4,88 & 10,3 & 478275 & TNFSF10 \\
\hline CCTATGGCTT & 4 & 1 & 11 & 0,47 & 4,88 & 10,3 & 22242 & ECHDC3 \\
\hline GGAGCGTGGG & 3 & 1 & 11 & 0,47 & 4,88 & 10,3 & 286226 & MYO1C \\
\hline GCTTTCATTG & 1 & 1 & 11 & 0,47 & 4,88 & 10,3 & 643846 & NUCKS1 \\
\hline CAAAGCCCTG & 0 & 1 & 11 & 0,47 & 4,88 & 10,3 & 75264 & ZNF510 \\
\hline GAGATGAGCG & 0 & 1 & 11 & 0,47 & 4,88 & 10,3 & 448277 & C6orf205 \\
\hline CACACACCAG & 0 & 1 & 11 & 0,47 & 4,88 & 10,3 & 567664 & SPNS2 \\
\hline АTTTCCTTGA & 0 & 1 & 11 & 0,47 & 4,88 & 10,3 & 694721 & CD24 \\
\hline AGTGTGAAGC & 0 & 1 & 11 & 0,47 & 4,88 & 10,3 & 654610 & KRT4 \\
\hline TAGAAAGGCA & 10 & 2 & 21 & 0,95 & 9,32 & 9,8 & 503093 & ZFP36L2 \\
\hline GCGGCCACGG & 1 & 2 & 21 & 0,95 & 9,32 & 9,8 & 517729 & MLC1 \\
\hline GAGCAGGAGC & 4 & 1 & 10 & 0,47 & 4,44 & 9,4 & 438782 & HDAC5 \\
\hline AAGAAGCAGG & 4 & 1 & 10 & 0,47 & 4,44 & 9,4 & 523262 & TMEM59 \\
\hline TGTGCCCTGA & 2 & 1 & 10 & 0,47 & 4,44 & 9,4 & 580427 & HPCAL1 \\
\hline CTTCTGTGTA & 2 & 1 & 10 & 0,47 & 4,44 & 9,4 & 136778 & USP10 \\
\hline AGTTGTCCCG & 1 & 1 & 10 & 0,47 & 4,44 & 9,4 & 148078 & UBR4 \\
\hline TTCCTCCACG & 1 & 2 & 20 & 0,95 & 8,88 & 9,4 & 436500 & DBNL \\
\hline GCTTTTCTGG & 1 & 3 & 30 & 1,42 & 13,32 & 9,4 & 139322 & SPRR3 \\
\hline TCAGTATTCT & 0 & 1 & 10 & 0,47 & 4,44 & 9,4 & 528605 & LOC643008 \\
\hline GCTTGATGAA & 0 & 1 & 10 & 0,47 & 4,44 & 9,4 & 494173 & ANXA1 \\
\hline GCTTTCTCAC & 48 & 5 & 48 & 2,37 & 21,31 & 9,0 & 546269 & RPL10A \\
\hline GAATCTGGAG & 0 & 2 & 19 & 0,95 & 8,43 & 8,9 & 584864 & LTB4DH \\
\hline TATCACAGTC & 0 & 2 & 19 & 0,95 & 8,43 & 8,9 & 254338 & GBP6 \\
\hline
\end{tabular}




\section{Apêndice}

(Co-autoria em trabalho desenvolvido sobre as interações câncer-estroma) 


\title{
Genomics and proteomics approaches to the study of cancer-stroma interactions
}

\author{
Flávia C Rodrigues-Lisoni ${ }^{1,8}$, Paulo Peitl $\mathrm{Jr}^{2}$, Alessandra Vidotto ${ }^{1}$, Giovana M Polachini ${ }^{1}$, José V Maniglia ${ }^{3}$, \\ Juliana Carmona-Raphe', Bianca R Cunha', Tiago Henrique', Caique F Souza ${ }^{1,4}$, Rodrigo AP Teixeira ${ }^{2}$, \\ Erica E Fukuyama ${ }^{5}$, Pedro Michaluart $\mathrm{Jr}^{6}$, Marcos B de Carvalho ${ }^{7}$, Sonia M Oliani², \\ Head and Neck Genome Project GENCAPO ${ }^{9}$, Eloiza H Tajara ${ }^{1,4^{*}}$
}

\begin{abstract}
Background: The development and progression of cancer depend on its genetic characteristics as well as on the interactions with its microenvironment. Understanding these interactions may contribute to diagnostic and prognostic evaluations and to the development of new cancer therapies. Aiming to investigate potential mechanisms by which the tumor microenvironment might contribute to a cancer phenotype, we evaluated soluble paracrine factors produced by stromal and neoplastic cells which may influence proliferation and gene and protein expression.

Methods: The study was carried out on the epithelial cancer cell line (Hep-2) and fibroblasts isolated from a primary oral cancer. We combined a conditioned-medium technique with subtraction hybridization approach, quantitative PCR and proteomics, in order to evaluate gene and protein expression influenced by soluble paracrine factors produced by stromal and neoplastic cells.

Results: We observed that conditioned medium from fibroblast cultures (FCM) inhibited proliferation and induced apoptosis in Hep-2 cells. In neoplastic cells, 41 genes and 5 proteins exhibited changes in expression levels in response to FCM and, in fibroblasts, 17 genes and 2 proteins showed down-regulation in response to conditioned medium from Hep-2 cells (HCM). Nine genes were selected and the expression results of 6 down-regulated genes (ARID4A, CALR, GNB2L1, RNF10, SQSTM1, USP9X) were validated by real time PCR.
\end{abstract}

Conclusions: A significant and common denominator in the results was the potential induction of signaling changes associated with immune or inflammatory response in the absence of a specific protein.

\section{Background}

Solid tumors are characterized by the presence of two major components: neoplastic cells and a specialized nonmalignant stroma in which they are immersed and are essential for their survival and proliferation. In carcinomas, a basement membrane is usually present between these components $[1,2]$.

The tumor stroma is distinguished by an enrichment of microvessel density, abundance of endothelial cells and precursors, inflammatory cells including lymphocytes, neutrophils, macrophages, dendritic and mast cells, and a connective tissue with fibroblasts, myofibroblasts and

* Correspondence: tajara@famerp.br

${ }^{1}$ Department of Molecular Biology, School of Medicine (FAMERP), São José do Rio Preto, Brazil histiocytes responsible for remodeling and deposition of extracellular matrix (ECM) components - fibronectin, collagens, elastin, and glycosaminoglycans [2-4]. Although these cells are nonmalignant, they have a unique gene expression pattern, compared to stroma cells in normal tissues $[5,6]$.

Substantial evidence indicates that the development and the progression of cancer not only depend on its genetic characteristics but also on interactions with its microenvironment $[4,7,8]$. In fact, tumor cells may alter the surrounding stroma through direct cell contact or via the secretion of paracrine soluble factors, inducing cell differentiation or extracellular matrix modifications [9]. In it turn, stromal cells may promote cancer progression and acquisition of invasiveness [10-12]. It is 
possible that such interactions contribute to the neoplastic cell phenotype and behavior as observed during the normal development process and function of organs and tissues [13,14]. As Albini and Sporn (2008) appropriately propose, the microenvironment may be more than a partner but also an essential component of the cancer, and both should be considered as a functional whole [15].

In this context, inflammation and infection have gained special attention. Well known examples connecting infection-related or -unrelated chronic inflammation and increased risk for cancer development are described in the literature [16], and probably more than $15 \%$ of cancers are linked to these factors [17]. TNF-alpha and NF- $\kappa \mathrm{B}$ transcription factor should play a central role in this process, modulating transcription of genes encoding angiogenic and growth factors, inflammatory cytokines and anti-apoptotic proteins [16]. In fact, many inflammatory mediators may influence cell proliferation and tumor development, as demonstrated by our recent studies on annexin A1 [18-20].

Macrophages represent one of the main inflammatory regulators in tumor stroma and are responsible for proliferation, invasion and immunosuppressive signaling, with the production of angiogenic and growth factors, chemokines, cytokines and matrix metalloproteinases [21]. The key partners of macrophages in this network are fibroblasts, the so-called carcinoma-associated fibroblasts (CAFs), which significantly increase the growth of neoplastic or normal cells [22,23] and can enhance tumor engraftment and metastasis in animal models [24]. Recently, Hawsawi et al. (2008) [25] observed welldefined differences in gene expression and proteomic profiles between activated CAFs and fibroblasts from normal stroma, emphasizing their importance in the cancer process.

Regardless of the fact that they are easily identified by their morphology, specific cellular markers for fibroblasts remain unknown, presumably because of their large diversity [26]. In tumor stroma, fibroblasts present a phenotype similar to those associated with wound healing, with a large and euchromatic nucleus and prominent rough endoplasmic reticulum $[27,28]$. These signals mediating the transition of normal to reactive fibroblasts are still not completely defined.

Many studies have analyzed the role of fibroblasts in cancer initiation and progression. To address this issue, several approaches have been used, as co-culture of cancer cells and fibroblasts and cultures with conditioned medium, combined or not with in vivo experiments. The data have shown that these cells, similar to macrophages, overexpress chemokines, interleukines, growth factors and matrix metalloproteinases, promoting inflammatory responses and facilitating angiogenesis, cancer-cell invasion and proliferation [29-31]. In head and neck cancer, for example, in vitro experiments have suggested that the presence of fibroblasts is essential for invasive features either because cancer cells express higher levels of matrix metalloproteinases in the presence of fibroblasts $[32,33]$ or because cancer-associated fibroblasts themselves synthesize these proteins [34,35].

Much of the answer to the question of tumor-stroma interactions lies in the identity of ligands, receptors and effectors of signaling patterns expressed by stroma and tumor cells. Numerous growth factors, cytokines, chemokines, hormones, enzymes and cells responsible for their expression have been characterized but the cross-signaling between pathways in this complex network is far from solved $[7,36]$. Adding complexity to the scenario, the chemomechanical environment of the extracellular matrix may also act in concert with signaling pathways and affect the cancer process [37].

An important perspective in the study of tumor stroma is the potential use of the gene expression pattern of their cells for diagnostic or prognostic evaluation and as a target for therapy. Supporting this idea are the results from studies on outcome prediction and molecular marker analysis of the stroma [6,38], drugs targeting inflammatory cells [39] and mediators of angiogenesis $[40,41]$.

In order to investigate potential mechanisms by which the tumor microenvironment might contribute to cancer phenotype, we asked whether soluble paracrine factors produced by stromal and neoplastic cells in vitro may influence proliferation, and gene and protein expression. For these purposes, we exploited purified fibroblasts isolated from a primary oral cancer and an epithelial cancer cell line linked by conditioned medium and genomic and proteomic approaches. Both cells were treated with the conditioned medium of each other and submitted to analysis by rapid subtraction hybridization methodology, two-dimensional electrophoresis and mass spectrometry. Based on the results of the rapid subtraction hybridization ( $\mathrm{RaSH})$ approach, a comparative quantitative realtime PCR was performed to validate the expression of several genes, focusing on those involved in tumorigenesis and inflammation. The results pointed to the participation of several inflammatory mechanisms that might have biological significance in epithelial tumors.

\section{Methods \\ Primary tumor samples}

For conditioned medium experiments, a primary epidermoid (squamous cell) carcinoma of the retromolar area was obtained from a 49-year-old male patient, prior to radiation and/or chemotherapy. Twenty-four laryngeal and 23 oral tongue squamous cell carcinoma (SCC) samples from patients undergoing tumor resection were 
used for gene expression analysis. All carcinoma samples were reviewed by senior pathologists and exhibited the presence of at least $70 \%$ tumor cells; the corresponding surgical margins were classified to be free of tumor cells.

The study protocol was approved by the National Committee of Ethics in Research (CONEP 1763/05, 18/ $05 / 2005$ ), and informed consent was obtained from all patients enrolled.

Epithelial cancer cell line and primary tumor cell cultures The Hep-2 cell line, originally established from an epidermoid carcinoma of the larynx (ATCC, Rockville, Maryland, USA), was seeded at a density of $1 \times 10^{6}$ cells $/ \mathrm{mL}$ per $75 \mathrm{~cm}^{2}$ culture flask (Corning, NY, USA) in medium MEM-Earle (Cultilab, Campinas, SP, Brazil), pH 7.5, supplemented with $20 \%$ fetal calf serum (Cultilab), $1 \%$ non-essential amino acids, $0.1 \%$ antibiotic/antimycotic (Invitrogen Corporation, Carlsbad, CA, USA), and cultured at $37^{\circ} \mathrm{C}$ in a humid atmosphere of $5 \% \mathrm{CO}_{2}$.

A primary carcinoma of retromolar area sample showing epithelium and adjacent connective tissues was rinsed multiple times with $100 \times$ antibiotic and antimycotic solutions (Invitrogen) and minced into $2-4 \mathrm{~mm}$ fragments. Single-cell suspensions were obtained by digestion at $37^{\circ} \mathrm{C}$ for 1 hour with $40 \mathrm{mg} / \mathrm{mL}$ collagenase type I (Sigma Chemical, St Louis, USA). After centrifugation, the cells were washed with PBS, resuspended in DMEM medium supplemented with $20 \%$ fetal calf serum (Cultilab), $2 \mathrm{mM}$ glutamine (Invitrogen), 1\% nonessential amino acids (Invitrogen), and $0.1 \%$ antibiotic/ antimycotic (Invitrogen). The cells were seeded at a density of $1 \times 10^{6}$ cells $/ \mathrm{mL}$ per $75 \mathrm{~cm}^{2}$ culture flasks (Corning) and cultured at $37^{\circ} \mathrm{C}$ in a humid atmosphere of $5 \% \mathrm{CO}_{2}$. Cell medium was changed at $72 \mathrm{~h}$ intervals until the cells became confluent. Since fibroblasts were mixed with the epithelial tumor cells at the time of initial plating, fibroblasts were selected by plating the cells growing in medium supplemented with $20 \%$ serum for at least 3 weeks [42-44]

\section{Preparation of conditioned medium}

Conditioned medium (CM) was prepared from Hep-2 cell or tumor stromal fibroblast cultures showing $80 \%$ confluence. Twenty-four, 48 and 72 hours after medium replacement, the supernatant or conditioned medium (CM24, CM48 and CM72, respectively) from three replicas was aspirated and filtered through a $0.22 \mu \mathrm{m}$ membrane (Millipore) to remove any cell debris and stored at $-80^{\circ} \mathrm{C}$. Before using, the $\mathrm{CM}$ was diluted $1: 1$ in complete medium. The dilution 1:1 and CM72 were chosen to maximize the chance of detecting a cell response to soluble factors. Optimization experiments showed that dilutions lower than 1:1 resulted in higher numbers of dead cells.
Hep-2 cell-conditioned medium is referred to as HCM and fibroblast-conditioned medium is referred to as FCM.

\section{Growth curve}

Hep- 2 cells were seeded at a density of $5 \times 10^{4}$ cells in plastic 6-well plates in two sets of quadruplicates. Twenty-four hours later, when cells had already adhered, Hep-2 cultures were incubated with FCMs. One replica in each set was treated with self-conditioned medium and one replica was treated with complete medium.

Medium was replaced on day 4 and cell morphology was observed every day. After 1, 3, 5 and 7 days, cells were harvested and counted using a Neubauer hemocytometer. The same experiment was repeated twice.

\section{Immunofluorescence analysis}

The Hep-2 cell line or tumor stromal fibroblasts were grown in culture chambers (Nunc, Naperville, IL, USA) and, after 3 days, the chambers were carefully removed, and the slides with adherent cells were fixed in $4 \%$ paraformaldehyde and $0.5 \%$ glutaraldehyde, $0.1 \mathrm{~mol} / \mathrm{L}$ sodium phosphate buffer, $\mathrm{pH} 7.4$, for 2 hours at $4^{\circ} \mathrm{C}$. The slides were washed in the same buffer and incubated with $0.1 \%$ albumin bovine and $3 \%$ normal serum in PBS (PBSA) to block nonspecific binding. The cells were immunostained with primary mouse monoclonal antibodies (Ab) anti-vimentin (NCL-VIM-V9, Novocastra, Benton Lane, Newcastle, UK) or anti-cytokeratin (M3515, antibodies to all types of cytokeratins; AE1AE3; Dako, Carpinteria, CA, USA) diluted at 1:200 in $1 \%$ PBSA, followed by overnight incubation at $4^{\circ} \mathrm{C}$. For negative controls, the cells were incubated with nonimmune mouse serum (1:200 working dilution; SigmaAldrich). After repeated washings in 1\% PBS, a goat anti-mouse IgG (Fc fragment-specific, Dako, Glostrup, Denmark) antibody conjugated to FITC (1:50; British BioCell International, Cardiff, UK) was added, followed by 1 hour incubation at room temperature. Thus, the cells were washed thoroughly in PBS. Analysis was conducted using an Axioskop 2 light microscope (Zeiss, GR) equipped with a digital camera. Digital images were captured by using software AxioVision (Zeiss, GR).

\section{Immunohistochemical analysis}

Apoptosis was assayed using AnxA5 staining as described [45]. Fixed Hep-2 cell line or tumor stromal fibroblast in slides from culture chambers were incubated with the following reagents: $2.1 \%$ sodium citrate for $30 \mathrm{~min}$ at $96^{\circ} \mathrm{C} ; 3 \%$ hydrogen peroxide for $15 \mathrm{~min}$; $0.1 \%$ Tween 20 (Sigma-Aldrich) diluted in $0.4 \%$ PBS for $15 \mathrm{~min}$; non-specific binding sites were blocked with $10 \%$ albumin bovine (BSA) diluted in TBS $(20 \mathrm{mM}$ Tris 
buffer in $0.9 \% \mathrm{NaCl}, \mathrm{pH} 8.2$ ) for $30 \mathrm{~min}$. The slides were then incubated overnight with a rabbit polyclonal antibody anti-AnxA5 (sc8300, Santa Cruz Biotechnology, California, USA), diluted 1:200. After repeated washings in $1 \%$ PBSA, a goat anti-rabbit IgG (Fc fragment specific) antibody conjugated to $5 \mathrm{~nm}$ colloidal gold particles (N24916, Invitrogen) was added. Silver enhancing solution (L24919, Invitrogen) was used to augment gold particle staining. At the end of the reaction, cells were washed thoroughly in distilled water, counterstained with haematoxylin and examined using an Axioskop2 microscope (ZEISS, GR).

\section{RNA extraction for Rapid Subtraction Hybridization} (RaSH) and real time PCR experiments

Hep- 2 cells and stromal fibroblasts were seeded at a density of $1 \times 10^{6}$ cells $/ \mathrm{mL}$ per $75 \mathrm{~cm}^{2}$ culture flasks in complete medium (controls) and in conditioned medium. Hep-2 cells and fibroblasts were cultured for 5 and 3 days, respectively, and harvested by addition of TRIzol Reagent, following treatment with DNase (Invitrogen). Total RNA from primary tumor samples was also extracted using TRIzol Reagent and treated with DNase. cDNA synthesis was performed using a High Capacity cDNA Archive kit (Applied Biosystems, Foster City, CA, USA) as described by the manufacturer.

\section{RaSH}

$\mathrm{RaSH}$ technique was performed as described by Jiang et al. (2000) [46]. Aliquots $(20 \mu \mathrm{g})$ of total RNA from control cells (driver) or treated cells (tester) were used for double-stranded cDNA synthesis using standard protocols [47].

The cDNA was digested with MboI (Invitrogen) at $37^{\circ} \mathrm{C}$ for $3 \mathrm{~h}$ followed by phenol/chloroform extraction and ethanol precipitation. The digested cDNAs were mixed with the adaptors XPDN-14 5'-CTGATCACTCGAGA and XPDN-12 5'-GATCTCTCGAGT (Sigma Chemical, final concentration $20 \mu \mathrm{M}$ ) in $30 \mu \mathrm{l}$ of $1 \times$ ligation buffer (Gibco BRL), heated at $55^{\circ} \mathrm{C}$ for $1 \mathrm{~min}$, and cooled down to $14^{\circ} \mathrm{C}$ within $1 \mathrm{~h}$. After adding $3 \mu \mathrm{l}$ of T4 DNA ligase (5 U/ $\mu \mathrm{l})$ (Gibco, BRL), ligation was carried out overnight at $14^{\circ} \mathrm{C}$. After phenol/chloroform extraction and ethanol/glycogen precipitation, the mixtures were diluted to $100 \mu \mathrm{l}$ with TE buffer $(10 \mathrm{mM}$ Tris/ $1 \mathrm{mM}$ EDTA); $40 \mu \mathrm{l}$ of the mixtures were used for PCR amplification.

The PCR mixtures were set up using $10 \mu \mathrm{M}$ XPDN-18 5'-CTGATCACTCGAGAGATC, $0.4 \mathrm{mM}$ dNTPs, $10 \times$ PCR buffer, $1.5 \mathrm{mM} \mathrm{MgCl}_{2}$ and $1 \mathrm{U}$ Taq DNA polymerase (Invitrogen). Thermocycler conditions were one cycle at $72^{\circ} \mathrm{C}$ for $5 \mathrm{~min}$, followed by 25 cycles of $94^{\circ} \mathrm{C}$ for $1 \mathrm{~min}, 55^{\circ} \mathrm{C}$ for $1 \mathrm{~min}, 72^{\circ} \mathrm{C}$ for $1 \mathrm{~min}$, ending in a final extension at $72^{\circ} \mathrm{C}$ for $3 \mathrm{~min}$. Ten $\mu \mathrm{g}$ of purified
PCR product (tester) was digested with 20U XhoI (Invitrogen) followed by phenol/chloroform extraction and ethanol precipitation.

One-hundred nanograms of the tester cDNA were mixed with $5 \mu \mathrm{g}$ of the driver cDNA in hybridization solution (0.5 M Nacl, $50 \mathrm{mM}$ Tris/ $\mathrm{HCl}, \mathrm{SDS} 2 \%$ and $40 \%$ formamide) and, after heating at $95^{\circ} \mathrm{C}$, incubated at $42^{\circ} \mathrm{C}$ for $48 \mathrm{~h}$. After extraction and precipitation, the hybridization mixture $(1 \mu \mathrm{g})$ was ligated with XhoIdigested pZero plasmid and transformed into competent bacteria. Bacterial colonies were picked and used as DNA template for PCR. Clones were sequenced using an automated DNA sequencer and sequence homologies were searched using the BLAST program [48]. Gene ontology (GO) annotation was used for the functional classification of up- and down-regulated genes [49].

\section{Quantitative PCR}

For validation experiments, cells were seeded at a density of $1 \times 10^{6}$ cells $/ \mathrm{mL}$ per $75 \mathrm{~cm}^{2}$ culture flasks in two sets of quadruplicates. Twenty-four hours later, when cells had already adhered, Hep- 2 culture replicas were treated with FCMs and fibroblast cultures were treated with HCMs. One replica in each set (control) was treated with self-conditioned medium. Hep-2 cells and fibroblasts were harvested after 5 and 3 days, respectively, and RNA was extracted as described above.

Nine differentially expressed genes were selected for validation by quantitative real time PCR experiments according to their direct or indirect involvement in tumorigenesis. Their expression was checked in treated samples relative to matched non-treated samples. One of these genes (ARID4A) was also selected for quantitative real time PCR validation in fresh tumor samples of 24 laryngeal SCC and in 23 oral tongue SCC relative to matched normal samples.

The primers were manually designed with: 19-23 bp length, 30-70\% GC content and a short amplicon size (90-110 bp). Their sequences are available upon request. Real time PCR was performed in triplicate using a 7500 Fast Real-Time PCR System (Applied Biosystems). Reaction mixture consisted of a 20 ul volume solution containing $10 \mathrm{ul}$ of Power SYBR Green PCR Master Mix (Applied Biosystems), $500 \mathrm{nM}$ of each primer and $100 \mathrm{ng}$ cDNA. The PCR conditions were $95^{\circ} \mathrm{C}$ for $10 \mathrm{~min}$ followed by 40 cycles of $95^{\circ}$ for $15 \mathrm{~s}$ and $60^{\circ}$ for $1 \mathrm{~min}$. Melting curve analysis was performed for each gene to check the specificity and identity of the RT-PCR products.

For each primer set, the efficiency of the PCR reaction (linear equation: $\mathrm{y}=$ slope + intercept) was measured in triplicate on serial dilutions of the same cDNA sample. The PCR efficiency (E) was calculated by the formula $E=\left[10^{(-1 / \text { slope })}\right]$ and ranged from 1.96 to 2.02 in the different assays. 
Three control genes (GAPDH, ACTB and TUBA6) were used as internal standards. The relative expression ratio (fold change) of the target genes was calculated according to Pfaffl (2001) [50]. Statistical analysis was performed by a two-tailed unpaired $t$ test using GraphPad prism software.

Proteomic analysis

Hep- 2 cells and stromal fibroblasts were seeded at a density of $1 \times 10^{6}$ cells $/ \mathrm{mL}$ per $75 \mathrm{~cm}^{2}$ culture flasks in complete medium and in conditioned medium, as described for RASH experiments. Hep- 2 cells and fibroblasts were cultured for 5 and 3 days, respectively, and harvested by centrifugation at $3200 \mathrm{rpm}$ for $5 \mathrm{~min}$ at $4^{\circ} \mathrm{C}$. Cells were disrupted by sonication, proteins were isolated and twodimensional electrophoresis (2-DE) was performed, as described by de Marqui et al. (2006) [51]. Briefly, isoelectric focusing was carried out in a IPGphor (GE Healthcare) using 13-cm immobilized pH 3-10 L gradient strips. Vertical $12.5 \%$ SDS-PAGE was performed in a SE 600 Ruby electrophoresis unit (GE Healthcare) and proteins were detected by Coomassie Blue staining. Differentially expressed proteins were excised from gel, distained, dried and in-gel tryptic-digested. Negative and positive control digests were performed on gel slices that contained no protein and on slices cut from a band of the molecular weight marker, respectively.

Samples were analyzed using MALDI Q-TOF (Matrix Assisted Laser Desorption Ionization - Quadrupole Ion Filter - Time of Flight) Premier (Waters Corporation, Milford, MA, USA) mass spectrometer (MS/MS). Duplicate or triplicate runs of each sample were made to ensure an accurate analysis.

For protein identification, the resulting MS/MS data were interpreted by MASCOT software (MS/MS Ions Search) [52] and searched against the Mass Spectrometry Protein Sequence Database (MSDB). The UniProtKB/ Swiss-Prot [53] database was used for the functional classification of up- and down- expressed proteins.

\section{Data Handling and Statistical Analysis}

Quantification of apoptotic cells was performed with a high magnification objective $(\times 40)$ counting cells in $100 \mu \mathrm{m}^{2}$ areas and reported as mean \pm SEM per group. Densitometric analysis for the immunofluorescence staining used an arbitrary scale ranging from 0 to 255 units. Statistical differences between groups were determined by analysis of variance followed, if significant, by the Bonferroni test.

\section{Results}

Stromal fibroblasts: selection and immunofluorescence analysis

Fetal calf serum concentration and culture time provided a simple method of selecting fibroblasts from a primary carcinoma of retromolar area. Fibroblast cultures at passage 78 still showed spindle-shaped cells, which displayed the typical fibroblast markers, weak cytokeratin and intense vimentin immunoreactivity in cytoplasm, after immunofluorescence analysis (Figure $1 B, E)$. Staining was obtained with both antibodies (cytokeratin and vimentin) in Hep- 2 cells (Figure 1C, F). No labeling was detected in sections incubated with the control nonimmune mouse serum (Figure 1A, D).

Ultrastructural analysis showed that the stromal fibroblasts present large euchromatic nuclei, more granular endoplasmatic reticulum, mitochondria and nucleoli than normal fibroblasts (data not shown). Therefore, the spontaneously immortalized cell line of fibroblasts retained the characteristics of stromal cells and may correspond to cancer-associated fibroblasts (CAF).

Conditioned medium inhibits proliferation and induces apoptosis

Growth curves of Hep-2 cells treated with FCM showed decreased proliferation (Figure 2). Growth inhibition was observed as early as day 1 and was statistically significant $(\mathrm{P}<0.05)$ at day 3 and day 5.

The immunohistochemistry reaction with AnxA5 antibody showed the presence of gold particles on the cytoplasm of the Hep-2 apoptotic cells (Figure 3 ). The AnxA5 immunoreactivity was found more in the apoptotic process of Hep- 2 cells incubated in FCM (56\%) than in cells without the treatment (24\%). Apoptotic cells displayed distinctive morphology, a notable decrease in the nuclear size, irregular shape and cytoplasmic blebbing.

\section{Genes identified using the RaSH approach}

A total of 81 clones from the Hep- 2 cell line and fibroblast libraries were sequenced. In the Hep-2 cell line, forty-one genes exhibited changes in expression levels in response to FCM treatment (33 down- and 8 up-regulated) and, in fibroblasts, 17 genes showed down-regulation in response to HCM treatment. These genes are involved in response to stimulus, apoptosis, cell proliferation and differentiation, signal transduction, transcription, translation and transport (Table 1 and 2).

Real-time PCR validation of differentially expressed genes Nine genes displaying down- (ARID4A, CALR, GNB2L1, GPNMB, RNF10, SQSTM1, USP9X) or up-regulation $(D A P 3, P R D X 1)$ in Hep-2 cells treated with FCM were selected and the expression data for six down-regulated genes (ARID4A, CALR, GNB2L1, RNF10, SQSTM1, USP9X) were confirmed by real time PCR (Figure 4A). Most results were, therefore, consistent with the RaSH data. 

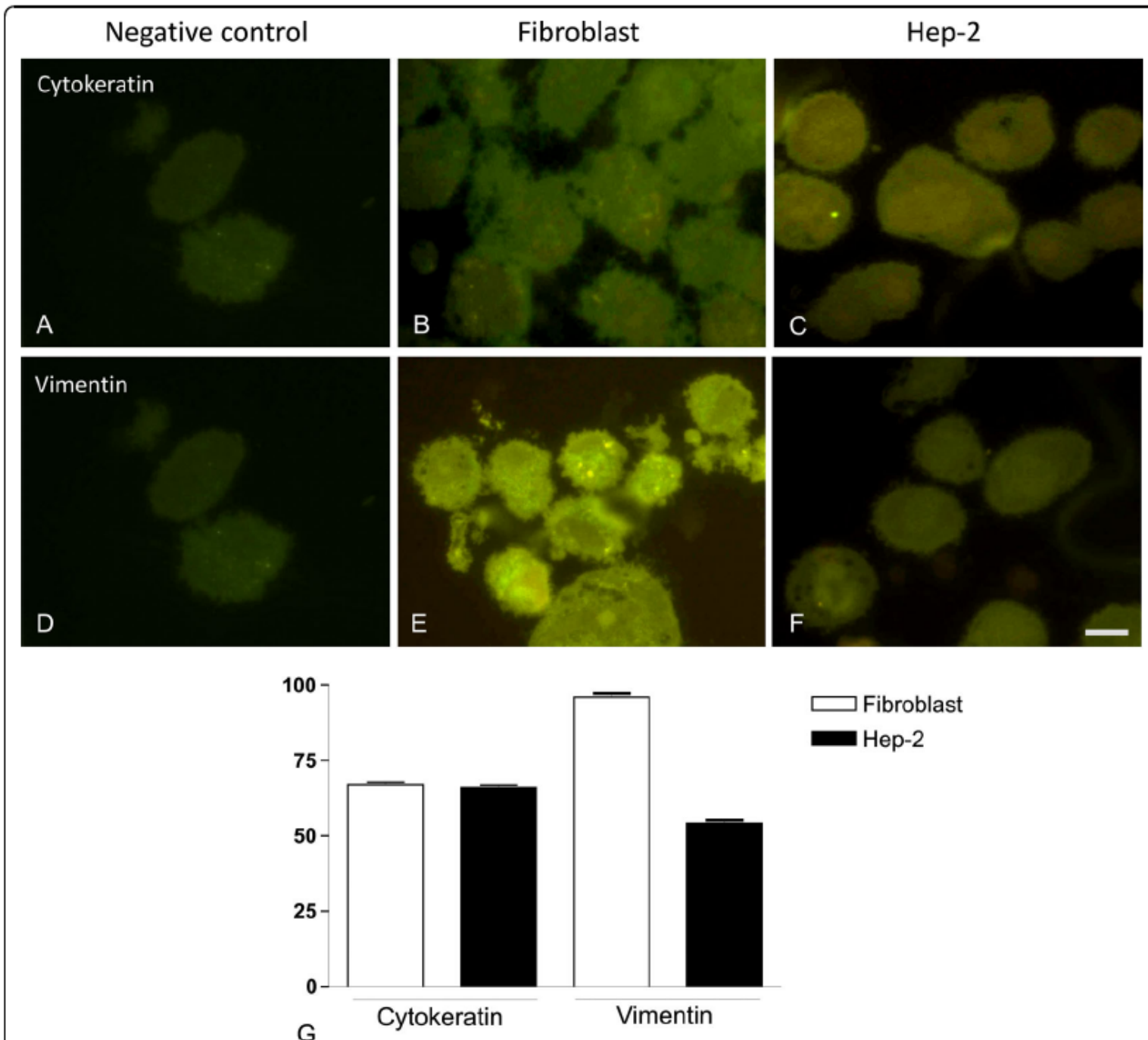
$\square$ Fibroblast
Hep-2

G

Figure 1 Immunofluorescence analysis of cytokeratin and vimentin in stromal fibroblasts and Hep-2 cell line. (A and D) Absence of immunoreactivity in sections incubated with control nonimmune mouse serum. Stromal fibroblasts ( $B$ and $E$ ) and Hep-2 cell line (C and F) were positive for vimentin and cytokeratin, respectively. $(G)$ : Densitometric analysis of immunofluorescence reaction to vimentin and cytokeratin in stromal fibroblasts and Hep-2 cell line. Scale bar, $20 \mu \mathrm{m}$.

ARID4A expression was also analyzed in 24 pairs of tumor and matched normal tissues from laryngeal squamous cell carcinomas and in 23 pairs of tumor and matched normal tissues from oral tongue squamous cell carcinomas. ARID4A mRNA levels were decreased $(\geq 2$ fold) in almost half of the squamous cell carcinomas samples ( -1.04 to -6.9 -fold change, 23 of 47 samples, i.e., $49 \%)$ and were increased in some of these samples (1.51 to 6.26 -fold change, 7 of 47 samples, i.e., 15\%) (Figure 4B). In contrast, no differences in transcript levels were observed between 17 of 47 samples (36\%) and normal tissue. Therefore, similarly to the Hep- 2 cell line, most primary head and neck tumors (49\%) showed downregulation of ARID4A transcripts.

No differences were observed in respect to clinicopathological features between samples presenting upand down-regulation of ARID $4 A$ transcripts (Additional file 1).

\section{Proteomics approach}

Comparison between 2-DE patterns from treated cells and controls revealed approximately 80 spots with significant differences in intensity. Seven proteins (Figure 5) showing expression level changes in response 


\section{Hep-2}

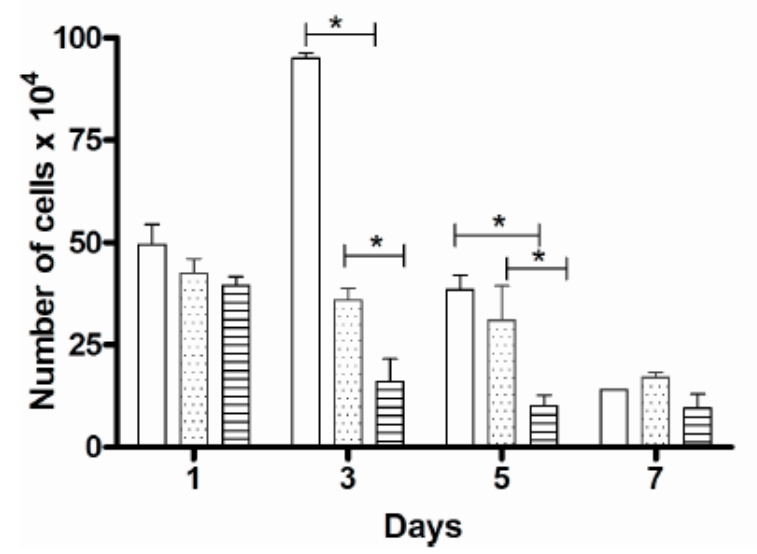

Figure $\mathbf{2}$ Growth curve of Hep-2 cell line. Hep-2 cells were cultured in complete medium, treated with self-conditioned medium (HCM) or with conditioned medium from fibroblast cultures (FCM) and collected 1, 3, 5 and 7 days after medium replacement. Data are means \pm s.d. of two independent experiments in duplicates. ${ }^{*} P<0.05$. Error bars indicate S.D.

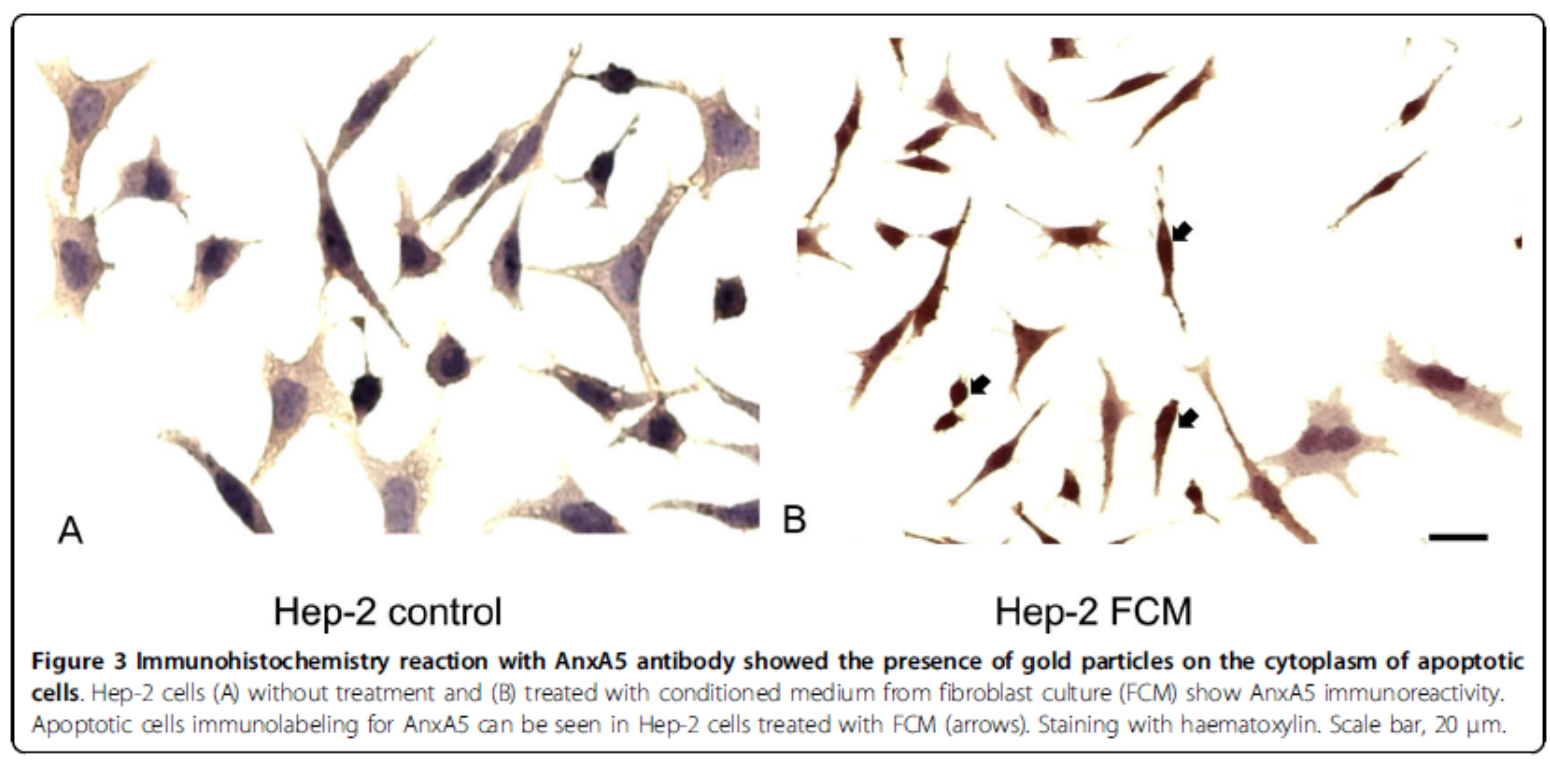

to CM treatment were identified by MALDI-Q-TOF-MS mass spectrometry (Additional file 2). Five proteins (alpha enolase, heterogeneous nuclear ribonucleoprotein $\mathrm{C} \mathrm{C1/C2}$, aldolase A, tubulin beta and glyceraldehyde-3phosphate dehydrogenase) were down-regulated in Hep2 cell line treated with conditioned medium (FCM72) and two proteins (vimentin and actin) were underexpressed in fibroblasts treated with Hep-2 cell line conditioned medium (HCM72). These proteins are involved in transcription, growth control, response to stimulus, RNA processing, glycolysis, cell motion and membrane trafficking.

\section{Discussion}

The molecular crosstalk between neoplastic and the surrounding tissue induces several stromal changes, including neoangiogenesis and immune/inflammatory reaction, as well as new extracellular matrix formation and the activation of fibroblast-like cells, a process known as desmoplasia [54], [55]. Initially, the desmoplastic response was considered a barrier against tumor invasion, but there is growing evidence that desmoplasia is an unfavorable prognostic factor. For example, Sis et al. [56] suggested that desmoplastia is related to increased risks of regional metastases, poorly differentiated 
Table 1 Information on biological processes based on Gene ontology

\begin{tabular}{|c|c|}
\hline Biological Process & Down-regulated genes \\
\hline \multicolumn{2}{|l|}{ Cell communication } \\
\hline signal transduction & FAS, SQSTM1, YWHAZ \\
\hline Transcription & $\begin{array}{l}\text { ARID4A, CALR, MYC, PARP1, } \\
\text { RNF10, SQSTM1 }\end{array}$ \\
\hline Translation & $A A R S, R P L P O, R P S 17, R P S 23$ \\
\hline Apoptosis & $C A L R$ \\
\hline induction & FAS \\
\hline anti-apoptosis & TPT1, YWHAZ \\
\hline Cell migration & TMSB $4 X$ \\
\hline Cell cycle & DYNC1 H1, MYC, PSMC6 \\
\hline \multicolumn{2}{|l|}{ Cell proliferation } \\
\hline negative regulation & GPNMB, LDOC1 \\
\hline positive regulation & MYC \\
\hline \multicolumn{2}{|l|}{ Developmental process } \\
\hline epidermis development & UGCG \\
\hline \multicolumn{2}{|l|}{ Response to stimulus } \\
\hline \multicolumn{2}{|l|}{ defense response } \\
\hline inflammatory response & LTA4H \\
\hline response to stress & EIF2AK1, SQSTM1 \\
\hline \multicolumn{2}{|l|}{ response to oxidative stress } \\
\hline response to external stimulus & EIF2AKI \\
\hline Transport & CALR, NDUFA4, SQSTM1 \\
\hline Metabolic process & $\operatorname{COX} 7 \mathrm{C}, \mathrm{OLA1}$ \\
\hline protein metabolic process & PARP1, SQSTM1, USP9X \\
\hline protein modification process & $\begin{array}{l}\text { GRPEL 2, HSP9OAB1, PPP 2R2A, } \\
\text { PRPF } 4 B \text {, USP48 }\end{array}$ \\
\hline lipid metabolic process & LTA4H, UGCG \\
\hline DNA repair & PARP1 \\
\hline RNA processing & PRPF $4 B, S F 3 B 1$ \\
\hline Cellular homeostasis & CALR, MYC, RPS17 \\
\hline \multirow[t]{2}{*}{ No classification } & GNB2L1, RCN1 \\
\hline & Up-regulated genes \\
\hline Transcription & ENO1 \\
\hline Translation & EIFI, TARS \\
\hline Apoptosis & RTN3 \\
\hline induction & $D A P 3$ \\
\hline Cell proliferation & PRDX1 \\
\hline negative regulation & ENO1 \\
\hline \multicolumn{2}{|l|}{ Developmental process } \\
\hline organ development & PRDX1 \\
\hline \multicolumn{2}{|l|}{ Response to stimulus } \\
\hline response to stress & EIF1, RTN3 \\
\hline \multicolumn{2}{|l|}{ protein metabolic process } \\
\hline protein modification process & P4HB \\
\hline \multicolumn{2}{|l|}{ nucleic acid metabolic process } \\
\hline RNA processing & USP39 \\
\hline
\end{tabular}

Top down- and up-regulated genes selected by RaSH in Hep-2 samples treated with FCM.
Table 2 Information on biological processes based on Gene Ontology

\begin{tabular}{|c|c|}
\hline Biological Process & Down-regulated genes \\
\hline \multicolumn{2}{|l|}{ Cell communication } \\
\hline signal transduction & S100A6, FN1 \\
\hline Transcription & FOSLI \\
\hline Translation & RPL37A, RPL7, RPL 19, RPL27A, RPLPO \\
\hline Apoptosis & $C T S B$ \\
\hline anti-apoptosis & TPT1 \\
\hline Cell adhesion & $\mathrm{FN} 1$ \\
\hline \multicolumn{2}{|l|}{ Cell proliferation } \\
\hline positive regulation & S100A6, FOSL1 \\
\hline \multicolumn{2}{|l|}{ Developmental process } \\
\hline \multicolumn{2}{|l|}{ organ development } \\
\hline epidermis development & COL1A1 \\
\hline \multicolumn{2}{|l|}{ Response to stimulus } \\
\hline defense response & FOSLI \\
\hline response to stress & FN1 \\
\hline Transport & ERGIC3, STX4 \\
\hline \multicolumn{2}{|l|}{ Metabolic process } \\
\hline protein metabolic process & $C T S B$ \\
\hline RNA processing & PRPF3 \\
\hline No classification & CIZ1, POLE4 \\
\hline
\end{tabular}

Top down-regulated genes selected by RaSH in CAF samples treated with $\mathrm{HCM}$.

primary tumors and lymphatic and venous invasion in colorectal carcinoma. Similar results were observed for head and neck squamous cell carcinomas, which show a high risk of neck recurrence in presence of a desmoplastic stromal pattern [57].

In the present study, we investigated the influence of soluble paracrine factors produced in vitro by stromal cells derived from an oral carcinoma and by a neoplastic epithelial cell line on proliferation and gene/protein expression. First, we noted that conditioned medium from stromal fibroblast cultures inhibited Hep-2 cell line proliferation and induced apoptosis, suggesting that factors secreted by fibroblasts include proteins that interfere in cell growth and death of neoplastic cells. In addition, using rapid subtraction hybridization and proteomic analysis, we identified gene products generated by stromal and neoplastic cells that may influence proliferation, differentiation and apoptosis, or drive response to stimulus.

Down-regulated genes in neoplastic cells treated with FCM are involved in signal transduction (FAS, SQSTM1, YWHAZ), transcription (ARID4A, CALR, MYC, PARP1, RNF10, SQSTM1), translation (AARS, RPLP0, RPS17, RPS23), apoptosis (CALR, FAS, TPT1, YWHAZ), cell migration (TMSB4X, GNB2L1), cell cycle and cell proliferation (DYNC1H1, GPNMB, LDOC1, MYC, PSM), 


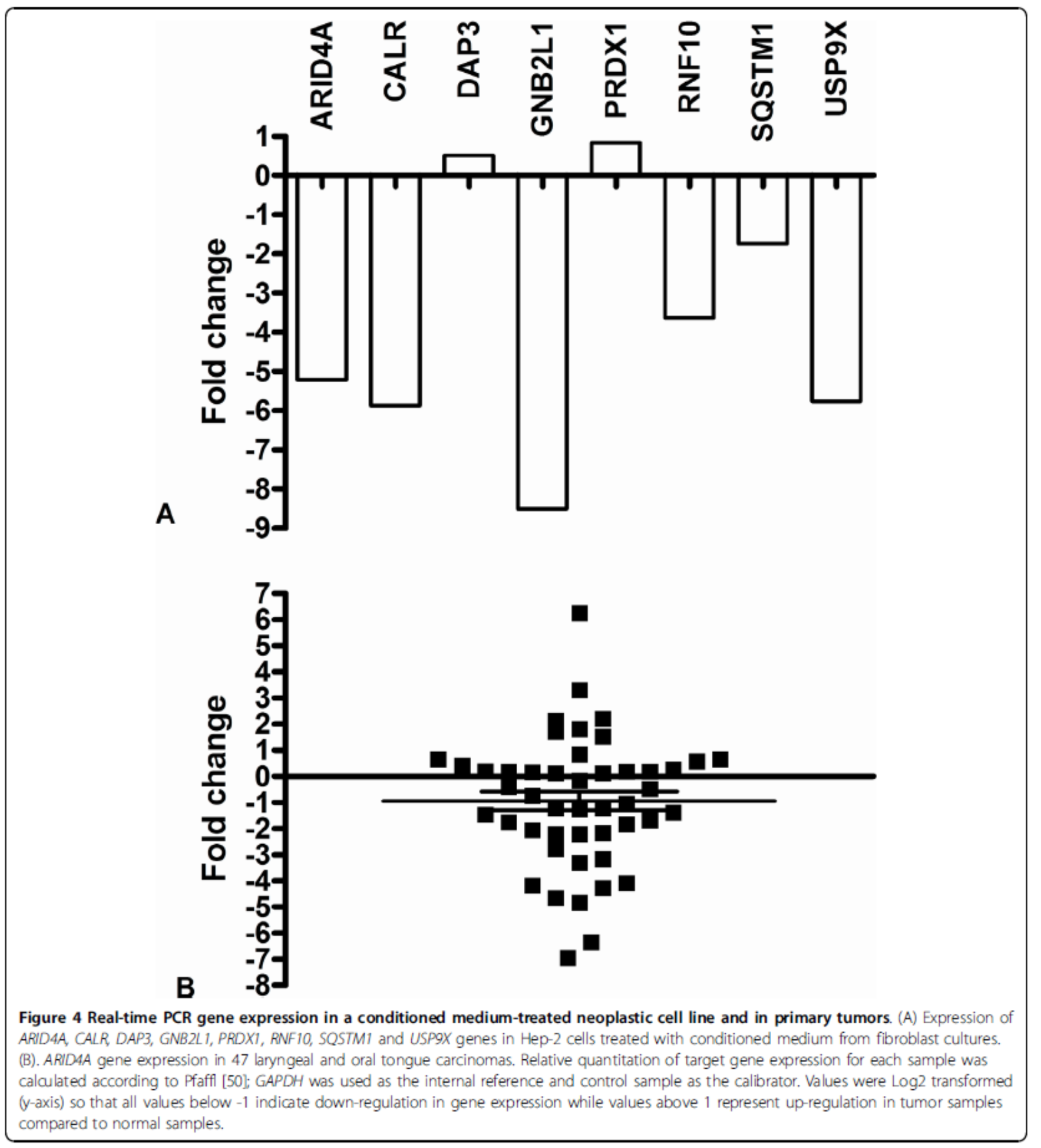

epidermis development (UGCG), response to stimulus (EIF2AK1, LTA4H, SQSTM1), transport (CALR, NDUFA4, SQSTM1) and different metabolic processes (USP9X). Up-regulated genes are also involved in transcription and translation (ENO1, EIF1, TARS), apoptosis (DAP3, RTN3), cell proliferation (PRDX1, ENO1), organ development (PRDX1), response to stress (EIF1, RTN3) and metabolic processes (PRDX1, P4HB, USP39).
In fibroblasts treated with $\mathrm{HCM}$, the biological processes of down-regulated genes include signal transduction (S100A6, FN1), transcription and translation (FOSL1, RPL37A, RPL7, RPL19, RPL27A, RPLPO), apoptosis (CTSB, TPT1), cell proliferation (S100A6, FOSL1), epidermis development (COL1A1), response to stimulus (FN1, FOSL1), transport (ERGIC3, STX4) and protein and RNA metabolism (CTSB, PRPF3). 

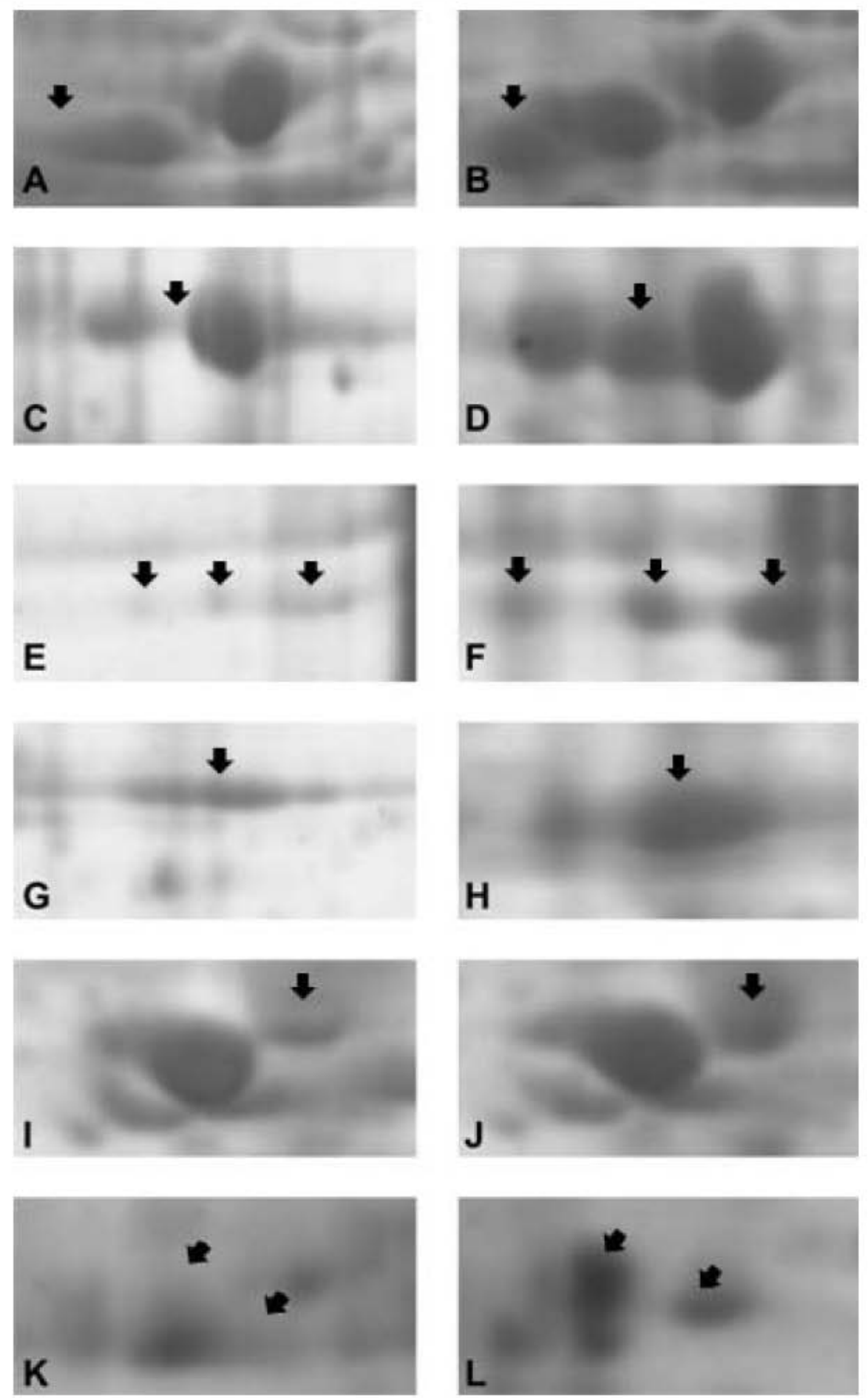

Figure 5 Enlarged 2-DE gels of proteins from conditioned medium-treated Hep-2 cells and stromal fibroblasts. Five proteins (arrows) tubulin beta ( $A-B)$, alpha enolase ( $C-D)$, aldolase $A(E-F)$, glyceraldehyde-3-phosphate dehydrogenase $(G-H)$ and heterogeneous nuclear

ribonucleoprotein $C(I-S)$ were down-regulated in Hep-2 cell line treated with fibroblast conditioned medium (A, C, E, G and I) and two proteins $(\mathrm{K}-\mathrm{L})$, vimentin (arrow on left) and actin (arrow on right), were underexpressed in fibroblasts treated with Hep-2 cell line conditioned medium (K). 
Two genes exhibited similar patterns in both cells (RPLP0, TPT1), which may indicate that the transcript levels are affected by soluble paracrine factors produced by either fibroblasts or neoplastic cells or by other in vitro conditions. Therefore, they may not be specific to interactions between stroma and tumor.

After literature analysis, nine genes (ARID4A, CALR, GNB2L1, GPNMB, RNF10, SQSTM1, USP9X, PRDX1 and $D A P 3$ ) showing potential involvement in signaling cascades related to tumorigenesis and/or stromal/tumor cell interactions were selected for validation by real-time RT-PCR using treated and non-treated cell lines. For six genes (ARID4A, CALR, GNB2L1, RNF10, SQSTM1, USP9X), the results were consistent with the RASH data. In almost half of the primary tumors analyzed, ARID4A transcripts also showed down-regulation, although no correlation with clinicopathological features was detected. These findings in primary tumors should reflect the complex network of a multi-cellular tissue, a situation contrasting with that of a neoplastic cell line cultured in medium conditioned by fibroblasts.

The product of ARID $4 A$ - AT rich interactive domain 4A (RBP1-like) - also known as RBP1 or RBBP1 gene, interacts with the tumor suppressor retinoblastoma (pRB) and histone-modifying complexes, repressing promoters of specific genes [58]. Röhl et al. [59] detected several genes, including ARID4A, overexpressed in astrocytes treated with medium conditioned by activated microglia, which protected them against stress conditions. Recently, Wu et al. [60] showed that Arid4a-deficient mice exhibit down-regulation of several homeobox genes and of the forkhead box gene Foxp3, which codes a transcription factor involved in the development and function of regulatory $\mathrm{T}$ cells [61]. These mice also show bone marrow failure with myelofibrosis and higher frequencies of hematologic malignancies, providing evidence that ARID $4 A$ functions as a tumor suppressor gene and its absence is permissive for the proliferation of connective tissue elements. The study of Perez et al. [62] added data on the role of this gene in cancer. These authors detected increased mRNA levels of $A R I D 4 A$ and RB1 in normal human epidermal keratinocytes treated with arsenic and benzo [a]pyrene in vitro. Since these chemicals alter proliferation and inhibit differentiation of keratinocytes [63-65], the findings may indicate that up-regulation of ARID4A is negatively related to epithelial differentiation. Therefore, the potential modulation of this gene by paracrine factors produced by stromal fibroblasts may represent an attempt to promote differentiation of neoplastic epithelial cells and, at the same time, their proliferation.

Calreticulin (coded by CALR or CRT gene) is a calcium-binding protein of the endoplasmic reticulum with intracellular and extracellular functions related to cellular adhesion, migration, and phagocytosis [66]. Calreticulin can be observed on the surface of stressed cells and, when bound to the plasma membrane of apoptotic cells, drives the phagocytosis by macrophages and dendritic cells [67]. In absence of this protein, the cells are not efficiently removed by phagocytes [68]. Recently, Nanney et al. [69] showed that calreticulin stimulates both migration and proliferation of keratinocytes and fibroblasts and apparently attracts monocytes and macrophages, suggesting its involvement in inflammatory response. Otherwise, fibroblasts underexpressing CARL exhibit weak adhesion and spreading [70]. Accordingly, Kypreou et al. [71] detected a correlation between calreticulin up-regulation and progression of fibrosis and also that TGF-beta, a contributing factor in fibrotic processes, up-regulated calreticulin in cultured human epithelial cells. In light of the data, we speculate that the low levels of this protein observed in treated Hep-2 cells inhibit proliferation, or represent a protective response of neoplastic cells to phagocytosis and antitumor immune process.

Guanine nucleotide binding protein ( $G$ protein), beta polypeptide 2-like 1 or Rack1 (coded by GNB2L1 gene) is a cytosolic protein homologous to the beta subunit of $\mathrm{G}$ proteins, and contains seven WD repeats, which act as sites for protein-protein interactions. Binding partners of GNB2L1 include protein kinase C, Src family kinases, components of the ERK pathway, cytokine and interferon receptors, beta integrins and many others. Many of these interactions are consistent with the participation of Rack1 in cell adhesion, movement and growth [72-75].

Sequestosome 1 or ubiquitin-binding protein p62 (coded by SQSTM1 or $p 60$ or $p 62$ gene) is a $62-\mathrm{kDa}$ protein that binds to the Src homology 2 (SH2) domain of $556^{\text {lck }}$ kinase in a phosphotyrosine-independent manner [76]. It has been suggested that p62 is a signaling adaptor which links different signal transduction pathways related to cell proliferation, differentiation and death, including NF- $\kappa \mathrm{B}$ pathway [77-82]. SQSTM1 abnormal expression has been observed in hepatocellular, prostate and breast cancers [83-85] and is associated with poor outcomes in breast cancer [86].

Another gene down-regulated by fibroblast-conditioned medium is USP9X (ubiquitin specific peptidase 9, $\mathrm{X}$-linked), also known as DFFRX, FAF or FAM. This gene is a member of the peptidase C19 family and encodes a protein similar to ubiquitin-specific proteases (USPs). These proteases regulate the production and recycling of ubiquitin and are critically involved in the control of cell growth, differentiation, and apoptosis [87]. Alteration of USPs may play an important role in the pathogenesis of cancer [88] and may exert distinct growth regulatory activities by acting as oncoproteins or 
tumor suppressor proteins. Overexpression of certain USPs correlates with progression towards a more malignant phenotype in carcinoma of lung, kidney, breast and prostate $[89,90]$.

RNF10 (ring finger protein 10) is the least known gene selected for validation. The product contains a ring finger motif, which is involved in protein-protein interactions and has been described in proteins implicated in many cellular processes such as signal transduction, transcriptional regulation, ubiquination, and apoptosis [91,92].

With respect to proteomic analysis, few differences (mostly quantitative) between treated and non-treated cells were detected. Among the proteins differentially expressed, alpha-enolase, heterogeneous nuclear ribonucleoprotein $\mathrm{C} \mathrm{C} 1 / \mathrm{C} 2$, aldolase $\mathrm{A}$, tubulin beta and glyceraldehyde-3-phosphate dehydrogenase were downregulated in neoplastic cells treated with FCM and vimentin and actin were down-regulated in fibroblasts treated with HCM. These proteins, produced by neoplastic cells or fibroblasts, may affect tumorigenesis. For example, the glycolytic enzyme alpha-enolase and its enzymatically inactive isoform MBP-1 (c-myc promoter binding protein 1) are negative regulators for $M Y C$ expression [93,94]. MYC is one of the most frequently de-regulated oncogenes in cancer [95] and, in the absence of both enzymes, may become activated and accelerate tumor growth. Contrary to $\mathrm{RaSH}$ results, alpha enolase protein was observed underexpressed by proteomic analysis in treated Hep- 2 cells, which may indicate a nonspecific finding or a post-transcriptional/ posttranslational regulation of the RNA/enzyme.

\section{Conclusions}

Fibroblasts, as other cells in tumor microenvironments, need to maintain close communication with cancer cells, promoting proliferation, recruitment of inflammatory cells and acquisition of invasive characteristics. Similarly, cancer cells may influence stromal cells to generate a favorable and supportive environment, which would supply them with nutrients and factors necessary for developing the tumor and spreading of metastasis. In the present study, we observed both positive and negative effects exerted by fibroblasts on Hep- 2 cells, favoring or not the former. A significant and common denominator in the results was the potential induction of signaling changes associated with immune or inflammatory response in the absence of a specific protein. In fact, ARID4A down-regulation is related to low levels of the transcript factor Foxp3 [60], which in turn is linked to immune responsiveness by targeting $\mathrm{NF}-\kappa \mathrm{B}$ and CREB pathways [96]. The final effect is the inhibition of the inflammatory response and the cost is a permissive sign for fibroblast proliferation [60]. Down-regulation of
$C A R L$ also blocks the inflammatory response but has negative effects on stroma growth [69]. In presence of low levels of Rack1, again a deficient or altered inflammatory response may occur since Rack 1 underexpression has already been related to the deregulation of cytokine production [97]. Similar results have been observed in p62-deficient mice, which exhibit abnormal control of NF- $\kappa$ B activation and reduced inflammation in experimental conditions [98]. The opposite effect is expected for osteoactivin underexpression because this protein has been observed as a negative regulator of macrophage inflammatory responses [99].

The complexity of the tumor microenvironment is immense and much information is still necessary for better understanding how the relationship between stroma and carcinoma cells can be used for diagnostic and prognostic evaluation and a target for therapy.

Additional file 1: Clinicopathological features of 24 patients with larynx SCC and of 23 patients with tongue SCC.

Additional file 2: Underexpressed proteins in Hep-2 cells and fibroblasts treated with conditioned medium from fibroblasts (FCM) and Hep-2 (HCM), respectively.

\section{Acknowledgements}

We acknowledge the financial support from Fundaçăo de Amparo à

Pesquisa do Estado de Săo Paulo/FAPESP (Grants 04/12054-9 and 06/601620), Rede Proteoma do Estado de São Paulo (Grant FAPESP 04/14846-0/FINEP 01.07.0290.00), The Ludwig Institute for Cancer Research, and the researcher fellowships from FAPESP (FCR-L) and Conselho Nacional de Pesquisas/CNPq (EHT, SMO).

The GENCAPO (Head and Neck Genome) Project authors are the following: Cury $\mathrm{PM}^{7}$, de Carvalho $\mathrm{MB}^{8}$, Dias-Neto $\mathrm{E}^{3,14}$. Fiqueiredo DLA ${ }^{9}$. Fukuyama $\mathrm{EE}^{5}$, Góis-Filho $\mathrm{JF}^{5}$, Leopoldino $\mathrm{AM}^{15}$, Mamede $\mathrm{ACM} \mathrm{M}^{9}$, Michaluart-Junior $\mathrm{P}^{6}$, Moyses RA ${ }^{6}$, Nóbrega $\mathrm{FG}^{4}$, Nóbrega MPP ${ }^{4}$, Nunes FD ${ }^{13}$, Ojopi EPB ${ }^{3}$, Serafin $\mathrm{LN}^{10}$, Severino $P^{1}$, Silva $A M A^{8}$, Silva Jr WA ${ }^{11}$, Silveira NJF $^{16}$, Souza SCOM $^{13}$ Tajara $\mathrm{EH}^{2}$, Wünsch-Filho $\mathrm{V}^{12}$, Amar $\mathrm{A}^{8}$, Bandeira $\mathrm{CM}^{4}$, Braconi $\mathrm{MA}^{4}$, Brandão $L^{6}$, Brandão $\mathrm{RM}^{11}$, Canto $\mathrm{AL}^{4}$, Cerione $\mathrm{M}^{5}$, Cicco $\mathrm{R}^{5}$, Chagas $\mathrm{M}^{4}$, Chedid $\mathrm{H}^{8}$, Costa $A^{12}$, Cunha $B R^{2}$, Curioni $O A^{8}$, Fortes $C S^{12}$, Franzi $S A^{8}$, Frizzera $A P Z^{7}$, Gazito $D^{8}$, Guimarães PEM ${ }^{6}$, Kaneto $\mathrm{CM}^{11}$, López RVM ${ }^{12}$, Macarenco $\mathrm{R}^{4}$, Magalhães $\mathrm{MR}^{8}$, Meneses $\mathrm{C}^{4}$, Mercante $\mathrm{AMC}^{8}$, Pinheiro $\mathrm{DG}^{11}$, Polachini $\mathrm{GM}^{2}$, Rapoport $A^{8}$, Rodini $C O^{13}$, Rodrigues-Lisoni $F^{2}{ }^{2}$, Rodrigues $R^{\prime} V^{2}$, Rossi $L^{8}$, Santos ARD ${ }^{11}$, Santos $M^{8}$, Settani $F^{5}$, Silva FAM ${ }^{15}$, Silva $\Pi^{11}$, Souza TB $^{8}$, Stabenow $E^{6}$. Takamori $J^{8}$, Valentim $P f^{5}$, vidotto $A^{2}$, Xavier $F C A^{13}$ Yamagushi $\mathrm{F}^{5}$, Cominato $\mathrm{ML}^{5}$, Correa $\mathrm{PMS}^{4}$, Mendes $\mathrm{GS}^{5}$, Paiva $\mathrm{R}^{5}$, Ramos $\mathrm{O}^{6}$, Silva $C^{6}$, Silva $M^{5}$, Tarlá $M V C^{11}$ (also presented in http //dc.fmrp.usp.br/ clinicalgenomics/cp/group.asp).

Affiliations: Instituto de Ensino e Pesquisa Albert Finstein, Săo Paulo, 'Departamento de Biologia Molecular, Faculdade de Medicina de Săo José do Rio Preto; ${ }^{3}$ Departamento e Instituto de Psiquiatria, Faculdade de Medicina, Universidade de São Paulo (USP), São Paulo; ${ }^{4}$ Departamento de Biociências e Diagnóstico Bucal, Faculdade de Odontologia, Universidade Estadual Paulista, São José dos Campos, São Paulo, ${ }^{5}$ Serviço de Cirurgia de Cabeça e Pescoço, Instituto do Cåncer Arnaldo Vieira de Carvalho, Săo Paulo; ${ }^{6}$ Departamento de Cirurgia de Cabeca e Pescoço, Faculdade de Medicina, USP, São Paulo; 'Departamento de Patologia, Faculdade de Medicina de São José do Rio Preto; ${ }^{8}$ Hospital Heliópolis, Săo Paulo; ${ }^{9}$ Serviço de Cirurgia de Cabeça e Pescoço, Faculdade de Medicina de Ribeirão Preto, USP: ${ }^{10}$ Departamento de Patologia, Faculdade de Medicina de Ribeirão Preto, USP; ${ }^{11}$ Departamento de Genética, Faculdade de Medicina de Ribeirão Preto, USP; ${ }^{12}$ Departamento de Epidemiologia, Faculdade de Saúde Pública, USP, Săo Paulo; ${ }^{13}$ Departamento de Estomatologia, Faculdade de Odontologia da 
USP, São Paulo; ${ }^{14}$ Centro de Pesquisas do Hospital AC Camargo. São Paulo, ${ }^{15}$ Departamento de Análises Clínicas, Toxicológicas e Bromatológicas, Faculdade de Ciências Farmacêuticas de Ribeirão Preto, USP;

${ }^{16}$ Departamento de Ciências Exatas, Universidade Federal de Alfenas, UNIFAL, MG: Brazil.

\section{Author details}

'Department of Molecular Biology, School of Medicine (FAMERP), São José do Rio Preto, Brazil. ${ }^{2}$ Department of Biology, Instituto de Biociências, Letras e Ciências Exatas (IBILCE), São Paulo State University (UNESP), São José do Rio Preto, Brazil. ${ }^{3}$ Department of Otorhinolaryngology and Head and Neck Surgery, School of Medicine (FAMERP), São José do Rio Preto, Brazil. "Department of Genetics and Evolutionary Biology, Institute of Biosciences, University of São Paulo (USP), São Paulo, Brazil. ${ }^{5}$ Department of Head and Neck Surgery, Amaldo Vieira de Carvalho Hospital, São Paulo, Brazil. ${ }^{6}$ Division of Head and Neck Surgery, Department of Surgery, School of Medicine (USP), São Paulo, Brazil. 'Department of Head and Neck Surgery, Heliópolis Hospital, São Paulo, Brazil. "Department of Biology and Zootechny, Faculty of Engineering of tha Solteria (UNESP), Itha Solteira, Brazil. ${ }^{9}$ Author list and addresses presented in the Acknowledgements.

\section{Authors' contributions}

FCR-L participated in the design of the study and analysis of the data, carried out cell culture, RaSH experiments and drafted the manuscript. PP Jr helped with RaSH experiments. AV and GMP carried out proteomics analysis. JVM was responsible for sample collection and processing. JC-R carried out cloning and sequencing of the samples. BRC carried out cell culture experiments. TH helped with manuscript preparation. CFS performed the real time PCR experiments. RAPT and SMO carried out immunofluorescence and immunohistochemical analysis. EEF and PMJr carried out clinical data analysis for sample selection. MBdC carried out clinical data analysis for sample selection and drafted the manuscript. GENCAPO team members were responsible for sample collection and initial on-site sample processing, provided the pathological analysis of the cases, obtained the informed consent and discussed the findings. EHT participated in the study design and coordination, carried out the analysis and interpretation of the data and drafted the manuscript. All authors read and approved the final manuscript.

\section{Competing interests}

The authors declare that they have no competing interests

Received: 26 June 2009 Accepted: 4 May 2010 Published: 4 May 2010

\section{References}

1. Kumar V FN, Abbas A: Robbins \& Cotran: Pathologic Basis of Disease Philadelphia: Saunders 2004

2. Dvorak HF: Tumors: wounds that do not heal. Similarities between tumor stroma generation and wound healing. N Engl J Med 1986, 315(26):1650-1659.

3. Tlsty TD, Hein PW: Know thy neighbor: stromal cells can contribute oncogenic signals. Curr Opin Genet Dev 2001, 11(1):54-59.

4. Li H, Fan X, Houghton J: Tumor microenvironment: the role of the tumor stroma in cancer. I Cell Biochem 2007, 101(4):805-815.

5. Zhao H, Ramos CF, Brooks JD, Peehl DM: Distinctive gene expression of prostatic stromal cells cultured from diseased versus normal tissues. $J$ Cell Physio/ 2007, 210(1):111-121

6. Finak $G$, Bertos $N$, Pepin $F$, Sadekova S, Souleimanova $M$, Zhao $H$, Chen $H$, Omeroglu G, Meterissian S, Omeroglu A, et al: Stromal gene expression predicts clinical outcome in breast cancer. Nat Med 2008, 14(5):518-527.

7. Ao M, Franco OE Park D, Raman D, Williams K, Hayward SW: Cross-talk between paracrine-acting cytokine and chemokine pathways promotes malignancy in benign human prostatic epithelium. Cancer Res 2007, 67(9):4244-4253.

8. Degen M, Brellier F, Kain R, Ruiz C, Terracciano L, Orend G, ChiquetEhrismann $R$ : Tenascin-W is a novel marker for activated tumor stroma in low-grade human breast cancer and influences cell behavior. Cancer Res 2007, 67(19):9169-9179.

9. Micke $P$, Ostman A: Tumour-stroma interaction: cancer-associated fibroblasts as novel targets in anti-cancer therapy? Lung Cancer 2004, 45(Suppl 2):S163-175.
10. Zalatnai A: Molecular aspects of stromal-parenchymal interactions in malignant neoplasms. Curr Mol Med 2006, 6(6):685-693.

11. Kobayashi R, Deavers M, Patenia R, Rice-Stitt T, Halbe J, Gallardo S, Freedman RS: 14-3-3 zeta protein secreted by tumor associated monocytes/macrophages from ascites of epithelial ovarian cance patients. Cancer Immunol Immunother 2009, 58(2):247-258.

12 Pietras K, Pahler J, Bergers G, Hanahan D: Functions of paracrine PDGF signaling in the proangiogenic tumor stroma revealed by pharmacological targeting. PLoS Med 2008, 5(1):e19.

13. Mueller MM, Fusenig NE: Friends or foes - bipolar effects of the tumour stroma in cancer. Nat Rev Cancer 2004, 4(11):839-849.

14. Quemener C, Gabison EE, Naimi B, Lescaille G, Bougatef F, Podgorniak MP, Labarchede G, Lebbe C, Calvo F, Menashi S, et al: Extracellular matrix metalloproteinase inducer up-regulates the urokinase-type plasminogen activator system promoting tumor cell invasion. Cancer Res 2007 67(1):9-15.

15. Albini A, Sporn MB: The tumour microenvironment as a target for chemoprevention. Nat Rev Cancer 2007, 7(2):139-147.

16. Maeda S, Omata M: Inflammation and cancer: role of nuclear factorkappaB activation. Cancer Sci 2008, 99(5):836-842.

17. Kuper H, Adami HO, Trichopoulos D: Infections as a major preventable cause of human cancer. $J$ Intern Med 2000, 248(3):171-183.

18. Rodrigues-Lisoni FC, Mehet DK, Peitl P Jr, John CD, da Silva Junior WA Tajara E, Buckingham JC, Solito E: In vitro and in vivo studies on CCR10 regulation by Annexin A1. FEBS Lett 2006, 580(5):1431-1438.

19. Silistino-Souza R, Rodrigues-Lisoni FC, Cury PM, Maniglia JV, Raposo LS, Tajara EH, Christian HC, Oliani SM: Annexin 1: differential expression in tumor and mast cells in human larynx cancer. Int J Cancer 2007. 120(12):2582-2589.

20. Alves VA, Nonogaki S, Cury PM, Wunsch-Filho V, de Carvalho MB, Michaluart-Junior P, Moyses RA, Curioni OA, Figueiredo DL, ScapulatempoNeto C, et al: Annexin A1 subcellular expression in laryngeal squamous cell carcinoma. Histopathology 2008, 53(6):715-727.

21. Allavena P, Garlanda C, Borrello MG, Sica A, Mantovani A: Pathways connecting inflammation and cancer. Curr Opin Genet Dev 2008, 18(1):3-10.

22 Olumi AF, Grossfeld GD, Hayward SW, Carroll PR, Tlsty TD, Cunha GR: Carcinoma-associated fibroblasts direct tumor progression of initiated human prostatic epithelium. Cancer Res 1999, 59(19):5002-5011.

23. Orimo A, Weinberg RA: Stromal fibroblasts in cancer. a novel tumorpromoting cell type. Cell Cyde 2006, 5(15):1597-1601.

24. Elenbaas B, Weinberg RA: Heterotypic signaling between epithelial tumor cells and fibroblasts in carcinoma formation. Exp Cell Res 2001, 264(1):169-184

25. Hawsawi NM, Ghebeh $\mathrm{H}$, Hendrayani SF, Tulbah A, Al-Eid M, Al-Tweigeri T, Ajarim D, Alaiya A, Dermime S, Aboussekhra A: Breast carcinomaassociated fibroblasts and their counterparts display neoplastic-specific changes. Cancer Res 2008, 68(8):2717-2725.

26. Chang HY, Chi JT, Dudoit S, Bondre C, Rijn van de M, Botstein D, Brown PO: Diversity, topographic differentiation, and positional memory in human fibroblasts. Proc Natl Acad Sci USA 2002, 99(20):12877-12882

27. Kalluri R, Zeisberg M: Fibroblasts in cancer. Nat Rev Cancer 2006, 6(5):392-401.

28. Eyden B: The myofibroblast: phenotypic characterization as a prerequisite to understanding its functions in translational medicine. $J$ Cell Mol Med 2008, 12(1):22-37.

29. Fukumura D, Xavier R, Sugiura T, Chen Y, Park EC, Lu N, Selig M, Nielsen G, Taksir $\mathrm{T}$, Jain RK, et al: Tumor induction of VEGF promoter activity in stromal cells. Cell 1998, 94(6):715-725,

30. Sternlicht MD, Lochter A, Sympson CJ, Huey B, Rougier JP, Gray JW, Pinkel D, Bissell MJ, Werb Z: The stromal proteinase MMP3/stromelysin-1 promotes mammary carcinogenesis. Cell 1999, 98(2):137-146.

31. Mueller L, Goumas FA, Affeldt M, Sandtner S, Gehling UM, Brilloff S, Walter J, Karnatz N, Lamszus K, Rogiers X, et al: Stromal fibroblasts in colorectal liver metastases originate from resident fibroblasts and generate an inflammatory microenvironment. Am J Pathol 2007. 171(5):1608-1618

32 Bair EL, Massey CP, Tran NL, Borchers AH, Heimark RL, Cress AE, Bowden GT: Integrin- and cadherin-mediated induction of the matrix metalloprotease matrilysin in cocultures of malignant oral squamous cell carcinoma cells and dermal fibroblasts. Exp Cell Res 2001, 270(2):259-267. 
33. Ikebe T, Nakayama H, Shinohara M, Shirasuna K: NF-kappaB involvement in tumor-stroma interaction of squamous cell carcinoma. Oral Oncol 2004 , 40(10):1048-1056

34. Che ZM, Jung TH, Choi JH, Yoon do J, Jeong HJ, Lee EJ, Kim J: Collagenbased co-culture for invasive study on cancer cells-fibroblasts interaction. Biochem Biophys Res Commun 2006, 346(1):268-275.

35. Zhang W, Matrisian LM, Holmbeck K, Vick CC, Rosenthal EL: Fibroblastderived MT1-MMP promotes tumor progression in vitro and in vivo. BMC Cancer 2006, 6:52

36. Kenny PA, Lee GY, Bissell M: Targeting the tumor microenvironment. Front Biosd 2007, 12:3468-3474.

37. Suresh S: Biomechanics and biophysics of cancer cells. Acta Biomater 2007, 3(4):413-438

38. Halsted KC, Bowen KB, Bond L, Luman SE, Jorcyk CL, Fyffe WE, Kronz JD, Oxford J: Collagen alpha1(XI) in normal and malignant breast tissue. Mad Patho/ 2008, 21(10):1246-1254.

39. Gough MJ, Ruby CE, Redmond WL, Dhungel B, Brown A, Weinberg AD: OX40 agonist therapy enhances CD8 infiltration and decreases immune suppression in the tumor. Cancer Res 2008, 68(13):5206-5215.

40. Schneider BP, Sledge GW Jr: Drug insight: VEGF as a therapeutic target for breast cancer. Nat Clin Pract Oncol 2007, 4(3):181-189.

41. Gettinger S: Targeted therapy in advanced non-small-cell lung cancer. Semin Respir Crit Care Med 2008, 29(3):291-301.

42. Aidinis V, Carninci P, Armaka M, Witke W, Harokopos V, Pavelka N, Koczan D, Argyropoulos C, Thwin MM, Moller S, et at. Cytoskeletal rearrangements in synovial fibroblasts as a novel pathophysiological determinant of modeled rheumatoid arthritis. PLOS Genet 2005, 1(4):e48.

43. Chen TR, Shaw MW: Stable chromosome changes in human malignant melanoma. Cancer Res 1973, 33(9):2042-2047.

44. Miyamoto M, Sugawa H, Mori T, Hase K, Kuma K, Imura H: Epidermal growth factor receptors on cultured neoplastic human thyroid cells and effects of epidermal growth factor and thyroid-stimulating hormone on their growth. Cancer Res 1988, 48(13):3652-3656.

45. Solito E, Kamal A, Russo-Marie F, Buckingham JC, Marullo S, Perretti M: A novel calcium-dependent proapoptotic effect of annexin 1 on human neutrophils. FASEB J 2003, 17(11):1544-1546

46. Jiang $H$, Kang DC, Alexandre D, Fisher PB: RaSH, a rapid subtraction hybridization approach for identifying and cloning differentially expressed genes. Proc Natl Acad Sci USA 2000 97(23):12684-12689.

47. Sambrook J, Russel DW: Molecular Cloning: a laboratory manual Cold Spring Harbor, N.Y.: Cold Spring Harbor Laboratory Press, 32001

48. BLAST. [http//www.ncbi.nlm.nih.gov/BLAST/]

49. GeneOntology. [http://www.geneontology.org]

50. Pfaffl MW: A new mathematical model for relative quantification in realtime RT-PCR. Nucleic Acids Res 2001, 29(9):e45.

51. de Marqui $A B$, Vidotto A, Polachini GM, Bellato Cde M, Cabral $H$ Leopoldino AM, de Gois Filho JF, Fukuyama EE, Settanni FA, Cury PM, et a: Solubilization of proteins from human lymph node tissue and twodimensional gel storage. J Biochem Mol Biol 2006, 39(2):216-222.

52. MASCOT. [http:/wwww.matrixscience.com/cgi/search_form.pl? FORMVER $=2 \&$ SEARCH $=$ MIS]

53. UniProtKB/Swiss-Prot. [http//ca.expasy.org/sprot/]

54. Ohtani H: Pathophysiologic significance of host reactions in human cancer tissue: desmoplasia and tumor immunity. Tohoku J Exp Med 1999, 187(3):193-202.

55. De Wever O, Mareel M: Role of tissue stroma in cancer cell invasion. Pathol 2003, 200(4):429-447.

56. Sis B, Sarioglu S, Sokmen S, Sakar M, Kupelioglu A, Fuzun M: Desmoplasia measured by computer assisted image analysis: an independent prognostic marker in colorectal carcinoma. J Clin Pathol 2005, 58(1):32-38

57. Olsen KD, Caruso M, Foote RL, Stanley RJ, Lewis JE, Buskirk SJ, Frassica DA DeSanto LW, O'Fallon WM, Hoverman VR: Primary head and neck cancer. Histopathologic predictors of recurrence after neck dissection in patients with lymph node involvement. Arch Otolaryngol Head Neck Surg 1994, 120(12):1370-1374.

58. Hurst DR, Xie $Y$, Vaidya KS, Mehta A, Moore BP, Accavitti-Loper MA Samant RS, Saxena R, Silveira AC, Welch DR: Alterations of BRMS1-ARID4A interaction modify gene expression but still suppress metastasis in human breast cancer cells. J Biol Chem 2008, 283(12):7438-7444

59. Rohl C, Armbrust E, Kolbe K, Lucius R, Maser E, Venz S, Gulden M: Activated microglia modulate astroglial enzymes involved in oxidative and inflammatory stress and increase the resistance of astrocytes to oxidative stress in Vitro. Glia 2008, 56(10):1114-1126

60. Wu MY, Eldin KW, Beaudet AL: Identification of chromatin remodeling genes Arid4a and Arid4b as leukemia suppressor genes. I Natl Cancer Inst 2008, 100(17):1247-1259.

61. Zheng Y, Rudensky AY: Foxp3 in control of the regulatory $T$ cell lineage. Nat Immunol 2007, 8(5):457-462

62. Perez DS, Handa RJ, Yang RS, Campain JA: Gene expression changes associated with altered growth and differentiation in benzo[a]pyrene or arsenic exposed normal human epidermal keratinocytes. $J$ Appl Toxicol 2008, 28(4):491-508.

63. Perez DS, Armstrong-Lea L, Fox MH, Yang RS, Campain JA: Arsenic and benzo[a]pyrene differentially alter the capacity for differentiation and growth properties of primary human epidermal keratinocytes. Toxicol Sc 2003, 76(2):280-290.

64. Reznikova TV, Phillips MA, Rice RH: Arsenite suppresses Notch1 signaling in human keratinocytes. J Invest Dermatol 2009, 129(1):155-161.

65. Tse WP, Cheng $\mathrm{CH}$, Che CT, Lin ZX: Arsenic trioxide, arsenic pentoxide, and arsenic iodide inhibit human keratinocyte proliferation through the induction of apoptosis. J Pharmacol Exp Ther 2008, 326(2):388-394.

66. Johnson S, Michalak M, Opas M, Eggleton P: The ins and outs of calreticulin: from the ER lumen to the extracellular space. Trends Cell Bio 2001, 11(3):122-129.

67. Obeid M, Tesniere A, Ghiringhelli F, Fimia GM, Apetoh L, Perfettini JL, Castedo M, Mignot $\mathrm{G}$, Panaretakis T, Casares N, et al. Calreticulin exposure dictates the immunogenicity of cancer cell death. Nat Med 2007, 13(1):54-61.

68. Gardai SJ, Bratton DL, Ogden CA, Henson PM: Recognition ligands on apoptotic cells: a perspective. J Leukoc Biol 2006, 79(5):896-903.

69. Nanney LB, Woodrell CD, Greives MR, Cardwell NL, Pollins AC, Bancroft TA Chesser A, Michalak M, Rahman M, Siebert JW, et al: Calreticulin enhances porcine wound repair by diverse biological effects. Am J Pathol 2008 , 173(3):610-630

70. Szabo E, Papp S, Opas M: Differential calreticulin expression affects focal contacts via the calmodulin/CaMK II pathway. J Cell Physiol 2007, 213(1):269-277.

71. Kypreou KP, Kawadas P, Karamessinis P, Peroulis M, Alberti A, Sideras P, Psarras S, Capetanaki Y, Politis PK, Charonis AS: Altered expression of calreticulin during the development of fibrosis. Proteomics 2008, 8(12):2407-2419.

72 Vomastek T, Iwanicki MP, Schaeffer HJ, Tarcsafalvi A, Parsons JT, Weber MJ: RACK1 targets the extracellular signal-regulated kinase/mitogenactivated protein kinase pathway to link integrin engagement with focal adhesion disassembly and cell motility. Mol Cell Biol 2007 27(23):8296-8305.

73. McCahill A, Warwicker J, Bolger GB, Houslay MD, Yarwood SJ: The RACK scaffold protein: a dynamic $\operatorname{cog}$ in cell response mechanisms. Mol Pharmacol 2002, 62(6):1261-1273.

74. Doan AT, Huttenlocher A: RACK1 regulates Src activity and modulates paxillin dynamics during cell migration. Exp Cell Res 2007, 313(12):2667-2679

75. Mamidipudi V, Dhillon NK, Parman T, Miller LD, Lee KC, Cartwright CA: RACK1 inhibits colonic cell growth by regulating Src activity at cell cycle checkpoints. Oncogene 2007, 26(20):2914-2924.

76. Joung I, Strominger JL, Shin J: Molecular cloning of a phosphotyrosineindependent ligand of the p56lck SH2 domain. Proc Natl Acad Sci USA 1996, 93(12):5991-5995.

77. Duran A, Linares JF, Galvez AS, Wikenheiser K, Flores JM, Diaz-Meco MT, Moscat J: The signaling adaptor p62 is an important NF-kappaB mediator in tumorigenesis. Cancer Cell 2008, 13(4):343-354.

78. Sanz L, Sanchez P, Lallena MJ, Diaz-Meco MT, Moscat J: The interaction of p62 with RIP links the atypical PKCs to NF-kappaB activation. EMBO 1999, 18(11):3044-3053

79. Sanz L, Diaz-Meco MT, Nakano H, Moscat J: The atypical PKC-interacting protein p62 channels NF-kappaB activation by the IL-1-TRAF6 pathway. EMBO J 2000, 19(7):1576-1586.

80. Wooten MW, Seibenhener ML, Mamidipudi V, Diaz-Meco MT, Barker PA Moscat J: The atypical protein kinase $\mathrm{C}$-interacting protein $\mathrm{p} 62$ is a scaffold for NF-kappaB activation by nerve growth factor. $J$ Biol Chem 2001, 276(11):7709-7712 
81. Mamidipudi V, Li X, Wooten MW: Identification of interleukin 1 receptorassociated kinase as a conserved component in the p75-neurotrophin receptor activation of nuclear factor-kappa B. J Biol Chem 2002, 277(31):28010-28018

82. Chang S, Kim JH, Shin J: p62 forms a temary complex with PKCzeta and PAR-4 and antagonizes PAR-4-induced PKCzeta inhibition. FEBS Lett 2002, 510(1-2):57-61.

83. Stumptner $\mathrm{C}$, Heid $\mathrm{H}$, Fuchsbichler $\mathrm{A}$, Hauser $\mathrm{H}$, Mischinger $\mathrm{HJ}$, Zatloukal $\mathrm{K}$ Denk H: Analysis of intracytoplasmic hyaline bodies in a hepatocellular carcinoma. Demonstration of p62 as major constituent. Am J Pathol 1999, 154(6):1701-1710

84. Thompson HG, Harris JW, Wold BJ, Lin F, Brody JP: p62 overexpression in breast tumors and regulation by prostate-derived Ets factor in breast cancer cells. Oncogene 2003, 22(15):2322-2333.

85. Kitamura $\mathrm{H}$, Torigoe T, Asanuma H, Hisasue SI, Suzuki K, Tsukamoto T, Satoh M, Sato N: Cytosolic overexpression of p62 sequestosome 1 in neoplastic prostate tissue. Histopathology 2006, 48(2):157-161.

86. Rolland P, Madjd Z, Durrant L, Ellis $1 \mathrm{O}$, Layfield R, Spendlove I: The ubiquitin-binding protein p62 is expressed in breast cancers showing features of aggressive disease. Endocr Relat Cancer 2007, 14(1):73-80.

87. Rolen U, Kobzeva V, Gasparjan N, Ovaa H, Winberg G, Kisseljov F, Masucci MG: Activity profiling of deubiquitinating enzymes in cervical carcinoma biopsies and cell lines. Mol Carcinog 2006, 45(4):260-269.

88. Dees EC, Orlowski RZ: Targeting the ubiquitin-proteasome pathway in breast cancer therapy. Future Oncol 2006, 2(1):121-135.

89. Ovaa H, Kessler BM, Rolen U, Galardy PJ, Ploegh HL, Masucci MG: Activitybased ubiquitin-specific protease (USP) profiling of virus-infected and malignant human cells. Proc Natl Acad Sci USA 2004, 101(8):2253-2258.

90. Deng $\mathrm{S}$, Zhou $\mathrm{H}$, Xiong $\mathrm{R}$, Lu Y, Yan D, Xing T, Dong L, Tang E, Yang $\mathrm{H}$ : Over-expression of genes and proteins of ubiquitin specific peptidases (USPs) and proteasome subunits (PSs) in breast cancer tissue observed by the methods of RFDD-PCR and proteomics. Breast Cancer Res Treat 2007, 104(1):21-30

91. Borden KL: RING domains: master builders of molecular scaffolds? J Mol Biol 2000, 295(5):1103-1112

92. Freemont PS: RING for destruction? Curr Biol 2000, 10(2):R84-87

93. Spencer CA, Groudine M: Control of c-myc regulation in normal and neoplastic cells. Adv Cancer Res 1991, 56:1-48.

94. Subramanian A, Miller DM: Structural analysis of alpha-enolase. Mapping the functional domains involved in down-regulation of the c-myc protooncogene. J Biol Chem 2000, 275(8):5958-5965.

95. Prochownik EV: c-Myc: linking transformation and genomic instability. Curr Mol Med 2008, 8(6):446-458.

96. Grant C, Oh U, Fugo K, Takenouchi N, Griffith C, Yao K, Newhook TE, Ratner $L$, Jacobson $S$ : Foxp3 represses retroviral transcription by targeting both NF-kappaB and CREB pathways. PLoS Pathog 2006, 2(4):e33.

97. Racchi M, Sinforiani E, Govoni S, Marinovich M, Galli CL, Corsini E: RACK-1 expression and cytokine production in leukocytes obtained from $A D$ patients. Aging Clin Exp Res 2006, 18(2):153-157.

98. Moscat J, Diaz-Meco MT, Wooten MW: Signal integration and diversification through the p62 scaffold protein. Trends Biochem So 2007, 32(2):95-100

99. Ripoll VM, Irvine KM, Ravasi T, Sweet MJ, Hume DA: Gpnmb is induced in macrophages by IFN-gamma and lipopolysaccharide and acts as a feedback regulator of proinflammatory responses. J Immunol 2007, 178(10):6557-6566.

Pre-publication history

The pre-publication history for this paper can be accessed here http//www.biomedcentral.com/1755-8794/3/14/prepub

doi:10.1186/1755-8794-3-14

Cite this article as: Rodrigues-Lisoni et al: Genomics and proteomics approaches to the study of cancer-stroma interactions. BMC Medical Genomics 2010 3:14

\section{Submit your next manuscript to BioMed Central} and take full advantage of:

- Convenient online submission

- Thorough peer review

- No space constraints or color figure charges

- Immediate publication on acceptance

- Inclusion in PubMed, CAS, Scopus and Google Scholar

- Research which is freely available for redistribution
( Biomed Central 